U.S. GEOLOGICAL SURVEY CIRCULAR 1058

\title{
Metalliferous Black Shales and Related Ore Deposits- Proceedings, 1989 United States Working Group Meeting, International Geological Correlation Program Project 254
}




\section{AVAILABILITY OF BOOKS AND MAPS OF THE U.S. GEOLOGICAL SURVEY}

Instructions on ordering publications of the U.S. Geological Survey, along with prices of the last offerings, are given in the current-year issues of the monthly catalog "New Publications of the U.S. Geological Survey." Prices of available U.S. Geological Survey publications released prior to the current year are listed in the most recent annual "Price and Availability List." Publications that are listed in various U.S. Geological Survey catalogs (see back inside cover) but not listed in the most recent annual "Price and Availability List" are no longer available.

Prices of reports released to the open files are given in the listing "U.S. Geological Survey Open-File Reports," updated monthly, which is for sale in microfiche from the U.S. Geological Survey, Books and Open-File Reports Section, Federal Center, Box 25425, Denver, CO 80225. Reports released through the NTIS may be obtained by writing to the National Technical Information Service, U.S. Department of Commerce, Springfield, VA 22161; please include NTIS report number with inquiry.

Order U.S. Geological Survey publications by mail or over the counter from the offices given below.

\section{BY MAIL}

\section{Books}

Professional Papers, Bulletins, Water-Supply Papers, Techniques of Water-Resources Investigations, Circulars, publications of general interest (such as leaflets, pamphlets, booklets), single copies of Earthquakes \& Volcanoes, Preliminary Determination of Epicenters, and some miscellaneous reports, including some of the foregoing series that have gone out of print at the Superintendent of Documents, are obtainable by mail from

\section{U.S. Geological Survey, Books and Open-File Reports Federal Center, Box 25425 Denver, CO 80225}

Subscriptions to periodicals (Earthquakes \& Volcanoes and Preliminary Determination of Epicenters) can be obtained ONLY from the

\section{Superintendent of Documents \\ Government Printing Office \\ Washington, D.C. 20402} ments.)

(Check or money order must be payable to Superintendent of Docu-

\section{Maps}

For maps, address mail orders to

\section{U.S. Geological Survey, Map Distribution Federal Center, Box 25286 \\ Denver, CO 80225}

Residents of Alaska may order maps from

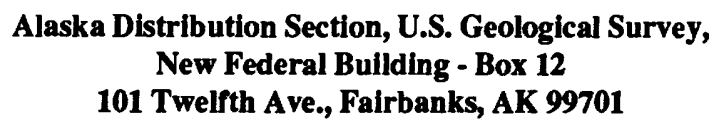

\section{OVER THE COUNTER}

\section{Books}

Books of the U.S. Geological Survey are available over the counter at the following Geological Survey Public Inquiries Offices, all of which are authorized agents of the Superintendent of Documents:

- WASHINGTON, D.C.--Main Interior Bldg., 2600 corridor, 18 th and C Sts., NW.

- DENVER, Colorado--Federal Bldg., Rm. 169, 1961 Stout St.

- LOS ANGELES, California--Federal Eldg., Rm. 7638, 300 N. Los Angeles St.

- MENLO PARK, California--Bldg. 3 (Stop 533), Rm. 3128, 345 Middlefield Rd.

- RESTON, Virginia--503 National Center, Rm. 1C402, 12201

Sunrise Valley Dr.

- SALT LAKE CITY, Utah--Federal Bldg., Rm. 8105, 125 South State St.

- SAN FRANCISCO, California--Customhouse, Rm. 504, 555

Battery St.

- SPOKANE, Washington--U.S. Courthouse, Rm. 678, West 920 Riverside Ave..

- ANCHORAGE, Alaska--Rm. 101, 4230 University Dr.

- ANCHORAGE, Alaska--Federal Bldg, Rm. E-146, 701 C St.

\section{Maps}

Maps may be purchased over the counter at the U.S. Geological Survey offices where books are sold (all addresses in above list) and at the following Geological Survey offices:

- ROLLA, Missouri-1400 Independence Rd.

- DENVER, Colorado--Map Distribution, Bldg. 810, Federal Center

- FAIRBANKS, Alaska--New Federal Bldg., 101 Twelfth Ave. 
Metalliferous Black Shales and Related Ore Deposits Proceedings, 1989 United States Working Group Meeting, International Geological Correlation Program Project 254 


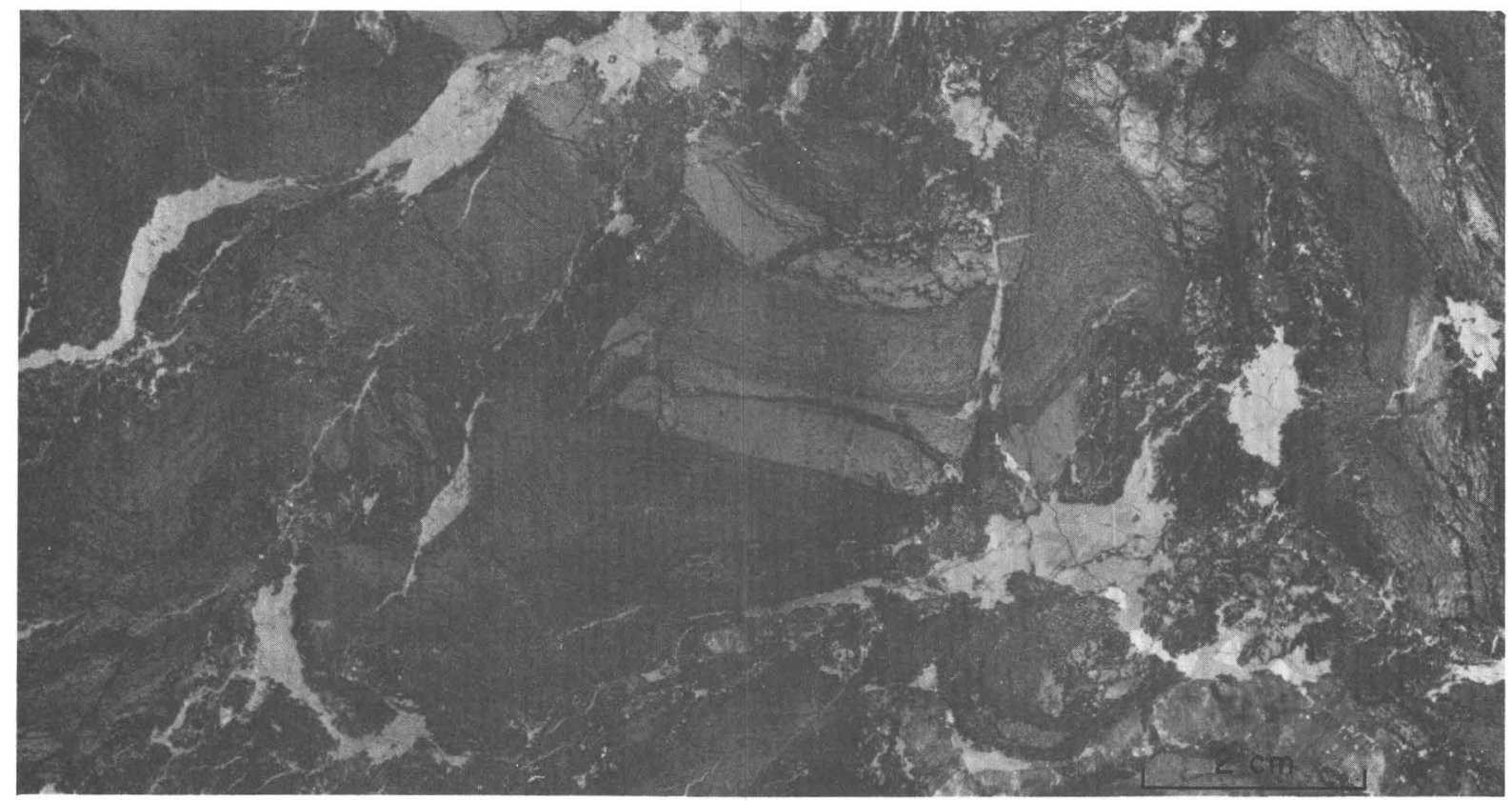

Frontispiece: Nickel-copper-zinc-mineralized, Proterozoic $(1.96-2.00 \mathrm{Ga})$ black shales, Talvivaara prospect, Finland. Photograph by Kirsti Loukola-Ruskeeniemi, Geological Survey of Finland. 
Metalliferous Black Shales and

Related Ore Deposits-

Proceedings, 1989 United States

Working Group Meeting,

International Geological Correlation

Program Project 254

Edited by RICHARD I. GRAUCH and HOLLY L.O. HUYCK 


\title{
U.S. DEPARTMENT OF THE INTERIOR
}

\author{
MANUEL LUJAN, JR., Secretary
}

\author{
U.S. GEOLOGICAL SURVEY
}

Dallas L. Peck, Director

Any use of trade, product, or firm names in this publication is for descriptive purposes only and does not imply endorsement by the U.S. Government.

Organizing committee for the 1989 meeting of the International Geological Correlation Program-Project 254 United States Working Group, Holly L.O.

Huyck, Chairwoman

UNITED STATES GOVERNMENT PRINTING OFFICE: 1990

Free on application to

Books and Open-File Reports Section

U.S. Geological Survey

Federal Center

Box 25425

Denver, CO 80225

\section{Library of Congress Cataloging-in-Publication Data}

Metalliferous black shales and related ore deposits_-Proceedings, ; 1989 United States Working Group meeting, International Geological Correlation Program Project 254 / edited by Richard I. Grauch and Holly L.O. Huyck.

p. cm.-(U.S. Geological Survey circular : 1058)

Includes bibliographical references.

Supt. of Docs. no.: I 19.4/2:1085.

1. Shale-Congresses. 2. Ore deposits-Congresses. I. Grauch, Richard I.

II. Huyck, Holly L.O. III. International Geological Correlation Programme.

Project 254. United States Working Group. IV. Series.

TN948.S5M48

1991

$553.2^{\prime} 83-\mathrm{dc} 20$

90-20610 


\title{
FOREWORD
}

\author{
Richard I. Grauch, Leader, U.S. Working Group, \\ International Geological Correlation Program Project 254 \\ Vice-Leader, International Geological Correlation Program Project 254
}

The papers and extended abstracts of this circular are summaries of most of the papers presented at the November 4, 1989, meeting of the U.S. Working Group of the International Geological Correlation Program's Project 254, Metalliferous Black Shales and Related Ore Deposits.

The International Geological Correlation Program (IGCP) has two principal objectives. The "primary goal is to encourage and facilitate geological research on a global scale, and to foster international cooperation. Current research stresses the nature and timing of major geologic events, the distribution and genesis of mineral and energy resources, and geological hazards" (B.J. Skinner and C.L. Drake, 1987, An unacclaimed success story: Geotimes, v. 32, no. 4, p. 11). "A secondary objective of many IGCP projects is to improve the geological capability and knowledge in developing countries" (U.S. National Committee for International Geological Correlation Program, 1988, The International Geological Correlation Prograrn, Newsletter 8, p. i). The IGCP is a joint functionary of the International Union of Geological Sciences (IUGS) and the United Nations Educational, Scientific, and Cultural Organization (UNESCO). It is guided by an advisory scientific committee and by a 15 -member board of scientists who are jointly appointed by IUGS and UNESCO. Most of the 90 participating nations have appointed national committees to coordinate the activities of the various national working groups that are associated with individual IGCP projects.

IGCP Project 254 was initiated by Jan Pasava of the Geological Survey, Prague, Czechoslovakia. Its primary, very ambitious, goals are (1) to compile and correlate data regarding metalliferous black-shale formations and related ore deposits, (2) to evaluate the role of depositional, diagenetic, volcanic, magmatic, metamorphic, and tectonic processes in the origin of metalliferous black shales and related ore deposits, (3) to investigate the roles of organic matter and sulfide in mineralization processes, and (4) to develop exploration criteria for ore deposits in black-shale formations.

The leadership of the project is as follows:

Leader: J. Pasava, Czechoslovakia

Vice-Leaders: $\quad$ R.I. Grauch, U.S.A.

V.A. Buryak, U.S.S.R.

Secretary: $\quad$ B.Buchardt, Denmark

Treasurer: $\quad$ Z. Gabriel, Czechoslovakia

Executive Board: I.R. Plimer, Australia

I.R. Jonasson, Canada

B. Kribek, Czechoslovakia

M. Pulec, Czechoslovakia

K. Ruskeeniemi, Finland

M. Pagel, France

B. Stribrny, Federal Republic of Germany

H. Dill, Federal Republic of Germany

R.C. Mehrotra, India

F. El Salem, Jordan 


\author{
A. Tijani, Morocco \\ M. Banas, Poland \\ L. Moshen, Tunis \\ V. Petrov, U.S.S.R. \\ S. Rodriguez, Venezuela \\ N. Shaffer, U.S.A. \\ Fan Delian, People's Republic of China
}

At the international level the project is divided into eight working groups: (1) $\mathrm{Au}$ and $\mathrm{Ag}$ mineralizations, (2) platinum-group element and $\mathrm{Cr}$ mineralizations, (3) $\mathrm{U}, \mathrm{Mo}$, and $\mathrm{V}$ mineralizations, (4) $\mathrm{Pb}, \mathrm{Zn}, \mathrm{Cu}$, and barite mineralizations, (5) Cu mineralizations, (6) $\mathrm{Sn}$, $\mathrm{W}, \mathrm{Hg}$, and $\mathrm{Sb}$ mineralizations, (7) $\mathrm{Mn}$ and $\mathrm{Fe}$ mineralizations, and (8) international standards and correlation of analytical measurements. Additionally, most of the 25 participating nations have formed multidisciplinary national working groups that have their own leaders and are expected to meet annually. These national working groups are generally loosely structured, and the individual participants are probably more closely aligned with the topical international working groups described above.

The diverse interests of the approximately 70 members (listed near the end of this circular) of the U.S. working group are well represented by the wide-ranging research topics presented at this meeting. We are excited about this new forum for communication and the synergism gained through international, multidisciplinary contacts. In addition, we have the ability (funded through the U.S. National Committee for IGCP) to assist in defraying the travel expenses of members who attend international project meetings and student members who attend national meetings. The meetings are open to all interested parties and the working group welcomes new members.

We thank the U.S. Geological Survey for publishing this circular.

International Meetings of International Geological Correlation Program Project 254

October, 1987 Jesenik, Czechoslovakia. Inaugural meeting.

July, 1988 Beijing, China. First international working session (in conjunction with the International Symposium on Sedimentalogy Related to Ore Deposits).

July, 1989 Washington, U.S.A. Second international working session (in conjunction with the International Geological Congress, Symposium C25).

August, 1990 Ottawa, Canada. Third international working session (in conjunction with the International Association on the Genesis of Ore Deposits Symposium).

November, 1990 Rabat, Morocco. International workshop and field conference (cosponsored by the Geological Society of Morocco).

August, 1991 Novosibirsk, U.S.S.R. International workshop and field conference, "Black shale basins and related mineral deposits" (cosponsored by the Siberian Branch of the Academy of Sciences of the U.S.S.R.). 


\section{CONTENTS}

Geochemistry of the Ordovician high-calcium black shales hosting major gold deposits of the Getchell trend in Nevada, by E.I. Floomstein and J.B. Clark 1

Geochemical control on the abundance of vanadium in black shales and related rocks, by George N. Breit, Richard B. Wanty, and Michele L. Tuttle 6

Nickel-molybdenum-platinum-gold deposits in black shales of southern China-A new ore type with possible analogs in Pennsylvanian rocks of the U.S.A., by Raymond M. Coveney, Jr., and Chen Nansheng 9

Geochemical and mineralogical comparison of the upper Pennsylvanian Stark Shale Member of the Dennis Limestone, east-central Kansas, with the Middle Pennsylvanian Mecca Quarry Shale Member of the Carbondale Formation in Illinois and of the Linton Formation in Indiana, ty G.A. Desborough, J.R. Hatch, and J.S. Leventhal 12

Organic ligands and metal-organic complexing in ore fluids of sedimentary origin, by Thomas H. Giordano 31

When is a metalliferous black shale not a black shale?, by Holly L.O. Huyck 42

Recent Black Sea sediments-Leg 4, 1988 l3lack Sea Expedition, by Timothy W. Lyons $\mathbf{5 7}$

Organic geochemical studies of metalliferous parts of the Middle Proterozoic Nonesuch Formation of northern Michigan, by Philip A. Meyers, Eileen S. Ho, and Jeffrey L. Mauk $\mathbf{5 9}$

Organic geochemical and petrological investigations of a natural reactor and its environs at Oklo, Gabon-A preliminary report, by Bartholomew Nagy, Joel S. Leventhal, and F. Gauthier-Lafaye: 65

Midcontinent Virgilian (Upper Pennsylvanian) black shales in eastern Kansas, by R.B. Schultz and J.B. Maynard 68

Membership of the U.S. Working Group of the International Geological Correlation Program Project $254 \quad 79$

Author index $\mathbf{8 5}$ 



\title{
Geochemistry of the Ordovician High-Calcium Black Shales Hosting Major Gold Deposits of the Getchell Trend in Nevada
}

\author{
By E.I. Bloomstein ${ }^{1}$ and J.B. Clark ${ }^{1}$
}

Deep-water marine black shales (generally metamorphosed to greenschist facies) host significant gold deposits worldwide, among them Bendigo in Australia, Muruntau and Sukhoi Log in the U.S.S.R., and Sucha Rudna in Czechoslovakia. In the Nevada gold province, auriferous Paleozoic black shales are part of a carbonate turbidite assemblage consisting of silty carbonaceous limestone and dolomite. Unfortunately, the black shales have not been identified as a separate unit within this assemblage. We believe that several gold deposits in the Osgood Mountains and other areas are associated with black shales. In particular, Ordovician black shales of the Comus Formation and carbonaceous phyllite of the Cambrian Preble Formation are hosts for the Getchell Trend gold deposits, namely Rabbit Creek, Getchell, and Pinson (fig. 1). Another example of a mineralized black shale is the Pilot Shale of Mississippian and Devonian age, which hosts the Alligator Ridge gold deposit (Ilchik and Brimhall, 1986). On the other hand, the black shales of the Devonian Woodruff Formation in north-central Nevada are not known to host gold deposits. The geochemical and mineralogical properties of black shales that make them favorable hosts for gold mineralization are still poorly understood.

Our presentation concerns the black shales and dolomite mudstones of the Comus Formation. In the area of the Rabbit Creek gold deposit (Bloomstein and others, in

Manuscript approved for publication, October 9, 1990.

${ }^{1}$ Santa Fe Pacific Mining Corporation, Box 27109, Albuquerque, New Mexico, 87125-7019. press), the shales are $150-250 \mathrm{~m}$ thick. Based upon rhythmic bedding, graded beds, and characteristic corodont fauna, they are interpreted to be quiescent deep-water shales deposited in an anoxic environment. The shalos are directly overlain by sparsely vesicular basalt flow's believed to have formed at seawater depths between 500 and $1,800 \mathrm{~m}$.

The unoxidized shales and mudstones consist of about 20 percent illite, 20 percent carbonate minerels (as aggregates and intraclasts of calcite and rhombohedral grains of dolomite), 40-45 percent detrital quartz., and 12-15 percent syngenetic pyrite as amorphous grains, framboids, and cubes. The organic carbon content of the shales of the Comus is generally 1-1.5 percent but may be as high as 5 percent. Organic matter is type I or II kerogen, marine algal in origin, as evidenced by large amounts of tricyclic terpane biomarkers and by high proportions of C27 and C28 sterane (Philp, 1985). Most of the organic carbon is overmature, having the rank of meta-anthracite; extractable bitumen in amounts of 30$80 \mathrm{ppm}$ is also present. Gas chromatography results show that the bitumen consists of short-chain and long-crain nalkanes. The presence of such immature material requires that bitumen migrated into the shales after the kerogen had thermally matured. All organic matter was introduced before the gold mineralization took place.

The shales of the Comus (table 1) are calcrreous (11.35 weight percent $\mathrm{CaO}$ ) and locally dolomitic (3.71 weight percent $\mathrm{MgO}$ ). True limestones are not present. The $\mathrm{TiO}_{2} / \mathrm{Al}_{2} \mathrm{O}_{3}$ ratio $(0.087)$ may indicate a slight mafic volcanic input into the clastic material (Spears and Kanaris-Sotirou, 1976). 


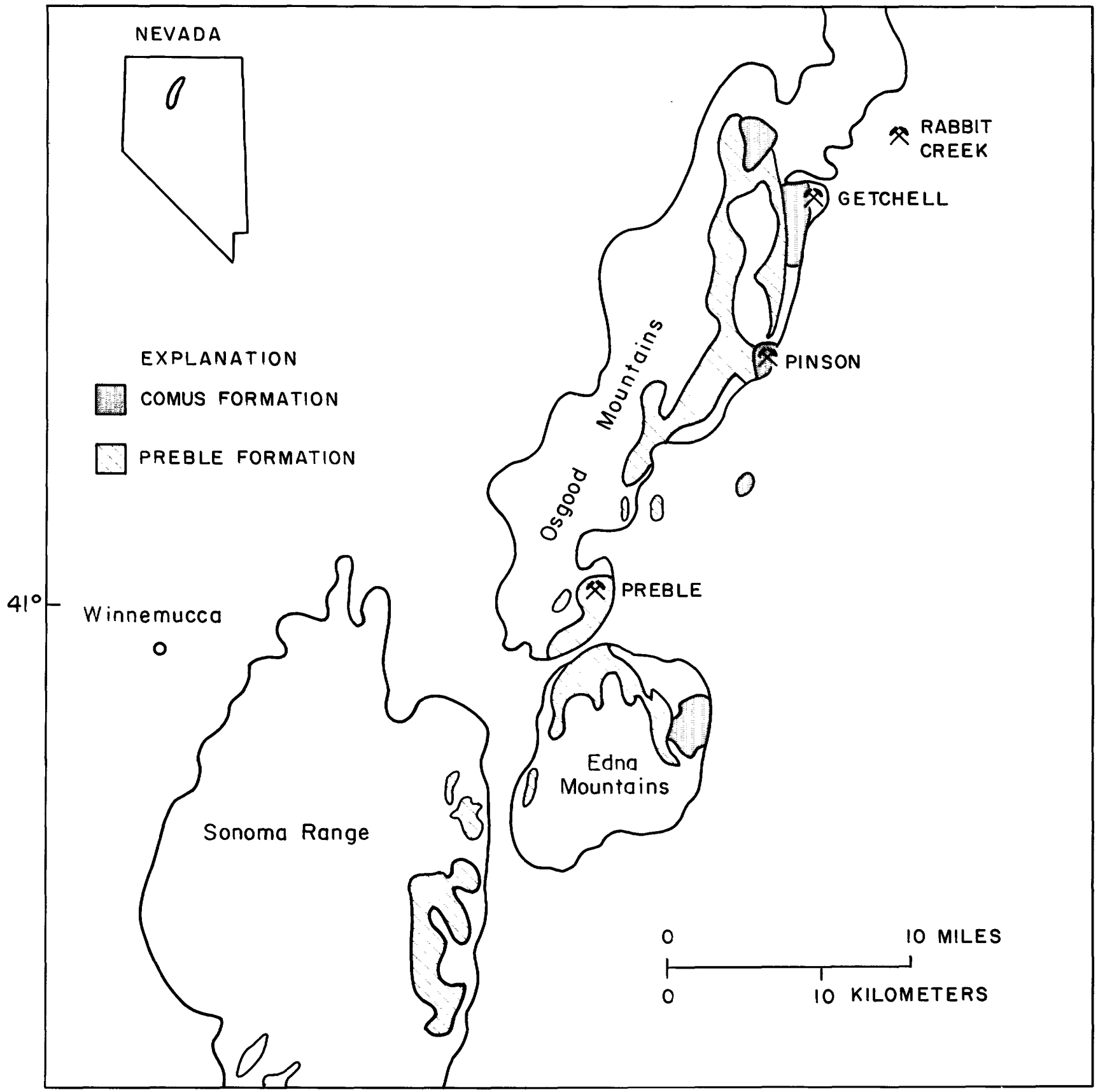

Figure 1. Location map of Comus and Preble Formation and associated gold mines in north-central Nevada.

Unmineralized samples of shales of the Comus were carefully selected to characterize the background geochemistry, but, because they are in close proximity to gold deposits, they may reflect a district-scale halo of mineralization. The shales of the Comus are enriched in $\mathrm{As}, \mathrm{Sb}, \mathrm{Hg}$, and $\mathrm{Ag}$ (table 2), having abundances at least twice those of USGS Standard SDO-1.

Hydrothermal alteration of the Comus black shales at Rabbit Creek consists of decalcification and later silicification and dolomitization. These processes are illus- trated on addition/depletion diagrams (figs. 2 and 3). Gold mineralization is associated with significant enrichment of $\mathrm{As}, \mathrm{Sb}$, and $\mathrm{Hg}$ and minor enrichment of $\mathrm{Ba}, \mathrm{Cu}, \mathrm{Zn}$, and V (fig. 3).

The Pilot Shale has about the same amount and type of organic carbon (1-3 weight percent, marine) as the shales of the Comus, but the shales of the Wondruff have significantly more organic carbon ( 15 weight fercent) that has a continental source (Dean and others, 1987). The shales of the Pilot and Woodruff are as calcarious and as 
Table 1. Average chemical composition of unoxidized, unmineralized black shales of north-central Nevada [In weight percent]

\begin{tabular}{|c|c|c|c|c|c|c|c|c|c|c|c|}
\hline Unit & $\begin{array}{l}\text { Associated } \\
\text { gold deposit }\end{array}$ & $\mathrm{SiO}_{2}$ & $\mathrm{Al}_{2} \mathrm{O}_{3}$ & $\mathrm{CaO}$ & $\mathrm{MgO}$ & $\mathrm{FeO}$ & $\mathrm{Na}_{2} \mathrm{O}$ & $\mathrm{K}_{2} \mathrm{O}$ & $\mathrm{TiO}_{2}$ & $\mathrm{Ti} / \mathrm{Al}$ & $\begin{array}{r}\text { Number of } \\
\text { analyses }\end{array}$ \\
\hline Comus Formation... & . Rabbit Creek. & .52 .26 & 9.11 & 11.35 & 3.71 & 4.82 & 0.30 & 1.83 & 0.79 & 0.087 & 110 \\
\hline Pilot Shale............... & ..Alligator Ridg & .53 .50 & 4.32 & 5.67 & 3.82 & 2.35 & 0.17 & 1.58 & 0.24 & 0.056 & 3 \\
\hline Woodruff Formation & ..None ........... & N/A* & 6.55 & 13.02 & 7.00 & 1.77 & 0.17 & 2.07 & 0.26 & 0.040 & 4 \\
\hline
\end{tabular}

Not analyzed.

Table 2. Average trace element content of unoxidized, unmineralized black shales of north-central Nevada [In parts per million. N/A indicates not analyzed]

\begin{tabular}{|c|c|c|c|c|c|c|c|c|c|c|c|c|c|c|c|}
\hline Formation & $\mathrm{Sr}$ & As & $\mathrm{Sb}$ & $\mathrm{Hg}$ & $\mathrm{Cu}$ & $\mathrm{Pb}$ & $\mathrm{Zn}$ & Mo & $V$ & $\mathrm{Ni}$ & Co & $\mathrm{Ag}$ & Th & $\mathrm{U}$ & $\begin{array}{c}\text { Number of } \\
\text { analyses }\end{array}$ \\
\hline Comus Formation ...........47 & 128 & 231 & 9 & 2,774 & 25 & 7 & 48 & 2 & 14 & 13 & 8 & 0.36 & 3 & 6 & 28 \\
\hline Pilot Shale..................330 & 328 & 330 & 9 & 453 & 30 & 12 & 149 & 5 & 67 & 74 & 13 & 0.27 & 6 & 2 & 3 \\
\hline Woodruff Formation......833 & 290 & 80 & 45 & N/A & 141 & 12 & 1,337 & 84 & 3,148 & 285 & 4 & 2.25 & 5 & $\mathrm{~N} / \mathrm{A}$ & 4 \\
\hline USGS Standard SDO-1 ...397 & 75 & 69 & 4 & 2 & 60 & 28 & 64 & 134 & 160 & 100 & 47 & 0.13 & 10 & 49 & $1-26 *$ \\
\hline Metalliferous Black & & & & & & & & & & & & & & & \\
\hline Shale** .............. 1,000 & 1,500 & 137 & 9 & 4 & 120 & 56 & 128 & 134 & 320 & 199 & 47 & 0.26 & 21 & 49 & \\
\hline
\end{tabular}

*Number of analyses varies depending on the element.

**Huyck (1990, written commun.). 


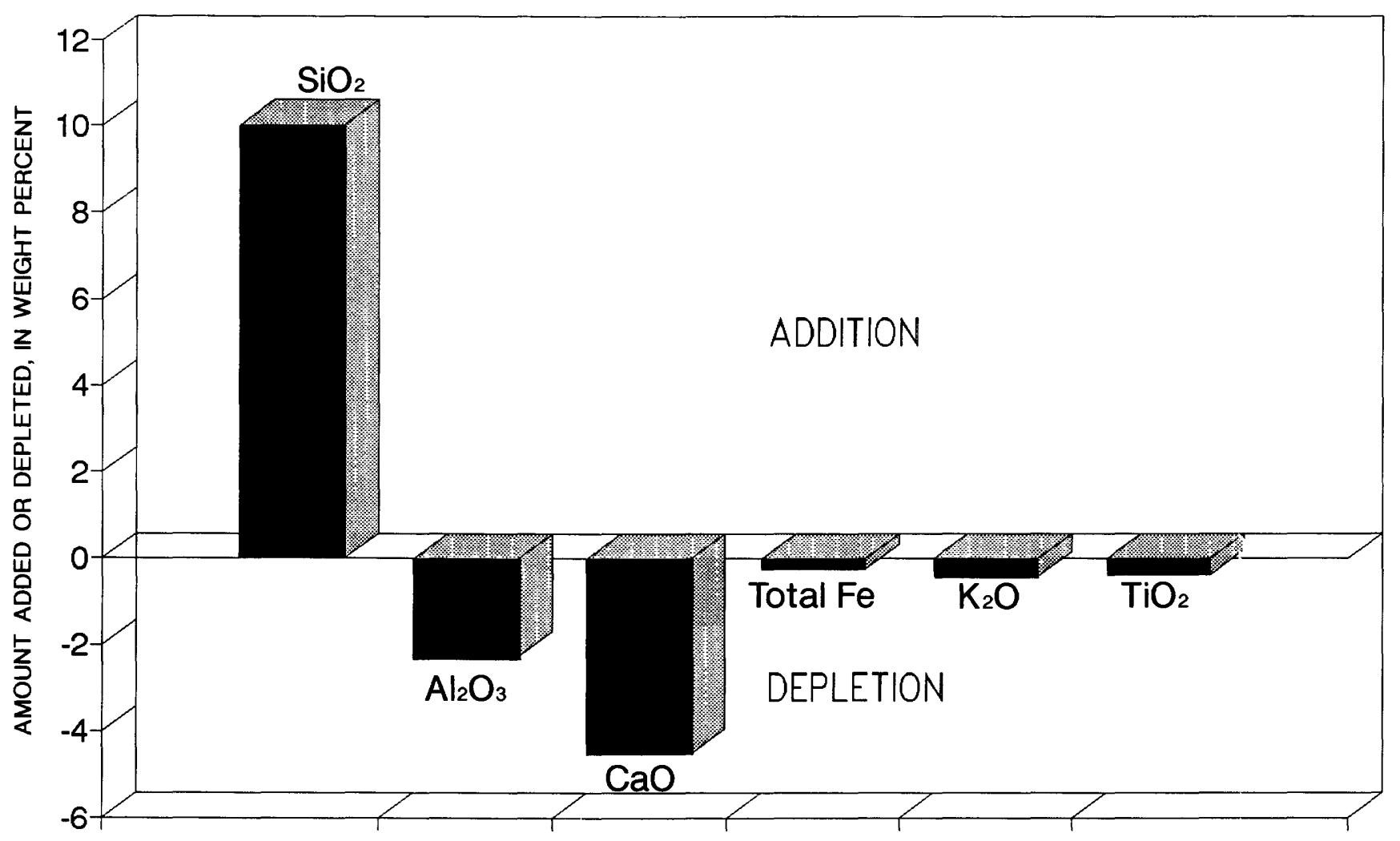

Figure 2. Geochemical addition and depletion associated with gold mineralization in the Comus Formation.

dolomitic as the shale of the Comus (table 1). Relative to the Comus, the source rocks for shales of the Pilot and Woodruff are apparently nonvolcanic and have lower $\mathrm{TiO}_{2} / \mathrm{Al}_{2} \mathrm{O}_{3}$ ratios $(0.056$ and 0.040 , respectively). Similar to the Comus, the Pilot Shale is enriched in $\mathrm{As}, \mathrm{Sb}, \mathrm{Hg}$, $\mathrm{Ag}, \mathrm{Sr}$, and $\mathrm{Zn}$ relative to standard SDO-1. In contrast, the shales of the Woodruff are highly organic-rich black shales that have high contents of such trace elements as $\mathrm{V}, \mathrm{Ni}, \mathrm{Zn}, \mathrm{Cu}, \mathrm{Ag}, \mathrm{Sr}$, and $\mathrm{Ba}$ (table 2). Their composition is similar to that suggested as the standard for defining "metalliferous black shales" (H.L.O. Huyck, 1990, written commun.).

Geochemical features make Paleozoic black shales such as the Comus and Pilot favorable host rocks for Oligocene-Miocene gold mineralization: (1) relatively significant amounts of $\mathrm{CaO}$ (5-13 weight percent) and $\mathrm{MgO}$ (3-7 weight percent) allow decalcification and result in increased permeability; (2) relatively low organic carbon content (1-5 percent) promotes permeability; organic carbon content of more than 10 percent probably inhibits permeability; and (3) strong thermal maturation of organic carbon may provide high sorption capacity for precipitating gold from hydrothermal solution.

\section{REFERENCES CITED}

Bloomstein, E.I., Massingill, G.L., Parratt, R.L., and Peltonen, D.R., 1991, Discovery, geology and mineralization of the Rabbit Creek Gold deposit, Humboldt Courty, Nevada, in Geology and ore deposits of the Great Basin: Geological Society of Nevada, Reno, Symposium Proreedings, v. 2, p. 821-844.

Dean, W.E., Pratt, L.M., Briggs, T.A., Daws, T.A., Engleman, E.E., Jackson, L.L., Layman, L.R., Ryder, J.I.., Stone, C.L., Threlkeld, C.N., and Vuletich, A.K., 1987, Data on geochemistry of Carlin-type disseminated gold deposits and associated rocks, north-central Nevada: U.S. Geological Survey Open-File Report 87-4466, 22 p.

Ilchik, R.P., and Brimhall, G.H., 1986, Hydrothermal maturation of indigenous organic matter at the Alligat $>r$ Ridge gold deposits, Nevada: Economic Geology, v. 81, p. 113-130.

Philp, R.P., 1985, Fossil fuel biomarker, application and spectra: Amsterdam, Elsevier, 294 p.

Spears, D.A., and Kanaris-Sotirou, R., 1976, Titanium in some carboniferous sediments from Great Britain: Geochimica et Cosmochemica Acta, v. 40, p. 345-351. 


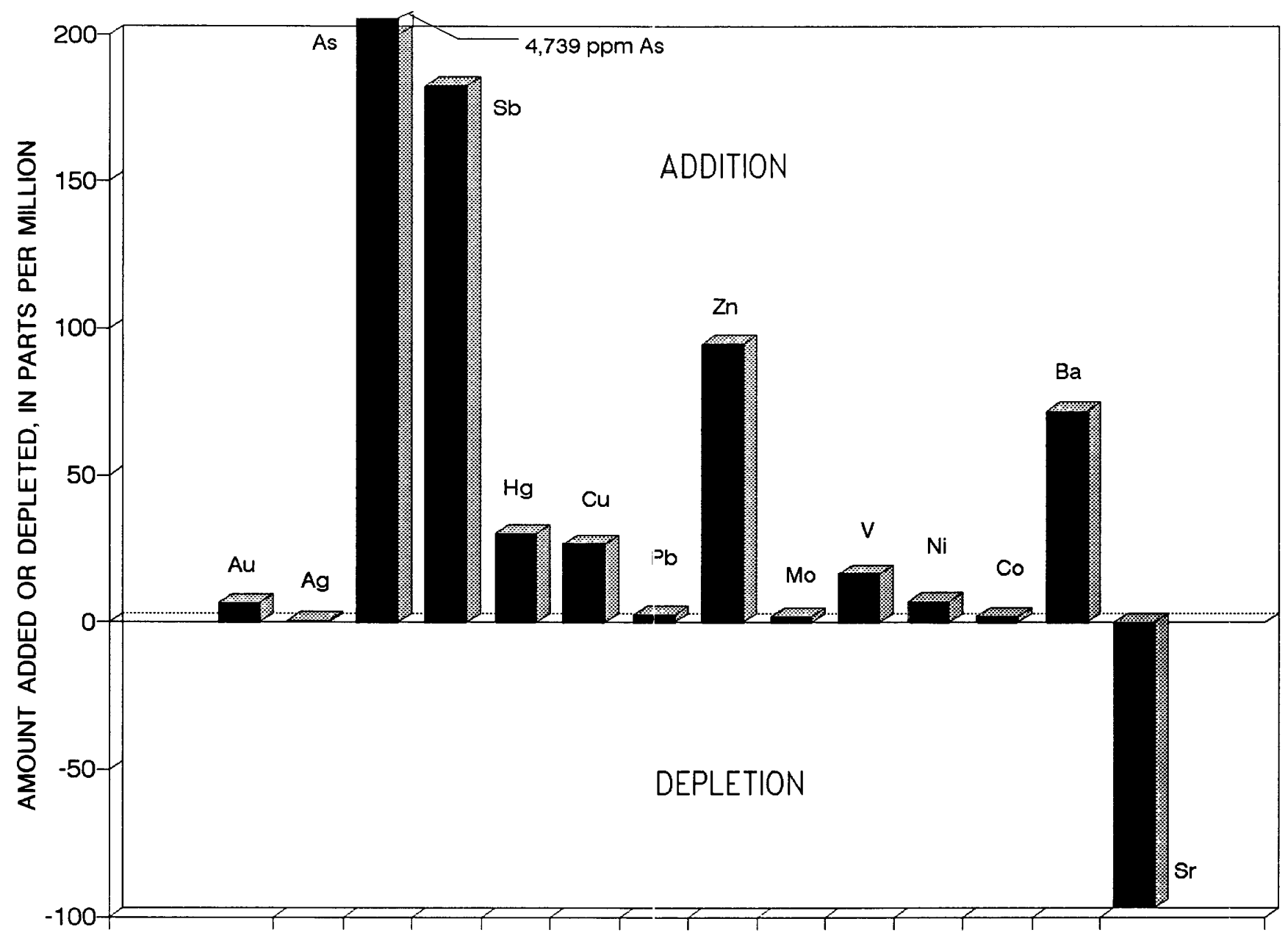

Figure 3. Trace-element addition and depletion associated with gold mineralization in the Comus Formation. 


\title{
Geochemical Control on the Abundance of Vanadium in Black Shales and Other Carbonaceous Rocks
}

\author{
By George N. Breit ${ }^{1}$, Richard B. Wanty ${ }^{1}$, and Michele L. Tuttle ${ }^{1}$
}

High concentrations of vanadium ( $>500 \mathrm{ppm})$ in black shales and other carbonaceous rocks can be explained by processes active at their time of deposition. Attributes common to most of these vanadiferous rocks include (1) strong vanadium-organic carbon correlations, (2) proximity to rocks enriched in phosphate, (3) high contents of organically bound sulfur, and (4) relatively slow rates of deposition in marine basins. Chemical conditions in the sediment and water column likely to produce these attributes were considered together with the general geochemical characteristics of vanadium to identify conditions favoring vanadium accumulation. The geochemistry of vanadium was evaluated by combining existing thermodynamic data for dissolved vanadium species and results of experimental studies of vanadium adsorption and reduction (Wanty, 1986; Breit and Wanty, unpublished data).

Reduction/oxidation, adsorption, and complexation control the mobility and accumulation of vanadium (fig. 1). Vanadate species (V(V)), the dominant species in aerated surface waters, adsorbs strongly to some mineral surfaces, particularly ferric oxides, and limits the concentration of dissolved vanadium in waters of moderate $\mathrm{pH}$. Adsorption to biogenic particles such as fecal pellets contributes to the depletion of dissolved vanadium in shallow-marine waters and the addition of vanadium to sediments (Collier, 1984). In oxic waters, most vanadium will eventually redissolve during remineralization of the settling particles. In shallow oxic or deeper anoxic waters, the association of detrital organic matter and vanadium is more likely to be preserved. The amount of adsorbed vanadium may further increase in anoxic waters because of the reduction of vanadate (V(V)) to vanadyl (V(IV)), which has a greater tendency to adsorb. Natural reductants capable of reducing $\mathrm{V}(\mathrm{V})$ include dissolved organic compounds and $\mathrm{H}_{2} \mathrm{~S}$, or organic constituents on the surface of settling particles. Formation of stable organic

${ }^{1}$ U.S. Geological Survey, Denver Federal Center, Box 25046, MS 916, Denver, Colorado 80225. complexes by the vanadyl ion relative to many transition metals explains why vanadium and organic carbon are well correlated $\left(r^{2}>0.8\right)$ in many carbonaceous units. The reported high abundances of vanadyl-organi: species in petroleum attests to the particular stability of these complexes (Lewan and Maynard, 1982). Diffusion of vanadium across the sediment-water interface may also increase the concentration of vanadium in sediment. This process is driven by the reduction, complexation, and adsorption of vanadium. Calculations using apparent concentration gradients (Brumsack, 1986) to estimate rates of diffusion suggest that this process is signifirant only in very slowly accumulating sediments $(<0.01 \mathrm{~mm} / \mathrm{yr})$.

Vanadium-rich carbonaceous rocks commonly are interbedded with and transitional to rocks enriched in phosphate. The separation of vanadium-rich carbonaceous and phosphatic rocks in two units is the resul' of the contrasting composition of depositional waters. Phosphate accumulations form when organic matter is partly destroyed under suboxic conditions, whereas carbonaceous matter and associated vanadium are mostly retained by sediments that are in contact with anoxic or euxinic waters.

The presence of organically bound sulfur in vanadium-rich petroleum and in some vanadium-rich carbonaceous rocks suggests that $\mathrm{H}_{2} \mathrm{~S}$ was abundant during early diagenesis of vanadium-rich carbonaceo's sediments (Baker and Louda, 1986; Patterson and others, 1986). $\mathrm{H}_{2} \mathrm{~S}$ not consumed in pyrite formation reac ${ }^{+} \mathrm{d}$ with organic matter or diffused upward, possibly resulting in euxinic bottom waters. Under natural conditicns only $\mathrm{H}_{2} \mathrm{~S}$ is known to reduce $\mathrm{V}(\mathrm{IV})$ to $\mathrm{V}(\mathrm{III})$, an oxidation state that favors incorporation of vanadium into clay minerals. The abundance of vanadiferous clays that contain V(III) in several oil shales and black shales indicates that this process is active during diagenesis of carbonaceous sediments. Vanadium partitioned into clays may be retained during metamorphism to produce vanadium-rich mica in graphitic schist. In chemical or biogenic sediments having high organic carbon to clay ratios, vanadium remains complexed with organic matter and may eventually migrate as a component of petroleum. 


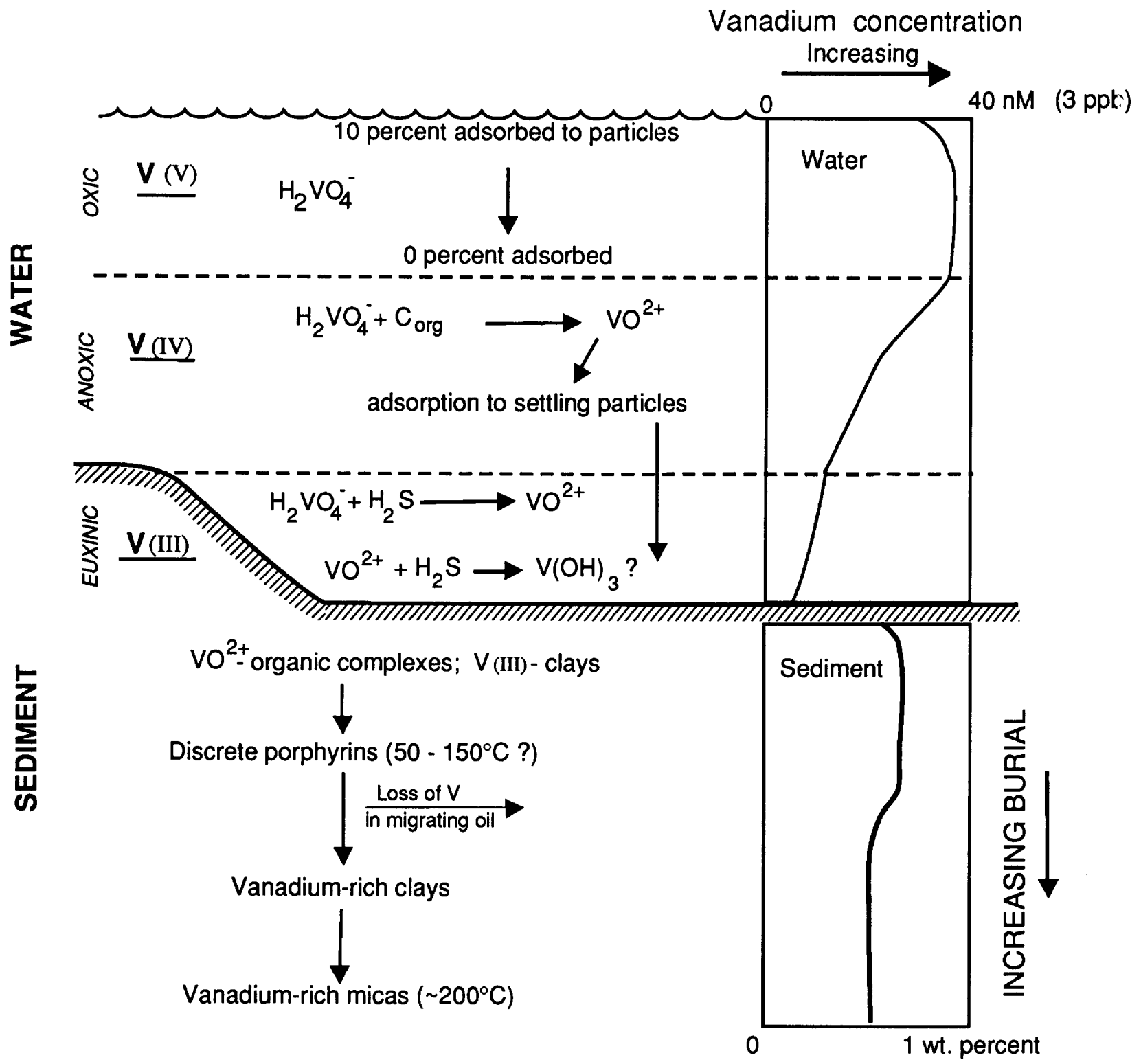

Figure 1. Geochemical processes that affect the abundance and speciation of dissolved vanadium and the distributior of vanadium in sediments during diagenesis. Vanadium concentration profiles are estimated based on the geochemi-al processes. Concentrations in water are nanomolar; concentrations in sediment are weight percent on a dry-weight basis.

The content of vanadium is higher in marine carbonaceous rocks as compared to rocks deposited in lacustrine environments because of the greater amount of vanadium made available by circulating seawater. Massbalance calculations based on modern analogs restrict the abundance of vanadium in lacustrine sediments to less than $200 \mathrm{ppm}$ even if the $\mathrm{Eh}$, abundance of organic carbon, and $\mathrm{H}_{2} \mathrm{~S}$ activity are comparable to those in euxinic marine basins. Similar calculations for a stratified marine basin require that the basin be open to seawater circulation. Open circulation is necessary to supply sufficient vanadium to result in carbonaceous sedimentary rocks having vanadium contents exceeding $500 \mathrm{ppm}$.

\section{REFERENCES CITED}

Baker, E.W., and Louda, J.W., 1986, Porphyrins in the geo'ngical record, in Johns, R.B., ed., Biological markers in the sedimentary record-Methods in geochemistry and geophysics 24: New York, Elsevier, p. 126-225.

Brumsack, H.J., 1986, The inorganic geochemistry of Cret ${ }^{+c e o u s}$ black shales (DSDP Leg 41) in comparison to modern upwelling sediments from the Gulf of Califorria, in Summerhayes, C.P., and Shackleton, N.J., eds., North Atlantic paleoceanography: Geological Society of L.ondon Special Publication 21, p. 447-462.

Collier, R.W., 1984, Particulate and dissolved vanadium in the North Pacific Ocean: Nature, v. 309, p. 441-444. 
Lewan, M.D., and Maynard, J.B., 1982, Factors controlling enrichment of vanadium and nickel in the bitumen of organic sedimentary rocks: Geochimica et Cosmochimica Acta, v. 46, p. 2547-2560.

Patterson, J.H., Ramsden, A.R., Dale, L.S., and Fardy, J.J., 1986, Geochemistry and mineralogical residences of trace elements in oil shales from Julia Creek. Queensland, Australia: Chemical Geology, v. 55, p. 1-16.

Wanty, R.B., 1986, Geochemistry of vanadium in an epigenetic sandstone-hosted vanadium-uranium deposit. Henry basin, Utah: Golden, Colorado School of Mines, Ph.D. thesis, $198 \mathrm{p}$. 


\title{
Nickel-Molybdenum-Platinum-Gold Deposits in Black Shales of Southern China- A New Ore Type with Possible Analogs in
Pennsylvanian Rocks of the U.S.A.
}

\author{
By Raymond M. Coveney, Jr., ${ }^{1}$ and Chen Nansheng ${ }^{2}$
}

Since 1985, deposits near Songlin, Zunyi County, Guizhou Province, in the People's Republic of China have been mined for molybdenum. Thin nodular sulfide lenses in a 2-m-thick horizon of black shale just above the Proterozoic-Cambrian boundary contain 2-7 percent Mo and as much as 4 percent $\mathrm{Ni}, 2$ percent $\mathrm{Zn}, 0.7 \mathrm{ppm}$ $\mathrm{Au}, 50 \mathrm{ppm} \mathrm{Ag}, 0.3 \mathrm{ppm} \mathrm{Pt}$, and $30 \mathrm{ppb}$ Ir (Chen and others, 1982; Fan, 1983; Fan and others, 1984; Chen, 1988; Chen and Coveney, 1988; Coveney and Chen, 1989). Our analyses indicate the presence of 1-2.5 percent As and as much as 2,700 ppm Se. The Zunyi Mo mines currently produce about 1,000 tons of molybdenum ore per year and are the only mines in the world where molybdenum is recovered from shale. Precious metals are not recovered from the ores, but mill tailings are being stockpiled for their future recovery.

Metal-rich Cambrian black shales are in nine other provinces in southern China (Chen and others, 1982). For example, about $350 \mathrm{~km}$ east of Zunyi (fig. 1), Cambrian shales near Dayong, Hunan, contain similar nodular nickelmolybdenum sulfide lenses enriched in platinum-group elements (Fan, 1983). Other nickel-molybdenum deposits are in Cambrian shales near Dezhe, Yunnan (Chen and others, 1982), and in metamorphosed Lower Cambrian beds near Lizhe, Zhejiang (Chen and Yang, 1987). None of these deposits has any obvious connection with ultramafic source rocks, although ophiolites are present in the general region (fig. 1).

Nodular textures (Fan, 1983), the presence of siliceous venting tubes, and other features imply that hydrothermal submarine springs related to basement faults de-

\footnotetext{
${ }^{1}$ Department of Geosciences, University of Missouri-Kansas City, Kansas City, Missouri 64110.

${ }^{2}$ Institute of Geochemistry, Academia Sinica, Guiyang. Guizhou Province, People's Republic of China.
}

posited metals during sedimentation (Chen, 1988); however, in some cases a nonsyngenetic component to the mineralization may be significant. Results of five measurements of sulfur isotope deviations $\left(\delta^{34} S\right)$ for samples drilled from pyrite nodules from Zunyi and Dayong are from -11.2 to -7.3 per mil relative to the Cañon Diablo troilite standard and average -9.94 per mil. Rims of porous (and possibly corroded) pyrite are on some sulfide nodules. Analysis of the rim of one such nodule from Zunyi yielded a $\delta^{34} \mathrm{~S}$ value of +3.7 per mil in contrast with -10.2 per mil for the interior. Energy-disnersive scanning electron microscopy of this pyrite nodule and others indicates that late pyrite rims contain more $\mathrm{Ni}, \mathrm{Mo}$, As, and Se than the interiors. Lyons (1989) has discussed somewhat analogous isotopic variations in a bed of iron sulfide from the Devonian of New York. One of the possible interpretations that he infers for subtly enriched values for $\delta^{34} S$ on the fringes of nodules is progressive enrichment of heavy sulfur resulting from a closed system. This process may also be operative in the case of the Chinese deposits, but the striking compositional changes between the interior and rim of at least one sulfide nodule suggest the possibility of two stages of mineralization. The first stage is likely hydrothermal and syngenetic. The second stage may be a supergene event related to the modern regional karstification that is spectacularly well developed in southern China. The second stage of mineralization may also be related to ancient weathering. For example, the deposits may be analogous to uncorformity uranium deposits, which are related to deep ancient weathering events and which also can have enriched platinum-group-element values (Grauch, 1989).

The Chinese deposits were first discovered during the 1970's, and similar deposits may have been overlooked elsewhere in the world. High platinum values are known from shales in Poland (Kucha, 1982), and sulfide 


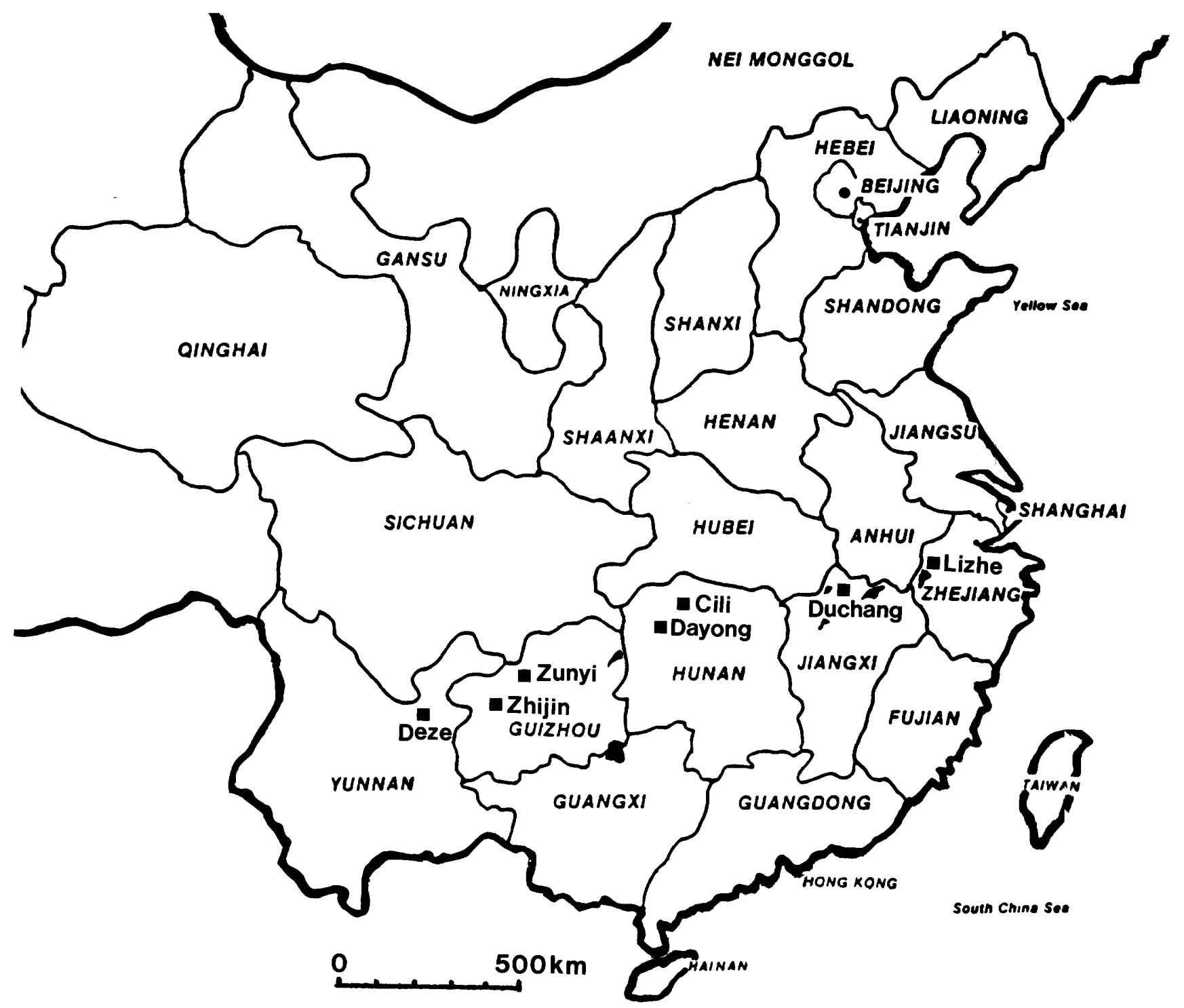

Figure 1. Nickel-molybdenum-platinum-gold deposits (solid squares) hosted by Cambrian black shales in southern China. Nickel-molybdenum sulfide lenses or layers are found at Dezhe, Zhijin, Zunyi, Cili, Dayong, Duchang, and Lizhe.. Ophiolites (shown as irregular black areas) are exaggerated in size for clarity; locations are from Hsu and others (1988).

deposits resembling the Chinese deposits have recently been discovered in Canada (L. Hulbert, Canadian Geological Survey, oral commun., 1988). In addition, extensive molybdenum-rich shales in the Pennsylvanian of the central U.S. (Coveney and Martin, 1983) may have ore-grade enrichments associated with basement structures such as the Humboldt fault of Kansas and the Reelfoot rift zone of Illinois. Orth and others (1988) found whole-rock values for platinum as high as $160 \mathrm{ppb}$ in Carboniferous beds of Oklahoma not far from the extension of the Humboldt fault. Distal to this major basement structure in Linn County, Kansas, and Platte County, Missouri, what may be minor expulsion vents have been observed in limestones associated with metal-rich Pennsylvanian shales in the form of mineralized animal burrows or root casts containing ferroan dolomite, with or without petroleum, hydrothermal quartz, calcite, barite, $o^{*}$ sphalerite (Coveney, 1991).

The recently discovered nickel-molybcenum-platinum-gold deposits of China and related deposits associated with black shales may constitute a resource of global significance for nickel, molybdenum, and platinum-group metals. The presence of a major molybdenum anomaly in Pennsylvanian beds comparable to that in Chinese Cambrian shales and the high platinum-group-element values in the Carboniferous rocks of Oklahoma suggest that regional exploration for similar deposits may $b$ ? warranted in the U.S.A. 


\section{REFERENCES CITED}

Chen Nansheng, 1988, The Cambrian hydrothermal sedimentary molybdenum and nickel ore deposits in south China: International Association of Sedimentologists, International Symposium on Sedimentology Related to Mineral Deposits, Beijing, Abstracts, p. 29.

Chen Nansheng, and Coveney, R.M., 1988, Ores in metal-rich shales of China [abs.]: U.S. Geological Survey Circular 1037 , p. 7-8.

Chen Nansheng, and Yang Xiuzhen, 1987, Studies of Lizhe molybdenum ore deposit of sedimentary-magmatic hydropneumatic origin, Lizhe, Zhejiang province (in Chinese): Geochimica, v. 9, p. 208-214.

Chen Nansheng, Yang Xiuzhen, Liu Dehan, Xiao Xuejun, Fan Delian, and Wang, Lianfang, 1982, Lower Cambrian black argillaceous and arenaceous rock series in south China and its associated stratiform deposits (in Chinese): Mineral Deposits, v. 1, p. 39-51.

Coveney, R.M., Jr., 1991, Evidence for expulsion of hydrothermal fluids and hydrocarbons in the Midcontinent during the Pennsylvanian, in Proceedings of a Workshop on Source Rocks, Generation, and Migration of Hydrocarbons and Other Fluids in the Southern Midcontinent: Oklahoma Geological Survey Circular 93.

Coveney, R.M., Jr., and Chen Nansheng, 1989, Nickel and molybdenum-rich shales of southern China-A new ore type with possible analogues in the Pennsylvania of the USA: International Geological Congress, 28th, Washington, D.C., Abstracts v. 1, p. I335-I336.
Coveney, R.M., Jr., and Martin, S.P., 1983, Molybdenum and other heavy metals of the Mecca Quarry and Logan Quarry shales: Economic Geology v. 78, p. 132-149.

Fan Delian, 1983, Polyelements in the Lower Cambriar black shale series in southern China, in Augustithis, S.S., ef., The significance of trace metals in solving petrorenetic problems and controversies: Athens, Theophrastus Publications S.A., p. 447-474.

Fan Delian, Yang Ruiying, and Huang Zhongxiang, 1984, The Lower Cambrian black shale series and iridium anomaly in south China, in Developments in geoscience, Contri :utions to the 27th Geological Congress, 1984: Beijing, Moscow Academia Sinica, Beijing, p. 215-224.

Grauch, R.I., 1989, Early-Middle Proterozoic unconformitiesSources for platinum group and precious metals: U.S. Geological Survey Circular 1035, p. 26.

Hsu, K.J., Sun Shu, Chen Haihong, Pen Haipo, and Sengor, A.M.C., 1988, Mesozoic overthrusts in south China: Geology, v. 16, p. 418-421.

Kucha, H., 1982, Platinum group metals in the Zechstein copper deposits, Poland: Economic Geology, v. 77, p. 1578-1591.

Lyons, T.W., 1989, A sulfur isotope study of the Leicester Pyrite Member (Middle Devonian) of western New York State-Preliminary results: U.S. Geological Survey Circular 1037, p. 2-4.

Orth, C.J., Quintana, L.R., Gilmore, J.S., Barrick, J.E., ITaywa, J.N., and Spesshardt, S.A., 1988, Pt-group anomalie? in the lower Mississippian of southern Oklahoma: Geology, v. 16, p. $627-630$. 


\title{
Geochemical and Mineralogical Comparison of the Upper Pennsylvanian Stark Shale Member of the Dennis Limestone, East-Central Kansas, with the Middle Pennsylvanian Mecca Quarry Shale Member of the Carbondale Formation in Illinois and of the Linton Formation in Indiana
}

\author{
By G.A. Desborough', J.R. Hatch ${ }^{2}$, and J.S. Leventhal ${ }^{3}$
}

\begin{abstract}
A geochemical and mineralogical study of the Middle Pennsylvanian Mecca Quarry Shale Member of the Linton Formation in Indiana and of the Carbondale Formation in Illinois and the Upper Pennsylvanian Stark Shale Member of the Dennis Limestone in east-central Kansas was done to compare and contrast the compositions of these two black shales. Generally, the shales have similar organic and inorganic geochemistry and mineralogy.

The mineralogy of the shales is important to understanding the residence of elements and the environment of deposition. Pyrite is the major residence of iron and sulfur, but significant amounts of iron-rich chlorite are present in all samples. Siderite is present in some samples of the Mecca Quarry Shale Member in Indiana. Quartz, kaolinite, and potassium feldspar are the dominant detrital minerals, whereas ubiquitous illite, albite, iron chlorite, pyrite, apatite, and carbonate minerals are of early or late diagenetic origin. During early diagenesis, organic matter was metabolized by sulfate reducers to produce sulfide that reacted with iron, zinc, and other easily leachable or reducible metals $(\mathrm{Cr}, \mathrm{Ni}, \mathrm{Mo}, \mathrm{Se}$, $U$, and V). Some metals were also released from their organic residence site at this time. Gypsum may be of detrital origin.

In both shales, molybdenum, selenium, nickel, vanadium, and chromium are chiefly associated with organic matter. We do not find the vanadium-illite association reported by Coveney and others (1987). The Stark Shale Member
\end{abstract}

'U.S. Geological Survey, P.O. Box 25046, Denver Federal Center, MS 905, Denver, Colorado 80225.

${ }^{2}$ U.S. Geological Survey, P.O. Box 25046, Denver Federal Center, MS 972, Denver, Colorado 80225.

${ }^{3}$ U.S. Geological Survey, P.O. Box 25046, Denver Federal Center, MS 973, Denver, Colorado 80225. generally contains less organic carbon than the Mecca Quarry Shale Member, but the proportion of marine organic matter is higher in many units of the Stark Shale Memker. The Stark Shale Member has an equal or higher ratio of metals (Mo, $\mathrm{V}$, $\mathrm{Zn}, \mathrm{Cd}, \mathrm{Se}, \mathrm{U}, \mathrm{Ni}$, and $\mathrm{Cr}$ ) relative to organic carbon than the Mecca Quarry Shale Member. This may be due to higher availability in terms of source or to chemical complex stability of these metals in a more offshore environment.

\section{INTRODUCTION}

Numerous studies of metal contents and organic matter compositions in Middle and Upper $\mathbf{P}$ nnsylvanian black shales have been published during the last decade (Coveney and others, 1987; Coveney and Glascock, 1989, and references listed therein). The present study was undertaken to compare the bulk mineralogy and inorganic and organic geochemistry for 21 samples from a 53cm-thick section of the Upper Pennsylvanian (Missourian) Stark Shale Member of the Dennis Limestone in Wabaunsee County of eastern Kansas (Stanton and others, 1983) with that for 14 samples of the Middle Pennsylvanian (Desmoinesian) Mecca Quarry Shale Member of the Linton Formation and equivalent beds, $33-55 \mathrm{~cm}$ thick, from Pike and Parks Counties, Indiana, and of the Carbondale Formation in Knox County Illinois (Coveney and others, 1987). (The stratigraphic positions of the Stark Shale Member and the Mecca Quarry Shale Member of Indiana and Illinois and equivalents in Missouri and Kansas are shown in table 1.) Organic carbon, elemental, and mineralogical abundances were determined in crder to study 
Table 1. Stratigraphic position of the Stark Shale Member and the Mecca Quarry Shale Member in relation to other Middle and Upper Pennsylvanian black shales in the Midcontinent, U.S.A.

[Modified from Heckel (1977) for eastern Kansas]

\begin{tabular}{l}
\hline UPPER PENNSYLVANIAN \\
\hline Virgilian Series \\
\hline Larsh Shale Member of the Deer Creek Limestone \\
Queen Hill Shale Member of the Lecompton Limestone \\
Hecbner Shale Member of the Oread Limestone \\
\hline Missourian Series
\end{tabular}

Eudora Shale Member of the Stanton Limestone

Quindaro Shale Member of the Wyandotte Limestone

Muncie Crcek Shale Member of the Iola Limestone

Stark Shale Member of the Dennis Limestone

Hushpuckney Shale Member of the Swope Limestone MIDDLE PENNSYLVANIAN (PART)

Desmoinesian Series

Anna Shale Member of the Pawnee Limestone

Little Osage Shale Member of the Fort Scott Limestone

Excello Shale Member of the Fort Scott Limestone

Mecca Quarry Shale Member of the Carbondale Formation in

Illinois and equivalents in Indiana, Missouri, and Kansas

major and minor element associations. Of primary interest in this study are elements apparently associated with organic matter including $\mathrm{V}, \mathrm{Mo}, \mathrm{Se}, \mathrm{Zn}, \mathrm{Cd}, \mathrm{Ni}, \mathrm{U}$, and $\mathrm{Cr}$.

\section{ENVIRONMENT OF DEPOSITION}

Previous studies of the Mecca Quarry Shale Member in Illinois and Indiana indicate that it was deposited in a relatively near-shore marine environment, whereas Mecca Quarry equivalents in Missouri and Kansas were deposited farther offshore (Coveney and others, 1987). This conclusion is based on the ratio of terrestrial to marine organic matter. The relatively near-shore marine environment received a significantly greater contribution of detrital terrestrial organic matter derived from the ancestral Appalachian peat swamps located near the then equatorial latitudes (Heckel, 1977; Coveney and others, 1987), whereas shales that were farther offshore in Kansas received a larger proportion of marine organic material.

The large interior seas in which these shales were deposited were bounded by low-relief highlands of the late Paleozoic shield on the north side, the Appalachian highlands on the east, the Ouachita-Marathon highlands on the south, and the ancestral Rocky Mountain uplift on the west. It is speculated that these interior seas had access to open-ocean water through an area in western Texas (Heckel, 1977).

The organic-rich Middle and Upper Pennsylvanian shales are inferred to represent maximum incursion of marine transgression (Heckel, 1977) during multiple sea level changes in North America that are now thought to represent the concomitant influences of tectonic activity and glacial and interglacial events in the Southern Hemirnhere (Kline and Willard, 1989).

\section{SAMPLES AND METHODS OF STUDY}

The core samples of the Stark Shale Member have been described by Stanton and others (1983); megarcopically, they are black to gray and massive to laminated. Some contain visible pyrite nodules or lenses, and some are phosphatic. Polished thin sections of 14 samples were studied in reflected and transmitted light. All of the samples are very fine grained and consist of intimate mixtures of minerals and organic matter.

Organic and inorganic geochemical data and X-ray diffraction data were determined for splits of each sample. Analytical data for carbon and sulfur are given in S anton and others (1983). Selenium was determined by X-ray fluorescence using a cadmium radioisotope source and an energy-dispersive analyzer. Other elements were determined by inductively coupled plasma mass spectrometry using the methods of Lichte and others (1987). Nickelfiltered $\mathrm{Cu} \mathrm{K} \mathrm{\alpha}_{\alpha}$ radiation was used with a diffractometer scan rate of $2^{\circ}$ per minute. The same operating conditiors and $\mathrm{X}$-ray tube were used for all analyses. Powdered samples were backpacked into 2-mm-thick mounts. X-ray peak intensities reported are corrected for background. For each mineral, the X-ray diffraction maxima used and their approximate positions are given in table 2, along with detection limits estimated by Carroll (1970). X-ray diffraction analysis was done on splits from samples s'udied by Coveney and others (1987, tables 3 and 4), who used several different analytical methods.

\section{MINERALOGICAL RESULTS}

In addition to quartz, major and minor minerals detectable by X-ray diffraction include iron chlorite, illite, kaolinite, feldspar (albite and potassium feldspar), cr.lcite, dolomite, apatite, pyrite, gypsum, and siderite. Data for the Stark samples are given in table 3; data for the I Tecca Quarry and equivalent samples are given in table 4.

Iron chlorite.-Iron-rich chlorite is present in all of the Stark samples and in 12 of 14 of the Mecca Quary and equivalent samples. Carroll (1970, table 12) observet that about 10 percent iron chlorite must be present in order to detect it by diffractometer using copper radiation. It is important to determine the abundance of this mineral because it contributes significantly to the iron cont nt of bulk samples; in fact, except for pyrite and siderite, it is the major iron host in these samples.

Illite.-Illite is present in all samples and generally is the most abundant clay mineral. The relative abundance as 
Table 2. X-ray diffraction peaks used for estimation of relative abundances of minerals other than quartz in Pennsylvanian shales

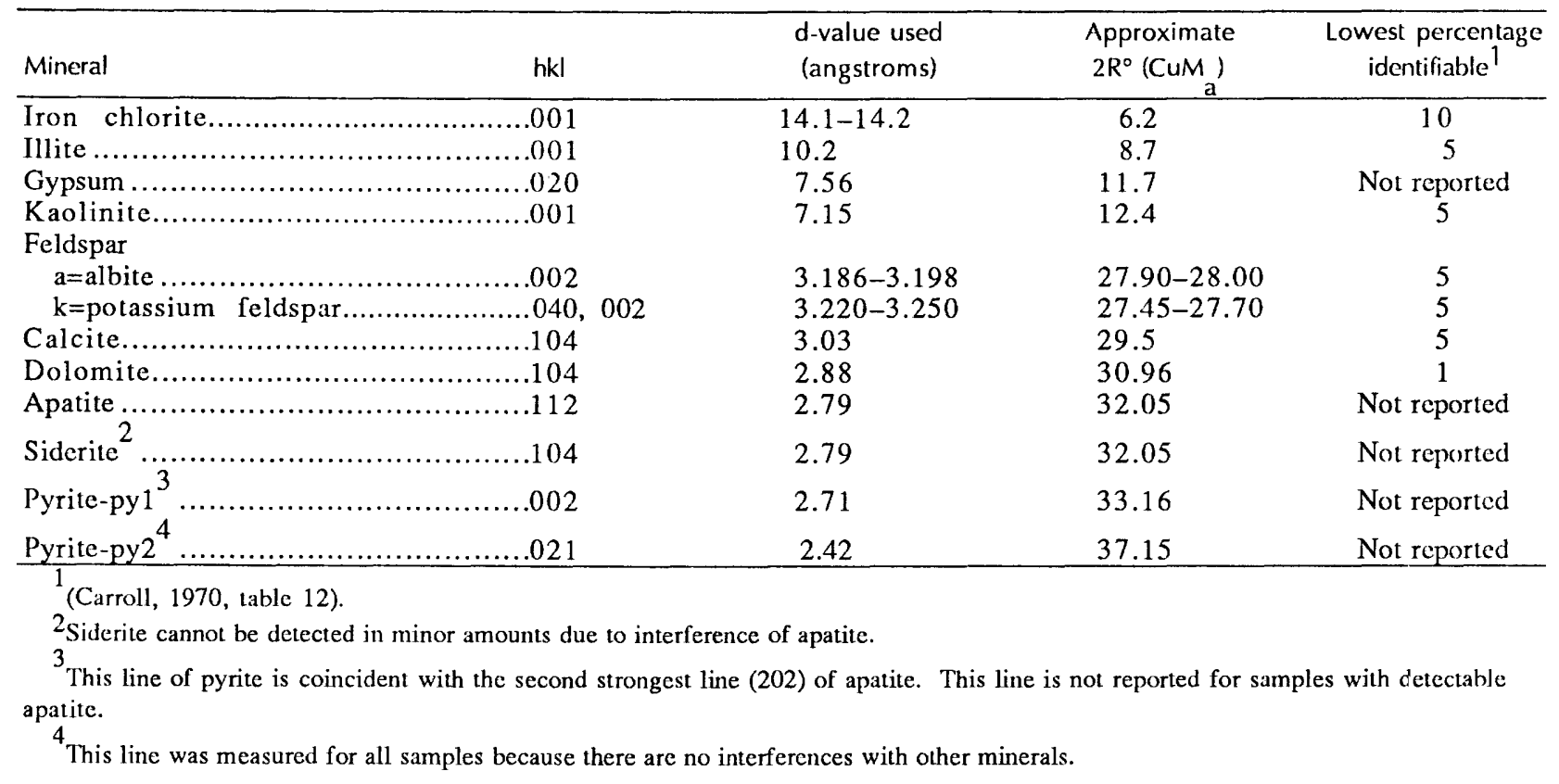

determined from X-ray diffraction intensity data is used here to evaluate the hypothesis of Coveney and others (1987, p. 922) that "most of the V resides in illite."

Kaolinite.-Kaolinite is detectable in all samples; thus it constitutes more than 5 percent (Carroll, 1970) of each bulk sample. The ratio of illite to kaolinite is higher (1.6) for the Stark than the Mecca Quarry and equivalent samples (1.3). The kaolinite probably is chiefly detrital.

Feldspar.-X-ray diffraction data and whole-rock chemical data for sodium indicate that authigenic albite is the dominant feldspar and is present in all samples. A fair correlation ( $r=0.84$ ) exists between the intensity of the albite $002 \mathrm{X}$-ray peak and the sodium content. Potassium feldspar was detected in 15 Stark samples and 3 Mecca Quarry and equivalent samples (tables 3 and 4). The small grain size of quartz and silicate minerals ( $<20$ micrometers) precludes indentification of feldspars in polished thin sections.

Calcite.-Calcite was detected in all Stark samples and in 9 of 14 Mecca Quarry and equivalent samples, but its abundance is quite variable. Calcite is a major mineral in two Stark samples, both of which have very low organic carbon contents ( $<1$ percent).

Dolomite.-Dolomite is present in 19 of 21 Stark samples and in 7 of 14 Mecca Quarry and equivalent samples. Like calcite, its abundance is variable, but unlike calcite, it is not a major mineral in any of the samples.

Apatite.-Apatite is detectable in 14 of 21 Stark samples and in 9 of 14 of the Mecca Quarry and equivalent samples.

Pyrite.-Pyrite is a minor constituent in 19 of 20 Stark samples and in all of the Mecca Quarry and equivalents samples. Because the strongest pvrite peak is coincident with the second strongest apatite peak, the strongest pyrite peak (py1, tables 3 and 4) was measured only when apatite was not detected (see table 2).

Gypsum.-Small amounts of gypsum v'ere detected in seven of the Stark samples and in seven of the Mecca Quarry and equivalent samples. Because the Stark samples are from fresh core, the gypsum is presumed to be an original constituent rather than a product of weathering. The samples of Coveney and others (1987) (Mecca Quarry and equivalents) are from quarries, outcrops, and a coal mine, and the gypsum in them possibly is the result of weathering.

Siderite.-Siderite was not detected in the Stark samples but is present in three of the Mecca Ouarry Shale Member samples from Indiana and Illinoir (table 4). For samples that contain apatite, however, an interference between the strongest siderite $\mathrm{X}$-ray line and that of apatite may prohibit detection of minor amounts of siderite (table 2).

\section{MICROSCOPY}

Polished thin sections of samples of the Stark Shale Member reveal lamination on a fine scale, sparse lenses of pyrite or carbonate, small phosphate nodules and sparse conodonts. Brachiopod valves are in some of tre carbonaterich layers. The mineral grains are generally smaller than 10-20 micrometers and are intimately mixed with organic material. Sulfide minerals are pyrite, sphalerite, and sparse chalcopyrite. Pyrite is present chiefly as frcmboids and 
Table 3. Organic carbon content and X-ray diffraction intensity data for minerals, except quartz, in drill-core samples of the Upper Pennsylvanian Stark Shale Member of the Dennis Limestone, Wabaunsee County, Kansas

[Depth 1,862.8-1,864.5 ft; SW1/4NE1/4SW1/4 sec. 33, T. 13 S., R. $10 \mathrm{E}$. C\%, weight percent organic carbon; ill, illite; kao, kaolinite; fel, feldspar (a is albite, $k$ is potassium feldspar); cal, calcite; dol, dolomite; ap, apatite; py, pyrite; gy, gypsum; sid, siderite; chl, chlorite. $M$ indicates major mineral phase with peak greater than intensity 100. Leaders (-) indicate apatite interference. Numbers in parentheses are estimated detection limits (in percent)]

\begin{tabular}{|c|c|c|c|c|c|c|c|c|c|c|c|c|}
\hline $\begin{array}{l}\text { Sample } \\
\text { number }\end{array}$ & $\begin{array}{l}\mathrm{C} \% \\
(5) \\
\end{array}$ & $\begin{array}{l}\text { ill } \\
(5)\end{array}$ & $\begin{array}{l}\text { kao } \\
(5)\end{array}$ & $\begin{array}{l}\text { fel } \\
(5)\end{array}$ & $\begin{array}{l}\mathrm{cal} \\
(5)\end{array}$ & $\begin{array}{l}\text { dol } \\
(1)\end{array}$ & $\begin{array}{l}\text { ap } \\
\text { (1) }\end{array}$ & $\begin{array}{c}\text { py2 } \\
(5)\end{array}$ & $\begin{array}{l}\text { gy } \\
\text { (5) }\end{array}$ & $\begin{array}{l}\text { sid } \\
(5)\end{array}$ & $\begin{array}{c}\text { chl } \\
(10)\end{array}$ & $\begin{array}{l}\text { py1 } \\
\text { (1) }\end{array}$ \\
\hline$\overline{S-1}$ & 21.7 & 23 & 14 & $16 \mathrm{a}, 6 \mathrm{k}$ & 26 & 17 & 0 & 21 & 0 & 0 & 6 & 28 \\
\hline$S-2-2$ & 24.4 & 30 & 17 & $22 a, 5 k$ & 19 & 18 & 8 & 17 & 0 & 0 & 8 & -- \\
\hline$S-2-1$ & 29.5 & 19 & 12 & $11 \mathrm{a}, 4 \mathrm{k}$ & 20 & 15 & 0 & 12 & 0 & 0 & 4 & 19 \\
\hline$S-3-2$ & 2.0 & 80 & 57 & $10 \mathrm{a}, 12 \mathrm{k}$ & 14 & 13 & 10 & 8 & 6 & 0 & 17 & - \\
\hline S-3-1 & 2.1 & 65 & 48 & $12 \mathrm{a}, 12 \mathrm{k}$ & 15 & 15 & 9 & 9 & 6 & 0 & 11 & -- \\
\hline S-4-3 & 7.5 & 25 & 15 & $25 \mathrm{a}, 6 \mathrm{k}$ & 46 & 12 & 9 & 11 & 0 & 0 & 5 & -. \\
\hline S-4-2 & 10.8 & 26 & 14 & $21 a$ & 41 & 10 & 33 & 9 & 0 & 0 & 8 & -- \\
\hline$S-4-1$ & 21.4 & 31 & 16 & $13 \mathrm{a}, 6 \mathrm{k}$ & 22 & 14 & 12 & 10 & 3 & 0 & 8 & -- \\
\hline$S-5$ & 14.4 & 33 & 14 & $19 a$ & 17 & 14 & 12 & 11 & 4 & 0 & 5 & -- \\
\hline$S-6-2$ & 19.2 & 23 & 10 & $13 a$ & 13 & 8 & 0 & 10 & 0 & 0 & 7 & 15 \\
\hline$S-6-1$ & 11.7 & 17 & 10 & $24 a$ & 23 & 11 & 0 & 27 & 0 & 0 & 4 & 40 \\
\hline S-7 & 2.2 & 28 & 10 & $28 \mathrm{a}, 12 \mathrm{k}$ & 48 & 0 & 5 & 8 & 0 & 0 & 6 & -- \\
\hline S-8-2 & 17.9 & 28 & 15 & $23 a, 8 k$ & 7 & 20 & 36 & 8 & 0 & 0 & 8 & -- \\
\hline S-8-1 & 23.4 & 33 & 18 & $18 \mathrm{a}, 5 \mathrm{k}$ & 11 & 14 & 24 & 5 & 0 & 0 & 6 & -- \\
\hline S-9-2 & 0.5 & 13 & 11 & $14 a$ & $\mathbf{M}$ & 6 & 5 & 0 & 0 & 0 & 3 & 0 \\
\hline S-9-1 & 0.9 & 23 & 8 & $26 \mathrm{a}, 7 \mathrm{k}$ & $\mathbf{M}$ & 0 & 0 & 0 & 4 & 0 & 4 & 5 \\
\hline$S-10$ & 17.8 & 28 & 20 & $17 \mathrm{a}, 4 \mathrm{k}$ & 33 & 17 & 16 & 17 & 0 & 0 & 7 & - \\
\hline$S-11$ & 13.5 & 27 & 12 & $24 a, 7 k$ & 14 & 9 & 0 & 9 & 3 & 0 & 6 & 15 \\
\hline$S-12-2$ & 12.0 & 34 & 21 & $27 a, 6 k$ & 17 & 6 & 5 & 13 & 0 & 0 & 9 & - \\
\hline$S-12-1$ & 23.6 & 25 & 15 & $18 a$ & 26 & 15 & 10 & 17 & 6 & 0 & 5 & -- \\
\hline S-13 & 1.6 & 46 & 18 & $32 a, 8 k$ & 61 & 16 & 7 & 6 & 0 & 0 & 10 & $\ldots$ \\
\hline
\end{tabular}


Table 4. Organic carbon content and $X$-ray diffraction intensity data for minerals, except quartz, in Pennsylvanian black shales in the Midcontinent region [From Coveney and others (1987). C\%, weight percent organic carbon; ill, illite; kao, kaolinite; fel, feldspar (a is albite; $k$ is potassium feldspar); cal, calcite; dol, dolomite; ap, apatite; py, pyrite; gy, gypsum; sid, siderite; chl, chlorite; leaders (--) indicate apatite interference; N.A. indicates not analyzed. Numbers in parentheses are estimated detection limits (in percent)]

\begin{tabular}{|c|c|c|c|c|c|c|c|c|c|c|c|}
\hline Sample & $\begin{array}{l}\text { ill } \\
\text { (5) }\end{array}$ & $\begin{array}{l}\text { kao } \\
\text { (5) }\end{array}$ & $\begin{array}{l}\text { fel } \\
(5) \\
\end{array}$ & $\begin{array}{l}\text { cal } \\
(5)\end{array}$ & $\begin{array}{l}\text { dol } \\
\text { (5) } \\
\end{array}$ & $\begin{array}{l}\text { ap } \\
\text { (1) }\end{array}$ & $\begin{array}{l}\text { py2 } \\
\text { (5) }\end{array}$ & $\begin{array}{l}\text { gy } \\
\text { (5) }\end{array}$ & $\begin{array}{l}\text { sid } \\
(5) \\
\end{array}$ & $\begin{array}{c}\text { chl } \\
(10)\end{array}$ & $\begin{array}{l}\text { Py1 } \\
\text { (1) }\end{array}$ \\
\hline \multicolumn{12}{|c|}{ Mecca Quarry Shale Member, Linton Formation, Hesler Farm, Mecca, Parke County, Indiana } \\
\hline Bed $A(3) \ldots \ldots . . .31 .5$ & 22 & 21 & $13 \mathbf{a}$ & 0 & 5 & $\mathbf{0}$ & 19 & 3 & 5 & 4 & 26 \\
\hline Upper $B(2) \ldots . . .37 .5$ & 20 & 15 & $10 \mathbf{a}$ & $\mathbf{0}$ & $\mathbf{0}$ & 0 & 14 & 5 & 7 & 5 & 23 \\
\hline Bed C .............6.4 & 20 & 20 & $20 \mathrm{a}$ & 9 & 0 & 14 & 9 & 0 & 0 & 6 & -- \\
\hline \multicolumn{12}{|c|}{ Mecca Quarry Shale Member, east of Velpen, Pike County, Indiana } \\
\hline Bed B ............36.8 & 29 & 22 & $14 a, 6 k$ & 2 & 0 & 6 & 19 & 7 & 0 & 3 & - \\
\hline Bed D..........14.7 & 12 & 14 & $9 a$ & 21 & 0 & 0 & 23 & 11 & 0 & 0 & 37 \\
\hline \multicolumn{12}{|c|}{ Mecca Quarry Shale Member, Carbondale Formation, Court Creek, Knoxville, Knox County, Illinois } \\
\hline Bed $A(3) \ldots \ldots \ldots .39 .3$ & 24 & 11 & $7 a, 6 k$ & 3 & 0 & 25 & 5 & 2 & 0 & 3 & $\overline{--}$ \\
\hline Bed $B(2) \ldots \ldots . . .32 .7$ & 22 & 12 & $7 \mathbf{a}$ & 0 & 3 & 13 & 9 & 0 & 0 & 4 & -- \\
\hline Bed C ...............6 & 22 & 12 & $16 a$ & $\mathbf{0}$ & 0 & 0 & 8 & $\mathbf{0}$ & 0 & 6 & 12 \\
\hline Bed D ...........27.9 & 19 & 14 & $9 \mathrm{a}, 7 \mathrm{k}$ & 7 & 7 & 39 & 6 & 0 & 0 & 5 & - \\
\hline \multicolumn{12}{|c|}{ Mecca Quarry Shale Member, Carbondale Formation, Lowell, LaSalle County, central Illinois } \\
\hline Bed B .................A. & 18 & 9 & $9 a$ & 0 & 0 & 0 & 8 & 6 & 15 & 0 & 18 \\
\hline \multicolumn{12}{|c|}{ Shale in Verdegris Limestone Member, Cabaniss Formation, coal mine, Fon Scott, Bourbon County, Kansas } \\
\hline Bed A7...........10.2 & 19 & 15 & $4 a$ & 16 & 26 & 38 & 15 & 0 & 0 & 4 & -- \\
\hline Bed A6............7.6 & 23 & 37 & $14 a$ & 5 & 15 & 17 & 10 & $\mathbf{0}$ & 0 & 3 & - \\
\hline Bed A1(2).......7.6 & 23 & 16 & $17 \mathrm{a}$ & 44 & 17 & 15 & 22 & $\mathbf{0}$ & 0 & 4 & - \\
\hline \multicolumn{12}{|c|}{ Shale in Verdegris Formation, drill-hole BM-2, Randolph County, Missouri } \\
\hline Bed B ............18.5 & 22 & 12 & 6a & 88 & 10 & 28 & 9 & 5 & 0 & 5 & - \\
\hline
\end{tabular}


aggregates of framboids; some pyrite associated with carbonate lenses or phosphate nodules is present as discrete grains or crystals. Pyrite replaces parts of brachiopod valves. Sphalerite generally is present as grains smaller than 10 micrometers in diameter but is larger in some phosphate nodules and incipient replacement of brachiopod values. Local mantling of pyrite framboids by both sphalerite and sparse chalcopyrite indicates that the sphalerite and chalcopyrite formed later than the framboids. In some samples there are two distinct types of organic material; one is red and translucent, whereas the other is opaque.

\section{ASSOCIATION OF ELEMENTS WITH MINERALS OR ORGANIC MATTER}

Tables 5 and 6 give chemical data for 22 major, minor, and trace elements in the Stark samples from Wabaunsee County, Kansas. These chemical data, together with X-ray diffraction data (tables 3 and 4) and studies of polished sections, were used to determine the associations of elements with each other and with the relative abundances of minerals or content of organic carbon for each sample. We used the chemical data of Coveney and others (1987, tables 2 and 3) for the 14 sample splits of the Mecca Quarry and equivalents for which we report X-ray diffraction data on bulk samples (table 3 ).

Iron, sulfur, pyrite, and iron chlorite.-Pyrite commonly is assumed to be the major host of iron and sulfur in these shales (Coveney and others, 1987, fig. 5). Although this generally is the case, other minerals may be present that contain these elements in significant amounts. X-ray diffraction results (table 4) show that three of the samples of Coveney and others (1987) contain both siderite and gypsum, and four others contain minor gypsum. The relations between total sulfur and iron are shown for the Stark samples on figure 1; a "pyrite line" illustrates the relations that would be observed if all of the sulfur and iron were only in pyrite. Except for one sample, all of the data points lie on the "excess iron" side of the pyrite line. Because gypsum is present in two of these samples (table 4), it is inappropriate to assume that all of the sulfur is in pyrite. Figure 2 shows the relations between total sulfur and the intensity of the pyrite peak (py2, table 3) for samples of the Stark; although there is a gross correlation between these two parameters, there is a great deal of scatter. Figure 3 shows the relations between total iron content and the intensity of the pyrite peak (py1, tables 3 and 4) for samples of Stark Shale Member and Mecca Quarry Shale Member that contain no detectable apatite (thus there is no interference between the apatite peak and the strongest peak of pyrite). Based on projection of the zero pyrite peak intensity onto the total iron content line (fig. 3 ), it is clear that about 1.5-1.7 weight percent of the iron present in these samples is not in pyrite; rather, it is in chlorite or siderite, or both, for several of the samples.
Vanadium, organic matter, and illite.-Coven $9 y$ and others (1987, p. 922) and other workers have suggested "most of the V resides in illite" because of the correspondence of the scanning electron microscopy-energy dispersive analytical X-ray results for potassium and vanadium (Coveney and others, 1987, fig. 4). However, carbon and molybdenum data on their figure 4 can be interpreted to show that potassium in the clay and the organic coatings is intermixed with the clay. Our figure 4 shows illit peak intensity versus vanadium content for both samples of the Stark and Mecca Quarry and equivalents; there is no correlation between the abundance of illite and the concentrations of vanadium. Figure 5 shows organic carbon content versus vanadium content for samples of the Stark and Mecca Quarry and equivalents of Coveney and others (1987). The correlation coefficient (r) for 15 of the 19 Mecca Quarry samples is 0.81 , significant at the 0.01 level, and indicates that vandadium is associated statistical $\%$ with organic carbon. For 18 of the 21 Stark Shale Member samples the correlation between vanadium and organic carbon is also high $(r=0.95)$. Some data points for each shale unit are enclosed on figure 5 to emphasize the different ratios of vanadium to organic carbon.

The concentration ratio (ppm V/percent TOC) is higher for samples of the Stark compared to the Mecca Quarry, as shown by (1) the slopes of the trends on figure 5, (2) comparison of the weighted means (percent of interval of each bed multiplied by the concentration of each element, summed for all beds in each interval (see table 7), and (3) the mean values of organic carbon and vanadium (see table 7). For samples of the Mecca Quarry from Pike and Parke Counties, Indiana, weighted means are 26.1 percent

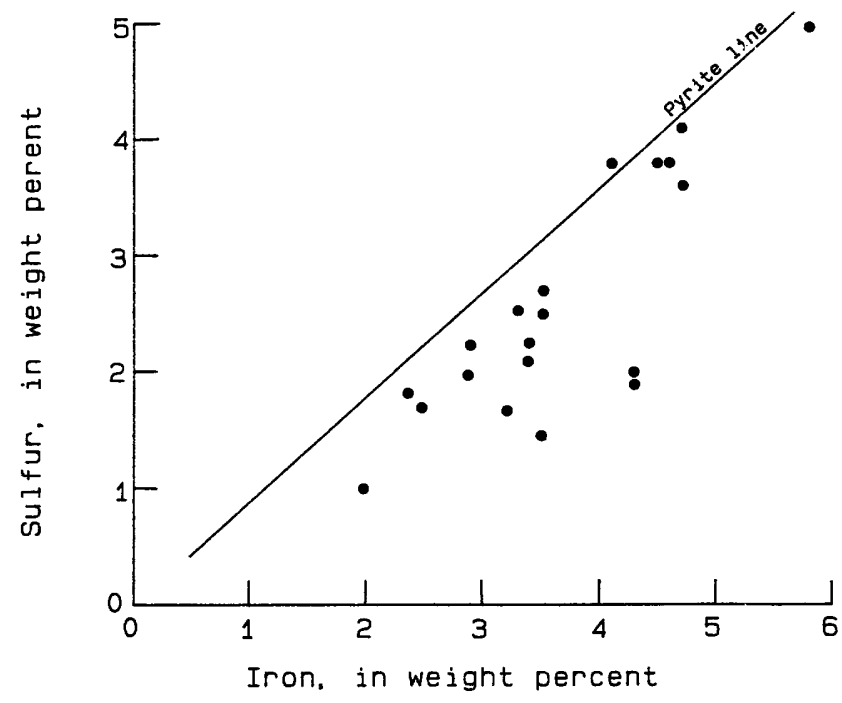

Figure 1. Relations between total sulfur and iron for samples of the Upper Pennsylvanian Stark Shale Member of the Dennis Limestone, Wabaunsee County, Kansas. The line fo- pyrite shows the relations if all the iron and sulfur are only ir pyrite. 
Table 5. Selected major and minor elements in the Stark Shale Member of the Dennis Limestone, Wabaunsee County, Kansas

[In weight percent. Organic carbon and sulfur values are from Stanton and others (1983); other elements determined by inductive coupled plasma method]

\begin{tabular}{|c|c|c|c|c|c|c|c|c|c|c|}
\hline Sample & Organic C & $\mathrm{Al}$ & $\mathrm{Fe}$ & $\mathrm{Mg}$ & $\mathrm{Ca}$ & $\mathrm{Na}$ & $\mathrm{K}$ & $T$ & $P$ & $\mathrm{~S}$ \\
\hline$S-1$ & 21.7 & 5.9 & 4.7 & 1.5 & 2.4 & 0.64 & 0.48 & 0.24 & 0.05 & 4.1 \\
\hline$S-2-2$ & 24.4 & 5.8 & 3.5 & 1.5 & 1.9 & 0.62 & 0.53 & 0.23 & 0.11 & 2.7 \\
\hline $5-2-1$ & 29.5 & 4.8 & 3.8 & 1.5 & 2.8 & 0.47 & 0.41 & 0.20 & 0.12 & 3.3 \\
\hline$S-3-2$ & 2.0 & 11.0 & 4.3 & 1.7 & 0.4 & 0.36 & 1.5 & 0.39 & 0.03 & 2.0 \\
\hline S-3-1 & 2.1 & 11.0 & 4.3 & 1.7 & 0.4 & 0.28 & 1.5 & 0.37 & 0.02 & 2.0 \\
\hline$S-4-3$ & 7.5 & 7.6 & 3.5 & 1.6 & 4.3 & 0.97 & 0.68 & 0.29 & 0.59 & 2.5 \\
\hline$S-4-2$ & 10.8 & 5.6 & 2.9 & 1.2 & 10.0 & 0.82 & 0.47 & 0.23 & 3.2 & 2.2 \\
\hline$S-4-1$ & 21.4 & 6.1 & 3.3 & 1.4 & 2.9 & 0.66 & 0.56 & 0.23 & 0.54 & 2.6 \\
\hline$S-5$ & 14.4 & 8.0 & 3.4 & 1.6 & 2.3 & 0.93 & 0.79 & 0.29 & 0.51 & 2.1 \\
\hline$S-6-2$ & 19.2 & 6.7 & 4.5 & 1.5 & 1.7 & 0.70 & 0.56 & 0.28 & 0.05 & 3.8 \\
\hline$S-6-1$ & 11.7 & 7.1 & 5.8 & 1.6 & 2.6 & 1.20 & 0.68 & 0.27 & 0.08 & 5.0 \\
\hline$S-7$ & 2.2 & 9.7 & 3.2 & 1.6 & 3.1 & 1.60 & 0.91 & 0.37 & 0.11 & 1.6 \\
\hline$S-8-2$ & 17.9 & 5.6 & 2.4 & 1.4 & 7.8 & 0.90 & 0.44 & 0.19 & 2.90 & 1.8 \\
\hline$S-8-1$ & 23.4 & 6.1 & 2.5 & 1.4 & 4.3 & 0.72 & 0.54 & 0.21 & 1.50 & 1.7 \\
\hline$S-9-2$ & 0.5 & 4.2 & 2.9 & 0.8 & 18.0 & 0.75 & 0.28 & 0.16 & 0.18 & 2.0 \\
\hline$S-9-1$ & 0.9 & 7.4 & 2.0 & 1.3 & 9.8 & 1.50 & 0.63 & 0.30 & 0.08 & 1.0 \\
\hline$S-10$ & 17.8 & 6.1 & 4.5 & 1.5 & 4.5 & 0.69 & 0.47 & 0.20 & 0.86 & 3.8 \\
\hline$S-11$ & 13.5 & 7.6 & 3.4 & 1.6 & 2.4 & 1.20 & 0.67 & 0.29 & 0.41 & 2.2 \\
\hline$S-12-2$ & 12.0 & 7.5 & 4.7 & 1.5 & 2.1 & 1.20 & 0.62 & 0.30 & 0.13 & 3.6 \\
\hline$S-12-1$ & 23.6 & 5.5 & 4.1 & 1.4 & 2.9 & 0.66 & 0.41 & 0.20 & 0.31 & 3.8 \\
\hline$S-13$ & 1.6 & 8.6 & 3.5 & 1.8 & 4.5 & 1.10 & 0.72 & 0.36 & 0.19 & 1.4 \\
\hline
\end{tabular}


Table 6. Minor and trace elements in the Stark Shale Member of the Dennis Limestone, Wabaunsee County, Kansas

[In parts per million. Selenium determined by energy-dispersive analysis, other elements by the inductive coupled plasma method. nd indicates not determined]

\begin{tabular}{|c|c|c|c|c|c|c|c|c|c|c|c|c|}
\hline Sample & $\mathrm{Ag}$ & As & $\mathrm{Ba}$ & $\mathrm{Cd}$ & $\mathrm{Cr}$ & Mo & $\mathrm{Ni}$ & Se & $\mathrm{Sr}$ & $U$ & $\mathrm{~V}$ & $\mathrm{Zn}$ \\
\hline$S-1$ & 4 & 40 & 180 & 160 & 660 & 320 & 470 & 140 & 160 & 60 & 2,600 & 3,100 \\
\hline$S-2-2$ & 3 & 30 & 180 & 220 & 760 & 520 & 600 & 195 & 160 & 120 & 3,500 & 3,800 \\
\hline S-2-1 & 9 & 40 & 160 & 230 & 730 & 670 & 600 & nd & 180 & 180 & 3,900 & 5,500 \\
\hline$S-3-2$ & $<2$ & 20 & 490 & 7 & 100 & 29 & 69 & $<10$ & 87 & $<40$ & 210 & 82 \\
\hline S-3-1 & $<2$ & $<10$ & 480 & 6 & 100 & 25 & 69 & $<10$ & 88 & $<40$ & 190 & 62 \\
\hline S-4-3 & 2 & 50 & 240 & 12 & 210 & 67 & 260 & 50 & 330 & $<40$ & 760 & 310 \\
\hline S-4-2 & 4 & 40 & 190 & 52 & 200 & 150 & 290 & 65 & 730 & 150 & 1,200 & 890 \\
\hline S-4-1 & 5 & 30 & 190 & 210 & 390 & 760 & 490 & 125 & 280 & 180 & 3,600 & 2,900 \\
\hline S-5 & 5 & 20 & 230 & 30 & 730 & 93 & 280 & 110 & 260 & 50 & 620 & 1,100 \\
\hline S-6-2 & 7 & 50 & 210 & 150 & 370 & 820 & 540 & 185 & 170 & 70 & 3,200 & 2,500 \\
\hline$S-6-1$ & 7 & 70 & 720 & 75 & 240 & 630 & 370 & 170 & 220 & 120 & 2,000 & 1,800 \\
\hline S-7 & $<2$ & 30 & 860 & 6 & 130 & 15 & 110 & 15 & 360 & $<40$ & 110 & 130 \\
\hline$S-8-2$ & 5 & 10 & 520 & 27 & 870 & 67 & 310 & 85 & 580 & 70 & 370 & 1,400 \\
\hline$S-8-1$ & 5 & 10 & 180 & 22 & 1,100 & 91 & 380 & 110 & 380 & 40 & 490 & 1,100 \\
\hline S-9-2 & $<2$ & 30 & 87 & 2 & 51 & 30 & 49 & $<10$ & 1,200 & $<40$ & 42 & 32 \\
\hline S-9-1 & $<2$ & 20 & 800 & 5 & 83 & 6 & 60 & $<10$ & 680 & $<40$ & 64 & 70 \\
\hline$S-10$ & 8 & 30 & 200 & 110 & 720 & 180 & 350 & 125 & 320 & 120 & 1,600 & 2,200 \\
\hline$S-11$ & 6 & 20 & 720 & 69 & 770 & 170 & 310 & 30 & 260 & 60 & 1,100 & 1,400 \\
\hline$S-12-2$ & 7 & 50 & 670 & 90 & 310 & 440 & 320 & 125 & 210 & 170 & 2,300 & 2,100 \\
\hline S-12-1 & 7 & 40 & 190 & 150 & 540 & 850 & 450 & 145 & 250 & 290 & 3,500 & 3,900 \\
\hline$S-13$ & $<2$ & 20 & 290 & 6 & 150 & 13 & 100 & 25 & 320 & $<40$ & 150 & 110 \\
\hline
\end{tabular}




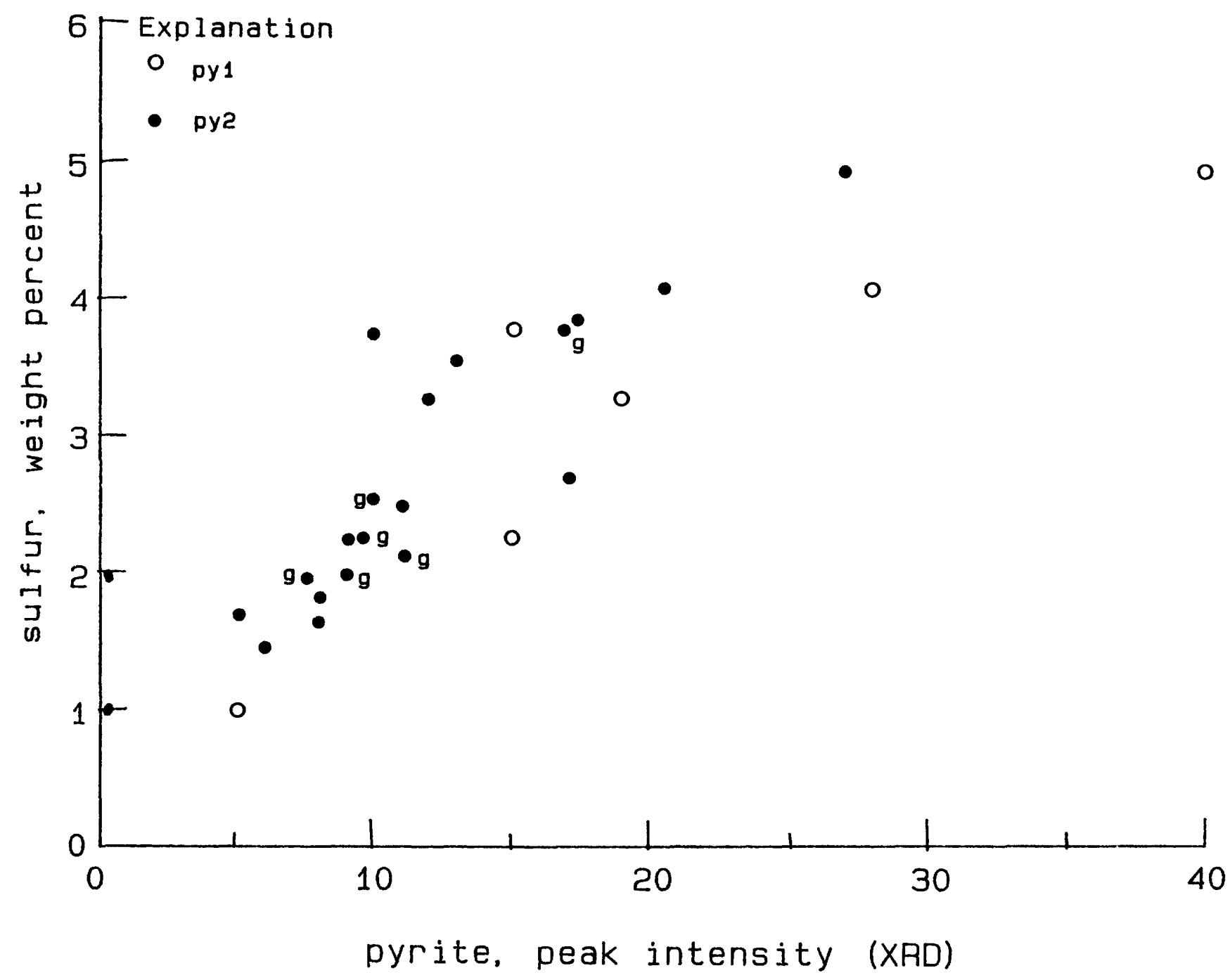

Figure 2. Relations between total sulfur and intensity of pyrite peaks py1 and py 2 for samples of the Stark Shale Member of the Dennis Limestone, Wabaunsee County, Kansas. $g$ indicates that gypsum was detected.

total organic carbon (TOC) and 1,618 ppm V and 25.0 percent TOC and 1,725 ppm V, respectively. For samples of the Stark in Wabaunsee County, Kansas, weighted means are 12.7 percent TOC and $1,831 \mathrm{ppm} \mathrm{V}$. Concentration ratios (ppm V/percent TOC) for the Mecca Quarry samples are 62 and 69 and for the Stark samples 144 (table 7). In other words, organic matter in the Stark samples contains almost twice as much vanadium as does organic matter of the Mecca Quarry samples.

Uranium.-Figure 6 shows no apparent relationship between uranium and phosphorous contents of the Stark samples. The uranium and phosphorous data of Coveney and others (1987, table 2) show similar distributions. Swanson (1960) found that in some black shales of Pennsylvanian age, uranium apparently is associated with phosphorous (apatite). Although the weighted mean values for uranium of the Mecca Quarry are higher than the weighted mean values of the Stark, the ratios of uranium to organic carbon (ppm U/percent TOC) (table 7) are higher for the Stark.

Arsenic.-Contents of arsenic in the Starl: are from less than $10 \mathrm{ppm}$ to $70 \mathrm{ppm}$. The apparent correlation $(r=0.6)$ between the arsenic content and the intersity of the pyrite (py2) peak (fig. 7) indicates that arsenic is present chiefly in pyrite.

Selenium.-Figure 8 shows the relations batween the selenium content and organic carbon content for samples of the Stark. For these samples selenium probably is associated chiefly with organic matter. Although the absolite amount of selenium is higher for samples of Mecca Quarry in Indiana (bed B) than for samples of the Stark (table 7), the ratios of selenium concentration to total organic matter content are not statistically different $(6.8$ versu: $6.3 \mathrm{ppm}$ Se/percent TOC, table 7). 


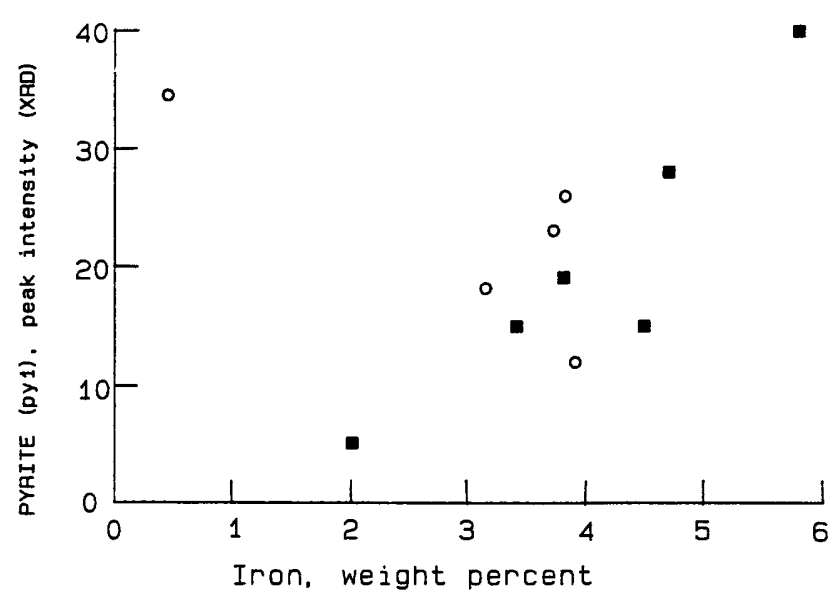

Figure 3. Relations between total iron content and intensity of the strongest pyrite peak (py1) for samples of the Stark Shdie Member (solid square) and Mecca Quarry Shale Member (open circle) that contain no detectable apatite as indicated using X-ray diffraction.

Nickel.-The association between nickel and organic carbon content for the Stark samples is shown on figure 9. Data for five samples of the Mecca Quarry and equivalents from Indiana, Illinois, Missouri, and Kansas (Coveney and others, 1987) are also shown. The weighted mean values for bed B of the Mecca Quarry in Indiana are $450 \mathrm{ppm} \mathrm{Ni}$ and 35.7 percent organic carbon (table 7). The weighted mean values for the Stark samples are $290 \mathrm{ppm} \mathrm{Ni}$ and 12.7 percent organic carbon. The calculated concentration ratio (table 7) for the Stark is almost twice that for the Mecca Quarry.

Zinc.-Zinc is present chiefly in sphalerite that is generally very fine grained ( $<5$ micrometers); however, for 11 of 15 samples of the Stark the correlation between organic matter content and zinc content is good (fig. 10). For some of the Stark Shale samples the relationship between the contents of zinc and phosphorous is inverse. We do not understand this relationship because in the polished thin sections neither apatite nor sphalerite replace each other. Table 7 shows the weighted means and means and concentrations ratios for zinc $(\mathrm{ppm} /$ percent organic carbon) for the Mecca Quarry and the Stark. With the exception of the Mecca Quarry samples from Knox County, Illinois, the ratio of zinc to organic carbon is considerably higher for samples of the Stark Shale Member.

Molybdenum.-The absolute amount of molybdenum in the Mecca Quarry samples is significantly higher than in the Stark Shale Member samples (table 7). Molybdenum probably is mostly associated with organic carbon but does not correlate well with organic carbon content (Coveney and others, 1987, fig. 3). Figure 12 shows pyrolysis gas chromatograms (for experimental method see Leventhal, 1981) for two Stark samples that have similar organic carbon contents. Sample S-8-2 containing $67 \mathrm{ppm}$ Mo is mainly marine-sourced organic matter as indicated by the predominance of $n$-alkanes. In contrast, sample $S-6-1$ containing $630 \mathrm{ppm}$ Mo has a significant propotion of land-sourced organic matter as indicated by the non- $n$ alkane components. Similar pyrolysis gas chroma+ngrams for samples of the Mecca Quarry from different localities show that samples have variable amounts of land- and marine-derived organic matter (Coveney and others. 1987). Although the concentration ratios (mean values) of molybdenum to organic carbon (table 7) for the Mecca Qu?rry and the Stark are not significantly different, the highest molybdenum contents are associated with samples h?ving a substantial terrestrial organic matter component (Coveney and others, 1987).

Chromium.-There is some association between chromium and organic carbon contents, but there is considerable scatter of the data. In the absence of recornizable chromium-bearing minerals, it is assumed that chronium is associated with organic matter. The weighted mean data and the concentration ratios of chromium to organic ca-bon for Mecca Quarry and Stark samples show that, althou $\mathrm{sh}$ there is more chromium in bed B in Indiana than in the S ark, the ratio of chromium to organic carbon in the Stark is about twice that of the Mecca Quarry in Indiana.

Association of zinc and nickel.-Figure 13 illustrates the association of zinc and nickel in organic-rich marine strata of Devonian and Mississippian age and in the Stark and Mecca Quarry samples. Even though zinc is present chiefly in sphalerite and nickel is correlated with organic carbon, the relationship between the concentrations of these two elements is generally linear (fig. 12), except wr ere zinc has been mobilized (enriched with respect to nickel) or is, at least in part, of epigenetic origin. For example, the Mecca Quarry sample having the highest concentration (nct. shown on fig. 13) of zinc (5,300 ppm, Coveney and others, 1987, table 3 ) is one that has some epigenetic zinc, as evidenced by anomalously high concentrations of sulfur, iron, and barium compared to the other samples. Geochemical profiles for zinc and nickel in the Devonian and Mississippian New Albany Shale in Indiana (Beier and Hayes. 1989, fig. 3) likewise show that nickel and zinc have proprrtional, or somewhat constant, concentration relations, exce tt where sphalerite-rich phosphate nodules are present (Beier and Hayes, 1989, fig. 2). The reason for the relatively linear relation of zinc and nickel in these organic-rich $D$ vonian, Mississippian, and Pennsylvanian strata is not know'n, but it is probably related to the availability and the soluhility of both of these metals.

\section{SUMMARY}

Integrated mineralogical and chemical stıdies of metalliferous marine black shales of Pennsylvanian age provide clues to the relationships of element residence in minerals and organic matter. 


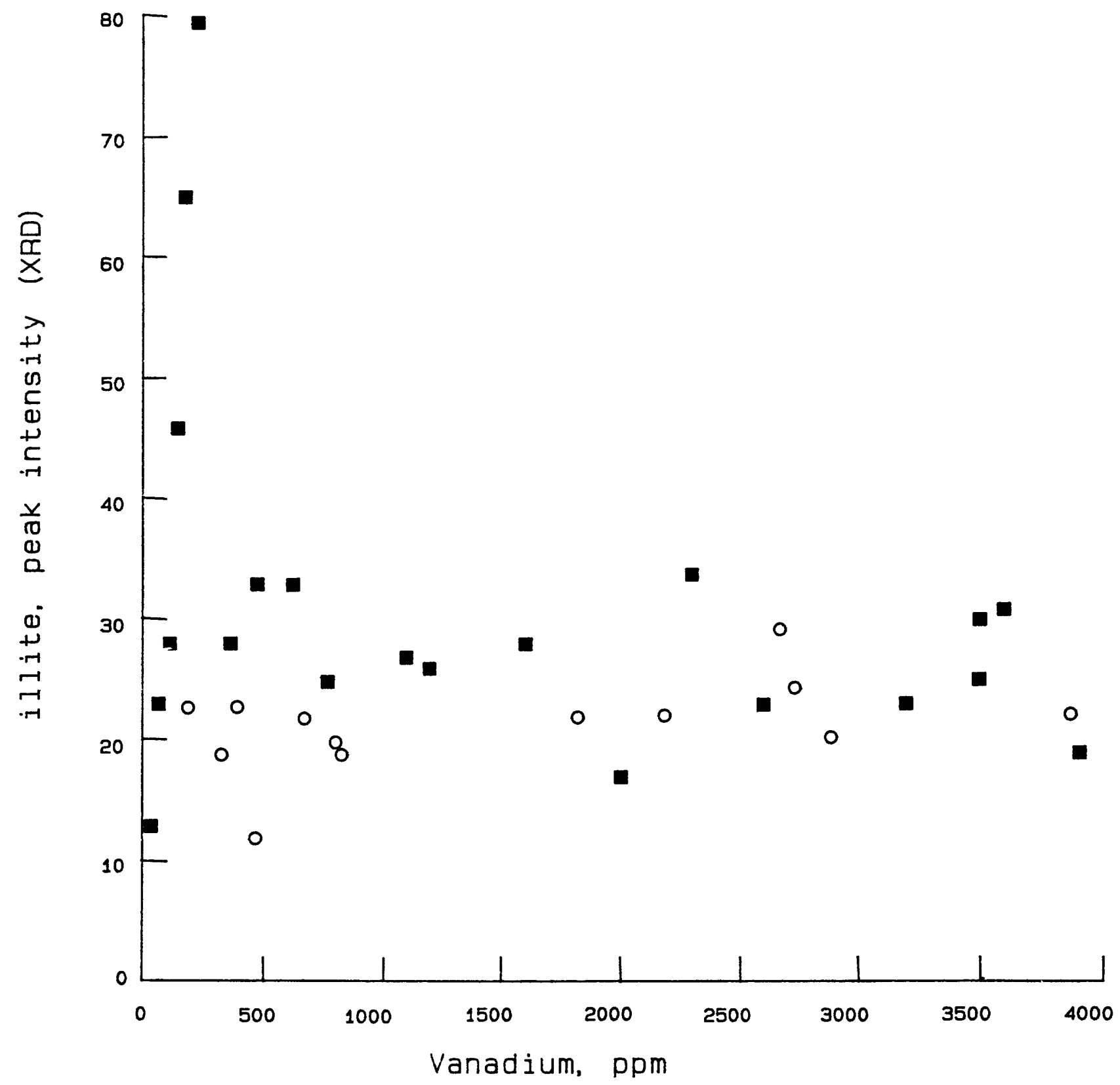

Figure 4. Relations between illite peak intensity and content of vanadium for samples of the Stark Shale Member (solid squares), Wabaunsee County, Kansas, and for samples of the Mecca Quarry Shale Member and equivalents in the Midcontin (open circles). Vanadium values for the Mecca Quarry and equivalents are from Coveney and others (1987, table 2).

The ubiquitous occurrence of iron-rich chlorite in these strata and the less common presence of siderite reflects the presence of iron that is not in sulfide. Gypsum, which is present in fresh core samples, contributes significantly to the total sulfur content. The quality of X-ray diffraction data for samples of the Stark Shale Member studied here is indicated by a very high correlation $(r=0.92)$ between the apatite peak intensity and the content of phosphorous.

Chemical data alone cannot be used to determine the proportions of marine versus humic organic matter or the relative degree of oxidation of these two types of material. Nevertheless, general trends exist in the metal/TO ratios of the so-called near-shore versus offshore shales as shown in table 7. The Stark Shale Member (offshore) has considerably higher metal/TOC ratios for $\mathrm{V}, \mathrm{Zn}, \mathrm{Cd}, \mathrm{Ni}$, and $\mathrm{Cr}$. These higher ratios may be related to factors such as salinity and $\mathrm{pH}$, degree of oxidation of organic matter, or type of organic matter.

For both the Mecca Quarry Shale Member and the Stark Shale Member, Mo, Se, Ni, V, and $\mathrm{Cr}$ are associated with organic matter. 


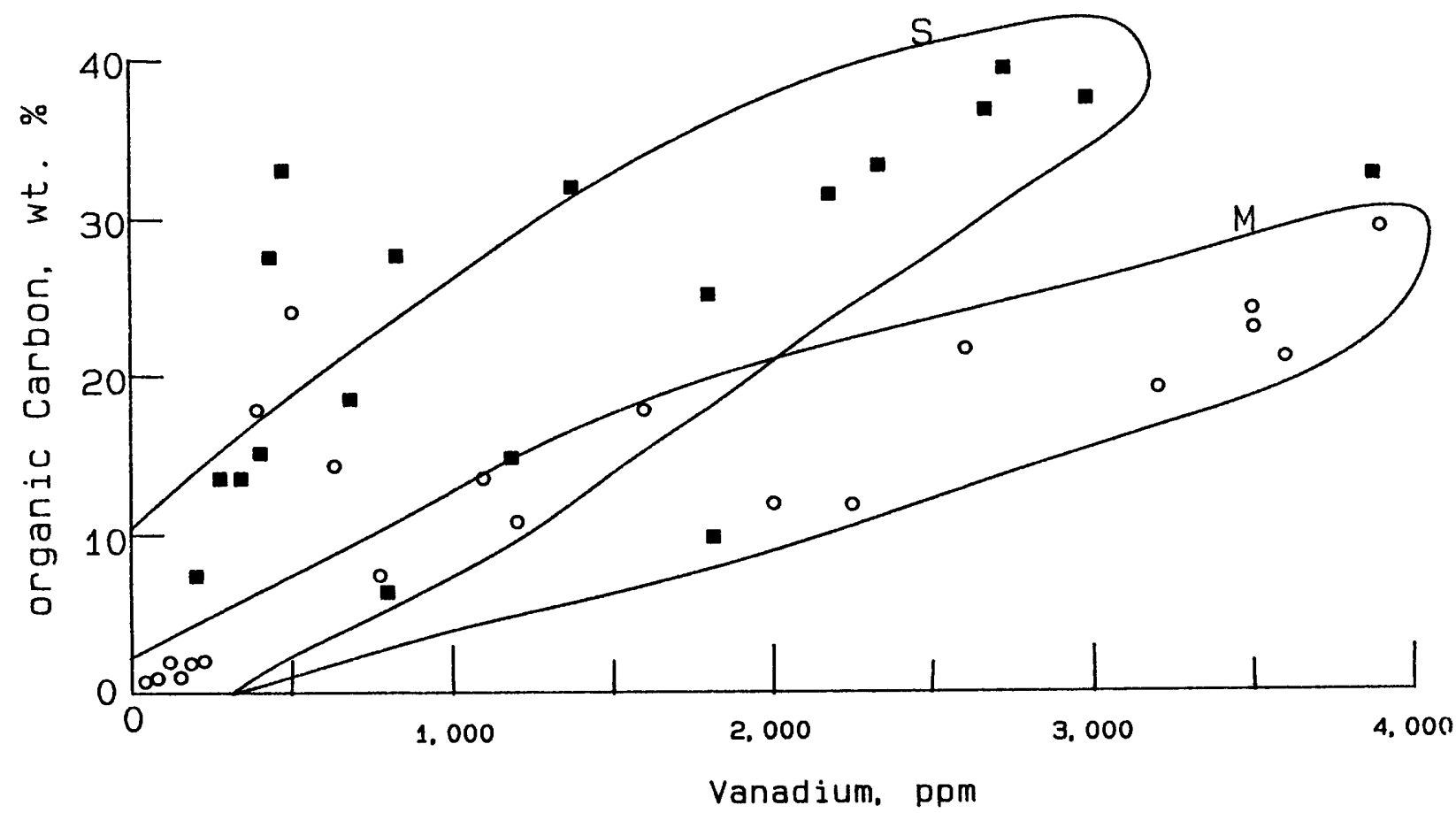

Figure 5. Relations between organic carbon content and content of vanadium for samples of the Stark Shale Member (solid squares), Wabaunsee County, Kansas and for samples of the Mecca Quarry Shale Member and equivalents (open circles) fiom the Midcontinent region. Vanadium values for the Mecca Quarry and equivalents are from Coveney and others (1987, table 2). Line $S$ encloses 18 of 21 Stark samples; line M encloses 7 of 11 Mecca Quarry samples.

\section{REFERENCES CITED}

Beier, J.A., and Hayes, J.M., 1989, Geochemical and isotopic evidence for paleoredox conditions during deposition of the Devonian-Mississippian New Albany Shale: Geological Society of America Bulletin, v. 101, p. 774-782.

Carroll, Dorothy, 1970, Clay minerals-A guide to their identification: Geological Society of America Special Paper $126,80 \mathrm{p}$.

Coveney, R.M., Leventhal, J.S., Glascock, M.D., and Hatch, J.R., 1987, Origins of metals and organic matter in the Mecca Quarry Shale Member and stratigraphically equivalent beds across the Midwest: Economic Geology, v. 82, p. 915-933.

Coveney, R.M., and Glascock, M.D., in press, A review of the origins of metal-rich Pennsylvanian black shales, central U.S.A., with an inferred role for basinal brines: Applied Geochemistry, v. 2, p. 543-561.

Desborough, G.A., and Poole, F.G., 1983, Metals in marine black shales of the Western United States: Society of Economic Geologists/American Institute of Mining and Engineering, Cameron Volume on Unconventional Mineral Resources, p. 99-110.

Derkey, P.D., Abercrombie, F.N., Vuke, S.M., and Daniel, J.A., 1985, Geology and oil shale resources of the Heath
Formation, Fergus County, Montana: Montana Bireau of Mines and Geology Memoir 57, $100 \mathrm{p}$.

Heckel, P.H., 1977, Origin of phosphatic black shale frcies in Pennsylvanian cyclothems of mid-continent North A merica: American Association of Petroleum Geologists Pulletin, v. 61 , p. $1045-1068$.

Kline, G. deV., and Willard, D.A., 1989, Origin of the Ponnsylvanian coal-bearing cyclothems of North A merica: Geology, v. 17, p. 152-155.

Leventhal, J.S., 1981, Pyrolysis gas chromatography-ma-s spectrometry to characterize organic matter and its relationship to uranium in Appalachian Devonian shales: Gecchimica et Cosmochimica Acta, v. 45, p. 883-889.

Lichte, F.E., Golightly, D.W., and Lamothe, P.J. 1987, Inductively coupled plasma-atomic emission spectrometry, in Baedecker, P.A., ed., Methods for geochemical analysis: U.S. Geological Survey Bulletin 1770, p. B1-10.

Stanton, M.R., Leventhal, J.S., and Hatch, J.R., 1983, Shcrt-range vertical variation in organic carbon, carbonate carb $>n$, total sulfur contents and Munsell color values in a core from the Upper Pennsylvanian Stark Shale Member of the Dennis Limestone, Wabaunsee County, Kansas: U.S. Genlogical Survey Open-File Report 83-315, 8 p.

Swanson, V.E., 1960, Oil yield and uranium content of black shales: U.S. Geological Survey Professional Paper 356-A, $44 \mathrm{p}$. 
Table 7. Weighted mean and mean and calculated concentration ratios for several metals relative to the organic carbon content for the Mecca Quarry Shale Member of the Carbondale Formation in Illinois and of the Linton Formation in Indiana and the Stark Shale Member of the Dennis Limestone in Wabaunsee County, eastern Kansas

[Weighted mean is the percent of total interval represented by sample $X$ element concentration in sample, summed for total interval. All elements in parts per million except organic carbon $(\mathrm{C}$, org), which is in weight percent]

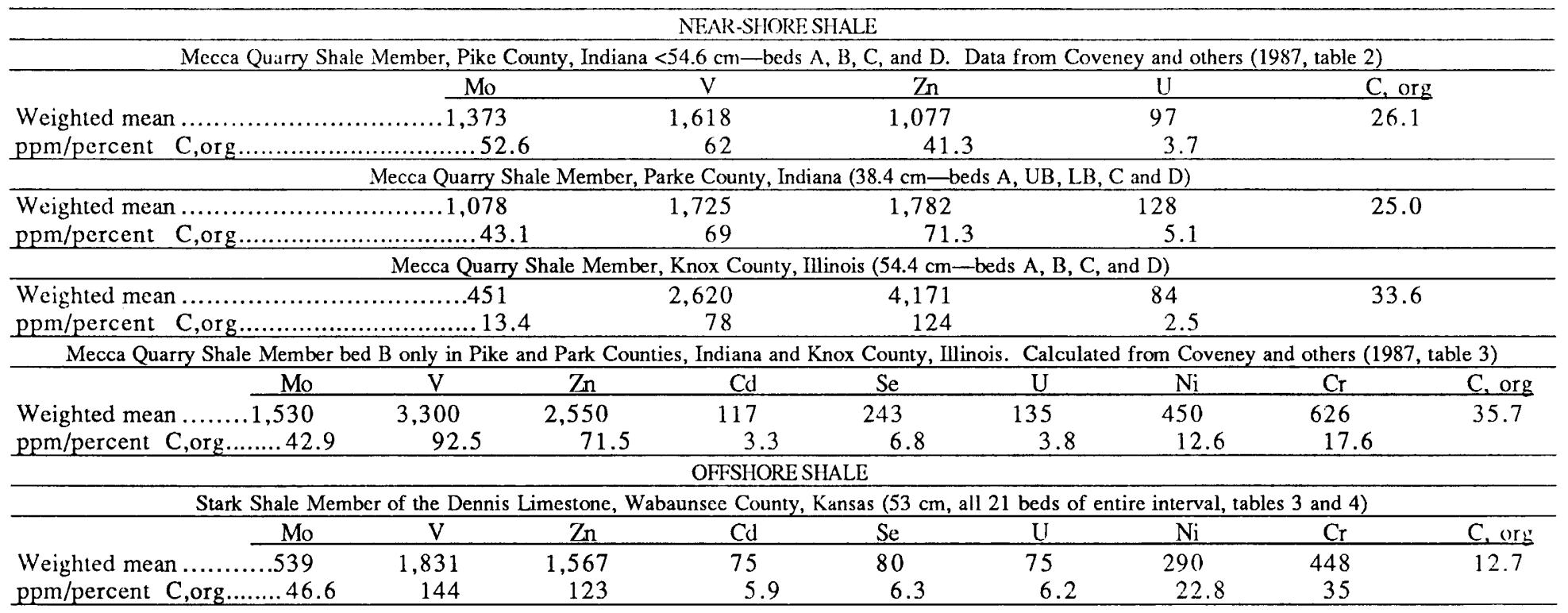




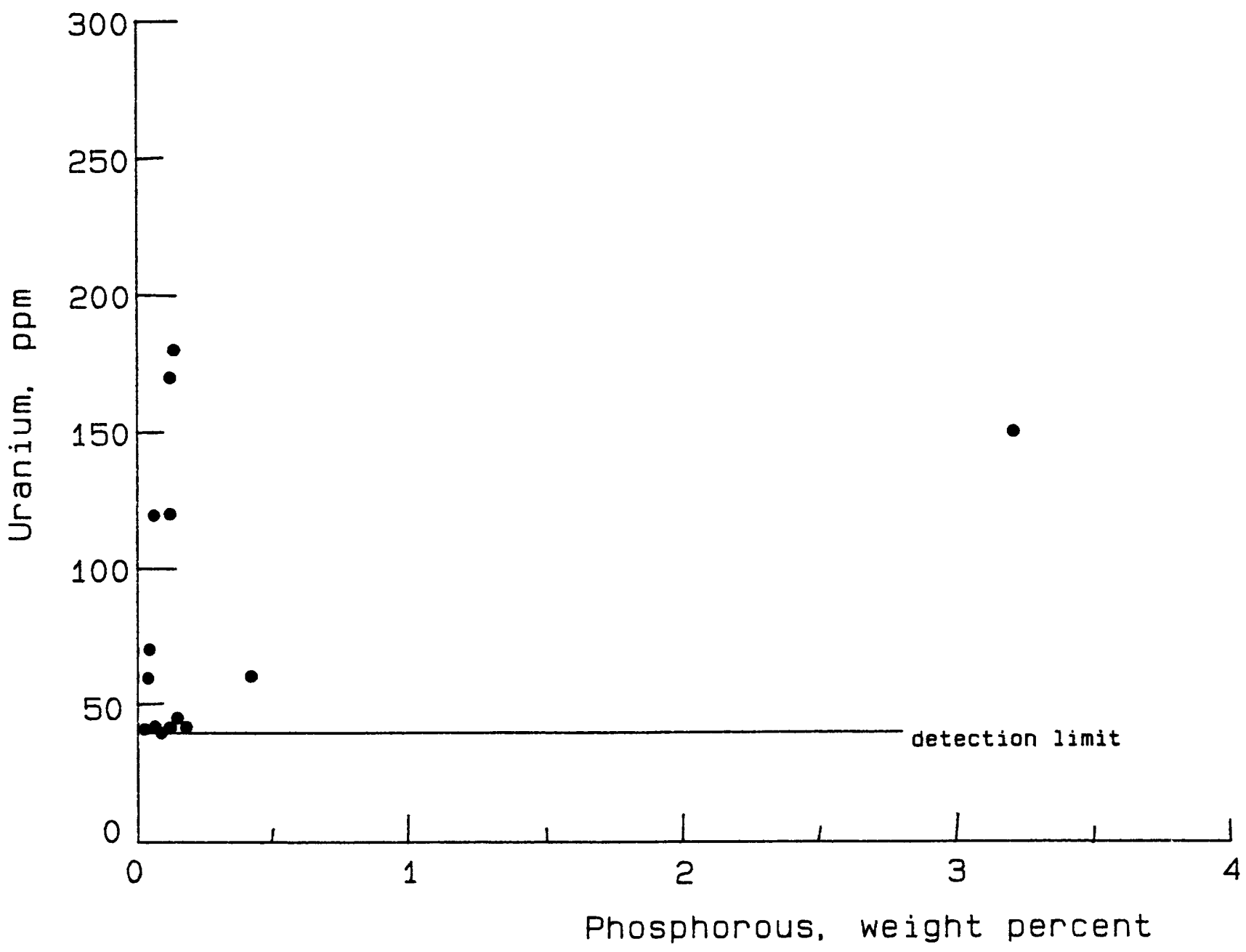

Figure 6. Concentrations of uranium and phosphorous in samples of the Stark Shale Member, Wabaunsee County, l'ansas. 


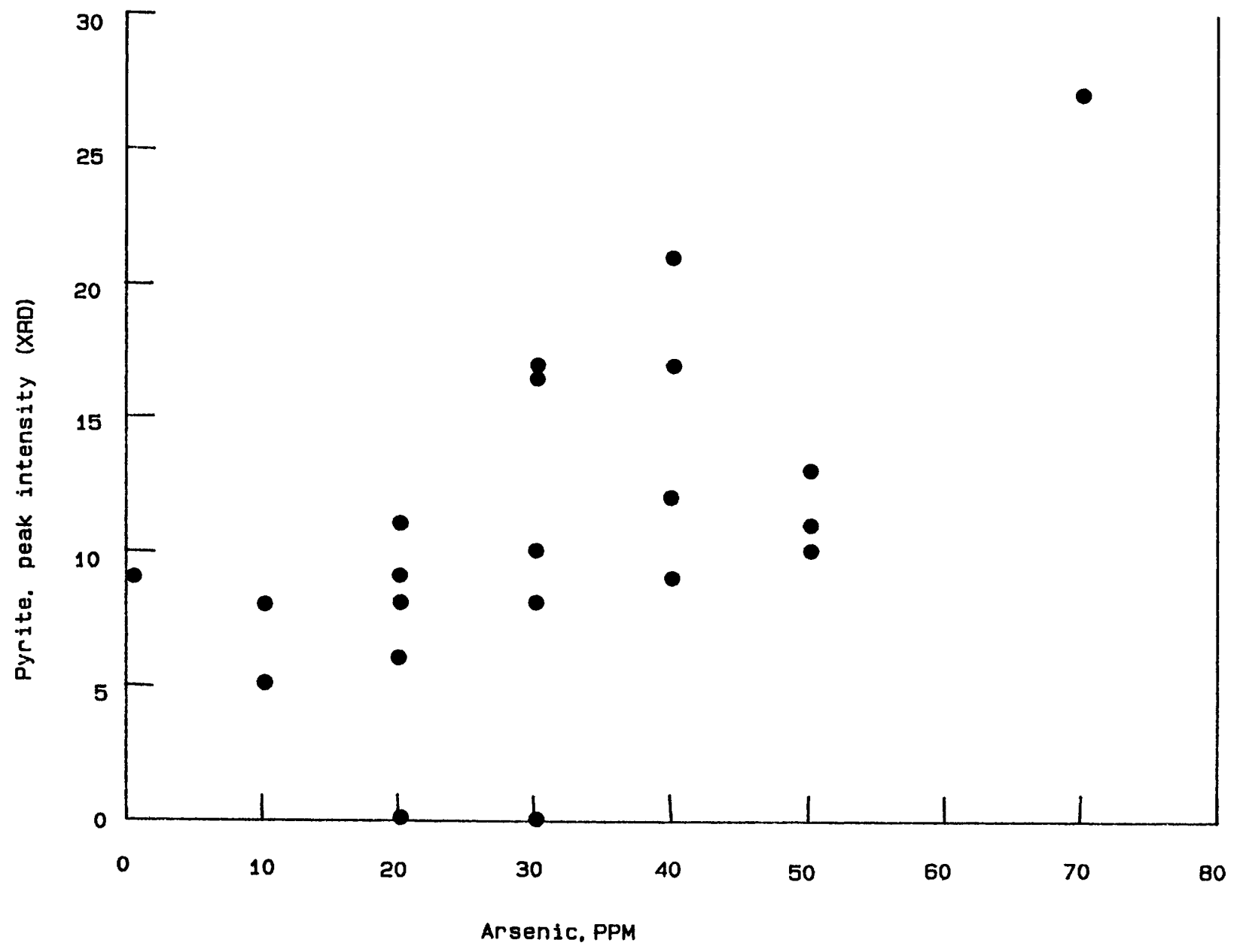

Figure 7. Relations between pyrite peak intensity (py2) and arsenic content for samples of the Stark Shale Member, Wabaunsee County, Kansas. Arsenic values were reported in 10-ppm intervals. 


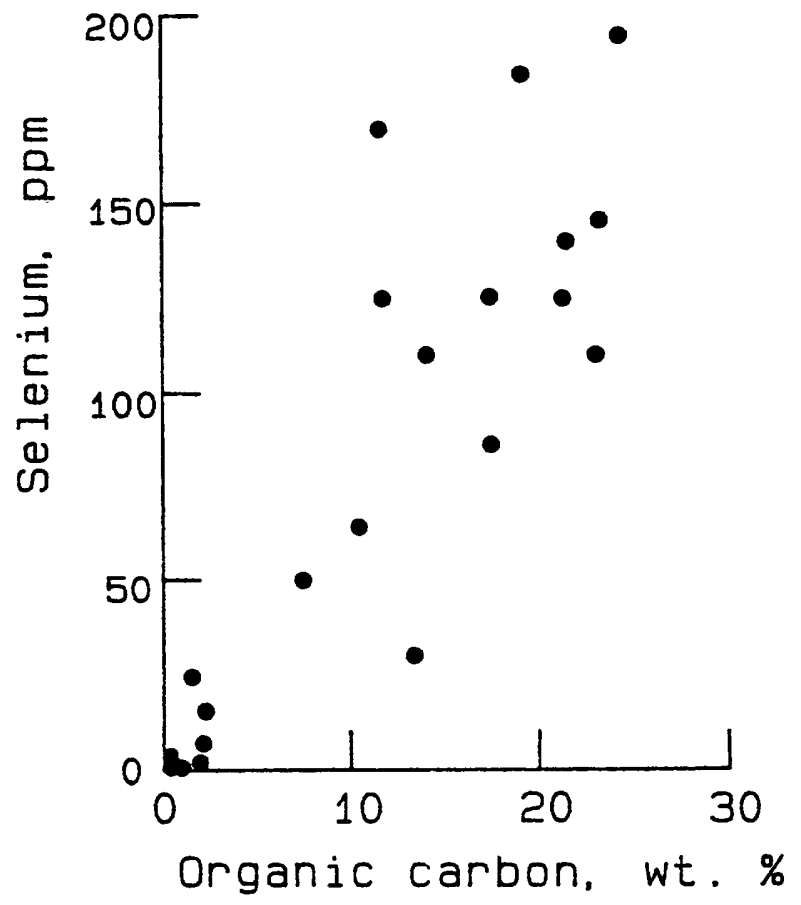

Figure 8. Concentrations of selenium and organic carbon in samples of the Stark Shale Member, Wabaunsee County, Kansas.

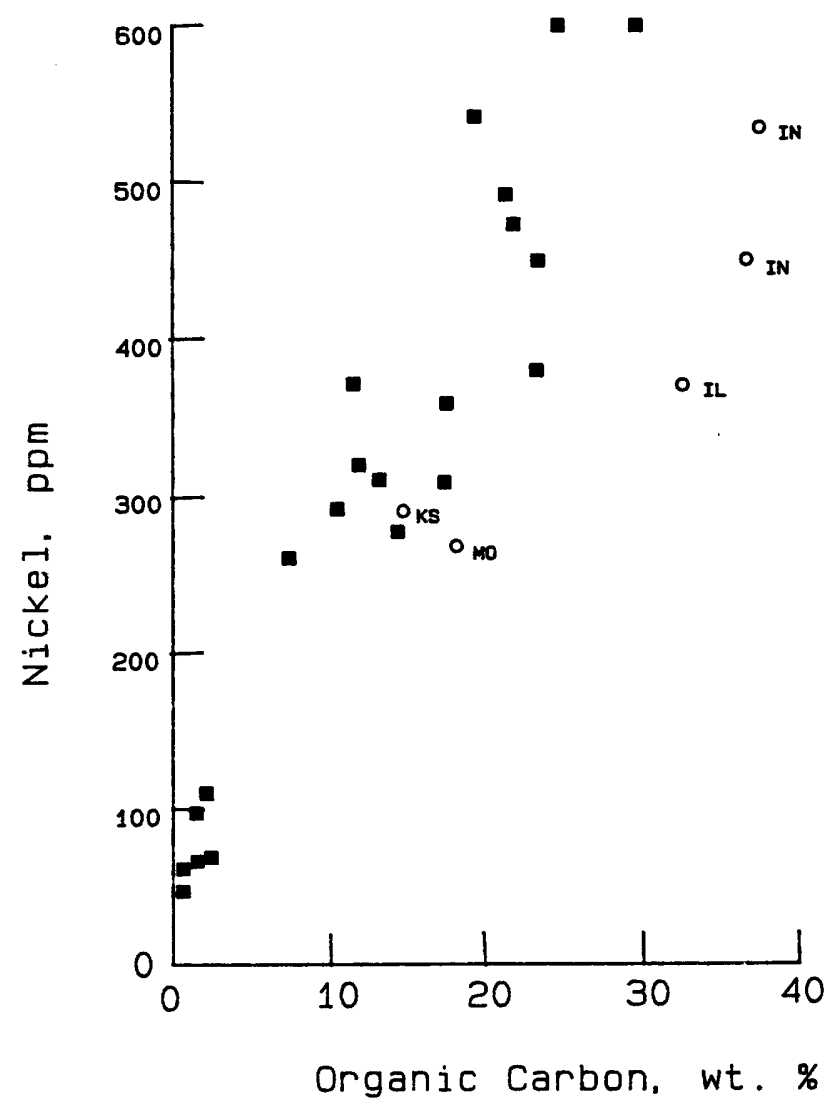

Figure 9. Relations between nickel and organic carbon contents for samples of the Stark Shale Member (solid squares) and Mecca Quarry Shale Member and equivalents of Coveney. and others (1987, table 3) (open circles). IN, Indiana; IL, Illinois; MO, Missouri; KS, Kansas. 


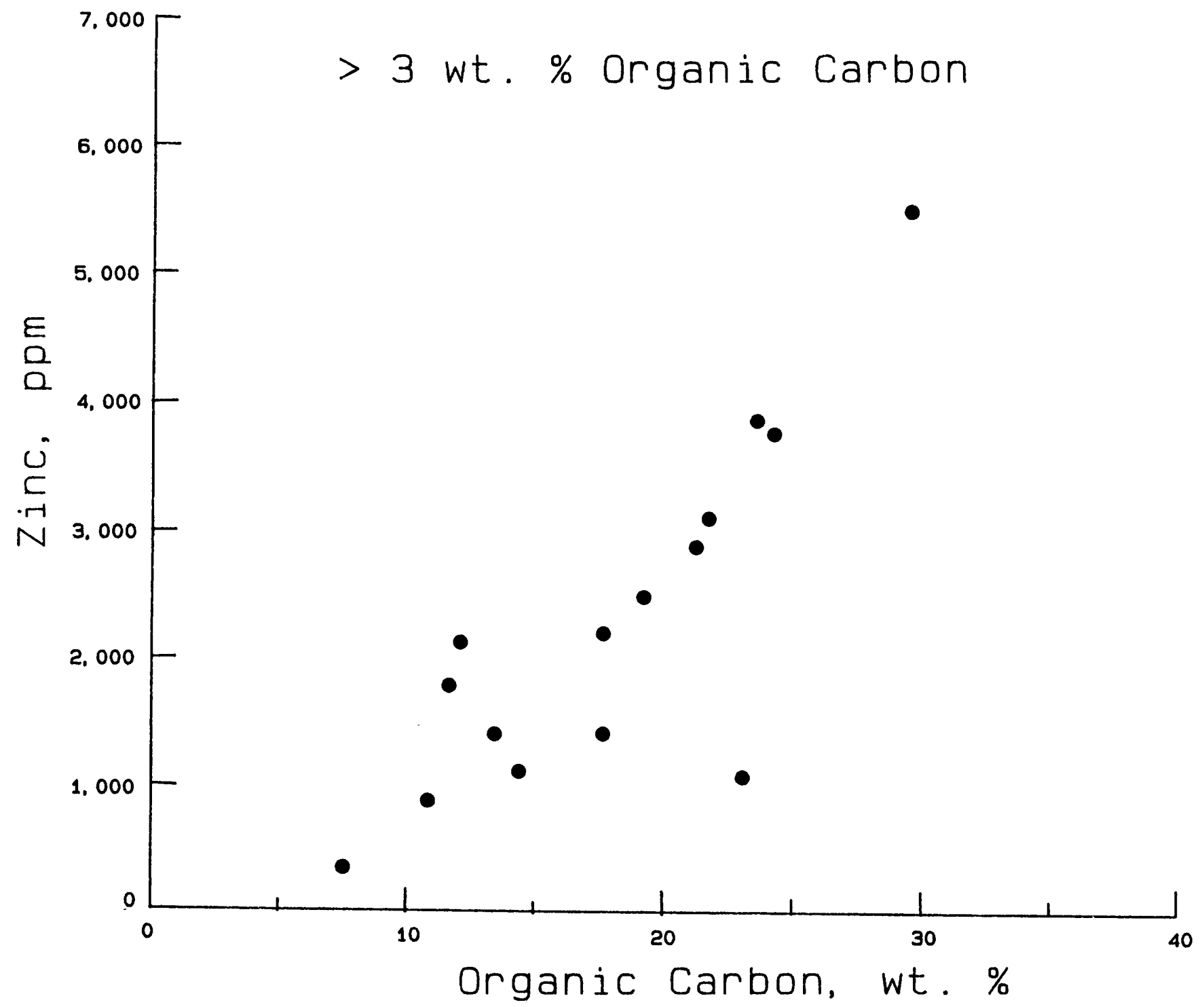

Figure 10. Relations between organic carbon and zinc contents for samples of the Stark Shale Member, Wabaunsee County, Kansas, containing more than 3 weight percent organic carbon. 


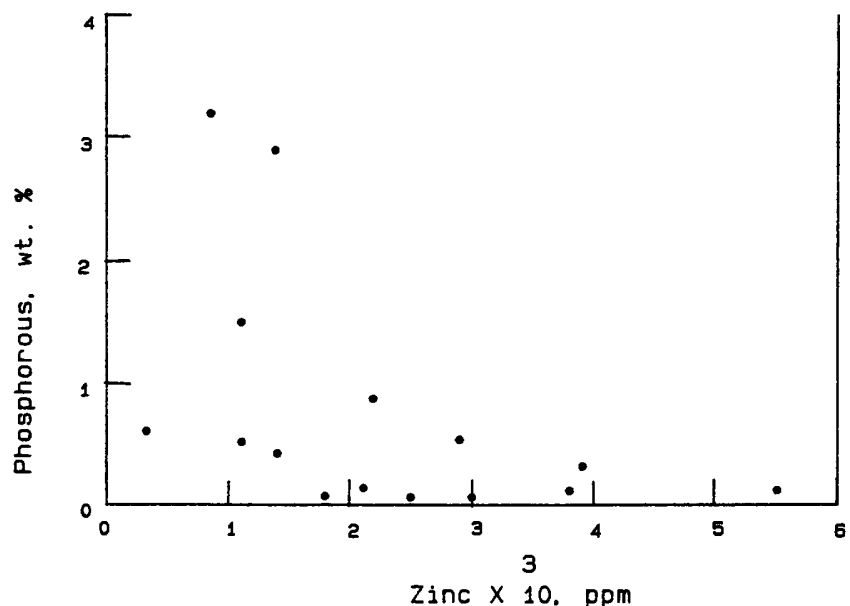

Figure 11. Concentrations of phosphorous and zinc in samples of the Stark Shale Member, Wabaunsee County, Kansas, containing more than 3 weight percent organic carbon.

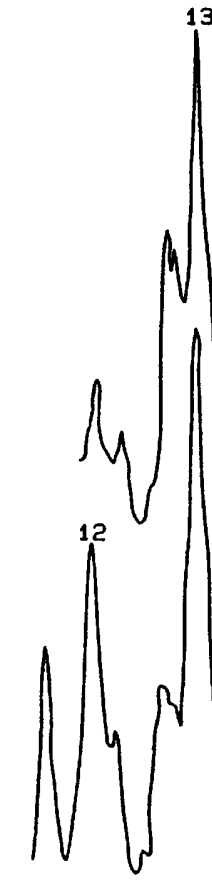

$\left.\right|^{13} \ln$

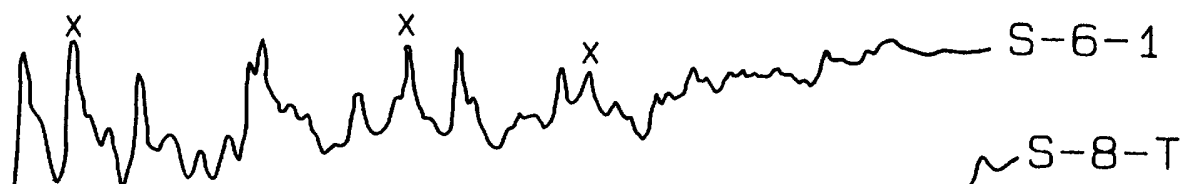<smiles>C1CCC(CC2CCCC2)C1</smiles> 


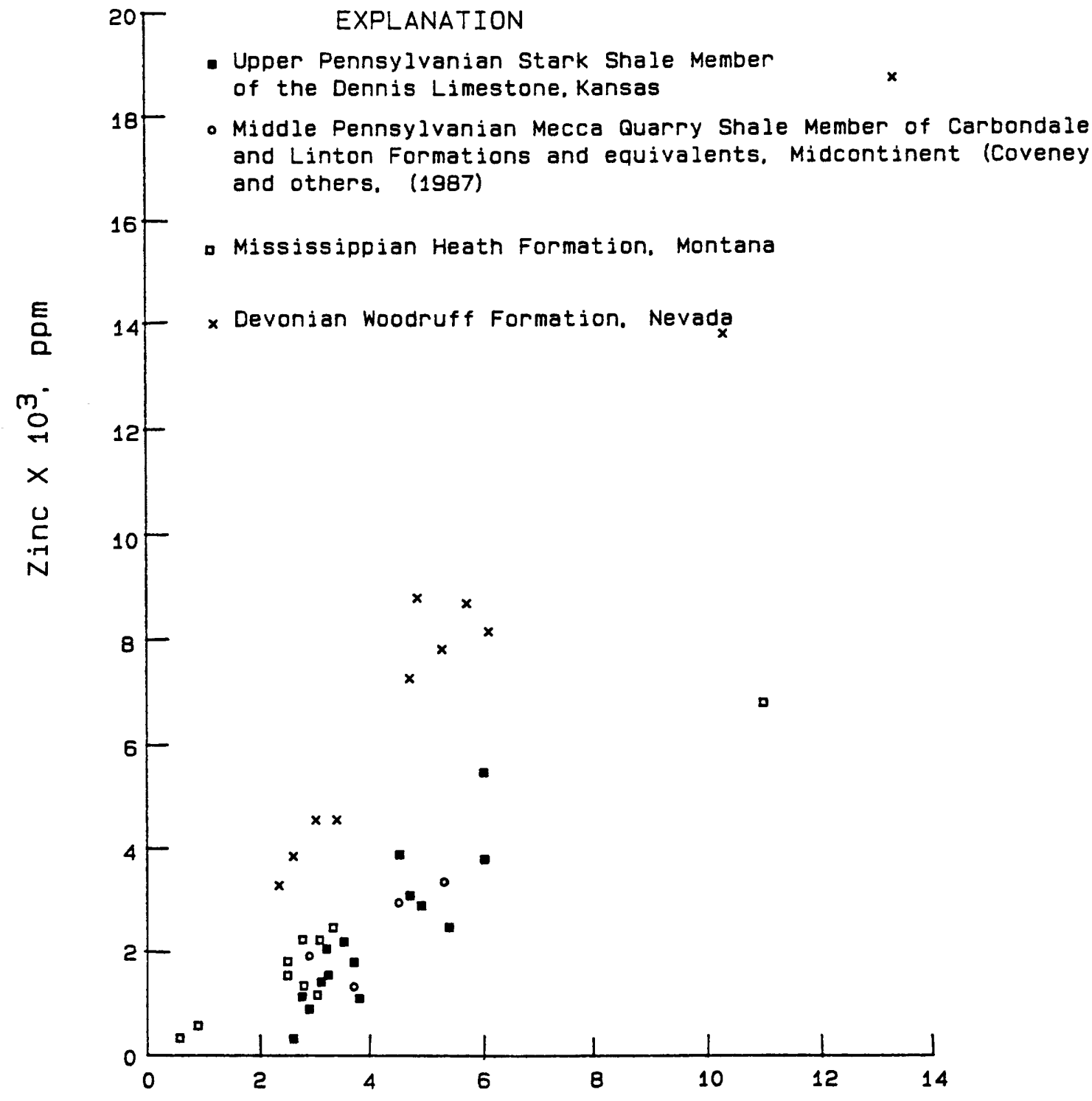

Nickel $\times 10^{2}, \mathrm{ppm}$

Figure 13. Relations between zinc and nickel contents of Devonian, Mississippian, and Pennsylvanian marine shales containing more than 3 weight percent organic carbon. Mecca Quarry Shale Member and equivalents c'ata from Coveny and others (1987); Heath Formation data from Derkey and others (1985); Woodruff Formation c'ata from Desborough and Poole (1983). 


\title{
Organic Ligands and Metal-Organic Complexing in Ore Fluids of Sedimentary Origin
}

\author{
By Thomas H. Giordano'
}

\begin{abstract}
A variety of chemical models have been developed during the past 50 years to describe the genesis of those ores linked to diagenetic processes within sedimentary basins (classic Mississippi Valley-type deposits; early-rift deposits; metal-rich shale deposits; and copper-lead-, and uraniumsandstone deposits). Recently, efforts have been initiated by several investigators to study metal-organic complexing as a means of metal transport in ore fluids responsible for these types of deposits, in particular Mississippi Valley-type ore solutions. Although many of the aqueous organic species detected in modern sedimentary basins are capable of forming metal-organic complexes, the most promising organic ligands detected in deep sedimentary basin waters are acetate, oxalate, malonate, and succinate. For some important rockforming and ore-forming metals, thermodynamic data now exist for acetate complexes in the range $25-300^{\circ} \mathrm{C}$; however, the data base for complexes of acetateand other ligands is deficient, in that data are available mostly for temperatures near $25{ }^{\circ} \mathrm{C}$ for many metal-acetate complexes and for most complexes involving other possibly important organic ligands. Speciation models for metal-organic complexes in a hypothetical sedimentary basin brine and in reconstructed Mississippi Valley-type ore solutions have been developed based on high-temperature thermodynamic data for acetate complexes of $\mathrm{Na}^{+}, \mathrm{Zn}^{2+}, \mathrm{Fe}^{2+}, \mathrm{Pb}^{2+}$, and $\mathrm{Al}^{3+}$; lowtemperature data (near $25{ }^{\circ} \mathrm{C}$ ) for acetate complexes of competing metals, oxalate complexes, malonate complexes, succinate complexes, and catechol complexes; and the available thermodynamic data on chloride, carbonate, sulfate, and hydroxide complexes. These models suggest that acetate complexes and to a lesser extent complexes involving oxalate, malonate, succinate, and catechol can account for significant percentages of dissolved $\mathrm{Ca}, \mathrm{Mg}, \mathrm{Pb}, \mathrm{Zn}, \mathrm{Fe}$, and $\mathrm{Al}$ in oxidized and slightly acid basinal brines and ore fluids having similar chemistry. The basinal brine model presented in this paper shows that metal-organic complexes may be important in transporting lead, zinc, and other metals in warm, oxidized ore fluids similar to those proposed elsewhere for red-
\end{abstract}

\footnotetext{
${ }^{1}$ Department of Earth Sciences, New Mexico State University, Las Cruces, New Mexico 88003.
}

bed-related copper- rich shales. Future efforts to produce reliable ore transport and deposition models for $s: d i m e n t-$ hosted deposits must focus on the procurement of wellconstrained geochemical parameters as v'ell as comprehensive and reliable thermodynamic data.

\section{INTRODUCTION}

The formation and migration of petroleum and natural gas have been extensively investigated during the past $\mathbf{5 0}$ years, and it is now widely accepted that these commodities were formed by diagenetic processes related to th evolution of sedimentary basins (Tissot and Welte. 1984). Sedimentary basins and related diagenetic procerses can also be unequivocally linked to the genesis of lc $\mathrm{N}$-grade metal-rich black shales (Tourtelot, 1979) and sorne basemetal and uranium deposits (Amstutz and Bernard, 1976; Wolf, 1976; Bjorlykke and Sangster, 1981; Gustafson and Williams, 1981; Nash and others, 1981). In table 1 are listed five major deposit-types that are typically hosted by cratonic, basinal sedimentary rocks and that are thought to be formed by hydrogeochemical processes with in sedimentary basins. A variety of geochemical models have been developed to describe the genesis of these ores (Rose, 1976; Tourtelot, 1979; Byorlykke and Sangster, 1981; Gustafson and Williams, 1981; Nash and others, 1981; Maynard, 1983; Sverjensky, 1986, 1987; Coveney and Glascock, 1989; Vaughan and others, 1989). In many of these models, metal transport is dominantly by some mechanism involving inorganic complexes, whereas metal deposition is caused by epigenetic or indigenous organic matter (including micro-organisms). During the past 10 years, efforts have been initiated by a small number of invertigators to study the importance of organic matter as a means of metal transport in ore fluids, in particular, Mirsissippi Valley-type (MVT) ore solutions (Giordano and Barnes, 1981; Giordano, 1985; Drummond and Palme-; 1986; Kharaka and others, 1987; Hennet and others, 19?8; Gize and Barnes, 1989). Progress, however, has been slow in developing satisfactory ore fluid models that incluce metal- 
organic complexing. The principal reason for this slow progress can be attributed to a lack of information on (1) the chemical and physical constraints of ore-forming environments, especially $\mathrm{pH}$ and oxidation state, (2) the nature and concentration of organic ligands in ore-forming environments, and (3) the thermodynamic properties of pertinent metal-organic complexes.

In this paper I present a brief status report on current knowledge about the role of metal-organic complexing in the genesis of MVT deposits and related shale-hosted deposits. Hopefully, this knowledge will encourage researchers in their efforts to evaluate the genetic role of metal-organic complexes in the formation of all basinrelated metal-rich deposits. First, I briefly discuss how organic ligands are produced in the diagenetic environment and what their observed concentrations are in modern sedimentary basin waters. Next, I comment on the availability of thermodynamic data sets for metal-organic complexes and I evaluate the importance of organic ligands as metal-transporting agents in several proposed MVT ore fluid models. Finally, I discuss the possible importance of organic ligands as metal-transporting agents in ore fluids for shale-hosted and red-bed-related deposits.

\section{ORGANIC LIGANDS}

The source of organic ligands in a basinal ore fluid can be directly linked to the nature and transformation of organic matter within the sedimentary basin. Many complex and simple interactions lead to diagenetic transformations of this organic matter (Tissot and Welte, 1984; Kharaka and others, 1985; Lundegard and Kharaka, 1990). Some of the more important diagenetic processes are presented on figure 1. On this figure, the progressive diagenetic changes in solid organic matter (middle column) and the nature of dissolved organic material in the pore water (right column) are shown as a function of depth interval in which transformations are initiated. If basinal pore waters represent potential ore fluids that through time evolve toward specific ore fluids during diagenesis, then it is likely that organic acid ions, phenols, thiols, and organic sulfides (fig. 1, right column) are among the more important organic ligands in these evolving ore fluids.

A rough correlation between sediment depth on figure 1 and deposition temperature in table 1 provides a means of predicting which organic ligands should be expected in specific types of ore fluids. In table 1 , the deposition temperature for a specific deposit type is probably similar to the maximum temperature of water-rock interaction for the corresponding evolving ore fluid. These pore waters, which probably have their source far from the site of deposition, scavenge organic ligands and metals from their source sediments as well as from rocks along the path of migration to the site of deposition. A potential ore fluid can migrate from or through the hotter parts of the basin. In both cases,

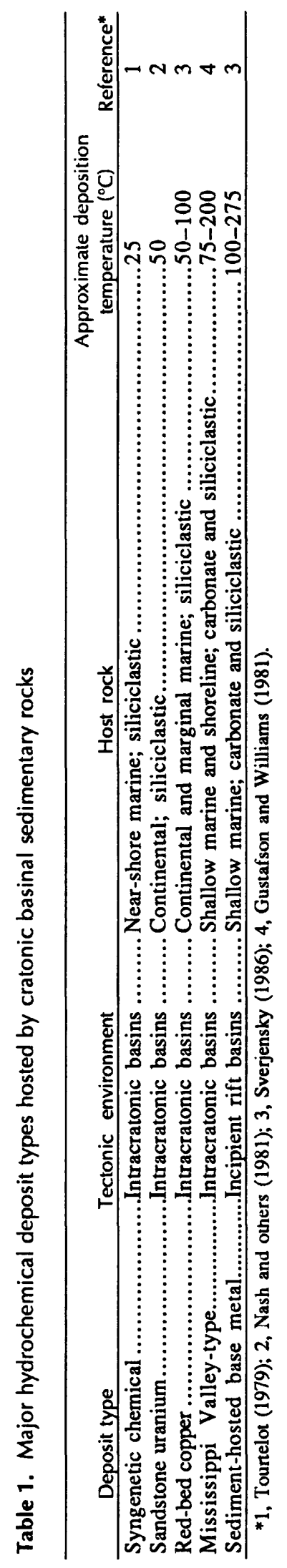




\section{GENERATION AND DIAGENESIS OF KEROGEN}

Sediment depth

Onset of transformations

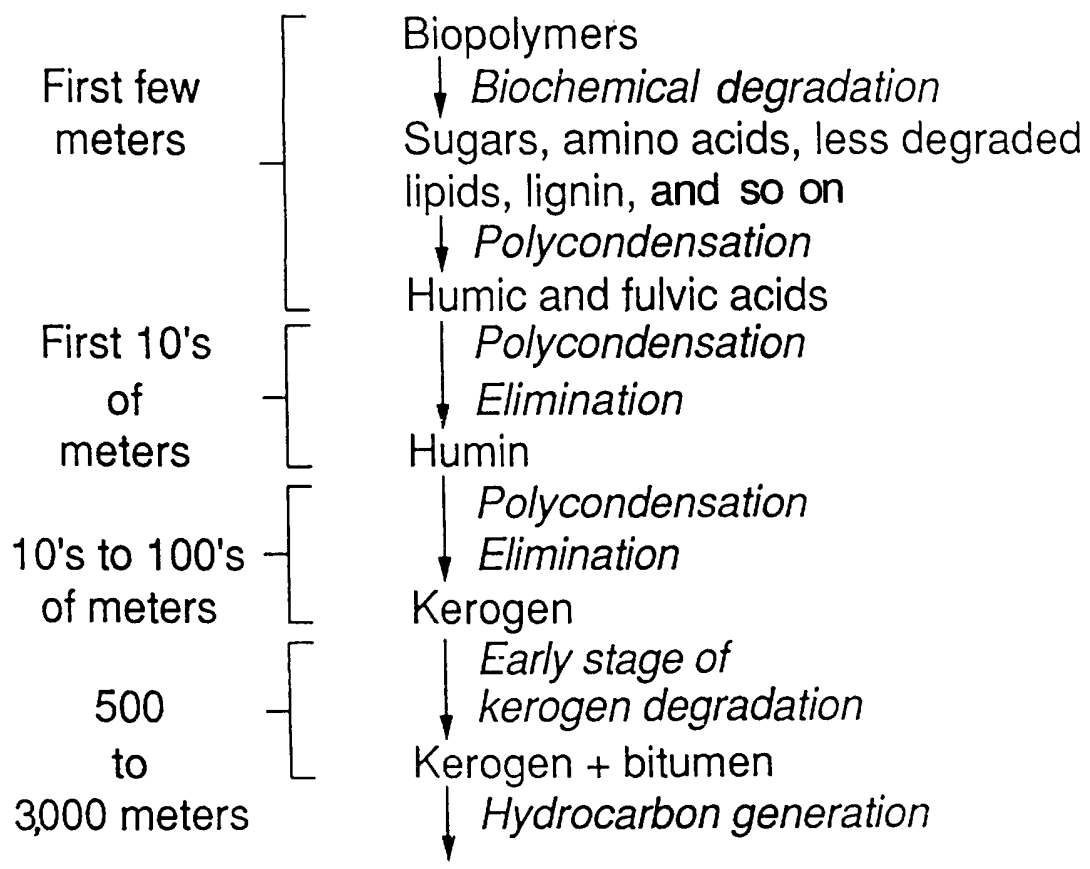

Dissolved species

In pore water

\author{
Sugars, amino acids, \\ fulvic acids , \\ humic acids \\ $\mid \begin{aligned} & \text { Fulvic and humic acids, } \\ & \mathrm{NH}_{3}\end{aligned}$
} Fulvic and humic acids,
carboxylic acids
carboxylic acids,
phenols, thiols, sulfides,
thiophenes, $\mathrm{CO}_{2}, \mathrm{H}_{2} \mathrm{O}$,
hydrocarbons

Figure 1. Formation and diagenesis of organic matter in sediments as a function of depth.

the composition of dissolved organic matter in the ore fluid should be strongly influenced by reactions at the highest temperatures attained. For example, molecules of amino, humic, and fulvic acids (fig. 1) should be the dominant organic ligands in "cold" (less than about $50^{\circ} \mathrm{C}$ ) ore fluids (table 1) evolved at depths of less than about $1,000 \mathrm{~m}$. Carboxylic acid ions, phenols, and organic sulfur species should be the dominant organic ligands produced, along with hydrocarbons and other products of kerogen degradation, in "hydrothermal" (greater than about $50^{\circ} \mathrm{C}$ ) ore fluids evolved from deep-basinal pore waters.

Analyses of dissolved organic matter in subsurface waters confirm the above speculations. For example, fulvic and humic acids are the dominant organic constituents in surface waters and cold interstitial waters of shallow sediments. Lesser amounts of amino acids and carbohydrates are also found as dissolved constituents in these waters (Stumm and Morgan, 1981; Thurman, 1985). Because molecules of humic substances and amino acids form strong complexes with metals, they may contribute significantly to metal transport in cold ore solutions (sandstone uranium deposits, syngenetic metal-rich shales and possibly red-bed copper deposits); however, these ligands have a low thermal stability and are not likely to be important in ore fluids having temperatures much greater than $50^{\circ} \mathrm{C}$ (Giordano, 1985).
Various carboxylic acid ions are also fourd in cold surface and subsurface waters where they alway's form a minor component of the dissolved organic matter. In deepbasinal pore waters, however, carboxylic acid ions are the dominant dissolved organic constituents (Surdam and others, 1984; Kharaka and others, 1985; Hanor and Workman, 1986; Fisher, 1987; MacGowan and Surdam, 1988; Fisher and Boles, 1990). As shown in table 2, acetate generally dominates in these waters and is followed in level of concentration by longer chained aliphatic acid ions. Some deep-basinal waters contain high concent ations of dicarboxylic acid ions, especially oxalate, malc nate, and succinate (table 2). Dissolved phenolic compounc's are also known to be present in deep sedimentary basin waters, but their concentrations are not well established (Kharaka and others, 1985; Fisher and Boles, 1990). To my knowledge, thiols and other dissolved organic sulfur species have not been identified in deep formation waters. T"e above evidence suggests that acetate, oxalate, malonate. and succinate may be important organic ligands in certc in hydrothermal basinal ore solutions. These acid ions form moderately strong metal-organic complexes and probably are at least moderately metastable under hydrothermal conditions. (Kharaka and others, 1983; Drummond and Palmer, 1986; Lundegard and Kharaka, 1990). 
Table 2. Dissolved organic ligands detected in sedimentary basin brines-aliphatic acid anions

[NA indicates data not available, ND indicates not determined]

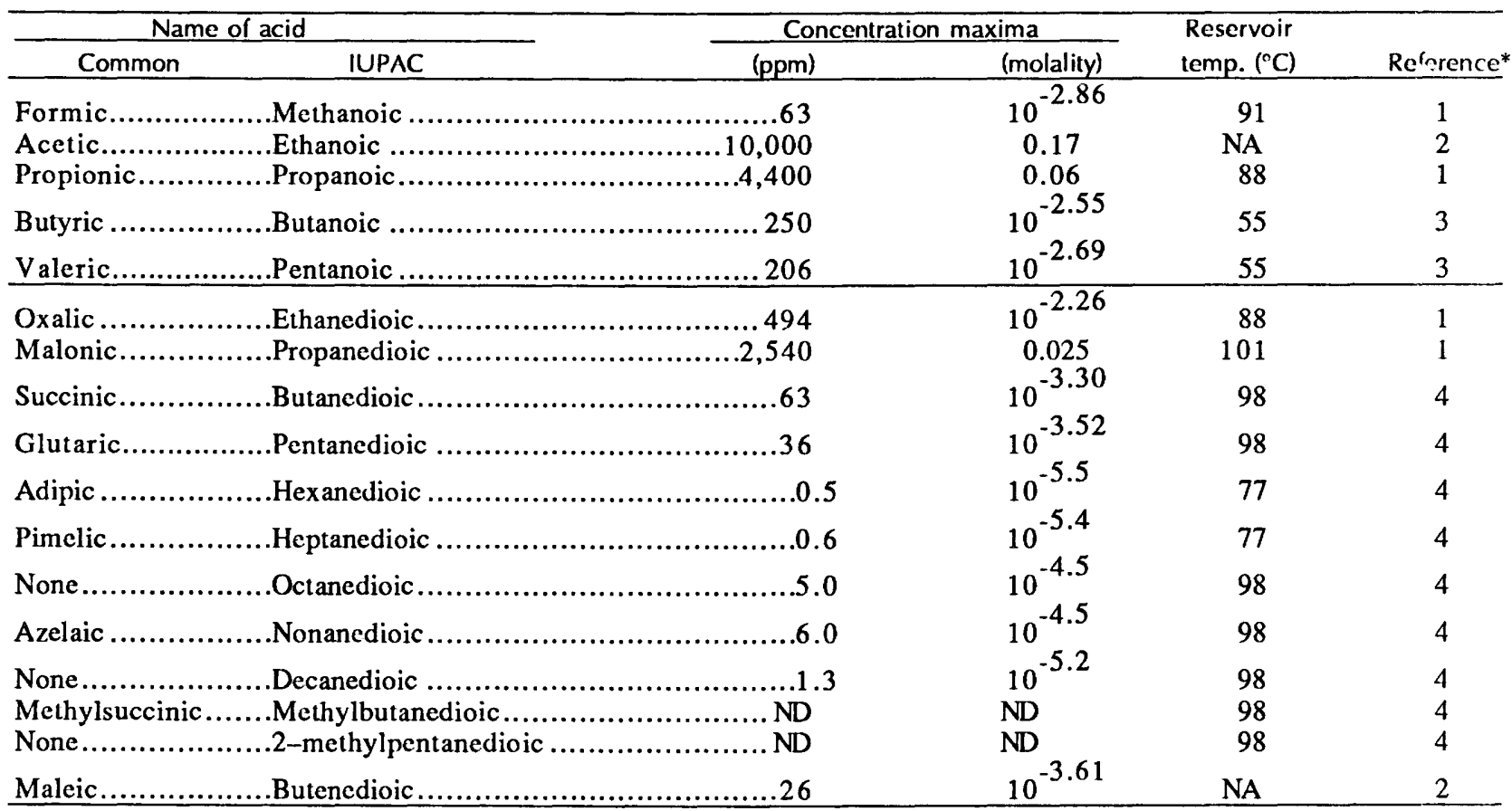

*1, MacGowan and Surdam (1988); 2, Surdam and others (1984); 3, Fisher (1987); 4, Kharaka and others (1985).

\section{THERMODYNAMIC DATA}

To evaluate the importance of a particular metalorganic complex in ore fluids and formation waters, the theoretically estimated concentration of that species in solution must be determined by calculation. Three types of information are required to perform such a calculation: (1) chemical and physical parameters of the solution and its surrounding geochemical environment, (2) stoichiometry of all possibly important aqueous and nonaqueous species, and (3) thermodynamic data for all possibly important aqueous complexes. The latter two categories will be discussed first, with specific reference to metal-organic complexes, and the first category will be considered in the next section.

A large body of thermodynamic data is available in the form of stability constants at temperatures of about 25 ${ }^{\circ} \mathrm{C}$ for metal-organic complexes involving the following ligands: acetate, oxalate, malonate, succinate, and amino acid ions (Martell and Smith, 1977, 1982). Approximate stability constants are also available for some humic and fulvic acid complexes for temperatures near $25^{\circ} \mathrm{C}$. These low-temperature data are sufficient to adequately model speciation in cold ore fluids if all other pertinent data and information are available. To accurately calculate speciation in hydrothermal fluids, thermodynamic data at the specified hydrothermal temperature are required. At present, hightemperature data are available for acetate complexes of some rock-forming and ore-forming metals (table 3). For most other metal-organic complexes of interest, data are available only at temperatures near $25^{\circ} \mathrm{C}$ (Martell and Smith 1977, 1982). The speciation models presented in the next section were developed using high-temperature thermodynamic data for acetate complexes of $\mathrm{Zn}^{2+}, \mathrm{Fe}^{2+}, \mathrm{Pb}^{2+}$, $\mathrm{Na}^{+}$, and $\mathrm{Al}^{3+}$; low-temperature data (about $25^{\circ} \mathrm{C}$ ) for acetate complexes of $\mathrm{Ca}^{2+}$ and $\mathrm{Mg}^{2+}$, oxalate complexes, malonate complexes, succinate complexes, and catechol complexes; and available thermodynamic data on chloride, carbonate, sulfate, and hydroxide complexes.

\section{MISSISSIPPI VALLEY-TYPE ORE SOLUTIONS}

Concentrations of $\mathrm{Ca}, \mathrm{Mg}, \mathrm{Na}, \mathrm{Fe}, \mathrm{Al}, \mathrm{Pb}$, and $\mathrm{Zn}$ as acetate, oxalate, malonate, succinate, and catecrol complexes have been calculated for three reconstructed MVT ore solutions at $100{ }^{\circ} \mathrm{C}$. The results for lead and zinc are shown in table 4. The three reconstructed (model) ore solutions are described in terms of $\log \mathrm{a}_{\mathrm{O}_{2}}$ and $\mathrm{pH}$ on figure 2. In the model proposed by Anderson (1975), the ore fluid is oxidized and plots well above the sulfide-sulfate boundary. It is slightly acid and contains $10^{-2}$ molal total sulfur, principally in the form of $\mathrm{SO}_{4}{ }^{2-}$, with reduced sulfur concentrations well below $10^{-5}$ molal. The ore solution proposed by Giordano and Barnes (1981) is redrced and plots well below the sulfide-sulfate boundary. It is slightly alkaline and contains $10^{-2}$ molal total sulfur, principally as bisulfide. In the model proposed by Sverjensky (1984), the 
Table 3. Stability constants for selected metal-acetate complexes-Temperature range of experimental data

\begin{tabular}{|c|c|c|}
\hline Reaction & $\begin{array}{l}\text { Temperature } \\
\text { range }\left({ }^{\circ} \mathrm{C}\right)^{1}\end{array}$ & References \\
\hline $\mathrm{H}^{+}+\mathrm{Ac}^{-}=\mathrm{HAc}$ & $25-50$ & $\begin{array}{l}\text { Ellis (1963), Lown and others (1970), Fisher and Barnes (1972), Oscarson } \\
\text { and others (1988), Mesmer and others (1989). }\end{array}$ \\
\hline $\mathrm{Na}^{+}+\mathrm{Ac}^{-}=\mathrm{NaAc}$ & $18-310$ & Noyes (1907), Fisher and Barnes (1972), Oscarson and others (1988). \\
\hline $\mathrm{Ca}^{2+}+\mathrm{Ac}^{-}=\mathrm{CaAc}^{+}$ & 25 & Martell and Smith $(1977,1982)$. \\
\hline $\mathrm{Mg}^{2+}+\mathrm{Ac}^{-}=\mathrm{MgAc}^{+}$ & 25 & Martell and Smith $(1977,1982)$. \\
\hline $\mathrm{Fe}^{2+}+\mathrm{Ac}^{-}=\mathrm{FeAc}^{+}$ & $50-300$ & Palmer and Drummond (1988). \\
\hline $\mathrm{Fe}^{2+}+2 \mathrm{Ac}^{-}=\mathrm{FeAc}_{2}$ & $50-300$ & Palmer and Drummond (1988). \\
\hline $\mathrm{Fe}^{2+}+3 \mathrm{Ac}^{-}=\mathrm{FeAc}_{3}^{-}$ & $250-300$ & Palmer and Drummond (1988). \\
\hline $\mathrm{Al}^{3+}+\mathrm{Ac}^{-}=\mathrm{AlAc}^{2+}$ & $25-125$ & Drummond and others (1989). \\
\hline $\mathrm{Al}^{3+}+2 \mathrm{Ac}^{-}=\mathrm{AlAc}_{2}^{+}$ & $75-150$ & Drummond and others (1989). \\
\hline $\mathrm{Pb}^{2+} \mathrm{Ac}^{-}=\mathrm{PbAc}^{+}$ & $25-85$ & Hennet and others (1988), Giordano (1989). \\
\hline $\mathrm{Pb}^{2+}+2 \mathrm{Ac}^{-}=\mathrm{PbAc}_{2}$ & $25-85$ & Hennet and others (1988), Giordano (1989). \\
\hline $\mathrm{Zn}^{2+}+\mathrm{Ac}^{-}=\mathrm{ZnAc}{ }^{+}$ & $25-300$ & Giordano and Drummond (unpublished data). \\
\hline $\mathrm{Zn}^{2+}+2 \mathrm{Ac}^{-}=\mathrm{ZnAc}$ & $25-300$ & Giordano and Drummond (unpublished data). \\
\hline $\mathrm{Zn}^{2+}+3 \mathrm{Ac}^{-}=\mathrm{ZnAc}_{3}^{-}$ & $25-300$ & Giordano and Drummond (unpublished data). \\
\hline
\end{tabular}

ore solution is also reduced, with $\log \mathrm{a}_{0_{2}}-\mathrm{pH}$ conditions just below the sulfide-sulfate boundary. The solution is moderately acid and contains $10^{-5}$ molal total sulfur, principally as $\mathrm{H}_{2} \mathrm{~S}$.

For the three ore-fluid models, several mineral saturation constraints were applied. These are listed in table 5 together with the concentrations of organic ligands used in these models. The concentrations of acetate ( 0.15 molal), oxalate, malonate, and succinate represent the maximum values observed in basinal brines (table 2). The concentration of total catechol $(0.01$ molal $)$ is an arbitrarily chosen value that is in the concentration range reported for oxalate, malonate, and succinate but is well below catechol solubility in water $\left(4 \mathrm{molal}, 25^{\circ} \mathrm{C}\right)$. Although catechol has not been found in oil or gas field brines, Surdam and others (1984) suggested that aluminum catechol complexes may be responsible for significant aluminum mobilization during diagenesis. In all three models, total chloride is approximately 3 molal and the total chloride to total acetate ratio is about 20 to 1 .
The results presented in table 4 shed light on several aspects of lead and zinc transport in the proposed model ore fluids. If the minimum concentrations of lead and zinc required to form an ore deposit are 1-10 ppm (Barnes, 1979), then in model 3 proposed by Giordano and Barnes (1981) sufficient metal cannot be transported by any of the listed complexes. To a lesser extent this is the situation with model 2 (Sverjensky, 1984). In model 1 (Anderson, 1975), however, sufficient zinc and lead can be transported predominantly as chloride complexes. Note alsc that in Anderson's (1975) model (model 1) significant concentrations of lead and zinc are transported as acetate, oxalate, and malonate complexes. In model 2 , chloride ccmplexes are also dominant, and acetate, oxalate, and malonate complexes account for the second largest fraction of lead and zinc. In model 3, bisulfide complexes are by far the dominant species, and all other complexes account for only insignificant amounts of metal in solution.

In all three models, catechol is unable to transport significant amounts of lead and zinc. This follows from the 
Table 4. Calculated concentrations of lead and zinc in proposed Mississippi Valley-type ore fluids [Metal concentrations in parts per million; the minimum concentration required to form an ore deposit is 1-10 ppm (Barnes, 1579)]

\begin{tabular}{|c|c|c|}
\hline $\begin{array}{c}\text { Model } 1 \\
\text { Anderson (1975) } \\
\end{array}$ & $\begin{array}{c}\text { Model } 2 \\
\text { Sveriensky }(1984)^{2} \\
\end{array}$ & $\begin{array}{c}\text { Model } 3 \\
\text { Giordano and Barnes }(1981)^{3}\end{array}$ \\
\hline Total lead .............................. 19.50 & 0.09 & $2.1 \times 10^{-3}$ \\
\hline Lead chloride ........................19.00 & 0.09 & $1.4 \times 10^{-8}$ \\
\hline Lead hydroxide........................ 0.23 & $1.1 \times 10^{-4}$ & $5.4 \times 10^{-9}$ \\
\hline 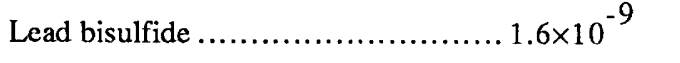 & $4.9 \times 10^{-5}$ & $2.1 \times 10^{-3}$ \\
\hline Lead acetate........................... 0.22 & $8.3 \times 10^{-4}$ & $2.8 \times 10^{-10}$ \\
\hline Lead oxalate......................... 0.014 & $7.9 \times 10^{-5}$ & $2.0 \times 10^{-11}$ \\
\hline Lead malonate........................ 0.014 & $9.3 \times 10^{-5}$ & $1.5 \times 10^{-11}$ \\
\hline Lead succinate........................ $7.2 \times 10^{-5}$ & $7.6 \times 10^{-7}$ & $6.2 \times 10^{-14}$ \\
\hline Lead catechol............................ $4.7 \times 10^{-7}$ & $1.6 \times 10^{-11}$ & $3.3 \times 10^{-13}$ \\
\hline Total zinc............................ 138.0 & 0.68 & $3.1 \times 10^{-3}$ \\
\hline Zinc chloride ...................... 135.0 & 0.68 & $1.0 \times 10^{-7}$ \\
\hline Zinc hydroxide........................ 1.1 & $5.4 \times 10^{-4}$ & $2.5 \times 10^{-8}$ \\
\hline Zinc bisulfide $\ldots \ldots \ldots \ldots \ldots \ldots \ldots \ldots \ldots \ldots \ldots \ldots \ldots . .3 \times 10^{-9}$ & $4.1 \times 10^{-5}$ & $3.1 \times 10^{-3}$ \\
\hline Zinc acetate.............................. 0.44 & $6.0 \times 10^{-3}$ & $4.7 \times 10^{-10}$ \\
\hline Zinc oxalate ........................... 0.28 & $1.4 \times 10^{-3}$ & $4.6 \times 10^{-10}$ \\
\hline Zinc malonate........................... 0.22 & $1.1 \times 10^{-3}$ & $2.2 \times 10^{-10}$ \\
\hline Zinc succinate........................ $3.8 \times 10^{-4}$ & $2.0 \times 10^{-6}$ & $3.6 \times 10^{-13}$ \\
\hline Zinc catechol........................ $6.2 \times 10^{-5}$ & $2.0 \times 10^{-9}$ & $4.6 \times 10^{-11}$ \\
\hline $\begin{array}{l}{ }^{1} \Sigma \mathrm{S}=10^{-2} \mathrm{~m}, \mathrm{pH}=5.7, \log \mathrm{O}_{2}=-50 . \\
{ }^{2} \Sigma \mathrm{S}=10^{-5} \mathrm{~m}, \mathrm{pH}=4.5, \log \mathrm{O}_{2}=-52 . \\
{ }^{3} \Sigma \mathrm{S}=10^{-2} \mathrm{~m}, \mathrm{pH}=7.2, \operatorname{loga} \mathrm{O}_{2}=-55 .\end{array}$ & & \\
\hline
\end{tabular}

law of mass action, which favors $\mathrm{H}^{+}$in the competition for catechol ions within the given $\mathrm{pH}$ ranges of the ore fluids. The competition among cations for organic ligands is an important factor in controlling the speciation in these ore fluids and in all basinal waters. To illustrate the nature of this competition, speciation of $\mathrm{Na}, \mathrm{Ca}, \mathrm{Mg}, \mathrm{Fe}, \mathrm{Al}, \mathrm{Pb}$, and $\mathrm{Zn}$ with the ligands listed in table 5 was calculated for a model sedimentary basin brine at $100{ }^{\circ} \mathrm{C}$ and having a composition similar to the model MVT ore solution of Anderson (1975). The mineral saturation constraints listed in table 5 were assumed in this calculation. The results are presented in tables 6 and 7. Because Anderson's ore solution (model 1, table 4) can account for sufficient transport of lead and zinc, it was chosen as a guide in constructing the model sedimentary basin brine. Furthermore, model 1 is similar to the oxidized ore fluids proposed by Rose (1976) and Sverjensky (1987) for sediment-hosted, copper-rich deposits (for example, red-bed copper deposits).
Calculated chloride and organic ligand speciation for the model sedimentary basin brine is given in table 6 as percent of ligand bound in the indicated species o- complex. In this oxidized and slightly acid solution, the ligands acetate, oxalate, malonate, and succinate are present primarily as free ions, singly protonated species, and complexes of $\mathrm{Na}, \mathrm{Ca}$, and $\mathrm{Mg}$. Although carboxylate complexes of $\mathrm{Pb}, \mathrm{Zn}, \mathrm{Al}$, and $\mathrm{Fe}$ have a greater thermodynamic stability than carboxylate complexes of $\mathrm{Na}, \mathrm{Mg}$, and $\mathrm{Ca}$, the free ion activities of the former group of metals are too low to allow significant competition with the weakly complsxing, but more abundant, ions of $\mathrm{Na}, \mathrm{Mg}$, and $\mathrm{Ca}$. Catechol, which contains one carboxyl group and a phenolic group, forms very stable metal-organic complexes. At the $\mathrm{pH}$ of the model brine, however, the proton is the domirant cation competitor, and almost 100 percent of the catechol ligand is in the form of the doubly protonated species. Because of the low activity of ionized catechol, only small anounts of metal-catechol complexes are formed. 
Table 5. Speciation of metal-organic complexes in sedimentary basin brines

\begin{tabular}{ll}
\hline \multicolumn{2}{c}{ MODELPARAMETTRS AND CONSTRAINTS } \\
\hline $\begin{array}{l}\text { Galena saturation } \\
\text { Sphalerite saturation }\end{array}$ & $\begin{array}{l}\text { Calcite saturation } \\
\text { Quartz saturation } \\
\text { Potassium feldspar saturation }\end{array}$ \\
\hline INORGANICLIGANDS & \multicolumn{1}{c}{ ORGANIC LGANDS } \\
\hline Chloride 2.5-3.0 molal & Acetate $0.1-0.15$ molal \\
Carbonate & Oxalate 0.005 molal \\
Sulfate & Malonate 0.025 molal \\
Sulfide & Succinate 0.0005 molal \\
Hydroxide & Catechol 0.01 molal \\
\hline
\end{tabular}

Calculated metal speciation for the model brine is given in table 7 as percent of metal bound in the indicated species. Although presented differently, the results in this table for lead and zinc are similar to the results for the model of Anderson (1975) given in table 4; more than 90 percent of the lead and zinc is in chloride complexes, and only 1-3 percent of these metals is bound in carboxylate complexes. Sodium is present primarily as the free ion (75 percent), the chloride complex accounts for 23 percent, and only 2 percent is bound in carboxylate complexes. Calcium and magnesium are also present primarily as free ions or in chloride complexes, but approximately 10 percent of each of these metals is present as an acetate complex, and

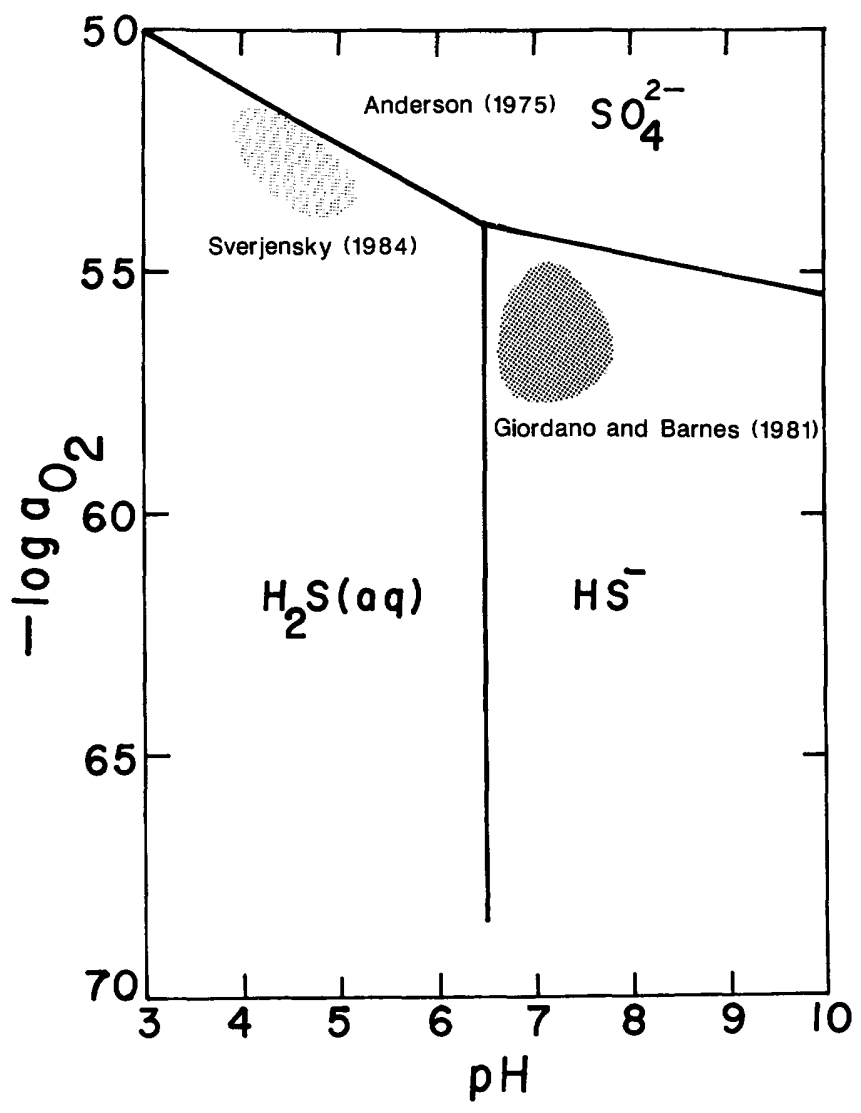

Figure 2. Oxidation state and $\mathrm{pH}$ of model Mississippi Valley-type ore fluids at $100{ }^{\circ} \mathrm{C}$. approximately 4 percent is bound in other carboxylate complexes. Iron is present primarily as the free ion (22 percent), in chloride complexes (46.5 percent), and hydroxide complexes (18 percent). Similar to calcium and magnesium, about 10 percent of the iron is ir acetate complexes and about 4 percent is bound in other carboxylate species. Of all the metals considered in this model, aluminum is the only one that is present in solution predominantly as organic complexes (53 percent). Of the total dissolved aluminum, 25 percent and 47 percent are accounted for by complexes of acetate and hydrolyzed aluminum species, respectively. Note that 10 percent of the aluminum is bound in catechol complexes. Aluminum forms very stable catechol complexes and apparently competes moderately well with protons at near ne"tral $\mathrm{pH}$.

\section{CONCLUSIONS}

The calculated speciations presented in takles 4,6 , and 7 should be considered with caution. More reliable estimates of speciation can be made when additional hightemperature thermodynamic data for metal-organic complexes and additional information regarding pertinent organic ligands and their concentrations in basinal waters are available. Nevertheless, from the results presented in these tables, some important inferences can be mad' regarding metal transport by organic complexes in sedimentary basin brines and related ore fluids. The results presented in table 4 clearly show that in the model ore fluids proposed by Giordano and Barnes (1981) and Sverjensky' (1984) significant amounts of zinc and lead cannot be mobilized as organic complexes involving the ligands acetate, oxalate, malonate, succinate, and catechol; however, other zinc- and lead-organic complexes (organic sulfur complexes) may be important in ore fluids having such model chemistries (Giordano, 1985; Gize and Barnes, 1989). It is alsc possible that these model fluids better describe spent MVT ore solutions at or close to the site of deposition rather than fluids transporting metals to the site of depositior.

In the alternative oxidized ore fluid proposed by Anderson (1975) (model 1, table 4) and the similar brine model described in tables 6 and 7, significant qua ntities of dissolved metal can be accounted for by complexes of the ligands acetate, oxalate, malonate, succinate, and catechol. Both models are similar in oxidation state, $\mathrm{pH}$, temperature and major ion chemistry. Total reduced sulfur is low (about $10^{-9}$ molal), $\mathrm{pH}$ slightly acid (about 5.5), and total chloride to organic ligand ratios high $(\mathrm{C} 1 / \mathrm{Ac}=20, \mathrm{C} 1 / \mathrm{Ox}=600$, $\mathrm{C} 1 / \mathrm{Mal}=120, \mathrm{C} 1 / \mathrm{Suc}=6,000$, and $\mathrm{C} 1 / \mathrm{Cat}=300$ ). In terms of percent of metal bound in metal-organic complexes, the order of importance for the five organic ligands is acetate, malonate, oxalate, succinate, and catechol. In the model brine solution, 53 percent of the aluminum is mobilized in the form of metal-organic complexes. Metrl-organic 
Table 6. Calculated ligand speciation in model sedimentary basin brine having composition similar to ore fluid proposed by Anderson $(1975)^{1}$

[NC indicates not calculated]

\begin{tabular}{|c|c|c|c|c|c|c|c|c|c|c|c|}
\hline \multirow[b]{2}{*}{ Ligand } & \multirow{2}{*}{$\begin{array}{c}\text { Total } \\
\text { molality }\end{array}$} & \multicolumn{10}{|c|}{ Percent ligand bound in indicated species } \\
\hline & & $\mathrm{L}$ & $\mathrm{HL}$ & $\mathrm{H}_{2} \mathrm{~L}$ & $\mathrm{Na}$ & $\mathrm{Ca}$ & $\mathrm{Mg}$ & $\mathrm{Pb}$ & $\mathrm{Zn}$ & $\mathrm{Fe}$ & $\mathrm{Al}$ \\
\hline Chlorit & .2 .85 & 76.27 & $\mathrm{NC}$ & $\mathrm{NC}$ & 14.73 & 5.00 & 4.00 & $<0.01$ & $<0.01$ & $<0.01$ & NC \\
\hline Acetate & .0 .15 & 36.84 & 5.88 & $\mathrm{NC}$ & 20.71 & 29.22 & 7.19 & $<0.01$ & $<0.01$ & $<0.14$ & $<0.01$ \\
\hline Oxalate & .0 .005 & 11.76 & 0.12 & $<0.01$ & $\mathrm{NC}$ & 59.29 & 30.64 & 0.02 & 0.17 & 0.19 & $<0.01$ \\
\hline Malon & .0 .025 & 21.89 & 6.07 & $<0.01$ & 31.95 & 24.45 & 15.46 & $<0.01$ & 0.02 & 0.16 & $\mathrm{NC}$ \\
\hline Succin & .0 .0005 & 37.92 & 9.92 & 0.27 & 23.65 & 23.11 & 5.13 & $<0.01$ & $<0.01$ & $<001$ & $\mathrm{NC}$ \\
\hline Catech & .0 .01 & $<0.01$ & 0.02 & 99.98 & NC & $<0.01$ & $<0.01$ & $<0.01$ & $<0.01$ & $<0.01$ & $<0.01$ \\
\hline
\end{tabular}

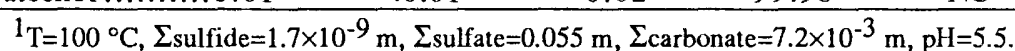

Table 7. Calculated metal speciation in model sedimentary basin brine with composition similar to ore fluid proposed by Anderson (1975) [Model parameters: $\mathrm{T}=100^{\circ} \mathrm{C}, \Sigma$ sulfide $=1.7 \times 10^{-9}, \Sigma$ sulfate $=0.055 \mathrm{~m}, \mathrm{pH}=5.5, \Sigma$ carbonate $=7.2 \times 10^{-3} \mathrm{~m}, \Sigma$ chloride $=2.85 \mathrm{~m}, \Sigma$ acetate $=0.15 \mathrm{~m}, \Sigma$ oxalate $=0.005 \mathrm{~m}$,

$\Sigma$ sussinate $=0.0005 \mathrm{~m}, \Sigma$ malonate $=0.025 \mathrm{~m}, \Sigma$ catechol $=0.01 \mathrm{~m} . \quad \mathrm{NC}$ indicates not calculated]

\begin{tabular}{|c|c|c|c|c|c|c|c|c|}
\hline \multirow[b]{2}{*}{$\begin{array}{l}\text { Total } \\
(\mathrm{ppm})\end{array}$} & \multirow[b]{2}{*}{$\begin{array}{c}\text { Free } \\
\text { ion }\end{array}$} & \multicolumn{7}{|c|}{ Percent metal bound in indicated species complex } \\
\hline & & Chloride & Hydroxide & Acetate & Oxalate & Malonate & Sussinate & Catechol \\
\hline $\mathrm{Na} \ldots \ldots \ldots \ldots 4.84 \times 10^{4}$ & 74.98 & 23.13 & $<0.01$ & 1.50 & $\mathrm{NC}$ & 0.38 & 0.01 & $\mathrm{NC}$ \\
\hline $\mathrm{Ca} \ldots \ldots \ldots \ldots 1.87 \times 10^{4}$ & 72.31 & 16.17 & $<0.01$ & 9.52 & 0.62 & 1.35 & 0.02 & $<0.01$ \\
\hline $\mathrm{Mg} \ldots \ldots \ldots \ldots .2 .24 \times 10^{3}$ & 50.02 & 32.28 & $<0.01$ & 11.72 & 1.69 & 4.26 & 0.03 & $<0.01$ \\
\hline $\mathrm{Pb} \ldots \ldots \ldots \ldots . .2 .79 \times 10^{1}$ & 0.17 & 96.52 & 0.82 & 2.32 & 0.08 & 0.08 & $<0.01$ & 0.01 \\
\hline $\mathrm{Zn} \ldots \ldots \ldots \ldots 1.93 \times 10^{2}$ & 0.27 & 98.38 & 0.55 & 0.56 & 0.23 & $<0.01$ & $<0.01$ & $<0.01$ \\
\hline Fe........... $8.57 \times 10^{1}$ & 22.22 & 46.44 & 18.07 & 9.92 & 0.62 & 2.73 & $<0.01$ & $<0.01$ \\
\hline $\mathrm{A} 1 \ldots \ldots \ldots \ldots .7 .88 \times 10^{-4}$ & 0.06 & $\mathrm{NC}$ & 46.07 & $25.3^{\circ}$ & 17.77 & NC & $\mathrm{NC}$ & 9.90 \\
\hline
\end{tabular}


complexes account for 17 percent, 13 percent, and 11 percent of the magnesium, iron, and calcium, respectively, in solution but only 2.5 percent of the lead, 1.5 percent of the sodium, and 0.8 percent of the zinc. The bulk of the lead and zinc in solution ( $>96$ percent) is solubilized in the form of chloride complexes. These results are in agreement with results of Lundegard and Kharaka (1990), which show that metal-organic complexes are not the dominant form of lead and zinc in typical sedimentary basin brines, but that iron, calcium, and possibly aluminum do form important metalorganic complexes in these waters.

If the oxidized brine model (tables 6 and 7) is modified by increasing each of the organic ligand concentrations by a factor of two or three, a significant shift in favor of organic complexes would be observed. Unpublished data of Giordano and Drummond show for zinc that acetate complexing is dominant relative to chloride complexing in solutions having [chloride ion]/[acetate ion] ratios of less than about 10 at temperatures from 25 to $300{ }^{\circ} \mathrm{C}$. Evidence presented by Lundegard and Kharaka (1990) from brine analyses and theoretical models (which simulate the generation and destruction of organic acids in basinal waters) suggests that concentrations two to three times those given in table 2 are not unreasonable for primary organic acid concentrations. Here, primary concentration is defined as the concentration that exists before significant destruction of the organic acid takes place (Lundegard and Kharaka, 1990). Basinal fluids having such high ligand concentrations (low chloride/organic ligand ratios) are rare but may exist as pore water in metal-rich black shales or petroleum source rocks (Lundegard and Kharaka, 1990). Extraction of metals into these organic-rich pore waters and subsequent expulsion of the metal-rich fluids into more porous rocks during the evolution of sedimentary basins may be the initial stage in the generation of metal-rich basinal brines and related ore fluids.

As mentioned above, the oxidized brine model (tables 6 and 7) is similar in chemistry to the MVT ore solution model of Anderson (1975) and to the brines recommended by Rose (1976) and Sverjensky (1987) as possible ore fluids for red-bed-related copper deposits in shale. Similar brines can now be linked to deposits that have a strong syngenetic character. For example, there is a sufficient body of evidence to infer that most of the lead, zinc, and copper in the highest grade zones of the Kupferschiefer was introduced during late diagenesis by oxidized metal-rich brines at temperatures near $100{ }^{\circ} \mathrm{C}$ (Jowett, 1986; Jowett and others, 1987; Vaughan and others, 1989). And recently, Coveney and others (1987) and Coveney and Glascock (1989) proposed a genetic link between the mineralization of certain Pennsylvanian black shales of the U.S. Midcontinent and basinal brines, possibly MVT ore fluids. This geologic evidence linking basinal brines to syngenetic metal-rich shales and the well-known relationship between basinal brines and classic red-bed copper deposits provide sufficient grounds for the construction of preliminary geochemical models of epigenetic processes related to metalrich black shale deposits.

The basinal brine model presented in this paper (tables 6 and 7) shows that metal-organic complexes may be important in transporting lead, zinc, and other metals in warm, oxidized ore fluids similar to those pronosed by Sverjensky (1987) for red-bed-related copper-rich shales. It is hoped that these results will encourage investigatiors to incorporate metal-organic complexing (including complexes of $\mathrm{Cu}, \mathrm{Ni}, \mathrm{V}, \mathrm{Mo}$, and platinum-group metals) into genetic models for shale-hosted deposits. Although the ore solution models described in this study are based on a less than ideal thermodynamic data base, the principal deficiency is clearly the lack of well-constrained geochemical parameters for Mississippi Valley-type oreforming systems. Efforts to produce reliable ore transport and deposition models for sediment-hosted deposits must focus on the problems of well-constrained geochemical parameters and the procurement of comprehensive and reliable thermodynamic data.

\section{REFERENCES CITED}

Amstutz, G.C., and Bernard, A.J., 1976, Ores in sediments: New York, Springer-Verlag, $350 \mathrm{p}$.

Anderson, G.M., 1975, Precipitation of Mississippi Valley-type ores: Economic Geology, v. 70, p. 937-942.

Barnes, H.L., 1979, Solubilities of ore minerals, in Barnes, H.L., ed., Geochemistry of hydrothermal ore deposits: New York, Wiley-Interscience, p. 405-461.

Bjorlykke, A., and Sangster, D.F., 1981, An overview of sandstone lead deposits and their relation to red-bed copper and carbonate-hosted lead-zinc deposits, in Skinner, B.J., ed., Seventy-fifth anniversary volume: Economic Geology, p. 179-213.

Coveney, R.M., and Glascock, M.D., 1989, A review of the origins of metal-rich Pennsylvanian black shales, cent־al U.S.A., with an inferrred role for basinal brines: Ap chemistry, v. 2, p. 543-561.

Coveney, R.M., Leventhal, J.S., Glascock, M.D., and J'Tatch, J.R., 1987, Origins of metals and organic matter in the Mecca Quarry shale member and stratigraphically equivalent beds across the Midwest: Economic Geology, v. 82, p. 915-933.

Drummond, S.E., and Palmer, D.A., 1986, Thermal decarboxylation of acetate-Part II, Boundary conditions for the role of acetate in the primary migration of natural g?s and the transportation of metals in hydrothermal systems: Geochimica et Cosmochimica Acta, v. 50, p. 825-833.

Drummond, S.E., Palmer, D.A., Wesolowski, D.J., and Giordano, T.H., 1989, Hydrothermal transportation of metals via acetate complexes: International Geological Con ress, 28th, Abstracts, v. 1, p. 420. 
Ellis, A.J., 1963, The ionization of acetic, propionic, n-butyric, and benzoic acid in water, from conductance measurement up to $225^{\circ}$ : Journal of the Chemical Society, v. 59, p. 2299-2310.

Fisher, J.B., 1987, Distribution and occurrence of aliphatic acid anions in deep surface waters: Geochimica et Cosmochimica Acta, v. 51, p. 2459-2468.

Fisher, J.B., and Boles, J.R., 1990, Water-rock interactions in Tertiary sandstones, San Joaquin basin, California, U.S.A.Diagenetic controls on water composition: Chemical Geology, v. 82, p. 83-101.

Fisher, J.R., and Barnes, H.L., 1972, The ion-product constant of water to $350^{\circ}$ : Journal of Physical Chemistry, v. 76, p. 90-99.

Giordano, T.H., 1985, A preliminary evaluation of organic ligands and metal-organic complexing in Mississippi Valley-type ore solutions: Economic Geology, v. 80, p. 96-106. 1989 , Anglesite $\left(\mathrm{PbSO}_{4}\right)$ solubility in acetate solutionsThe determination of stability constants for lead acetate complexes to $85^{\circ} \mathrm{C}$ : Geochimica et Cosmochimica Acta, v. 53 , p. $359-366$.

Giordano, T.H., and Barnes, H.L., 1981, Lead transport in Mississippi Valley-type ore solutions: Economic Geology, v. 76, p. 2200-2211.

Gize, A.P., and Barnes, H.L., 1989, Organic processes in Mississippi Valley-type ore genesis: International Geological Congress, 28th, Abstracts, v. 1, p. 557-558.

Gustafson, L.B., and Williams, N., 1981, Sediment-hosted stratiform deposits of copper, lead, and zinc, in Skinner, B.J., ed., Seventy-fifth anniversary volume: Economic Geology, p. 139-178.

Hanor, J.S., and Workman, A.L., 1986, Distribution of dissolved volatile fatty acids in some Louisiana oil field brines: Applied Geochemistry, v. 1, p. 37-46.

Hennet, R.J.C., Crerar, D.A., and Schwartz, J., 1988, Organic complexes in hydrothermal systems: Economic Geology, v. 83 , p. $742-764$.

Jowett, E.C., 1986, Genesis of Kupferschiefer Cu-Ag deposits by convective flow of Rotliegendes brines during Triassic rifting: Economic Geology, v. 81, p. 1823-1837.

Jowett, E.C., Rydzewski, A., and Jowett, R.J., 1987, The Kupferschiefer $\mathrm{Cu}-\mathrm{Ag}$ ore deposits in Poland-A re-appraisal of the evidence of their origin and presentation of a new genetic model: Canadian Journal of Earth Science, v. 24, p. 2016-3037.

Kharaka, Y.K., Carothers W.W., and Rosenbauer, R.J., 1983, Thermal decarboxylation of acetic acid-Implications for origin of natural gas: Geochimica et Cosmochimica Acta, v. 47 , p. $397-422$.

Kharaka, Y.K., Hall, R.W., and Carothers, W.W., 1985, Waterrock interactions in sedimentary basins, in Relationship of organic matter and mineral diagenesis: Society of Economic Paleontologists and Mineralogists Short Course 17, p. 79-176.

Kharaka, Y.K., Maest, A.S., Carothers, W.W., Law, L.M., Lamothe, P.J., and Fries, T.L., 1987, Geochemistry of metal-rich brines from central Mississippi Salt Dome basin, U.S.A.: Applied Geochemistry, v. 2, p. 543-561.
Lown, D.A., Thirsk, H.R., and Wyane-Jones, L., 1970, Temperature and pressure dependence of the volume of ionization of acetic acid in water from 25 to $22 z^{\circ} \mathrm{C}$ and 1 to 3000 bars: Transactions of the Faraday Society v. 66, p. $51-73$.

Lundegard, P.D. and Kharaka, Y.K., 1990, Geochemistry of organic acids in subsurface waters, in Melchiar, D.C., and Bassett, R.L., eds., Chemical modeling of aqueors systems II: American Chemical Society Symposium Series 416, p. $170-189$.

MacGowan, D.B., and Surdam R.C., 1988, Difunctional carboxylic acid anions in oilfield waters: Organic Geo-hemistry, v. 12 , p. $245-259$.

Martell, A.E., and Smith, R.M., 1977, Critical stability constants, v. 3-Other organic ligands: New York, Plen'm Press, $495 \mathrm{p}$.

1982, Critical stability constants, v. 5-First si’nplement: New York, Plenum Press, 604 p.

Maynard, J.B., 1983, Geochemistry of sedimentary ore deposits: New York, Springer-Verlag, 305 p.

Mesmer, R.E., Patterson, C.S., Busey, R.H., and Holmes, H.F., 1989, Ionization of acetic acid in $\mathrm{NaCl}(\mathrm{aq})$ media- $\mathrm{A}$ potentiometric study to $573 \mathrm{~K}$ and 130 bar: Journal of Physical Chemistry, v. 93, p. 7483-7490.

Nash, J.T., Granger, H.C., and Adams, S.S., 1981, Geology and concepts of genesis of important types of uranium deposits, in Skinner, B.J., ed., Seventy-fifth anniversary volume: Economic Geology, p. 63-116.

Noyes, A.A., 1907, The electrical conductivity of aqueous solutions: Carnegie Institution of Washington Fıblication $63,352 \mathrm{p}$.

Oscarson, J.L., Gillespie, S.E., Christensen, J.J., Izatt, R.M., and Brown, P.R., 1988, Thermodynamic quantities for the interaction of $\mathrm{H}^{+}$and $\mathrm{Na}^{+}$with $\mathrm{C}_{2} \mathrm{H}_{3} \mathrm{O}_{2}{ }^{-}$and $\mathrm{Cl}^{-}$in aqueous solution from 275 to $320^{\circ} \mathrm{C}$ : Journal of Solution Chemistry, v. 17, p. $865-885$.

Palmer, D.A., and Drummond, S.E., 1988, Potentiometric determination of the molal formation constants of ferrous acetate complexes in aqueous solutions to high temperatures: Journal of Physical Chemistry, v. 92, p. 67956800.

Rose, A.W., 1976, The effect of aqueous chloride complexes in the origin of red-bed copper and related deposits: Economic Geology, v. 71, p. 1036-1048.

Stumm, W., and Morgan, J.J., 1981, Aquatic chemistry (2nd ed.): New York, John Wiley and Sons, $780 \mathrm{p}$.

Surdam, R.C., Boese, S.W., and Crossey, L.J., 1984, The chemistry of secondary porosity, in Clastic ciagenesis: American Association Petroleum Geology Memoir 37, p. 127-151.

Sverjensky, D.A., 1984, Oilfield brines as ore-forming solutions: Economic Geology, v. 79, p. 23-37.

1986, Genesis of Mississippi Valley-type lead-zinc deposits: Annual Review of Earth and Planetar.' Science, v. 14, p. 177-199.

1987, The role of migrating oil field brines in the formation of sediment-hosted $\mathrm{Cu}$-rich deposits: Economic Geology, v. 82, p. 1130-1141. 
Thurman, E.M., 1985, Organic geochemistry of natural waters: Boston, Martinus Nijhoff/Dr. W. Junk Pub., 497 p.

Tissot, B.P., and Welte, D.H., 1984, Petroleum formation and occurrence: New York, Springer-Verlag, 699 p.

Tourtelot, H.A., 1979, Black shale-Its deposition and diagenesis: Clays and Clay Minerals, v. 27, p. 313-321.
Vaughan, D.J., Sweeney, M., Diedel, G.F.R., and Haranczyk, C., 1989, The Kupferschiefer-An overview with an appraisal of different types of mineralization: Economic Geology, v. 84, p. 1003-1027.

Wolf, K.H., 1976, Handbook of strata-bound and stratiform ore deposits, v. 6, $\mathrm{Cu}, \mathrm{Zn}, \mathrm{Pb}$, and $\mathrm{Ag}$ deposits: Nevv York, Elsevier, 585 p. 


\title{
When is a Metalliferous Black Shale Not a Black Shale?
}

\author{
By Holly L.O. Huyck ${ }^{1}$
}

\begin{abstract}
Black shales are linked to cycling of carbon, nitrogen, phosphorous, sulfur, oxygen, and heavy metals such as iron, molybdenum, vanadium, and uranium. As a result, they are potentially both mineral and energy resources, and environmental hazards (for example, uranium-rich shales used for roofing in Scandanavia). The importance of such shales prompted the formation of the International Geological Correlation Program (IGCP) Project 254, Metalliferous Black Shales and Related Ore Deposits, in 1987. Yet, based upon discussion at workshops and symposia of ICCP 254, definitions of shale, black shale, and metalliferous black shale either elude us or require revision. The proposed definition for a "black shale" is "a dark-colored (gray or black), fine-grained (silt sized or finer), laminated sedimentary rock that generally is argillaceous and contains appreciable carbon (>0.5 wt. percent)." This is an inclusive definition, and the term should be used with various modifiers that characterize the specific black shale. The traditional definition of metalliferous black shale, based on the classic study of Vine and Tourtelot (1970), requires revision in order to encompass more elements and to account for improved analytical techniques. The proposed definition of a "metalliferous black shale" is "a black shale that is enriched in any given metal by a factor of $2 X$ (except for beryllium, cobalt, molybdenum, and uranium, for which $1 \mathrm{X}$ is sufficient) relative to the U.S. Geological Survey Standard SDO-1."

Characteristics that should be included in the basic description of a black shale include location, stratigraphic position, scale of variation, regional distribution, thickness, sedimentary facies, paleontology, depositional environment, petrography, texture, fabric, color, mineralogy, weight percent organic carbon, weight percent carbonate carbon, weight percent sulfide sulfur, degree of pyritization (DOP), and type and maturity of organic material. Without describing these characteristics, we risk comparing the sedimentary equivalents of apples and oranges in our geochemical, isotopic, and other studies.
\end{abstract}

Ohio 45221.

\section{INTRODUCTION}

In 1986, the editors of "Biogeochemistry of black shales" (Degens and others, 1986, p. IX) wrote:

"A great variety of rocks are designated as black shales. Their composition[s] and origins difer greatly. For instance, they can be bituminous, phosphatic, carbonate-free or -rich, high or low in trace metals, sulfidic to a point of even being considere ore, and sometimes surprisingly low in carbon when compared to the average shale. With respect to [the] environment of deposition, a black shale can be of freshwate", brackish, marine or hypersaline origin, in other words, tlack shales can virtually be found in all aquatic habitats. They may contain abundant macro- and microfossils, or may be fossil-free. Black shales may be laid down in the shallow epicontinental sea, along continental margins, or in deep oceans and lakes. They can be formed in situ, or be allochthonous in nature. Their organic matter can be mature or immature***'Why do we group such a diverse group of sediments together which obviously only share one property, namely that of being black?'

The answer is: all black shales are linked directly or indirectly to high organic activity and the cycling of biogeochemical elements, most notably carbon, nitrogen, phosphorus, sulfur, oxygen plus heavy metcls such as iron, molybdenum, vanadium, and uranium."

Because the term black shale includes such a wide variety of sediments and sedimentary rocks it has been difficult to find a definition that is inclusive yet meaningful. The definitions proposed in this paper are based on verbal and written discussions of definitions previously' presented at various times by the author to members of the U.S. Working Group of the International Geological Correlation Program (IGCP) Project 254.

The purpose and structure of this paper are twofold. First, previous and proposed definitions of black shale and metalliferous black shale are briefly reviewed. Serond, a list of the minimum number of characterizations of a shale needed in order to compare it to other shales is presented. A very inclusive definition of black shale is preferred, with a 
Table 1. Mudrocks as classified by Spcars (1980)

\begin{tabular}{|c|c|}
\hline $\begin{array}{l}\text { Percent } \\
\text { quartz }\end{array}$ & Nonfissile \\
\hline $\begin{array}{l}<40 \\
30-40 \\
20-30 \\
10-20 \\
<10\end{array}$ & $\begin{array}{l}\text { Flaggy siltstone.........Massive siltstone. } \\
\text { Very coarse shale....... Very coarse mudstone. } \\
\text { Coarse shale...............Coarse mudstone. } \\
\text { Fine shale................Fine mudstone. } \\
\text { Very fine shale.......... Very fine mudstone. }\end{array}$ \\
\hline
\end{tabular}

Degens and others (1986) have stated, the term black shale covers a multitude of variations, providing the potential for comparing the sedimentary equivalents of apples, oranges, and rutabagas.

\section{DEFINITION OF SHALE}

Based upon historical usage, "shale" has "the meaning of the 'general class of fine-grained rocks"' (Tourtelot, 1960 , p. 342). As Spears (1980) noted, a more appropriate term may be either "mudrock" or "mudstone" because neither implies any laminations or fissility. The author prefers to follow tradition and to use the term shale.

Spears $(1980$, p. 127) defined a shale as "a fissile or laminated [fine-grained] rock." He classified the "mudrocks" in his study by presence or lack of fissility and by percentage of quartz (table 1). In the Coal Measures that he has studied, quartz is the major clastic (silt sized) component; feldspar is negligible, and total [carbonates + sulfides + organic carbon] are less than 10 percent. Percent quartz may correlate with the silt-sized fraction in Spears' rocks but not necessarily in rocks containing significant quantities of feldspar.

Potter and others $(1980$, p. 13) defined shale as a "fine-grained***sediment*** that contain[s] 50 percent or more of terrigenous, generally argillaceous, clastic components less than $0.062 \mathrm{~mm}$ " in equivalent spherical diameter. This definition is useful because it is easy to understand. Unlike the definition of Spears, it includes both fissile and nonfissile rocks. Their classification of shale is based on laminations, grain size, and degree of induration (table 2). Admittedly, grain-size determinations of indurated sedimentary rocks are difficult and qualitative. G. Desborough (U.S. Geological Survey, written commun., 1989) noted that many clay minerals and feldspar are commonly authigenic, and thus grains may be neither terrigenous nor clastic. If the $0.062-\mathrm{mm}$ size cutoff is used for all rock constituents and "terrigenous" is replaced with "nonchemical," perhaps such objections can be averted.

In light of the above discussion, the following definition for shale is proposed. A shale is a fine-grained, nonchemical sediment that contains 50 percent or more particles less than 0.062-mm equivalent spherical diameter in size.

\section{DEFINITION OF BLACK SHALE}

A similar problem occurs for defining black shale. For example, Arthur (1979, as quoted in Waples, 1983, p. 963) used "black shale" to mean "****relatively organicrich (i.e. $>0.5$ wt. percent $\mathrm{C}_{\text {org}}$ ), dark-colored (dark gray, greenish black, and black) mudstone and marlstone which may or may not be "shale' in the classical sense."

An arbitrary lower limit can be set for weight percent of organic carbon in black shales. Arthur (1979) s'ıgested 0.5 percent, M. Zentilli (Dalhousie University, oral commun., 1989) and M. Graves (Cuesta Research Itd., oral commun., 1989) 0.6 percent, Brumsack (1980, as auoted in Waples, 1983) and M. Lewan (Amoco, oral commun., 1990) 1.0 percent, and Kukal (1988) 1.5-2.0 percent. Analyses of Devonian shales in the Appalachian b 'sin (fig. 1) indicate a break at 1.0 percent organic carbon. Stribrny and Urban (1989) and Urban and Stribrny (1989), in their classification of the "black shale series," separated $>1$ percent and $<1$ percent organic carbon and incluced black shale in the $>1$ percent organic carbon portion (fig. 2). Bates and Jackson (1987) used 5 percent organic carbon for the minimum in black shales; however, the mediar for the "black shale" samples of Vine and Tourtelot (19ii) is 3.2 percent, and samples containing as little as 0.4 percent (Nonesuch Shale) are included.

A strong argument may be made to place the lower limit at 1.0 percent organic carbon. The organi : carbon content of "average shale" has been quoted as 0.65 percent (after Green, 1959, as quoted in Vine and Tourtelot, 1970, table 3, p. 261), 0.8 percent (Potter and others, 15? ?, table 1.8 , p. 51), and 2.1 percent (Degens, 1965, p. 202). The last average, in particular, may reflect a large number of shales sampled from petroleum-bearing basins. Although the minimum amount of organic carbon necessary to produce hydrocarbons is approximately 0.5 percent (Potter and others, 1980), the minimum needed to be an effective hydrocarbon source rock is approximately 2.4 percent (Lewan, 1987).

Problems exist with setting an arbitrary lo'ver limit for organic carbon content. For example, if an arbit-ary limit of 1.0 percent organic carbon is set for an immature shale, what should be the limit for a thermally mature shale? Hydrocarbons may have moved in or out, depencing upon the thermal maturity of the shale. F. Poole (U.S. Geological Survey, oral commun., 1989) pointed out that thermally mature shales may contain only $0.1-0.3$ percen* organic carbon, much less than their original content. Raiswell and Berner (1987) charted a significant loss of organ: carbon (as much as $40-60$ percent) in normal marine shales as vitrinite reflectance increases, and Baker and Claypool (1970) demonstrated the loss of organic carbon during incipient metamorphism. Additionally, a "black" shale may contain less organic matter than a dark-gray shale (R. Schultz, University of Cincinnati, oral commun., 1990). 
Table 2. Classification of shale (more than 50 percent grains less than $0.062 \mathrm{~mm}$ ) according to Potter and others (1980)

\begin{tabular}{|c|c|c|}
\hline $\begin{array}{l}\text { Percentage } \\
\text { clay-size constituents..............0-32 }\end{array}$ & $33-65$ & $66-100$ \\
\hline Field adjective $\ldots \ldots \ldots \ldots \ldots \ldots \ldots \ldots$ Gritty & Loamy & Fat or slick \\
\hline \multicolumn{3}{|c|}{ NONINDURATED } \\
\hline $\begin{array}{l}\text { Beds (greater than } 10 \mathrm{~mm} \text { ).........Bedded silt } \\
\text { Laminae (less than } 10 \mathrm{~mm} \text { )........Laminated silt }\end{array}$ & $\begin{array}{l}\text { Bedded mud } \\
\text { Laminated mud }\end{array}$ & $\begin{array}{l}\text { Bedded claymud } \\
\text { Laminated claymud }\end{array}$ \\
\hline \multicolumn{3}{|c|}{ INDURATI:D } \\
\hline $\begin{array}{l}\text { Beds (greater than } 10 \mathrm{~mm} \text { )..........Bedded siltstone } \\
\text { Laminae (less than } 10 \mathrm{~mm} \text { )........Laminated siltstone }\end{array}$ & $\begin{array}{l}\text { Mudstone } \\
\text { Mudshale }\end{array}$ & $\begin{array}{l}\text { Claystone } \\
\text { Clayshale }\end{array}$ \\
\hline \multicolumn{3}{|c|}{ METAMORPIOSED } \\
\hline \multicolumn{3}{|c|}{ 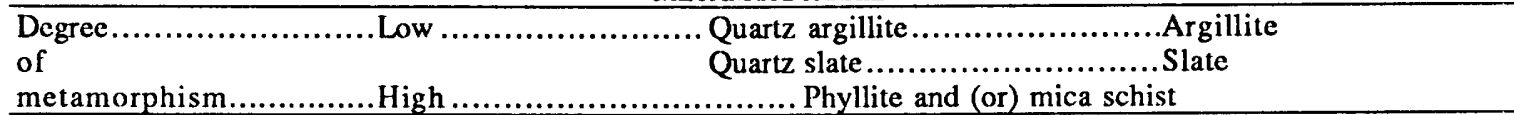 } \\
\hline
\end{tabular}

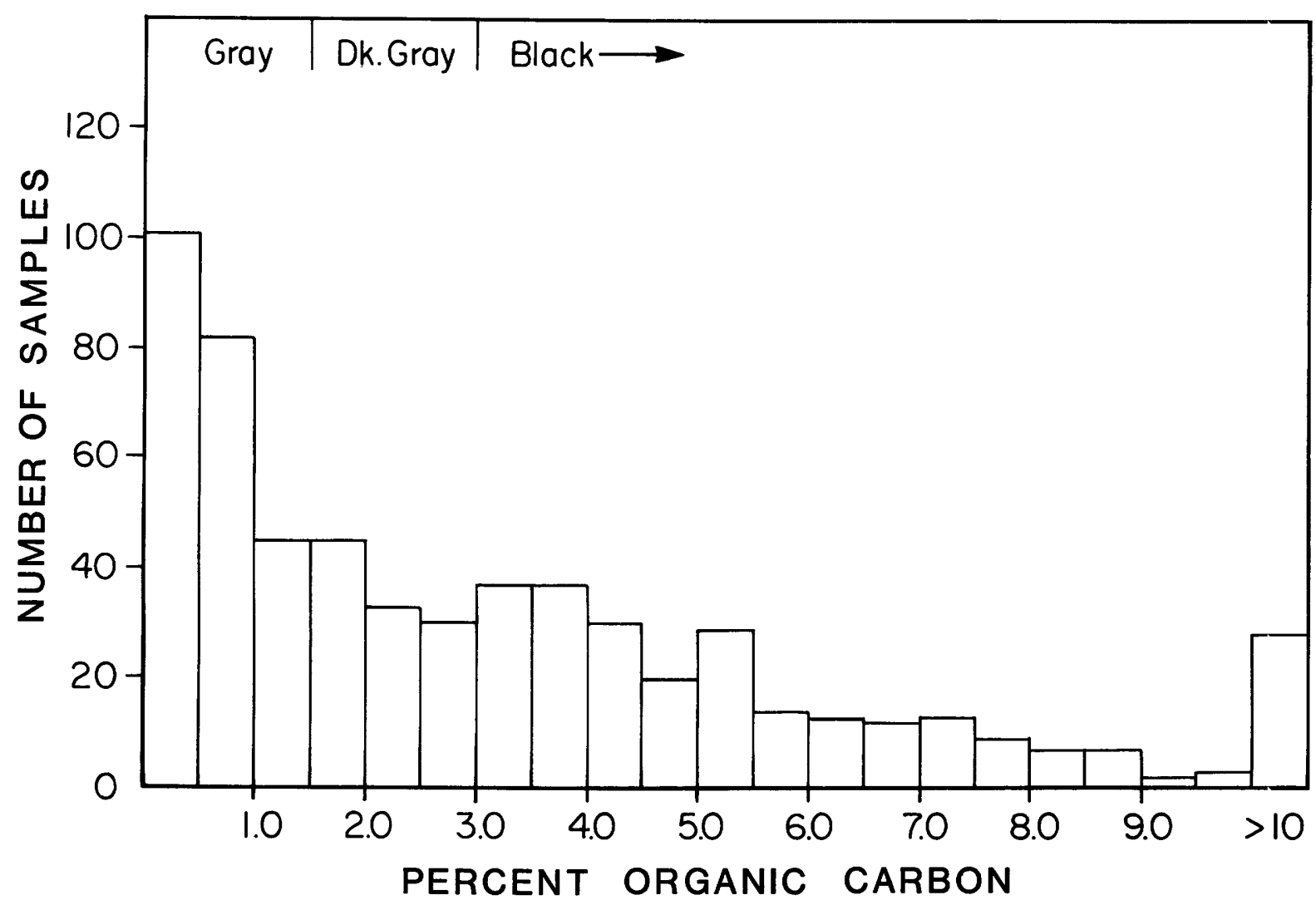

Figure 1. Weight percent organic carbon in Devonian shale samples (577) from the Appalachian Basin. From unpublished data of J.B. Maynard (University of Cincinnati, written commun., 1989).

The use of color as a definitive characteristic is untenable because even with color charts, gray to one person is black to another. Kukal (1988) noted that, although organic carbon content is the major factor influencing color, finely disseminated iron sulfide or manganese oxide minerals may also color the shale. In the Black Sea, recent deposits are deep green and brown (Kukal, 1988). Conversely, when shales are exposed, weathered, or dehydrated, they may turn gray, green or brown (for example, the Flowerpot Shale, host ro:k for the Creta copper shale deposit, Oklahoma).

An arbitrary lower limit of organic carbon content, which varies with thermal maturity, is preferatle. If the IGCP 254 group can find other, less transitory signatures of original organic content, then these could be incorporated. In their absence, a relatively low cutoff is recommended, 


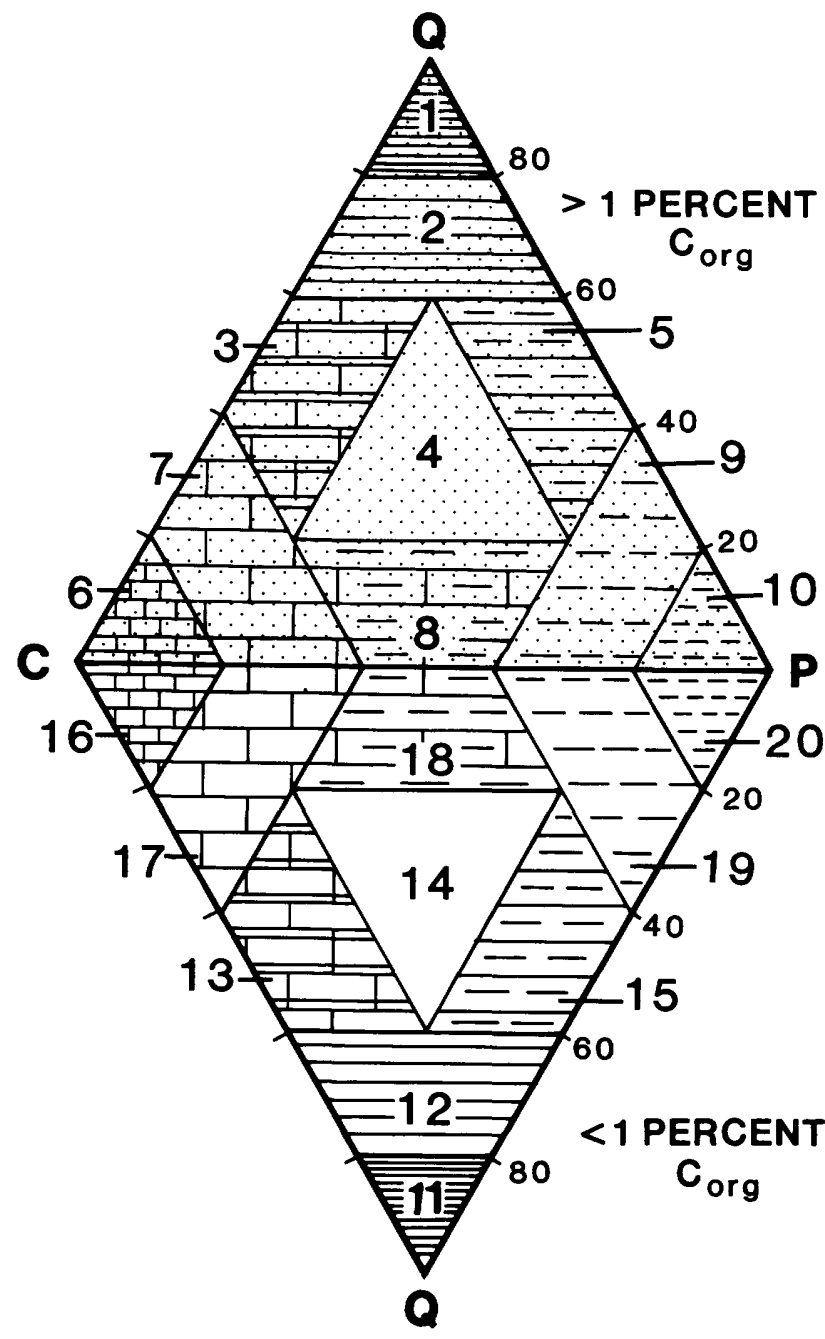

Figure 2. Classification and nomenclature of fine-grained sedimentary rocks associated in the "black shale series" of Stribrny and Urban (1989) and Urban and Stribrny (1989). Apexes are quartz $(Q)$, phyllosilicates $(P)$, and carbonates plus remaining minerals $(C)$. Normative mineral compositions $(Q+P+C=100)$ are plotted in the upper triangle if organic carbon $\left(C_{\text {org }}\right.$ ) is greater than 1 percent and in the lower triangle if it is less than 1 percent. Normative minerals are based on weight percentages of different elements or oxides using chemical analyses of samples. Classification fields: 1 , organic-carbon-rich lydite; 2 , siliceous black shale; 3, carbonatic-siliceous black shale; 4, black shale; 5, argillaceous-siliceous black shale; 6 , organic-carbon-rich carbonate rock; 7 , carbonatic black shale; 8 , carbonaticargillaceous black shale; 9, argillaceous black shale; 10, organic-carbon-rich pelite; 11 , lydite; 12 , siliceous shale; 13, carbonatic-siliceous shale; 14 , shale; 15 , argillaceoussiliceous shale; 16, carbonate rock; 17, carbonatic shale; 18, carbonatic-argillaceous shale; 19, argillaceous shale; 20, pelite.

such as 0.5 or 0.6 percent organic carbon. The resulting definition includes most documented "black shale" samples; other modifiers can be added for characterization (see later discussion.)
Including the term "laminated" in the definition of black shale further delimits the minimum organic carbon content at the time of sediment deposition. Presence of laminations, at least in Phanerozoic shales, requires a lack of significant bioturbation and so indicates conditions too hostile to support a burrowing fauna. Such conditions, whether due to insufficient oxygen in the bottom water, excess salinity, or other factors, promote preservation of organic matter. Although burrows may be present, they are minor enough to limit disruption of the fabric to $\leq 2$ on the ichnofabric scale as defined by Droser and Bottjer (1986).

In light of the above comments, a definition for black shale is proposed, based on discussion among U.S. Working Group IGCP 254 members:

A black shale is a dark-colored (gray or black), fine-grained (silt sized or finer), laminated sedimentary rock that generally is argillaceous and contains appreciable organic carbon ( $>0.5$ weight percent).

This inclusive definition can be used with a variety of modifiers to further specify the rock type being d:scussed. The definition modifies the general definition of st ale used earlier in this paper because shales containing $4 C$ percent organic carbon (for example, within the New Albany Shale) may contain less than 50 percent particles of less than $0.062-\mathrm{mm}$ equivalent spherical diameter.

\section{DEFINITION OF A METALLIFEROUS BLACK SHALE}

The classic definition of metalliferous black shales is that proposed by Vine and Tourtelot (1970, p. 253). "A black shale is defined as metal-rich if any minor element [of 21 chosen] occurs in excess of the 90th percentile as determined from the sum of the percent frequency distribution of elements in the 20 sets of [779] black shale samples." This landmark effort provided a commc nly used definition for subsequent research. Since it wes made, however, analytical techniques have improved significantly. In addition, other elements, such as the rare-earth elements, gold, phosphorous, and sulfur, are now elements of interest. These can be considered minor relative to the quastion of whether the sample set is appropriate; some of the black shales in the study of Vine and Tourtelot do not fit the definition recommended here.

A second approach, suggested by $\mathrm{M}$. Zentilli and $\mathrm{M}$. Graves on the U.S. Working Group 1989 IGCP 254 field trip, is to define a black shale as metalliferous if any metal content exceeds two times the average continertal crust composition. The required multiple exceeding this number can be readjusted. The main question is whether this approach is preferred. The approach has the advantage of not depending on a particular sample set or on analytical techniques at a particular time. Also, the number of elements included is larger than the 21 elements of Vine and Tourtelot. 
Table 3. Abundances of elements (in parts per million) in black shale and metal-rich black shale and in average continental crust

[Elemental values in parts per million]

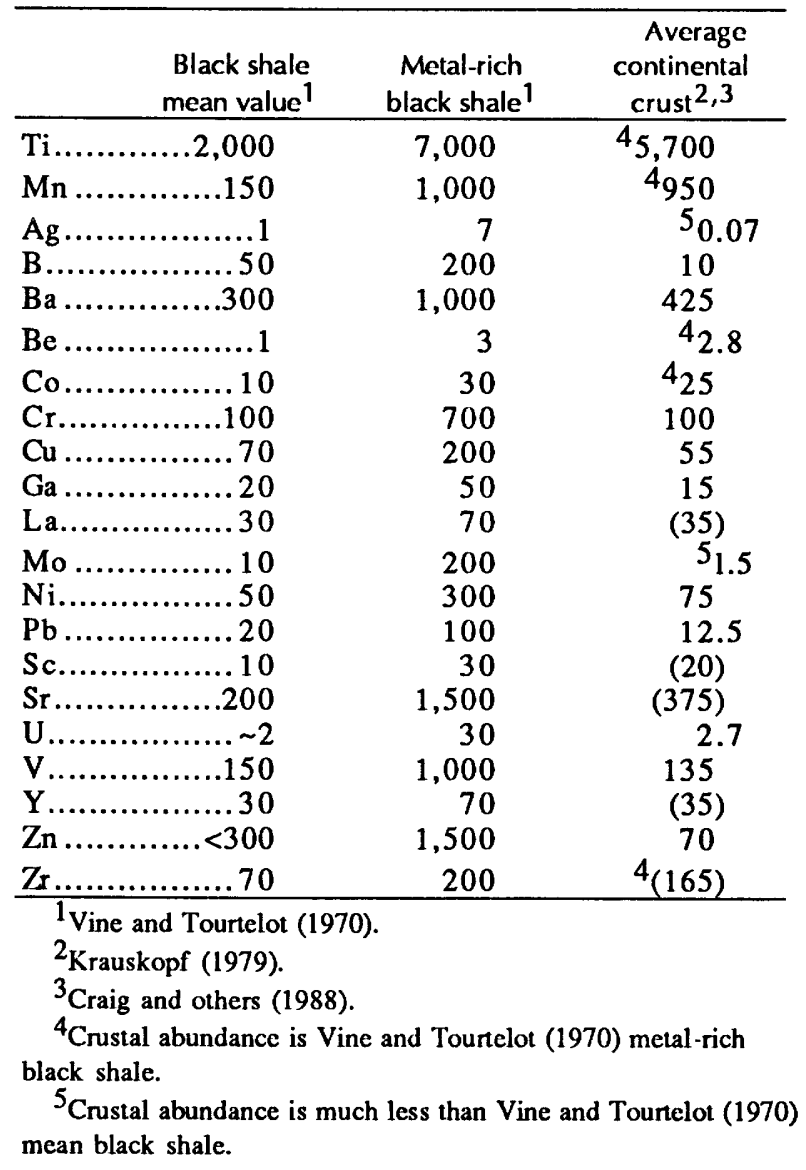

An example of what would be considered a metalliferous black shale in these first two cases is shown in table 3. Note that the mean values are quite similar for the two groups except for $\mathrm{Ti}, \mathrm{Mn}, \mathrm{Be}, \mathrm{Co}, \mathrm{Zr}$ (where crustal mean equals Vine and Tourtelot's "metal-rich," or "metalliferous") and Ag and Mo (where the crustal mean is at least six times less than Vine and Tourtelot's mean). If $2 \mathrm{X}$ of average continental crust is used, the definitions will be similar.

A third approach, suggested by J.S. Leventhal (U.S. Geological Survey, oral commun., 1989), is to base a definition for metalliferous shale on an arbitrary total of various elements. If each component is expressed in parts per million, then a metalliferous shale would contain:

$$
\begin{gathered}
{[(\mathrm{V}+\mathrm{Cr}+\mathrm{Co}+\mathrm{Ni}+\mathrm{Cu}+\mathrm{Zn}+\mathrm{Mo}+\mathrm{Ag}+\mathrm{Cd}+\mathrm{Pb}+\mathrm{U})} \\
\quad+(\mathrm{As}+\mathrm{Se}+\mathrm{Sb}+\mathrm{Tl})+(\mathrm{Ba}+\mathrm{Mn}+\mathrm{REE}+\mathrm{Zr}) / 5 \\
\left.\quad+\left(\mathrm{C}_{\text {organic }}+\mathrm{S}+\mathrm{Fe}\right) / 1,000\right]>1,000
\end{gathered}
$$

Again, the specifics of the numbers are not as important as the general format. Such a definition is quite arbitrary, yet is independent of the specific nature of any one data set. It invokes a slightly different philcsophy by focusing on the sum total of a variety of elements, instead of any one, similar to the idea of co-products insteat of main product versus byproduct. It is more restricted than the second approach in that it uses specific elements. Leventhal suggested this as a possible format but is not vedded to the specific numbers. (I would prefer to delete the $\left(\mathrm{C}_{\text {organic }}+\mathrm{S}+\mathrm{Fe}\right)$ term because, although these elements are important for constraining the environment of døosition, they add little information about economic metal content.)

At the 1989 U.S. Working Group meeting of IGCP 254 , an alternative definition was proposed that uses twice the metal content of the North American Shale Composite (NASC), rather than the average continental crust, as a basis for defining metalliferous black shale. Initially, this approach presented several advantages. The NASC has been analyzed by more qưantitative techniques (Gromet and others, 1984; Taylor and McLennan, 1988) than have the samples of Vine and Tourtelot (1970), and it in ludes 28 trace and rare-earth elements. Comparison to NASC is preferable to an average continental crust, which is vaguely defined. Allowing one metal to define a black shale as metalliferous permits seeking significant anomal is rather than looking for a slightly elevated content of several metals. (Note that "metal," if used to mean transition metals and lanthanides, would exclude elements in the first two columns of the periodic table. Thus, $\mathrm{Rb}, \mathrm{Sr}, \mathrm{Ba}$, and $\mathrm{Cs}$ could not be used to define a shale as metallifercus.)

In subsequent efforts to compile analyse for the NASC, I discovered a number of problems with using it as the standard. First, important elements are missing. For example, $\mathrm{Au}, \mathrm{Ag}, \mathrm{Mo}, \mathrm{Pb}$, and $\mathrm{Zn}$ were not analyzed. Because these elements are important to many investigators, the NASC is not a particularly useful standard. Second, the NASC is a composite of 40 samples, not all from North America, and 15 of which are not located at all (Gromet and others, 1984). Third, no significant descriptions of the shales are available, so one has no idea whether even one of the shales is a black shale. Additionally, Gromet and others (1984) noted a significant variability problem in th $?$ NASC. Other published shale composites, the Post-Archean Australian Shale (PAAS), the European Shale (ES), and the Marine Sciences Group Black-Shale Composite (MSG-: BSC) (Gromet and others, 1984; Quinby-Hunt and others, 1989; Taylor and McLennon, 1988), suffer from a similar lack of elements (see table 5). Thus, search for another shale standard commenced.

Following discussions with Richard Grauch, leader of the U.S. Working Group, and with Joel Leventhal, I propose replacing the NASC with the U.S. Geological Survey standard SDO-1. This is the "USGS Devonian Otio Shale" (from Kentucky) that was discussed in the May 1988 
"Friends of Black Shales" newsletter (R.I. Grauch, written commun., 1988) and for which initial analyses were compiled by Belinda Arbogast. There are several advantages to using this standard. This sample is well located, both geographically and stratigraphically. It has been analyzed by approximately 30 laboratories around the world, is chemically well characterized, and has confidence limits for each element (table 4). SDO-1 also qualifies as a black shale under the definition given above. One disadvantage is that one sample is by definition not an "average" shale. (A brief description of SDO-1 characteristics is given later.)

The analyses of SDO-1, shown in table 4, have been published in Geostandards Newsletter (Kane and others, 1990). The varying confidence limits for individual elements-Recommended, Average, and Range-reflect decreasing confidence in reported values. For elements having only reported ranges, a midpoint of the range has been arbitrarily chosen as the value shown in table 5 . Here, SDO-1 values are compared with analyses of the other possible standards mentioned above.

Because many investigators have used the definitions of Vine and Tourtelot (1970), it is important to note whether this new definition will significantly change their classification of "metal-rich black shales." As table 5 shows, SDO-1 is "metal-rich" by the definition of Vine and Tourtelot for four trace elements-Be, Co, Mo, and U. Relative to "metalliferous" concentrations of 19 trace elements (Ti, Mn excluded here) used in the definition of Vine and Tourtelot, 8 are higher using the proposed definition and 11 are lower. $\mathrm{Be}, \mathrm{Co}, \mathrm{Mo}$, and $\mathrm{U}$ are more than two times the "Minimum Enrichment Values" for Vine and Tourtelot's definition of metal-rich shales, and $\mathrm{Ag}, \mathrm{Ba}$, $\mathrm{Cr}, \mathrm{Sr}, \mathrm{V}$, and $\mathrm{Zn}$ are less than half. Changes to lower thresholds are at least in part due to improvements in analytical techniques (such as for silver). Thus, no adjustments are recommended for the new standard for these five elements. The four elements that are high in SDO-1 do provide some cause for concern regarding whether metalliferous black shales should be defined on the basis of enrichment relative to a black shale that is itself metal rich by the older definition. However, defining a black shale as metalliferous if it contains the same amount of $\mathrm{Be}, \mathrm{Co}$, Mo or $\mathrm{U}$ as SDO-1 preserves the Vine and Tourtelot definition as much as possible.

If the SDO-1 standard is substituted for the NASC, then the proposed definition becomes:

A metalliferous black shale is a black shale that is enriched in any given metal by a factor of $2 X$ (except beryllium, cobalt, molybdenum, and uranium, for which $1 X$ is sufficient) relative to the U.S. Geological Survey Standard SDO-1.

I recommend the new definition for metalliferous black shale, with the noted reservations that SDO-1 is not an average black shale and that the definition is somewhat arbitrary. The choice exists for continuing to use Vine and Tourtelot (with good sample statistics but limited elements and analytical precision), using other composite shales (each with limited elements and without organic carbon analyses), or using SDO-1 (with good analytical statistics and a full range of trace elements). Although none of these provides an ideal basis for defining a metalliferous black shale, I prefer to use the well-characterized SD?-1. I suggest that U.S. Working Group members of IGCP 254 review their own analyses to determine whether th 's new definition significantly changes the classification of black shales as metalliferous or not. If the designations do not shift significantly for the 19 elements used in Vine and Tourtelot (1970), then I would have more confidence in using the proposed definition for elements heretofore not used. (The question of which elements are significant, as noted before, has yet to be fully resolved.)

\section{CHARACTERIZATION OF BLACK SHAIE}

Given the proposed definition of a black shale, a vast variety of shales will be included that require further characterization. What is the minimum number of modifiers necessary to characterize a black shale? Table 6 show's a list of modifiers, not in order of importance but rather in order parallel with the Compendium list that Zimmerle and Stribrny (1989) compiled for "carbon-rich pelitic sediments in the Federal Republic of Germany" and whi h J.S. Leventhal (oral commun., 1989) proposed for use in developing a similar compendium in the United States. A few of these topics have been consolidated in this discussion. Location should be as specific as possible for resampling purposes. In addition to stratigraphic position and thickness of the entire unit described, scale of variation should be noted. If one takes samples randomly from a black shale that is several hundred meters thick, the results will be meaningless. Consider the Chainman Shale. which includes a variety of facies and a phosphatic member. Noting the scale of variation is critical (for example, is it all laminated, is there an even or periodic distribution of pyrite, does color change?). Determining facies changes within a particular bed is similarly important for sampling. This may seem obvious, but, in our increasing emphasis on analytical techniques, we must continue to consider the field methods that form the basis for all subsequent work. Regional distribution is obvious for paleogeographic, paleoenvironmental, and facies considerations. Similarly, paleontology is needed; complete absence of fauna or variations in bioturbation are useful indicators of paleoenvironment.

Petrography includes color (not all black stales or organic-rich shales are black); fabric (variations in laminations and ichnofabric may have genetic implications); and grain-size distribution; and visual identification of organic matter (to clarify organic geochemistry). With today's 
Table 4. Summary of USGS SDO-1 characterization study

\begin{tabular}{|c|c|c|c|c|}
\hline $\begin{array}{l}\text { Content or } \\
\text { in sample in d } \\
\text { as received or }\end{array}$ & $\begin{array}{l}\text { No. labs surviving } \\
\text { outlier rejection, used } \\
\text { deriving recommended } \\
\text { or average values }(\mathrm{N})\end{array}$ & Recommended $^{1}$ & Average $^{2}$ & Range $^{3}$ \\
\hline \multicolumn{5}{|c|}{ PERCENT } \\
\hline $\mathrm{SiO}_{2}$ & 26 & $49.28 \pm 0.63$ & & \\
\hline $\mathrm{Al}_{2} \mathrm{O}_{3}$ & 22 & $12.27 \pm 0.23$ & & \\
\hline $\mathrm{Fe}_{2} \mathrm{O}_{3} \mathrm{~T}$ & 24 & $9.34 \pm 0.21$ & & \\
\hline $\begin{array}{l}\mathrm{CaO} \\
\mathrm{MgO} \\
\mathrm{Na}_{2} \mathrm{O}\end{array}$ & $\begin{array}{l}22 \\
22 \\
21\end{array}$ & $\begin{array}{l}1.05 \pm 0.047 \\
1.54 \pm 0.038 \\
0.38 \pm 0.026\end{array}$ & & \\
\hline $\mathrm{K}_{2} \mathrm{O}$ & 21 & $3.35 \pm 0.061$ & & \\
\hline $\mathrm{P}_{2} \mathrm{O}_{5}$ & 19 & $0.110 \pm 0.007$ & & \\
\hline $\mathrm{TiO}_{2}$ & 23 & $0.710 \pm 0.031$ & & \\
\hline $\begin{array}{l}\mathrm{MnO} \\
\mathrm{LOI} \\
\mathrm{S} \\
\mathrm{CO}_{2}\end{array}$ & $\begin{array}{r}19 \\
12 \\
7 \\
8\end{array}$ & $\begin{array}{c}0.0419 \pm 0.005 \\
21.7 \pm 0.90 \\
5.35 \pm 0.44 \\
1.01 \pm 0.21\end{array}$ & & \\
\hline $\mathrm{C}_{\mathrm{TOT}}$ & 12 & $9.95 \pm 0.44$ & & \\
\hline $\mathrm{C}_{\text {org }}$ (measured & ed) & & & $8.98-10.4$ \\
\hline $\mathrm{C}_{\text {org }}$ (calculater & ted) & $9.678 \pm 0.452$ & & \\
\hline $\begin{array}{l}\text { Content } \\
\text { in sample in d } \\
\text { as received or } \\
\end{array}$ & $\begin{array}{l}\text { No. labs surviving } \\
\text { outlier rejection, used } \\
\text { deriving recommended } \\
\text { or average values }(N)\end{array}$ & Recommended $^{1}$ & Average $^{2}$ & Range $^{3}$ \\
\hline \multicolumn{5}{|c|}{ PARTS PER MIILLION } \\
\hline $\mathrm{Ag}$ & 2 & & & $0.092-0.17$ \\
\hline As & 7 & $68.5 \pm 8.5$ & & \\
\hline $\mathrm{Aul}$ & 2 & & & $0.002-0.0035$ \\
\hline B & 5 & & $128 \pm 11$ & \\
\hline $\mathrm{Ba}$ & 17 & $397 \pm 38$ & & \\
\hline $\mathrm{Be}$ & 9 & $3.3 \pm 0.57$ & & \\
\hline $\mathrm{Bi}$ & 2 & & & $2-<10$ \\
\hline $\mathrm{Br}$ & 1 & & & \\
\hline $\mathrm{Cd}$ & 3 & & & $<2-<10$ \\
\hline $\mathrm{Ce}$ & 18 & $79.3 \pm 7.8$ & & \\
\hline $\mathrm{Cl}$ & 1 & & & 116 \\
\hline Co & 23 & $46.8 \pm 6.3$ & & \\
\hline $\mathbf{C r}$ & 24 & & $66.4 \pm 7.6$ & \\
\hline Cs & 6 & & $6.9 \pm 1.2$ & \\
\hline $\mathrm{Cu}$ & 23 & & $60.2 \pm 9.6$ & \\
\hline Dy & 5 & & $5.7 \pm 0.99$ & \\
\hline Er & 3 & & & $2.5-4.7$ \\
\hline $\mathrm{Eu}$ & 7 & & $1.6 \pm 0.22$ & \\
\hline $\mathbf{F}$ & 2 & & & $<0.01-0.07$ \\
\hline $\mathrm{Ga}$ & 9 & $16.8 \pm 1.8$ & & \\
\hline Gd & 4 & & $6.5 \pm 1.2$ & \\
\hline Ge & 1 & & & 1.3 \\
\hline Hf & 6 & & $4.7 \pm 0.75$ & \\
\hline
\end{tabular}

increasing concern about the physical characteristics of shales, especially permeability, fabric and grain-size distribution are especially useful. For example, the Nonesuch Shale is a laminated siltstone that has significantly higher horizontal permeability than one might expect in a "shale." At the Creta deposit, a copper-rich shale in
Oklahoma, sulfide minerals are concentrated along coarser grained laminae within the mudshale (Huyck and Chorey, 1989). Thus, thin section petrography can be useful in studying at least some black shales.

Mineralogy is useful in interpreting source and diagenetic evolution of the shale. Stribrny and Urban (1989) 


\section{Table 4. Continued}

\begin{tabular}{|c|c|c|c|c|}
\hline $\begin{array}{l}\text { Content } \\
\text { in sample } \\
\text { as received }\end{array}$ & $\begin{array}{c}\text { No. labs surviving } \\
\text { outlier rejection, used } \\
\text { in deriving recommended } \\
\text { or average values }(\mathrm{N})\end{array}$ & Recommended $^{1}$ & Average $^{2}$ & Range ${ }^{3}$ \\
\hline $\mathrm{Hg}$ & 4 & & $0.19 \pm 0.08$ & \\
\hline Ho & 2 & & & $1.1-3.3$ \\
\hline In & 1 & & & $<0.2$ \\
\hline $\mathbf{L a}$ & 18 & $38.5 \pm 4.4$ & & \\
\hline $\mathbf{L i}$ & 6 & $28.6 \pm 5.5$ & & \\
\hline Lu & 7 & $0.52 \pm 0.099$ & & \\
\hline Mo & 15 & $134 \pm 21$ & & \\
\hline $\mathrm{Nb}$ & 10 & $11.4 \pm 1.2$ & & \\
\hline Nd & 11 & $36.6 \pm 3.3$ & & \\
\hline $\mathrm{Ni}$ & 25 & $99.5 \pm 9.9$ & & \\
\hline $\mathrm{Pb}$ & 13 & $27.9 \pm 5.2$ & & \\
\hline Pr & 3 & & & $6-13.8$ \\
\hline $\mathbf{R b}$ & 11 & & $126 \pm 3.9$ & \\
\hline $\mathrm{Sb}$ & 3 & & & $4.1-4.8$ \\
\hline Sc & 15 & $13.2 \pm 1.5$ & & \\
\hline $\mathrm{Se}$ & 2 & & & $3-6.8$ \\
\hline $\mathrm{Sm}$ & 7 & $7.7 \pm 0.81$ & & \\
\hline $\mathrm{Sn}$ & 4 & & $2.9 \pm 0.38$ & \\
\hline $\mathrm{Sr}$ & 21 & $75.1 \pm 11.0$ & & \\
\hline $\mathrm{Ta}$ & 5 & & $1.1 \pm 0.13$ & \\
\hline $\mathrm{Tb}$ & 6 & & $1.2 \pm 0.31$ & \\
\hline Th & 8 & $10.5 \pm 0.55$ & & \\
\hline $\mathrm{Tl}$ & 1 & & & 8.3 \\
\hline $\mathrm{Tm}$ & 2 & & & $0.34-0.56$ \\
\hline $\mathbf{U}$ & 10 & $48.8 \pm 6.5$ & & \\
\hline V & 20 & $160 \pm 21$ & & \\
\hline W & 1 & & & 3.3 \\
\hline$Y$ & 17 & $40.6 \pm 6.5$ & & \\
\hline $\mathrm{Yb}$ & 9 & $3.4 \pm 0.46$ & & \\
\hline $\mathrm{Zn}$ & 23 & $64.1 \pm 6.9$ & & \\
\hline$\underline{Z}$ & 17 & $165 \pm 24$ & & \\
\hline \multicolumn{5}{|c|}{$\begin{array}{l}\text { Analysis of variance with bottle as classification variable could not be calculated if laboratories reported only bottle } \\
\text { averages or if variance was zero due to failure to report all significant figures. } N 1<N \text { always. }\end{array}$} \\
\hline
\end{tabular}

and Urban and Stribrny (1989) attempted to use chemical data to define a normalized mineralogy of shales with their "Normative Mineral Compositions" (fig. 2). This technique provides a standardized norm for black shales. As Stribrny and Urban pointed out, the fine-grained nature of these rocks makes quantitative mineralogic determinations difficult to impossible. They noted that their technique necessarily ignores the presence of certain minerals, such as potassium feldspar, by allocating all potassium to illite and muscovite. Similarly, magnesium- and iron-chlorites were used instead of smectites. One disconcerting omission is the possibility that sulfate is present. (Barite is accounted for, but the presence of anhydrite could distort pyrite content.) Theirs is a useful attempt to provide some mineralogical context for study of black shales. Specific knowledge of clay mineralogy is useful in understanding shale evolution. In particular, smectite/illite transitions are useful where observed, and the residence of metals in certain clar's needs to be better understood (see, for example, Kucha, 1985, in the Kupferschiefer). For example, the illites in the Flowerpot Shale are $2 \mathrm{M}$ polytype; thus, they are detrital, not authigenic (Huyck and Chorey, 1989). Presence of $1 \mathrm{M}$ illites, which form diagenetically, may constrain the burial history of shale (for example, the Chainman Shale; Christensen, 1975).

Geochemistry includes several factors. In addition to standard XRF, ICP or NAA analyses, carbonate carbon content, total organic carbon content (TOC), sulfide sulfur content (versus total sulfur), and degree of pyritization (DOP) are critical for characterizing these shales. Simply looking at a low-calcium shale (Quinby-Hunt and others, 1989) is not sufficient for finding low-carbonate samples. (What about siderite or dolomite?) Additionally, th $\div$ Polish Kupferschiefer contains significant carbonate, and yet 
Table 5. Comparison of SDO-1 with other shale composites

[N/A indicates not applicable; blank or leaders (-), indicate not analyzed. Asterisk $\left(^{*}\right)$ indicates recommended value (see table 4); dorble asterisk $\left({ }^{* *}\right)$ indicates range midpoint (see table 4 ); triple asterisk $\left({ }^{* * *}\right)$ indicates SDO-1 value for $\mathrm{Be}, \mathrm{Co}, \mathrm{U}, \mathrm{Mo}$ is less than $\mathrm{V}+\mathrm{T}-\mathrm{B}^{\sim} \mathrm{C}$.

"minimum enrichment value" for "metal-rich shales"; $1 \mathrm{X}$ is shown to define "metalliferous"]

\begin{tabular}{|c|c|c|c|c|c|c|c|c|c|}
\hline & $\begin{array}{l}\text { SDO-1 } \\
\text { (table 4) }\end{array}$ & & $\begin{array}{c}\mathrm{V}+\mathrm{T} \\
\mathrm{BSC} \\
\text { (mean) } 1\end{array}$ & $\operatorname{NASC}^{2,3,4}$ & $\begin{array}{c}\text { MSG } \\
\text { BSC } \\
\text { (mean) }^{2}\end{array}$ & $\mathrm{ES}^{3}$ & PAAS $^{3,2}$ & $\begin{array}{l}\text { SDO-1 } \\
\text { "metal- } \\
\text { liferous" }\end{array}$ & $\begin{array}{l}\mathrm{V+T-BSC} \\
\text { "metal- } \\
\text { rich" } \\
\end{array}$ \\
\hline \multicolumn{10}{|c|}{ MANOR ELFMENIS OR OXIDES IN WEIGIIT PERCENT } \\
\hline$\overline{\mathrm{SiO}_{2}}$ & 49.28 & $\mathbf{S i}$ & & & & & & & \\
\hline $\mathrm{Al}_{2} \mathrm{O}_{3}$ & 12.27 & $\mathrm{Al}$ & 7.0 & 8.90 & 8.21 & & 10.00 & & \\
\hline $\mathrm{Fe}_{2} \mathrm{O}_{3}(\mathrm{tot})$ & 9.34 & $\mathrm{Fe}$ & 2.00 & 4.00 & 3.68 & & 5.00 & & \\
\hline $\begin{array}{l}\mathrm{CaO} \\
\mathrm{MgO} \\
\mathrm{Na}_{2} \mathrm{O}\end{array}$ & $\begin{array}{l}1.05 \\
1.54 \\
0.38\end{array}$ & $\begin{array}{l}\mathrm{Ca} \\
\mathrm{Mg} \\
\mathrm{Na}\end{array}$ & $\begin{array}{l}1.5 \\
0.7 \\
0.7\end{array}$ & $\begin{array}{l}2.50 \\
1.70 \\
0.75\end{array}$ & $\begin{array}{l}1.71 \\
1.04 \\
0.526\end{array}$ & & $\begin{array}{l}0.93 \\
1.30 \\
0.89\end{array}$ & N/A & \\
\hline $\mathrm{K}_{2} \mathrm{O}$ & 3.35 & $\mathbf{K}$ & 2.00 & 3.20 & 2.99 & & 3.10 & & \\
\hline $\mathrm{P}_{2} \mathrm{O}_{5}$ & 0.11 & $\mathbf{P}$ & & & & & & & \\
\hline $\mathrm{TiO}_{2}$ & 0.71 & $\mathrm{Ti}$ & 0.2 & 0.420 & 0.434 & & 0.600 & & 0.7 \\
\hline $\mathrm{MnO}$ & 0.0419 & $\mathrm{Mn}$ & 0.015 & 0.046 & 0.038 & & 0.085 & 0.0644 & 0.1 \\
\hline LOI & 21.7 & & & & & & & & \\
\hline $\mathbf{S}$ & 5.35 & & & & & & & & \\
\hline $\mathrm{CO}_{2}$ & 1.01 & & & & & & & & \\
\hline C total & 9.95 & & & & & & & & \\
\hline C mineral & & & 0.33 & & & & & & \\
\hline C org(meas) & $9.69 * *$ & & 3.2 & & & & & & \\
\hline C org(calc) & 9.678 & & & & & & & & \\
\hline \multicolumn{10}{|c|}{ RARE-EARTH ELEMENTS IN PARTS PER MILLION } \\
\hline $\mathrm{La}$ & 38.5 & & 30 & 32 & 44 & 41.1 & 38 & 77.0 & 70 \\
\hline $\mathrm{Ce}$ & 79.3 & & & 73 & 80 & 81.3 & 80 & 158.6 & \\
\hline $\operatorname{Pr}$ & 8.9* & & & 7.9 & & 10.4 & 8.9 & 19.8 & \\
\hline $\mathrm{Nd}$ & 36.6 & & & 33 & 55 & 40.1 & 32 & 73.2 & \\
\hline $\mathrm{Sm}$ & 7.7 & & & 5.7 & 6.2 & 7.3 & 5.6 & 15.4 & \\
\hline $\mathrm{Eu}$ & $1.6^{*}$ & & & 1.24 & 1.27 & 1.52 & 1.1 & 3.2 & \\
\hline $\mathrm{Gd}$ & $6.5 *$ & & & 5.2 & & 6.03 & 4.7 & 13.0 & \\
\hline $\mathrm{Tb}$ & $1.2^{*}$ & & & 0.85 & 0.95 & 1.05 & 0.77 & 2.4 & \\
\hline Dy & $6.0^{*}$ & & & 5.8 & 4.85 & & 4.4 & 11.4 & \\
\hline Ho & $1.2 *$ & & & 1.04 & & 1.20 & 1.0 & 0.2 & \\
\hline Er & $3.6 * *$ & & & 3.4 & & 3.55 & 2.9 & 7.2 & \\
\hline $\mathrm{Tm}$ & $0.45 * *$ & & & 0.50 & & 0.56 & 0.40 & 0.90 & \\
\hline $\mathrm{Yb}$ & 3.4 & & & 3.1 & 3.10 & 3.29 & 2.8 & 6.8 & \\
\hline$\underline{\mathbf{u}}$ & 0.54 & & & 0.48 & 0.47 & 0.58 & 0.43 & 1.04 & \\
\hline
\end{tabular}

should not be excluded from black shales. Shales that host disseminated gold deposits of the Great Basin may intrinsically contain significant amounts of carbonate (Bloomstein and Clark, this volume).

Obviously, organic carbon content is critical, especially if it is the basis for defining a black shale. However, the weight percent alone does not provide sufficient information. At a minimum, type of organic content and thermal maturity must be known. Currently, some researchers consider the distinction between humic and sapropelic carbon to be critical to understanding metal associations. B. Kribek (Charles University, Czechoslovakia, written commun., 1990) goes so far as to prefer that humic-rich shales be excluded from the definition of black shales. Kukal noted but rejected this at the inaugural
IGCP 254 meeting (Kukal, 1988). Speczik ant Puttman (1987) pointed out that the Kupferschiefer locall'" contains significant amounts of humic organic material, yet this shale should not be excluded from the grouping. Sapropelic and humic materials, however, may be associated with different metals, and this hypothesis should be tested whenever possible. Rock-Eval pyrolysis (fig. 3) is a common method that permits at least a first attempt to make this distinction. Researchers commonly provide detailed organic descriptions (Poole and Claypool, 1984), correlation of total organic carbon content and metals (Desborough and others, this volume), or crosscorrelations of metals (Frost and Chou, 1983) but rarely a combination of these. Combining these traits with organic matter petrography would fill a major gap in understanding metalliferous shales. 
Table 5. Continued

\begin{tabular}{|c|c|c|c|c|c|c|c|}
\hline & $\begin{array}{l}\text { SDO-1 } \\
\text { (table 4) }\end{array}$ & $\begin{array}{c}\mathrm{V}+\mathrm{T} \\
\mathrm{BSC} \\
\text { (mean) }\end{array}$ & NASC $2,3,4$ & $\begin{array}{c}\text { MSG } \\
\text { BSC } \\
(\text { mean })^{2}\end{array}$ & PAAS $^{3,2}$ & $\begin{array}{l}\text { SDO-1 } \\
\text { "metal- } \\
\text { liferous" }\end{array}$ & $\begin{array}{l}\text { V+T-BSC } \\
\text { "metal- } \\
\text { rich"1 }\end{array}$ \\
\hline \multicolumn{8}{|c|}{$\begin{array}{l}\text { TRACE ELFMENIS IN PARTS PER MILLION } \\
\end{array}$} \\
\hline $\mathrm{Ag}$ & $0.131 * *$ & $<1$ & -- & $\ldots$ & -- & 0.262 & 7 \\
\hline As & 68.5 & -- & 28.4 & 28.8 & -- & 137 & -- \\
\hline All & $0.0028 * *$ & -- & -- & 0.023 & -- & 0.0056 & -- \\
\hline B & 128 & 50 & - & -- & & 256 & $2(0)$ \\
\hline $\mathrm{Ba}$ & 397 & 300 & 636 & 1,720 & 650 & 694 & $1,0(?)$ \\
\hline $\mathrm{Be}$ & 3.3 & 1 & -- & - & -- & $3.3 * * *$ & 3 \\
\hline $\mathrm{Bi}$ & $5 * *$ & -- & -- & -- & -- & 10 & -. \\
\hline $\mathrm{Br}$ & $5 * *$ & -- & 0.69 & 4.0 & -- & 10 & -- \\
\hline $\mathrm{Cd}$ & $5 * *$ & -- & -- & -- & -- & 10 & -- \\
\hline $\mathrm{Cl}$ & $116^{*}$ & -- & -- & 240 & -- & 232 & -- \\
\hline Co & 46.8 & 10 & 25.7 & 16.9 & 23 & $46.8^{* * *}$ & 30 \\
\hline $\mathrm{Cr}$ & $66.4^{*}$ & 100 & 124.5 & 111 & 110 & 132.8 & $7(?$ \\
\hline Cs & $6.9 *$ & -. & 5.16 & 8.6 & 15 & 13.8 & -- \\
\hline $\mathrm{Cu}$ & $60.2^{*}$ & 70 & -- & -- & -- & 120.4 & 209 \\
\hline $\mathrm{Er}$ & $3.6 * *$ & -- & -- & -- & -- & 7.2 & -- \\
\hline $\bar{F}$ & $0.035 * *$ & -- & -- & -- & -- & 0.07 & -. \\
\hline $\mathrm{Ga}$ & 16.8 & 20 & - & 21.9 & 85 & 33.6 & $\leq 0$ \\
\hline Ge & $1.3 * *$ & -- & -- & -- & -- & 2.6 & - \\
\hline $\mathrm{Hf}$ & $4.7^{*}$ & -- & 6.30 & 4.3 & 5.0 & 9.4 & -- \\
\hline $\mathrm{Hg}$ & $2.2 * *$ & -- & -- & -- & -- & 4.4 & -- \\
\hline In & $0.1 * *$ & -- & -- & 0.21 & -. & 0.2 & -- \\
\hline $\mathrm{Li}$ & 28.6 & .- & -- & -- & .. & 56.2 & -- \\
\hline Mo & 134 & 10 & -- & 65 & 1.0 & $134^{* * *}$ & 200 \\
\hline $\mathrm{Nb}$ & 11.4 & $\ldots$ & -- & -- & $\ldots$ & 22.8 & -- \\
\hline $\mathrm{Ni}$ & 99.5 & 50 & 58 & .- & -- & 199.0 & 300 \\
\hline $\mathrm{Pb}$ & 27.9 & 20 & -- & -- & -- & 55.8 & 100 \\
\hline $\mathrm{Rb}$ & $126^{*}$ & -- & 125 & 131 & 160 & 252 & -- \\
\hline $\mathrm{Sb}$ & $4.45 * *$ & -- & 2.09 & 5.7 & -- & 8.9 & -- \\
\hline Sc & 13.2 & 10 & 14.9 & 15.6 & 16 & 26.4 & $\therefore 0$ \\
\hline $\mathrm{Se}$ & $4.9 * *$ & -- & -- & 5.6 & -- & 9.8 & \\
\hline Sn & $29 *$ & -. & -. & -- & & 58 & \\
\hline $\mathrm{Sr}$ & 75.1 & 200 & 142 & 310 & 200 & 150.2 & 1,500 \\
\hline $\mathrm{Ta}$ & $1.1^{*}$ & - & 1.12 & 0.9 & -. & 2.2 & .. \\
\hline Th & 10.5 & -- & 12.3 & 11.6 & 14.6 & 21.0 & -. \\
\hline $\mathrm{Tl}$ & $8.3 * *$ & -- & -- & -- & -- & 16.6 & -- \\
\hline U & 48.8 & 2 & 2.66 & 15.2 & 3.1 & $48.8^{* * *}$ & 30 \\
\hline V & 160 & 150 & -- & 500 & 150 & 320 & 1,000 \\
\hline W & $3.3 * *$ & -- & 2.1 & 3.3 & 2.7 & 6.6 & - \\
\hline $\mathrm{Y}$ & 40.6 & 30 & - & -- & -- & 81.2 & 70 \\
\hline $\mathrm{Zn}$ & 64.1 & $<300$ & -- & 310 & 85 & 128.2 & 1,500 \\
\hline $\mathrm{Zr}$ & 165 & 70 & 200 & 230 & 210 & 330 & 200 \\
\hline
\end{tabular}

Thermal maturity of organic sedimentary rocks is similarly important. For example, Kribek (1989) noticed that as a sapropelic black shale is metamorphosed, decreasing As, $\mathrm{Mo}, \mathrm{Pb}, \mathrm{U}, \mathrm{V}, \mathrm{Zn}, \mathrm{Sb}, \mathrm{Ag}$, and $\mathrm{Au}$ contents indicate mobilization of these metals. In fact, Kribek considered the metal concentrations to vary more strongly with chemical maturity and metamorphic grade than with total organic carbon content. Poole and Claypool (1984) focused on the petroleum potential in black shales in the Great Basin and noted that organic matter had moved out of these shales in certain parts of the basin. This mobil'ty is the reason why shale that was once "black" may now contain less than 0.3 percent total organic carbon. Thus, thermal maturity affects both organic carbon and metal contents in shale. Initial attempts to determine thermal maturity may use the correlation of different methods, as presented by Poole and Claypool (1984) and shown on figure 4. Additional measures of thermal maturity of shale include crystallinity of authigenic illite and degree of graphitization. Illite crystallinity provides relative comparison of thermal 
Table 6. U.S. Working Group IGCP Project 254, Metalliferous Black Shales

[Modified after Zimmerle and Stribmy, 1989]

NAME

LOCATION

STRATIGRAPHIC POSITION

Scale of variation

REGIONAL DISTRIBUTION

THICKNESS

PETROGRAPHY

Grain size/texture

Fabric

Organic material identification (inertinite/vitrinite, etc.)

MINERALOGY

GEOCHEMISTRY

Organic carbon and carbonate carbon

Sulfide sulfur

Degree of pyritization (DOP)

Major, minor, and trace elements

Organic geochemistry

Organic type (e.g. sapropelic/humic; biomarkers)

Thermal maturity (diagenesis/catagenesis/metamorphism)

\section{PALEONTOLOGY}

Bioturbation

Identification and compactional features

DEPOSITIONAL ENVIRONMENT, FACIES

COLOR

FURTHER REMARKS

REFERENCES

AUTHOR(S)

maturity, although it has not been correlated with the indicators shown in figure 4. (Definitions for types of organic material are also vague; for example, the term bitumen is used in a variety of contexts.) Degree of graphitization is helpful for comparing metamorphosed shales. (Discussion of characterization or genesis of graphitic schists is not within the scope of this paper, although it is an issue that needs to be addressed.)
Finally, a critical analysis is DOP, or degree of pyritization, defined as sulfide iron divided by the sum of sulfide iron and acid-soluble iron. Plots of organic carbon versus DOP are a refinement of carbon versus si lfur plots, which are themselves useful for distinguishing among lake sediments, normal marine sediments, and euxiric marine sediments (Berner and Raiswell, 1983; Leventhal, 1983) (fig. 5). As Berner, Raiswell, and associates heve shown 


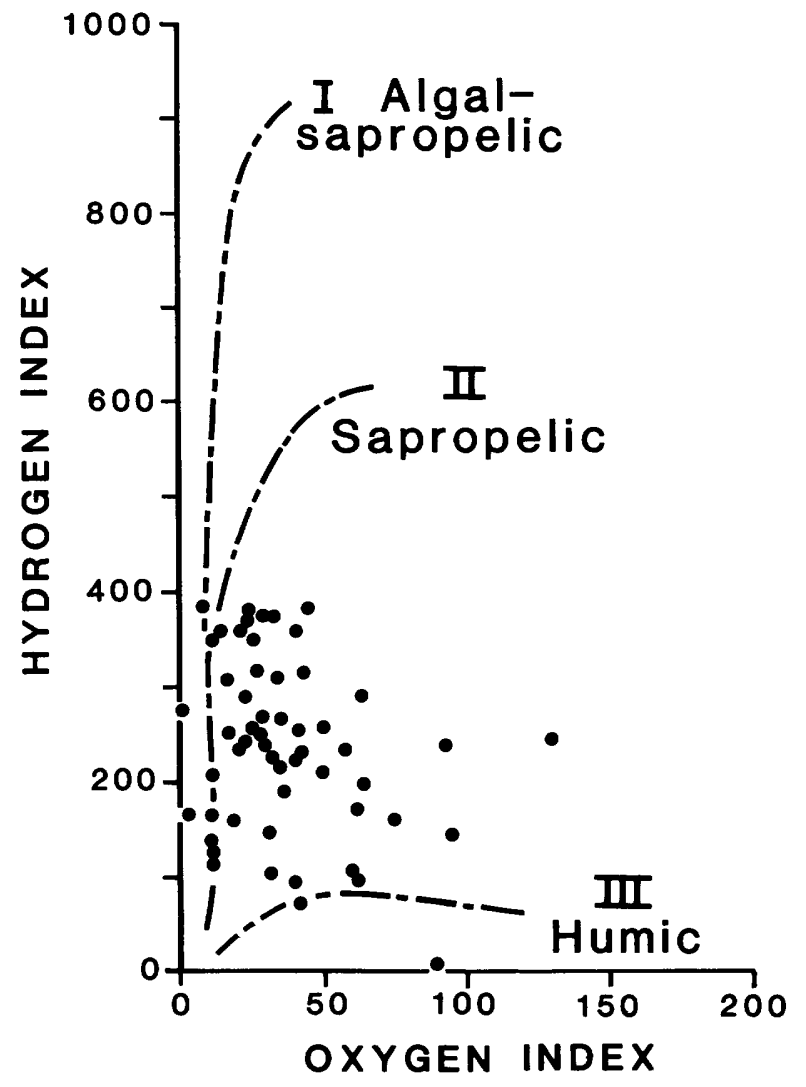

Figure 3. Plot of hydrogen index versus oxygen index for different kerogen types in Chainman Shale cuttings (Poole and Claypool, 1984, fig. 14), as an example of information provided by Rock-Eval analysis. Note different types of kerogen source. Main types of kerogen show evolution paths toward the origin as maturity increases. Hydrogen index is milligrams of hydrocarbons per gram of organic carbon; oxygen index is milligrams $\mathrm{CO}_{2}$ per gram organic carbon.

(figs. 6, 7), measurement of DOP also differentiates the timing of pyrite formation (syngenetic versus diagenetic) and the limiting factor on pyrite formation (iron versus carbon). Because certain trace metals are strongly associated with sulfide minerals, understanding the timing and conditions of sulfide formation is critical.

A brief description of the proposed standard SDO-1 is available and includes some of the characteristics noted above. SDO-1, Ohio Shale (Devonian), is a "brownishblack (5YR2/1) shale" (Kepferle and others, 1985) sampled from a 3.05-m-thick zone in the lower part of the Huron Member of the Ohio Shale. The sample locality is a roadcut on Interstate 64 , approximately $13.7 \mathrm{~km}(8.5 \mathrm{mi})$ west of Morehead in western Rowan County, Kentucky ("Locality A" in Kepferle, 1986). Provo and others (1977) described the shale as fissile, brittle, pyritic, and containing fossils such as Tasmanites, conodonts, and woody plant fragments. Thin section analysis (Kepferle and others, 1985, table 7) indicates an organic-rich mudshale (using the shale classification in table 2) in which quartz-rich, silty laminae
Table 7. Modal contents of SDO-1 [In percent. From Kepferle and others (1985)]

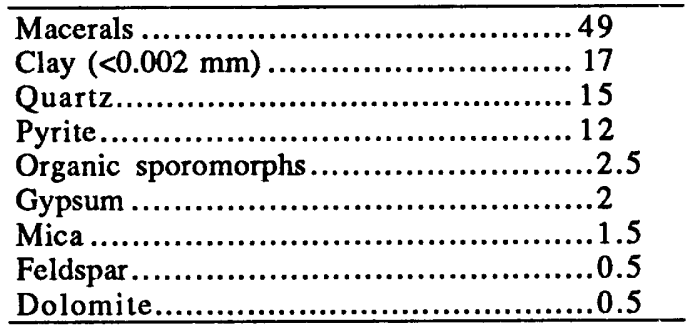

contain scattered conodonts. R. Schultz (University of Cincinnati, oral commun., 1990) has obtained a DOP of 0.71, and J.S. Leventhal and C. Taylor (U.S. Geological Survey, oral commun., 1990) have obtained DOP's tetween 0.74 and 0.78 (three determinations).

I consider the above characteristics to be essential for proper comparison among black shales and metalliferous black shales. Once these parameters have been dete 'mined, more sophisticated analyses, including stable isotopic studies, organic geochemistry, organic oxidation/polymerization (Speczik and Puttman, 1987, 1989), trace metal crosscorrelation, residences of metals in minerals and organics, metal associations (sapropelic versus humic) and mobilities, and modelling of metal behavior in blacl- shales can be attempted. Otherwise, we risk comparing the sedimentary versions of apples, oranges, and rutabagas. Recent studies have moved in this direction as techniques become more accessible; however, we are by no means finished. Raising these issues as part of the questior of just how to define a metalliferous black shale, and in the hope of filling the gaps in some of the mineralogical and geochemical studies already accomplished, will be another step toward understanding how black shales and, partirularly, metalliferous black shales form.

Acknowledgments.-Many of the references used in this paper and comments or suggestions have come from participants in the IGCP Project 254. Thanks go to the following, in alphabetical order: Robert W. Chorey, Fan Delian, George Desborough, C.S. Ferris, Eric Force, Richard Grauch, Roy Kepferle, Bohdan Kribek, Zdenek Kukal, Joel Leventhal, Michael Lewan, Timothy Lyons, Edwin K. Maughan, J. Barry Maynard, Jan Pasava, Paul E. Potter, Forrest G. Poole, Richard B. Schultz, and John Trammell for their written comments. The views expressed, however, are solely mine.

\section{REFERENCES CITED}

American Society for Testing and Materials, 1978, Standard specifications for classification of coals by rank (ASTM designation D388-77): 1978 Annual Book of AST ${ }^{\wedge}$ Standards, pt. 26, p. 220-224. 


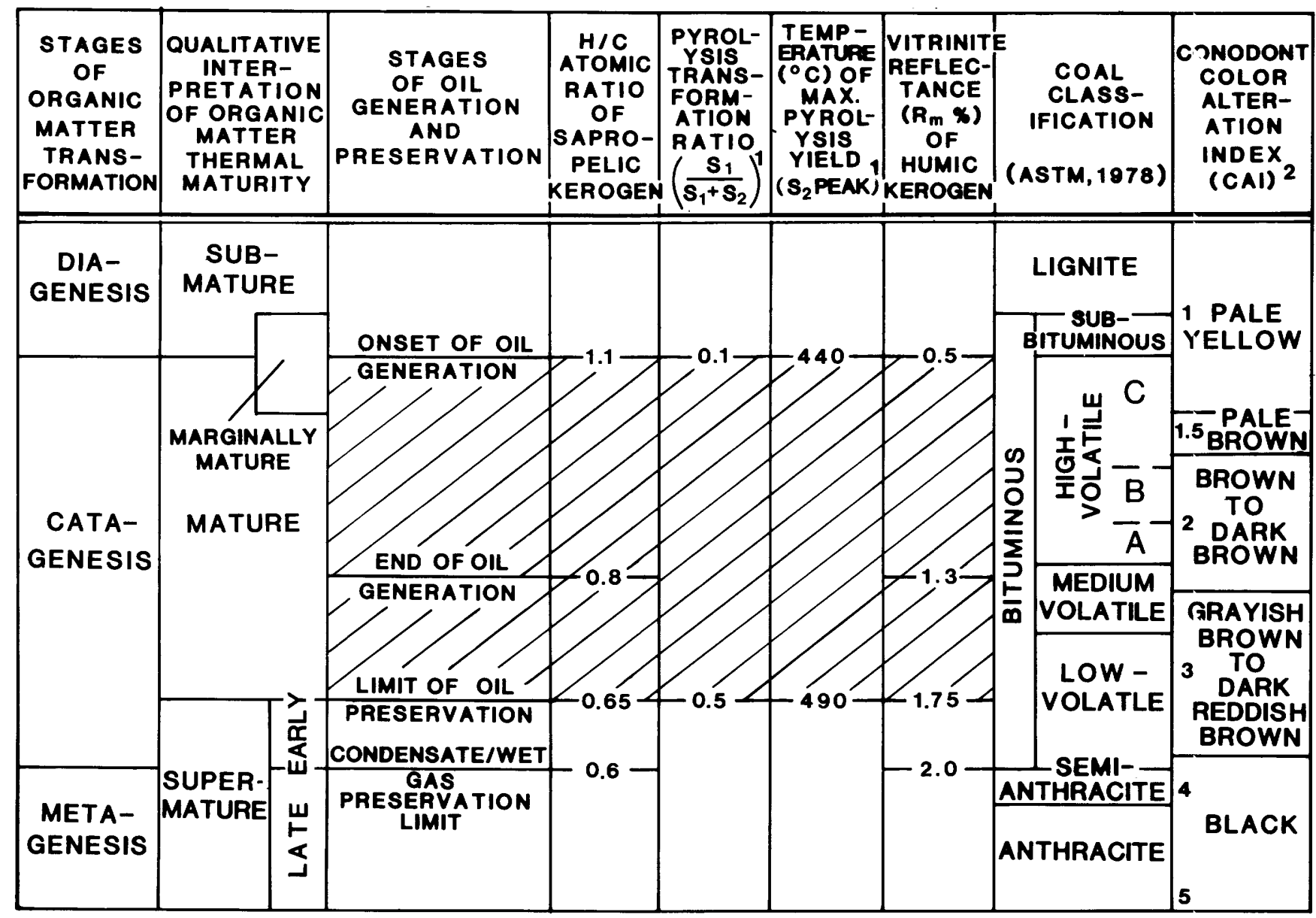

$1 S_{1} / S_{1}+S_{2}$ ratio and $S_{2}$ peak $\left(T_{\max }{ }^{\circ} \mathrm{C}\right.$ ) applicable only to mature and submature kerogen.

2 Epstein and others $(1977)$.

Figure 4. Various geochemical indicators of thermal maturity of organic material and stages of hydrocarbon gen?ration and preservation. Modified from Poole and Claypool (1984, fig. 9).

Arthur, M.A., 1979, North Atlantic Cretaceous black shales-The record at site 398 and a brief comparison with other occurrences: Initial Reports of the Deep Sea Drilling Project, v. 47, pt. 2, p. 719-751.

Baker, D.R., and Claypool, G.E., 1970, Effects of incipient metamorphism on organic matter in mudrock: American Association of Petroleum Geologists Bulletin, v. 54, p. $456-468$.

Bates, R.L., and Jackson, J.A., 1987, Glossary of geology (3rd ed.): American Geological Institute, Alexandria, $788 \mathrm{p}$.

Berner, R.A., and Raiswell, R., 1983, Burial of organic carbon and pyrite sulfur in sediments over Phanerozoic time-A new theory: Geochimica et Cosmochimica Acta, v. 47. p. 855-862.

Brumsack, H.J., 1980, Geochemistry of Cretaceous black shales from the Atlantic Ocean (DSDP Legs 11, 14, 36, and 41): Chemical Geology, v. 31, p. 1-25.

Christensen, O.D., 1975, Metamorphism of the Manning Canyon and Chainman Formations: Geological Society of America Abstracts with Programs, v. 7, no. 3, p. 303-304.
Craig, J.C., Vaughan, D.J., and Skinner, B.J., 1988, Pesources of the Earth: Englewood Cliffs, New Jersey, Prentice Hall, p. 366-367.

Degens, E.T., 1965, Geochemistry of sediments-A brief summary: Englewood Cliffs, New Jersey, P'sntice-Hall, 342 p.

Degens, E.T., Meyers, P.A., and Brassell, S.C., eds., 1986, Biogeochemistry of black shales: Mittleilung?n aus dem Geologisch-Palaontologischen Institut der Universitat Hamburg, Heft 60, SCOPE/UNEP Sonderbans 253 p.

Droser, M.L., and Bottjer, D.J., 1986, A semiquantitative field classification of ichnofabric: Journal of Sedimentary Petrology, v. 56, no. 4, p. 558-559.

Epstein, A.G., Epstein, J.B., and Harris, L.D., 1977, Conodont color alteration-An index of organic metamoiphism: U.S. Geological Survey Professional Paper 995, 27 p.

Frost, J.K., and Chou, C.L., 1983, Trace element geochemistry of the New Albany Shale Group (Devonian-Mis -issipian) in Illinois-Implications for depositional envirorment: 1983 Eastern Oil Shale Symposium, University of Kentucky 


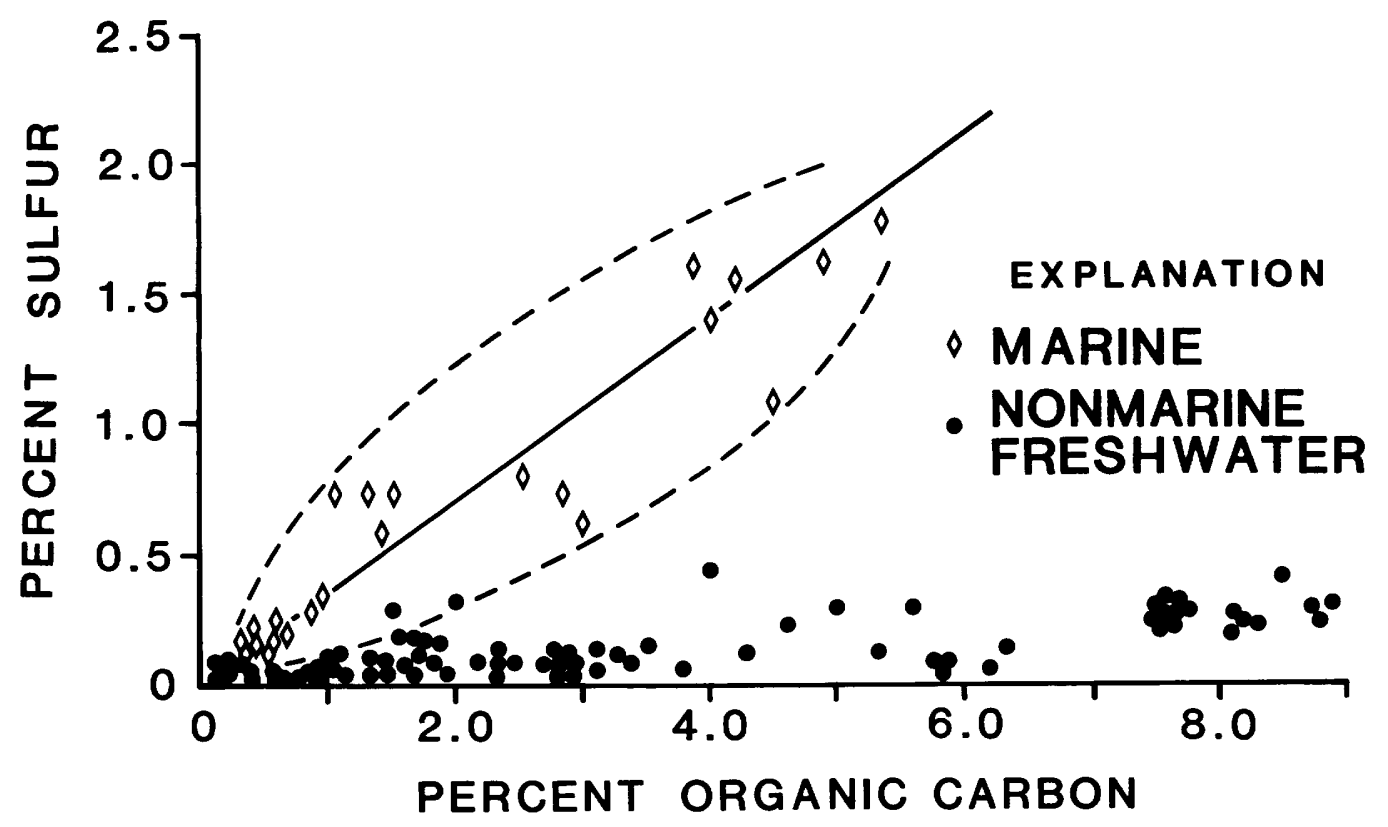

Figure 5. Organic carbon versus reduced sulfur for modern freshwater lake sediments (Leventhal, 1983) and normal marine sediments (Berner and Raiswell, 1983, fig. 2).

Institute for Mining and Minerals Research and the Kentucky Energy Cabinet, p. 181-194.

Green, J., 1959, Geochemical table of the elements for 1959: Geologic Society of America Bulletin, v. 70, no. 9, p. 1127-1183.

Gromet, P.L., Dymek, R.F., Haskin, L.A., and Korotev, R.L., 1984, The "North American shale composite"-Its compilation, major and trace element characteristics: Geochimica et Cosmochimica Acta, v. 48, p. 2469-2482.

Huyck, H.L.O., and Chorey, R.W., 1989, Stratigraphic comparison of Creta and Kupferschiefer copper shales-Applications to mineralizing models: International Geological Congress, 28th, Washington, D.C., Abstracts, v. 2, p. 90.

Kane, J., Arbogast, B., and Leventhal, J., 1990, Characterization of Devonian Ohio Shale SDO-1 as a USGS Geochemical Reference Standard: Geostandards Newsletter, v. 14, no. 1, p. 169-196.

Kepferle, R.C., 1986, Devonian and Mississippian black shales of Kentucky: Geological Society of America Centennial Field Guide-Southeastern Section, p. 31-36.

Kepferle, R.C., de Witt, W., Jr., and Flanagan, F.J., 1985, Ohio Shale (Devonian), SDO-1 from Rowan County, Kentucky: U.S. Geological Survey Open-File Report 85-145, 14 p.

Krauskopf, K.B., 1979, Introduction to geochemistry (2nd ed.): New York, McGraw-Hill, p. 544-546.

Kribek, B., 1989, Lithological and metamorphic development of anoxic environment in geological history of the Bohemian Massif: International Geological Congress, 28th, Washington, D.C., Abstracts, v. 2, p. 228.

Kucha, H., 1985, Feldspar, clay, organic and carbonate receptors of heavy metals in Zechsteicn deposits (Kupferschiefertype), Poland: Institution of Mining and Metallurgy Transactions, sec. B, v. 94, p. B133-B146.

Kukal, Z., 1988, Deposition of black shales-Why, where and when? (with special attention to the Bohemian Massif), in
Pasava, J., and Gabriel, Z., eds., Proceedings of the Inaugural Meeting of the IGCP 254: Geological Survey of Czechoslovakia, Prague, p. 51-55.

Leventhal, J.S., 1983, An interpretation of carbon ant sulfur relationships in Black Sea sediments as indicators of envirnoments of deposition: Geochimica et Cosmcchimica Acta, v. 47, p. 133-137.

Lewan, M.D., 1987, Petrographic study of primary petroleum migration in the Woodford Shale and related rock units, in Doligez, B., ed., Migration of hydrocarbons in sedimentary basins: Institut Francais du Petrole Collection Coll xques et Seminaires 45, p. 113-130.

Poole, F.G., and Claypool, G.E., 1984, Petroleum sou-ce-rock potential and crude-oil correlation in the Great $\mathrm{F}$ ?sin, in Woodward, J., Meissner, F.F. and Clayton, J.I.,, eds., Hydrocarbon source rocks of the Greater Rocky Mountain Region: Rocky Mountain Association of Geslogists, Denver, Colorado, p. 179-229.

Potter, P.E., Maynard, J.B., and Pryor, W.A., 1980, Sedimentology of shale: New York, Springer-Verlag, 306 p.

Provo, L.J., Kepferle, R.C., and Potter, P.E., 1977, Three Lick Bed-Useful stratigraphic marker in Upper Devonizn Shale in eastern Kentucky and adjacent areas of Ohi3, West Virginia, and Tennessee: U.S. Energy Research and Development Administration, Morgantown Energy Research Center Report MERC/CR-77-2, 56 p.

Quinby-Hunt, M.S., Wilde, P., Orth, C.J., and Berry, W.B.N., 1989, Elemental geochemistry of black shales-S atistical comparison of low-calcic shales and other shales: U.S. Geological Survey Circular 1037, p. 8-15.

Raiswell, R., and Berner, R.A., 1985, Pyrite formation in euxinic and semi-euxinic sediments: American Journal of Science, v. 285 , p. $710-724$. 

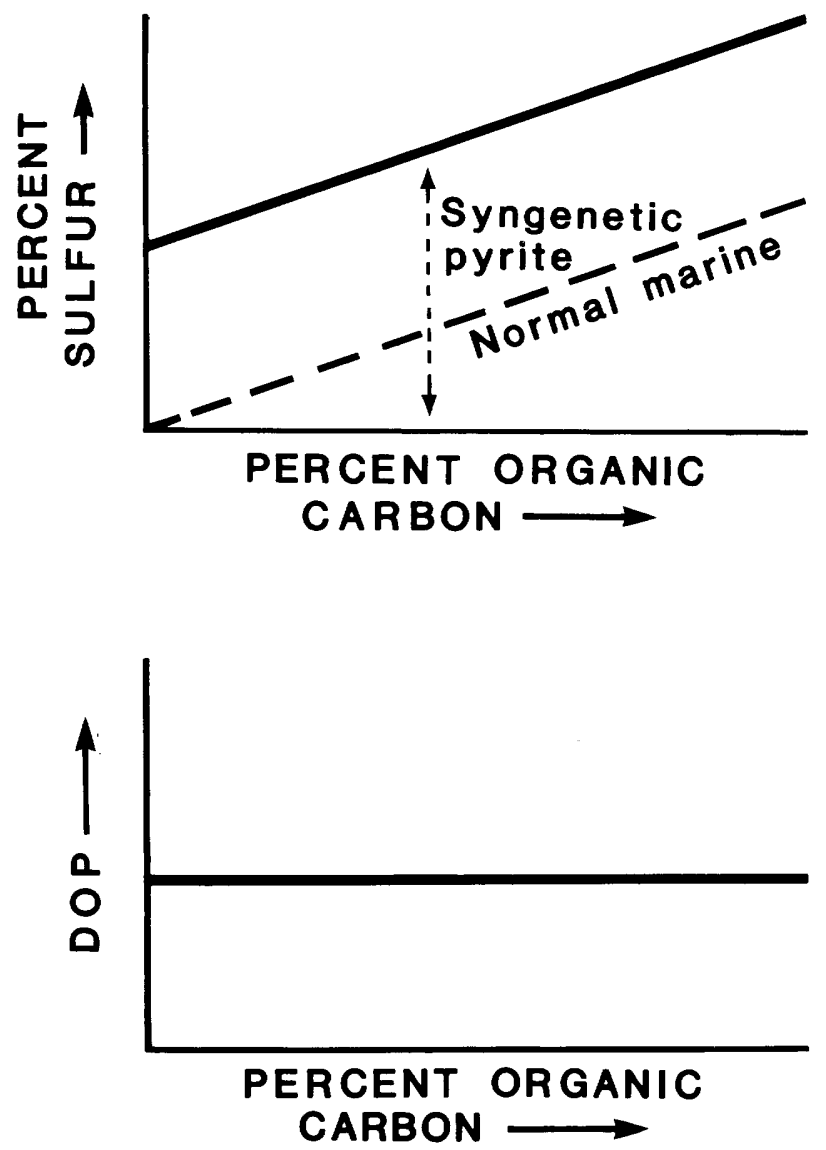

Figure 6. Idealized plots of organic carbon versus pyrite sulfur (percent sulfur) and degree of pyritization (DOP) for a hypothetical euxinic sediment. The plots show formation of iron-limited syngenetic pyrite alone, as indicated by a uniform DOP as organic carbon content increases. The heavy dashed line is that expected for a normal marine sediment, as in figure 5 . Modified from Raiswell and Berner (1985, fig. 2).

1987, Organic carbon losses during burial and thermal maturation of normal marine shales: Geology, v. 15 , p. 853-856.

Spears, D.A., 1980, Towards a classification of shales: Journal of the Geological Society, v. 137, p. 123-130.

Speczik, S., and Puttman, W., 1987, Origin of Kupferschiefer mineralization as suggested by coal petrology and organic geochemical studies: Acta Geologica Polonica, v. 37, no. 3-4, p. 167-187.

1989, Oxidation of organic matter and its influence on Kupferschiefer mineralization of southwestern Poland: International Geological Congress, 28th, Washington, D.C., Abstracts, v. 3, p. 160.

Stribrny, B., and Urban, H., 1989, Classification of sedimentary rocks in the black shale series based on their normative mineral compositions: International Geological Congress, 28th, Washington, D.C., Abstracts, v. 3, p. 190-191.

Taylor, S.R., and McLennan, S.M., 1988, The significance of the rare earths in geochemistry and cosmochemistry, in Gschneidner, K.A., Jr., and Eyring, L., eds., Handbook on
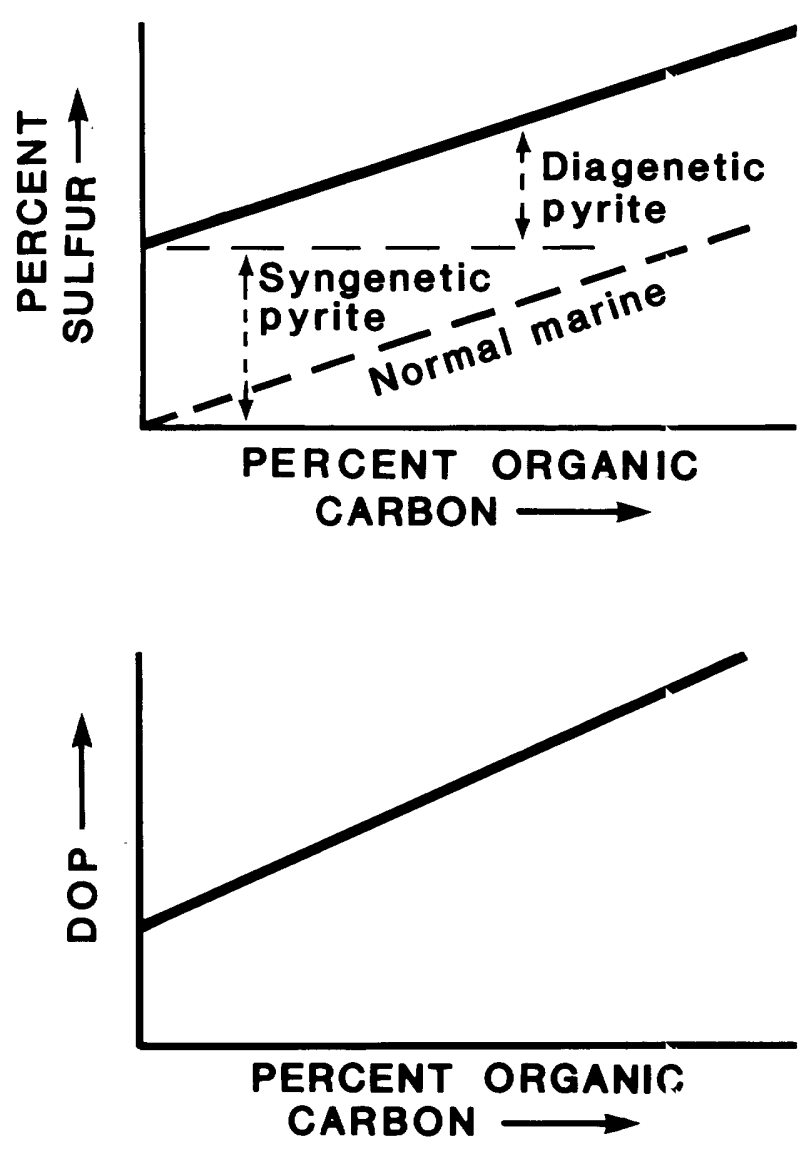

Figure 7. Idealized plots of organic carbon versus pyrite sulfur (percent sulfur) and degree of pyritization (DOP) for a hypothetical euxinic environment, as in figure 6 . These plots show formation of extra carbon-limited diagenetic pyrite, as indicated by the increase in DOP as organic carbon content increases. Modified from Raiswell and Berner (1985, fig. 1).

the physics and chemistry of rare earths, v. 11: New York, Elsevier, p. 485-578.

Tourtelot, H.A., 1960, Origin and use of the word "shale": American Journal of Science, v. 258-A, p. 335--343.

Urban, H., and Stribrny, B., 1989, On the classificat ion of black shales: Terra Abstracts, v. 1, p. 13.

Vine, J.D., and Tourtelot, E.B., 1970, Geochemistry of black shales-A summary report: Economic Geology, v. 65, p. 253-272.

Waples, D.W., 1983, Reappraisal of anoxia and organic richness, with emphasis on Cretaceous of North Atlantin: American Association of Petroleum Geologists Bulletin, v. 67, p. 963-978.

Zimmerle, W., and Stribrny, B., eds., 1989, Organic carbon-rich pelitic sediments in the Federal Republic of Germany, Diskussionsvorlage fur die 2. Arbeitstagung am 1.-2., Juni 1989 in Korbach: Institut fur Geochemie, Petrologie und Lagerstattenkunde, J.W. Goethe-Universitat Frankfurt, $25 \mathrm{p}$. 


\title{
Recent Black Sea Sediments-Leg 4, 1988 Black Sea Expedition
}

\author{
By Timothy W. Lyons
}

The Black Sea is the type euxinic basin and, as such, a frequently cited analog for the depositional environment of ancient black shales. Its strongly stratified water column is permanently anoxic and sulfidic below approximately $100 \mathrm{~m}$ (the $\mathrm{O}_{2} / \mathrm{H}_{2} \mathrm{~S}$ interface is somewhat deeper in the marginal regions of the basin). The 1988 R/V Knorr Black Sea Oceanographic Expedition provided a unique opportunity to investigate many aspects of this basin in great detail and, thus, to test the validity of the "Black Sea model." The principal objectives of this study are twofold: (1) an improved understanding of euxinicbasin sediments and pyrite formation (carbon-sulfur-iron systematics) and (2) comparison of the sediments of oxic and anoxic depositional settings in terms of chemistry and general sedimentology.

Box-core sediments collected during Leg 4 of the 1988 expedition reveal a variety of uppermost Holocene sedimentary facies sampled over a broad region of the southern Black Sea basin; cores are included from two transects across the intersection of the water-column oxicanoxic interface with the basin-margin substrate (Bay of Sinop region and immediately west of the Bosporus) (fig. 1, table 1). The sediments sampled during Leg 4 include: (1) muddy, gray turbidite layers in the deep basin from a few to several tens of centimeters thick and characterized by a predominance of fine grain sizes (fine-silt to clay) and remarkable textural and chemical homogeneity (stations $7,8,11,18 \mathrm{~A}$, and 19), (2) an array of closely spaced sediment types across the oxyclinesubstrate intersection varying from a highly bioturbated, shell-rich oxic facies to dark-gray to black, water-rich, laminated muds from the anoxic zone, and (3) coccolithrich, microlaminated sediments of the abyssal Black Sea consisting of couplets of alternating white (coccolith dominated) and dark-brown to black (siliciclastic dominated) millimeter-scale laminae (stations 9, 14, and 18A). These

\footnotetext{
${ }^{1}$ Department of Geology and Geophysics, Yale University, New Haven, Connecticut 06511.
}

microlaminated muds comprise the "Unit 1" sediment of the widely used Black Sea nomenclature scheme cf Ross and others (1970) and Ross and Degens (1974). The light-dark pairs may derive from variability in sedimentation occurring on a seasonal scale and, as a consecuence, may represent annual varve couplets. However, there currently exists an unresolved disparity between varve-count and radiometric age determinations for Unit 1.

The turbiditic mud layers display strongly conformable basal contacts that suggest negligible erosion associated with emplacement. The layers are in both stacked multiturbidite packages, including as many as eight separate "events" in approximately $50 \mathrm{~cm}$ of core, and sequences of interbedded turbidite mud and undisturbed Unit 1 "varved" material. These muds range from massive to moderately well laminated. Multiple corirg at a single station reveals dramatic local-scale variation in turbidite spatial relationships. The exact mechanism connected with the deposition of these muddy gray layers remains unknown. Sandy turbidites were encountered in the vicinities of stations $18 \mathrm{~A}$ and 19.

Superimposed on the relatively fine scale lamination of the basin-margin anoxic-zone sediments at stations 5 and 15 , as detected by $\mathrm{X}$-radiography, is a larger scale (several centimeters), enigmatic, black and dark-gray banding. The black pigments are a consequence of strong enrichments in acid-volatile iron monosulfides ("FeS"). These anomalous enrichments reflect, at least in p?rt, the high rates of sedimentation at these sites. Similarly, cores of gray-brown sediment from stations 16B and 26 of the Bay of Sinop transect contain black "FeS" banc's. The sediments of $16 \mathrm{~B}$ and 26 were deposited very proximal to the position of the oxic-anoxic interface at the time of coring at sites where bottom-water dissolved-oxygen concentrations were found to be at trace to null leve's. The sediments of $16 \mathrm{~B}$, as viewed in X-radiography, dirnlay a combination of discrete burrows, a shelly taxa, and a disturbed lamination-a very transitional characte- with respect to the oxic and anoxic end members of the transect. 
Table 1. Water depths at Leg 4 boxcoring stations

\begin{tabular}{cc}
\hline Station & $\begin{array}{c}\text { Water depth } \\
\text { (meters) }\end{array}$ \\
\hline 3 & 85 \\
4 & 115 \\
5 & 233 \\
7 & 1,949 \\
8 & 2,128 \\
& \\
9 & 2,094 \\
11 & 2,175 \\
14 & 2,218 \\
15 & 198 \\
16 & 129 \\
& \\
$16 \mathrm{~B}$ & 160 \\
17 & 97 \\
$18 \mathrm{~A}$ & 2,150 \\
19 & 1,620 \\
26 & 170 \\
\hline
\end{tabular}

A particularly well developed (and preserved) benthic-boundary flocculent layer ("fluff la:'er") was observed in the deeper water box cores. This fluff layer was found overlying both gray turbidite and Urit 1 muds. Varve packets, as well as individual laminae, v'ere correlated among several stations $(9,14$, and $18 \mathrm{~A})$ over a distance of approximately $500 \mathrm{~km}$.

\section{REFERENCES CITED}

Ross, D.A., and Degens, E.T., 1974, Recent sedimer's of Black Sea, in Degens, E.T. and Ross, D.A., eds., The Black Sea-Geology, chemistry, and biology: American Association of Petroleum Geologists Memoir 20, p. 183-199.

Ross, D.A., Degens, E.T., and Macllvaine, J., 1970, Black Sea-Recent sedimentary history: Science, v. 170, p. 163-165.

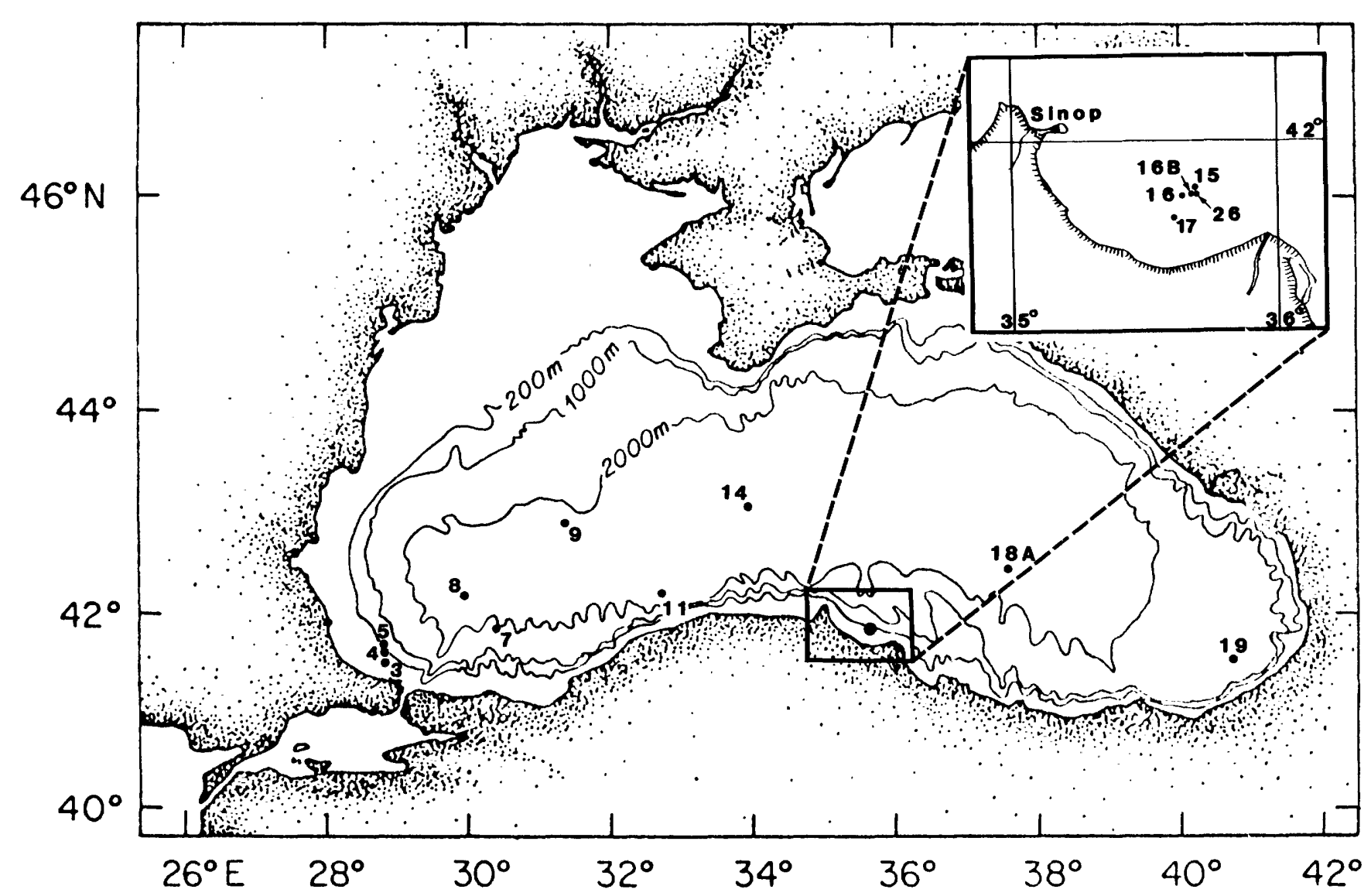

Figure 1. Box-coring stations of Leg 4 of the 1988 Black Sea Expedition (insert shows detailed map of the Bay of Sinop region). 


\title{
Organic Geochemical Studies of Metalliferous Parts of the Middle Proterozoic Nonesuch Formation of Northern Michigan
}

\author{
By Philip A. Meyers ${ }^{1}$, Eileen S. Ho ${ }^{1}$, and Jeffrey L. Mauk ${ }^{1}$
}

\begin{abstract}
Organic matter in metalliferous parts of the Nonesuch Formation of northern Michigan was characterized by isotopic, molecular, and spectrophotometric procedures and compared to organic matter in nonmetalliferous sections. Samples from the White Pine copper mine contain little organic carbon in comparison to samples from outside the mine area. Residual organic matter in mine samples is low in solvent-extractable matter and relatively aromatic in character, yet no difference in carbon isotopic contents is evident between kerogen isolated from metalliferous and nonmetalliferous rocks.
\end{abstract}

\section{INTRODUCTION}

The common association of metallic ore deposits and rocks enriched in organic carbon implies that organic matter was involved in formation of the mineralized rocks. A postulated role of the organic matter is as a reductant of metal-bearing solutions that have migrated through these rocks. Selective losses and alterations of the organic matter would accompany precipitation of minerals. Püttmann and others (1988) documented, for example, the loss of extractable aliphatic hydrocarbons and the sulfidization of aromatic hydrocarbons that evidently resulted from deposition of copper and silver ores in the Permian Kupferschiefer of Poland.

\section{THE NONESUCH FORMATION}

The Nonesuch Formation of northern Michigan was deposited under a freshwater lake created by rifting of the

\footnotetext{
${ }^{1}$ Department of Geological Sciences, University of Michigan, Ann Arbor, Michigan 48109-1063.
}

North American craton during Keweenawan time (ca. 1.1 $\mathrm{Ga}$ ) of the Middle Proterozoic Era. The formation ccntains sandstones, siltstones, shales, and carbonate laminites and has organic carbon contents as high as 3 weight percent. The lower part of the Nonesuch is organized into informal units called, in ascending order, the parting shale, the upper sandstone, and the upper shale (fig. 1). As summarized by Barghoorn and others (1965) and Imbus and others (1988), the section represents an evolution of the depositional setting from marginal lacustrine to deep lacustrine to fluvial lacustrine. Euxinic shales and siltstones form the maiority of the rock types, and their average thickness is $18 \mathrm{C} \mathrm{m}$.

Copper-rich solutions are believed to have migrated into the Nonesuch Formation where interaction with organic-carbon-rich rock layers precipitated copp?r-iron sulfide minerals and native copper and silver (Wiese, 1973; Kelly and Nishioka, 1985). Because copper-mineralized rocks are generally restricted to the base of the Nonesuch Formation and to the top of the underlying Copper Harbor Conglomerate, the migrating fluids are believed to have entered the Nonesuch Formation from below (White, 1971). Although the Nonesuch Formation is regionally extensive, copper-mineralized rocks reach ore grades only locally in the vicinity of the White Pine Mine (Ensign and others, 1968).

\section{SAMPLES AND PROCEDURES}

We obtained metalliferous rock samples from within the White Pine Mine from below, at, and above the contact between the Nonesuch Formation and the underlying Copper Harbor Conglomerate. The rock units sampled include the lower sandstone of the Copper Harbor and the domino shale of the parting shale and the thinly shale of the upper shale of the Nonesuch Formation (fig. 1). Active petroleum seeps are present locally in the mine (Eglinton 


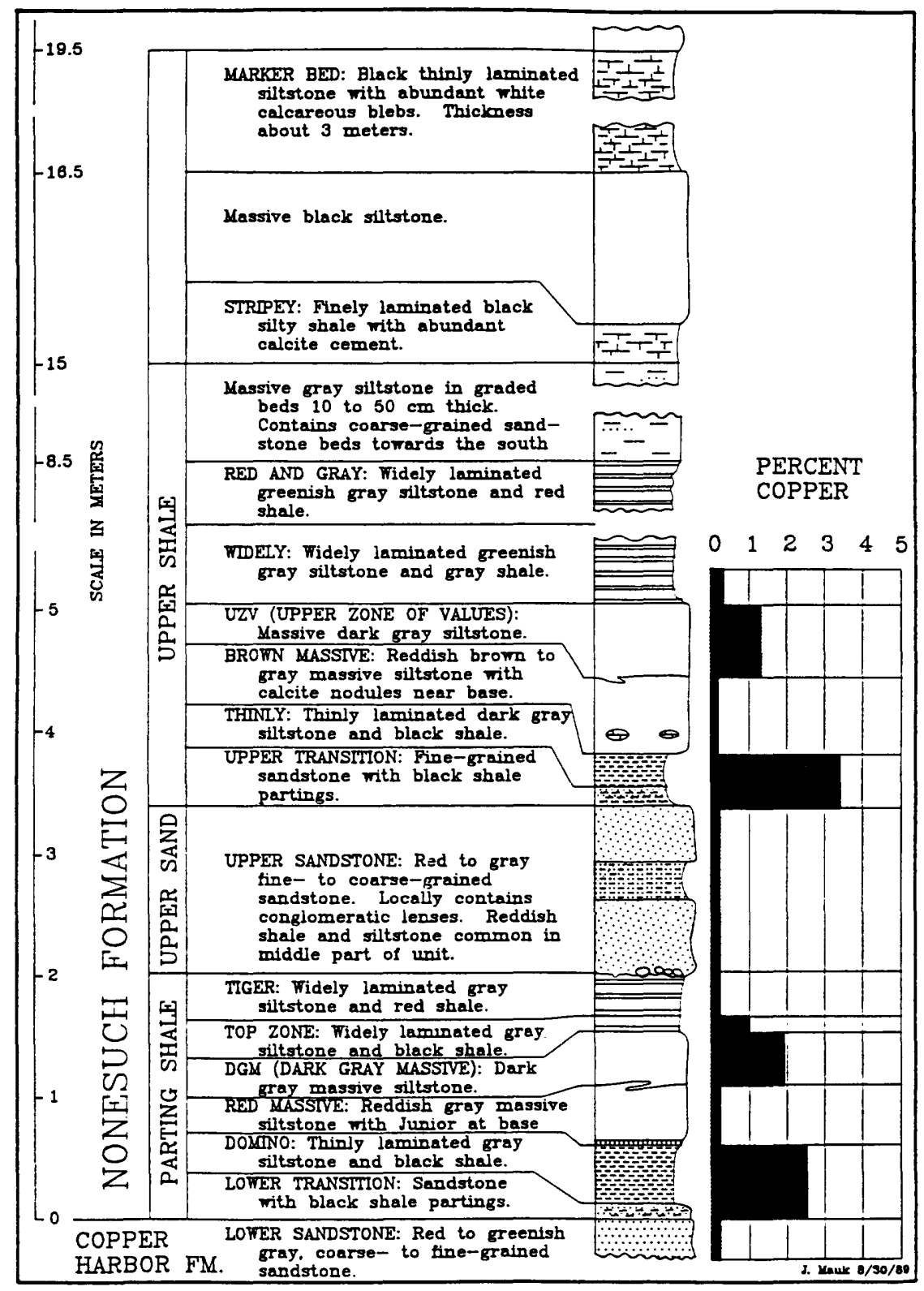

Figure 1. Stratigraphy of the upper part of the Copper Harbor Conglomerate and the Nonesuch Formation in the area of the White Pine Mine, northern Michigan.

and others, 1964; Barghoorn and others, 1965); our samples were selected to avoid these seeps.

Organic carbon contents were determined by removing carbonate minerals from dried and ground samples using $3 \mathrm{~N} \mathrm{HCl}$ and measuring the amount of residual carbon using a Hewlett-Packard 185B CHN analyzer. Lack of measurable amounts of nitrogen precluded determination of organic matter carbon/nitrogen values. Organic carbon stable isotope ratios were obtained from carbonate-free samples using a VG Micromass 602 mass spectrometer and are reported relative to the PDB standard. Rock-Eval analyses were done using a Delsi Nermag Rock-Eval II instrument.
Extractable matter was obtained from dried and ground samples by Soxhlet extraction using $\varepsilon$ mixture of toluene and methanol, $3 / 1$, and refluxing for 48 hours. Because so little matter was extracted from the samples, it was not fractionated prior to analysis. The total extracted material was analyzed using a Hewlett-Packard 5830 FID gas chromatograph equipped with a $20-\mathrm{m}$ SE- 54 capillary column and a splitless injection system.

To isolate kerogen from the samples, rock's were first ground and then extracted with organic solvents to remove lipid materials. Carbonate minerals were removed by dissolution with concentrated $\mathrm{HCl}$, followed by rinsing with distilled water. Concentrated HF was then added at room 
Table 1. Carbon isotope ratios, organic carbon concentrations, and concentrations of total extractable material in samples of the Nonesuch Formation from the White Pine Mine

[nd indicates not determined]

\begin{tabular}{|c|c|c|c|c|}
\hline Sample & & $\begin{array}{c}\delta^{13} \mathrm{C} \\
(\% \text { PDB })\end{array}$ & $\begin{array}{c}\% \mathrm{C}_{\text {org }} \\
\text { (weight percent) }\end{array}$ & $\begin{array}{c}\text { Total extract } \\
\text { (ppm) }\end{array}$ \\
\hline WP-5 & Thinly & shale.............................nd & 0.21 & nd \\
\hline WP-6 & Thinly & shale.......................... -31.32 & 0.47 & 49.6 \\
\hline WP-7 & Thinly & shale........................ -31.82 & 0.16 & 26.7 \\
\hline WP-9 & Thinly & shale........................... -33.45 & 0.25 & 24.5 \\
\hline WP-10 & Thinly & shale........................ -33.58 & 0.19 & 18.7 \\
\hline WPM88-024 & Thinly & shale.......................... -33.50 & nd & nd \\
\hline WPM88-025 & Thinly & 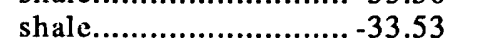 & nd & nd \\
\hline WP-3 & Domino & 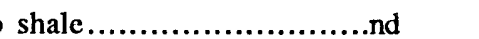 & 0.08 & nd \\
\hline WP-4 & Domino & shale $\ldots \ldots \ldots \ldots \ldots \ldots \ldots \ldots$ nd & 0.35 & nd \\
\hline WP-11 & Domino & 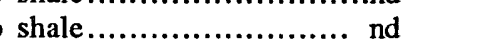 & 0.07 & nd \\
\hline WP-8 & Lower & sandstone................... -23.95 & 0.35 & 11.3 \\
\hline WPM88-190 & Lower & sandstone..................... -33.35 & nd & nd \\
\hline WPM88-192 & Lower & sandstone...................... -33.41 & nd & nd \\
\hline
\end{tabular}

temperature to remove silicate minerals. This step was repeated several times until no more mineral material remained. If fluoride minerals formed during the $\mathrm{HF}$ treatment, additional $\mathrm{HCl}$ was added to dissolve them so that distilled water rinses might remove the neoformed fluorides from the kerogen plus chalcocite residue. During kerogen isolation from samples of the lower sandstone, floating dark-colored matter was obtained after the rock had been dissolved. This was collected and analyzed separately from the bulk kerogen.

After the insoluble residue from the rock dissolution was oven-dried, it was analyzed using Fourier transform infrared (FTIR) spectroscopy. This analysis was achieved by forming pressed pellets from finely ground mixtures of $\mathrm{KBr}$ and the kerogen isolates and scanning the pellets from $4,000 \mathrm{~cm}^{-1}$ to $400 \mathrm{~cm}^{-1}$, using a Nicolet 5-DX spectrometer in transmittance mode.

\section{RESULTS AND DISCUSSION}

Rock samples from metalliferous rocks in the White Pine Mine contain little organic matter (table 1), whereas nonmetalliferous parts of the Nonesuch Formation contain as much as 2 percent organic carbon (Imbus and others, 1988). The samples from the domino stratum of the parting shale, near the base of the metalliferous zone, have an average organic carbon content of 0.17 percent, and the samples from the thinly stratum of the upper shale have an average content of 0.26 percent. Concentrations of total solvent-extractable material in the lower sandstone samples $(11 \mathrm{ppm})$ and in the thinly shale samples (average $30 \mathrm{ppm}$ ) are low for petroleum source rocks (Tissot and Welte, 1984, p. 177). In contrast, extractions from nonmetalliferous core and surface outcrop samples indicate that parts of the Nonesuch Formation which overlie the ore-bearing strata are rich in hydrocarbons (Imbus and others, 1988; Hieshima and others, 1989).

Organic carbon in kerogen isolated from bcth the thinly shale and the lower sandstone is isotopically' light, having $\delta^{13} \mathrm{C}$ values between $-31 \%$ and $-34 \%$ (PDB). These values are similar to those reported by Barghoorn and others (1965) for kerogen from a metalliferous sample and by Imbus and others (1988) for nonmetalliferous samples. The mineralization process and postulated oxidation of crganic carbon evidently did not cause an isotopic shift. One sample of the lower sandstone, WP-8, gave a markedly 1 savier isotope ratio of $-23.95 \%$. This sample may have contained some residual carbonate carbon, inasmuch as its measured "organic" carbon value of 0.35 percent is high for a sandstone having little extractable matter, and Bar shoorn and others (1965) showed that carbonate carbon in the Nonesuch Formation has $\delta^{13} \mathrm{C}$ values of about $-4 \%$ (PDB).

Comparison of chromatograms of the total extractable material from metalliferous rocks and of the extractable aliphatic hydrocarbon fraction from samples of noncupriferous rocks collected away from the mine area reveals important differences (fig. 2). Although some of the peaks in the total extract trace may not be hydrocarbons these differences are significant. Whereas the noncupriferous extract distribution is dominated by a range of $n$-alkares, the pattern for the metalliferous sample shows few of these hydrocarbons. Instead, the distribution resembles those shown for hydrothermally altered basal rocks fro $m$ the Kupferschiefer (Pttmann and others, 1988), in which oxidation of aliphatic organic matter by mineral-1 saring fluids is postulated.

Rock-Eval pyrolyses of metalliferous rock s $\gg$ mples are generally not informative because the rocks conta $\eta$ little organic matter. Two samples, however, one from the parting shale and one from the upper shale, gave similar hydrogen index and oxygen index values of $70 \mathrm{mgHC} / \mathrm{gTC} ?$ and 


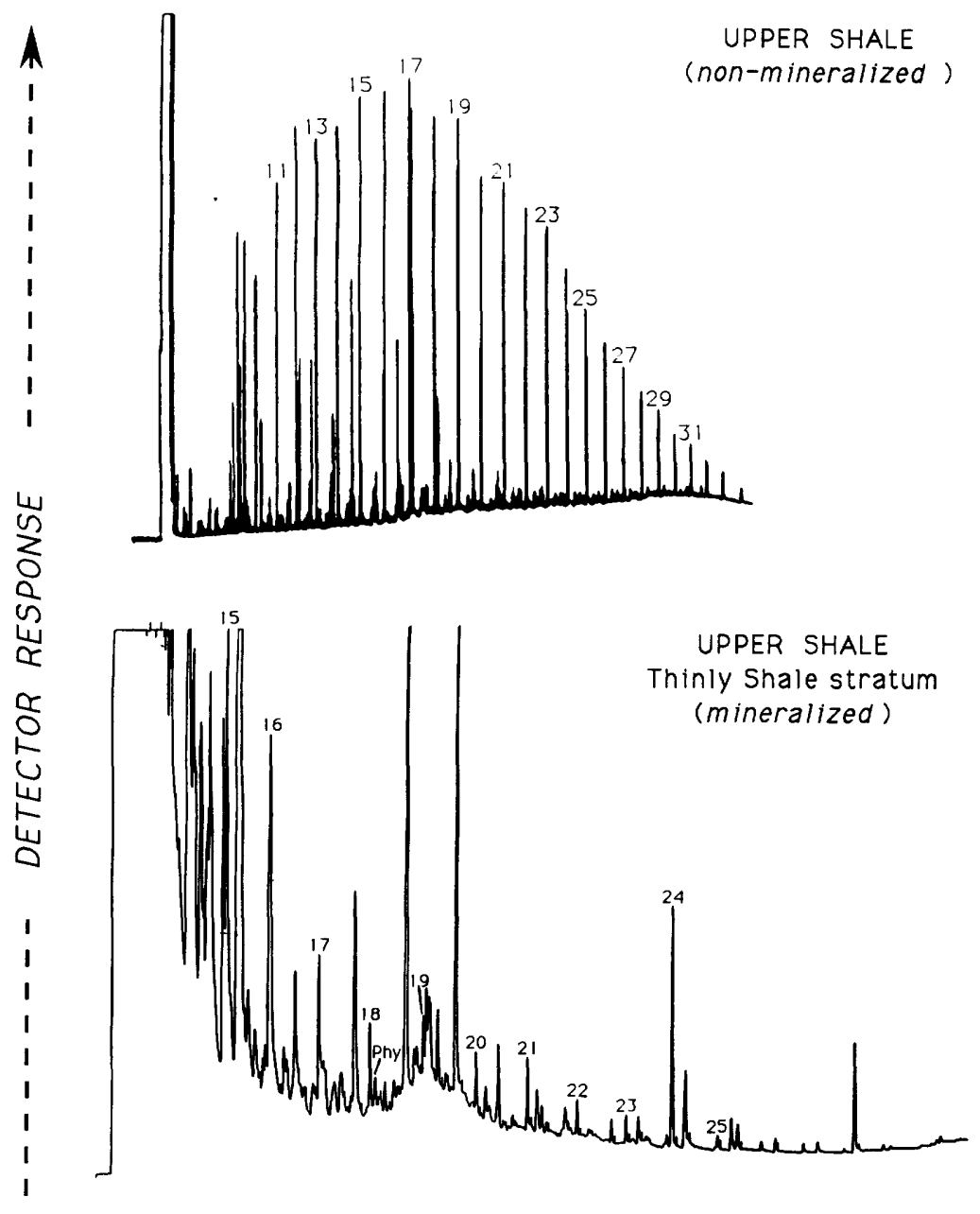

\section{RETENTION TIME}

Figure 2. Capillary gas chromatographs of the extractable hydrocarbons from a nonmetalliferous section of the upper shale (top) and of the total extractable material from a metalliferous section of the thinly shale (bottom). The upper shale chromatogram was kindly provided by L. Pratt, Indiana University.

40-50 $\mathrm{mgCO}_{2} / \mathrm{gTOC}$, respectively ( $\mathrm{HC}=$ hydrocarbons, TOC=total organic carbon). These indices are typical for thermally degraded algal organic matter. $T_{\max }$ values of $450-460{ }^{\circ} \mathrm{C}$ suggest, however, that the rocks were heated not much higher than the approximately $100^{\circ} \mathrm{C}$ indicated by sulfide minerals (Brown, 1971) and fluid inclusion studies (Nishioka, 1983). The great age of these strata, not their thermal history, evidently is the major contributor to the moderate thermal maturity of the organic matter.

The FTIR spectra of kerogen isolated from samples of the thinly shale and the lower sandstone show distinctive patterns for the two strata (fig. 3). Within each rock type, the FTIR patterns of different samples are similar, except that the spectra of the floatable kerogenous material isolated from the lower sandstone during mineral dissolution differ from those of the bulk kerogen.
The infrared spectral band at $1,644 \mathrm{~cm}^{-1}$, most likely corresponding to aromatic $\mathrm{C}=\mathrm{C}$ bond st "etching, is prominent in kerogen spectra from both the thinly shale and the lower sandstone. The spectral bands between wavenumbers $2,965 \mathrm{~cm}^{-1}$ and $2,850 \mathrm{~cm}^{-1}$, corresponding to aliphatic $\mathrm{C}-\mathrm{H}$ bond stretching of methylene and methy! groups, are significant only in the spectra of kerogen from the lower sandstone samples. These data imply that the brlk kerogens in these two strata have considerable aromat c character, with the kerogen from the lower sandstone being more aliphatic in character.

The infrared spectra of the floatable low 9 sandstone kerogens are characterized by strong aliphatic $\mathrm{C}-\mathrm{H}$ bands and an absent or notably weaker aromatic $\mathrm{C}=\mathrm{C}$. band. The highly aliphatic character of this material, tc gether with petrographic evidence of pore-filling organic matter in the 


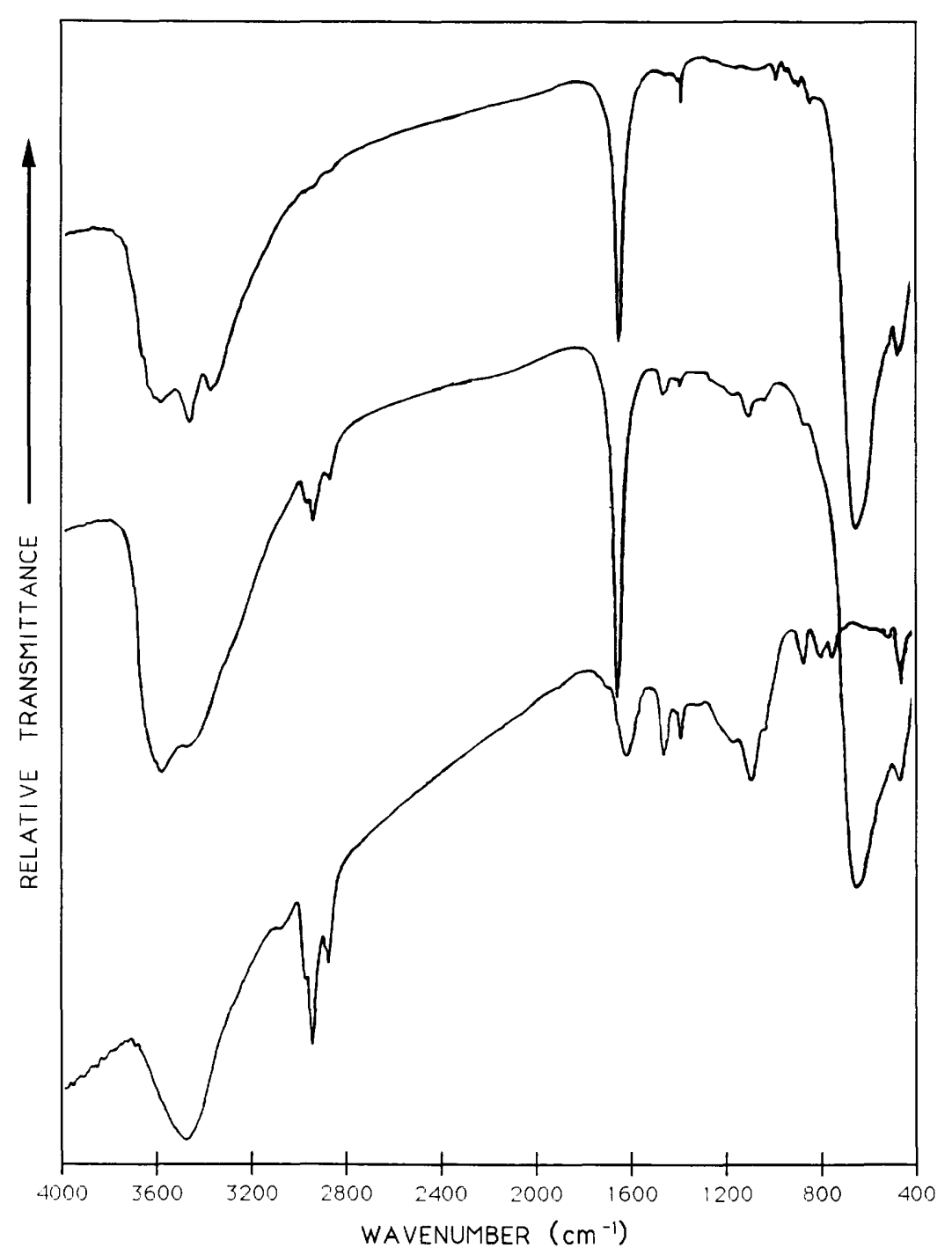

Figure 3. Fourier transform infrared spectra of kerogen isolated from the thinly shale (top) and the lower sandstone (middle) and of floatable organic matter released by dissolution of the lower sandstone during kerogen isolation (bottom).

lower sandstone strata, suggests that the floatable material may be the residue of petroleum that migrated through this sandstone layer.

None of these spectra displays evidence of $\mathrm{C}=\mathrm{O}$ bond stretching, and thus the kerogen of these samples probably contains few carbonyl-oxygen-containing functional groups. The broad bands centered around $3,450 \mathrm{~cm}^{-1}$ in all samples may contain significant information about the presence or absence of functional groups, but it is masked by the unavoidable infrared absorption by water in this part of the spectrum.

\section{SUMMARY}

Characterization of organic matter from metalliferous and nonmetalliferous parts of the Nonesuch Formation of northern Michigan provides inferences about the role of organic matter in ore formation. These characterizat ons are summarized in table 2. Organic matter in the White Pine copper deposits probably has been degraded relative to noncupriferous parts of the formation. The lower concentrations of organic carbon and of solvent-ext"actable material in the mineralized samples are consistent with the hypothesis that oxidation of organic matter occurrec during deposition of copper from metal-bearing solutions. The absence of a significant contribution of $n$-alkanes to the total extractable material and the aromatization of keriogen in mineralized rocks are additional support for this hypothesis. Further investigations of how the amounts and types of organic matter relate to the abundance and occurronce of copper-mineralized rocks are needed to ascertain whether organic matter was an active participant in the redox precipitation of the ores in these rocks. 
Table 2. Summary comparison of organic-matter characteristics of metalliferous rocks from the Nonesuch Formation in the White Pine Mine and of nonmetalliferous rocks from outside the mine area

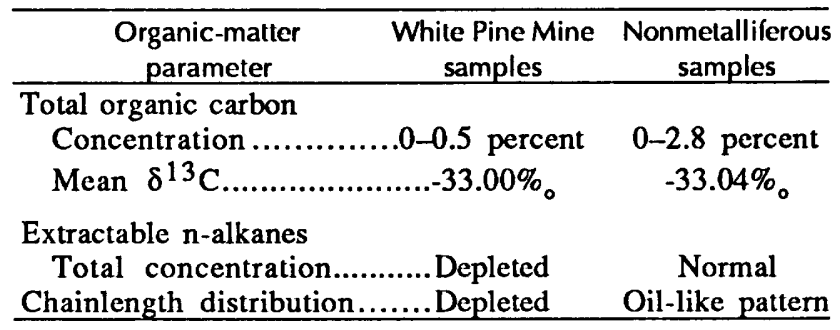

Acknowledgments.-We thank the White Pine Copper Company for allowing access to its property. Field work at White Pine was supported by a grant from Amoco Oil Company. We are grateful to W.C. Kelly for sharing with us his knowledge and understandings of the geologic setting. Rock-Eval analyses were kindly provided by J.G. Palacas, and L. Pratt shared her unpublished extractable organic matter information with us. This work has been supported, in part, by a grant from the U.S. National Science Foundation (EAR-8707353).

\section{REFERENCES CITED}

Barghoorn, E.S., Meinschein, W.G., and Schopf, J.W., 1965, Paleobiology of a Precambrian shale: Science, v. 148, p. $461-472$.

Brown, A.C., 1971, Zoning in the White Pine copper deposit, Ontonagon County, Michigan: Economic Geology, v. 66, p. 543-573.
Eglinton, G., Scott, P.M., Belsky, T., Burlingam^, A.L., and Calvin, M., 1964, Hydrocarbons of biological origin from a one-billion-year-old sediment: Science, v. 145, p. 263-264.

Ensign, C.O., Jr., White, W.S., Wright, J.C., Patrick, J.L., Leone, R.J., Hathaway, D.J., Trammell, J.W., Fritts, J.J., and Wright, T.L., 1968, Copper deposits in the Nonesuch Shale, White Pine, Michigan, in Ridge, J.D., ed., Ore deposits of the United States 1933-1967 (Graton-Salss Volume): American Institute of Mining, Metallurgy, and Petroleum Engineering, v. 1, p. 459-488.

Hieshima, G.B., Zaback, D.A., and Pratt, L.M., 1989, Petroleum potential of Precambrian Nonesuch Formation [abs.]: American Association of Petroleum Geologists Bulletin, v. 73, p. 363.

Imbus, S.W., Engel, M.H., Elmore, R.D., and Zumberge, J.E., 1988, The origin, distribution and hydrocarbon generation potential of organic-rich facies in the Nonesuch Formation, Central North American Rift System-A rerional study: Organic Geochemistry, v. 13, p. 207-219.

Kelly, W.C., and Nishioka, G.K., 1985, Precambrian oil inclusions in late veins and the role of hydrocarbons in copper mineralization at White Pine, Michigan: Geslogy, v. 13, p. 334-337.

Nishioka, G.K., 1983, Origin of late veins in the Whit Pine copper deposit, northern Michigan: Ann Arbor, University of Michigan, M.S. thesis, 51 p.

Ptmann, W., Hagemann, H.W., Merz, C., and Speczik, S., 1988, Influences of organic material on mineralizat ion processes in the Permian Kupferschiefer Formation, Poland: Organic Geochemistry, v. 13, p. 357-363.

Tissot, B.P., and Welte, D.H., 1984, Petroleum formation and occurrence (2nd ed.): Berlin, Springer Verlag, p. 177.

White, W.S., 1971, A paleohydrologic model for the mineralization of the White Pine copper depc sit, northern Michigan: Economic Geology, v. 66, p. 1-13.

Wiese, R.G., Jr., 1973, Mineralogy and geochernistry of the Parting Shale, White Pine, Michigan: Economic Geology, v. 68 , p. $317-331$. 


\title{
Organic Geochemical and Petrological Investigations of a Natural Reactor and Its Environs at Oklo, Gabon- A Preliminary Report
}

\author{
By Bartholomew Nagy ${ }^{1}$, Joel S. Leventhal ${ }^{2}$, and F. Gauthier-Lafaye ${ }^{3}$
}

Parts of the uraniferous ore deposits in the Early Proterozoic Francevillian Series at Oklo, Gabon, went critical at about $2 \mathrm{Ga}$ and produced a number of natural fission reactors. The main uranium ore zone, which was only minimally metamorphosed, contains $0.1-1.0$ percent uranium and is associated with migrated organic matter (bitumen) (Gauthier-Lafaye, 1986). High-grade ores contain $20-60$ percent $U$ and also contain organic matter. The fission reaction originated in the high-grade ores where water acted as the moderator; the reactors shut down when the contained water was expelled (Naudet, 1978). This expulsion of high-temperature water under high pressure caused extensive hydrofracturing (similar to the petroleum industry's hydro-frac process) in the reactor zone, in the surrounding ore deposit, and in some adjacent rocks. Organic liquids derived from syngenetic kerogen by the action of water at elevated temperatures (through a process apparently analogous to hydrous pyrolysis) were injected into the fractures. Aqueous solutions were also injected into the fractures. Migration of the organic and the inorganic liquids into the fractures occurred at least twice during the early geological history of the uranium ore deposits and the surrounding sedimentary rocks. The new work reported here is the study of catagenesis-metagenesis, migration of organic matter, and mobilization of uranium daughter and fission products. Mobilization of uraniferous kerogen has been reported before; for example, at Cluff Lake, Canada (Leventhal and others, 1987), and Elliot Lake, Canada (Nagy, 1989).

\footnotetext{
${ }^{1}$ Laboratory of Organic Geochemistry, Department of Geosciences, University of Arizona, Tucson, Arizona 85721.

${ }^{2}$ U.S. Geological Survey, Denver Federal Center, Box 25046, MS 973, Denver, Colorado 80225.

${ }^{3}$ Centre National de la Recherche Scientifique, Centre de Sédimentologie et de Géochimie de la Surface, 1, Rue Blessig, 67084 Strasbourg Cedex, France.
}

The organic matter in a suite of samples (designated as KP3, Cro.336, Boy.33.FC, Boy.33.5, FB black shale, and $\mathrm{LN}-12$; table 1) from Gabon was characterized in an attempt to define the possible retentivity of uranium and its fission and daughter products by organic matter at and various distances from the natural reactors. These six samples are organic matter rich, containing 10-55 percent organic carbon. One (KP3) is from the natural f'ssion reactor number 9 at Oklo, one (Cro.336) is from the northern part of the Oklo deposit, two (Boy.33.FC and Boy.33.5) are from the nearby sandstone of the Boyindzi uranium deposit that did not go critical, and twc (FB black shale and $\mathrm{LN}-12$ ) are not part of the deposit and are remote (50 and $25 \mathrm{~km}$, respectively) from Oklo. Scanning electron microscopy (SEM) and semiquantitative energy-dispersive spectrometry (EDS) of the $\mathrm{Ll}^{\top}$ and FB samples (figs. 1 and 2) revealed that they are, respectively, a bitumen having markedly conchoidal fra:tures and a kerogenous siltstone. Subrounded and subangular quartz, pyrite, and clay minerals are the major components in the FB black shale. The original mineral texture of the shale, which developed during deposition, is remarkably well preserved and was only minimally altered during subsequent diagenesis. Some of the round o* subrounded pyrite grains have hollow interiors. Rock-Eval pyrolysis results for all these samples are typical of overmature organic matter and include very low hydrogen index $(\mathrm{HI})$ values of $2-80 \mathrm{~g}$ hydrocarbons per gram total organic carbon and high $T_{\max }$ of $472-604^{\circ} \mathrm{C}$. The oxygen index (OI) values are 4-49. Surprisingly, all four of the uranium-rich samples have high OI values. Three of them have the high $\mathrm{HI}$ values and have the lowest $\mathrm{T}_{\max }$ values. Stepwise pyrolysis-gas chromatography showed mainly gases for the Oklo uranium-rich samples (Cro.336, KP3). Organic matter from samples of the Boyindzi uraniun deposit (FC was an organic-rich separate of the bulk 
sample) gave, in addition to gases, a suite of aromatic pyrolysis products containing as many as 12 carbon atoms. The samples away from the deposit showed mainly gases and some alkyl-substituted benzenes. Separate pyrolysisgas chromatography with coupled mass spectrometry showed, however, that all the samples have fairly similarmolecular signatures (but with varying abundances) of mainly alkyl-substituted, one and fused-ring aromatics, elemental sulfur and light gases such as carbon disulfide. Only the remote samples showed traces of $n$-alkanes. There were some differences between samples. In particular, the remote sample $\mathrm{FB}$ showed only $\mathrm{CS}_{2}$, benzene, toluene and xylenes, and perhaps indene, whereas, the sample from the reactor core (KP3) and both samples from Boyindzi (Boy.33.5 and 33.FC) gave more diverse pyrolysis products that also included naphthalene and mono- and dimethyl-substituted naphthalenes. The much lower hydrogen index of sample Cro.336 may account for its lack of fused-ring pyrolysis products. To explain these results we propose that, in addition to their syngenetic kerogen, the uranium-rich samples may contain two types of bitumen that were generated and migrated during diagenesis and the operation of the natural reactor and that subsequently were polymerized to a solid, in part by radiation damage. Laser Raman microspectroscopy of the samples gave two broad peaks at around $1,590-1,600$ and $1,330-1,360$ $\mathrm{cm}^{-1}$. The two remote samples (LN and FB) showed the best peak near $1,600 \mathrm{~cm}^{-1}$ (smallest width at half-height), probably because their very low uranium contents have little effect on disrupting the crystallinity. The two broad peaks, rather than a sharp one at $1,582 \mathrm{~cm}^{-1}$, indicate that at least part of the organic matter is now cryptocrystalline graphite that has not yet matured to graphite of crystal size as large as 1 micrometer. Preliminary ICP-mass spectrometric studies of kerogen particles that have flat and globulelike shapes in the Boy.33.FC sample $(5 \mathrm{~km}$ from Oklo) and of the kerogenous, whole-rock FB sample (50 $\mathrm{km}$ southeast of Oklo) revealed only trace amounts of ${ }^{235} \mathrm{U},{ }^{238} \mathrm{U},{ }^{206} \mathrm{~Pb},{ }^{207} \mathrm{~Pb}$, and ${ }^{208} \mathrm{~Pb}$ in the latter but considerable abundances of these isotopes in the former. Our preliminary suggestion is that both fluid migration and organic matter may have affected the redistribution of uranium and other isotopes during syngenetic and epigenetic events.
Table 1. Summary of sample descriptions

\begin{tabular}{|c|c|}
\hline Sample & Description \\
\hline KP3 .... & $\begin{array}{l}\text {. Part of the Natural Fission Reactor No. } 9 . \\
\text { Sandstone has high uranium and organic- } \\
\text { matter contents. Organic matter is black; } \\
\text { majority of minerals are white ant have an } \\
\text { ill-defined, pseudoflaky, fibrous } \\
\text { morphology. }\end{array}$ \\
\hline Cro.336.. & $\begin{array}{l}\text { Sample from the northern part of the Oklo } \\
\text { uranium deposit. Not part of Reactor No. } 9 \text {. } \\
\text { Sandstone has high uranium and organic- } \\
\text { matter contents. Contains disseminated } \\
\text { black organic particles and a 5-n-m-thick } \\
\text { black layer of organic matter. }\end{array}$ \\
\hline Boy.33.F & $\begin{array}{l}.5 \mathrm{~km} \text { from Oklo, at the Boyindzi ore deposit. } \\
\text { Uranium-rich sandstone contains abundant, } \\
\text { black organic globules more than } 14 \mathrm{~mm} \text { in } \\
\text { diameter. }\end{array}$ \\
\hline Boy.33.5. & $\begin{array}{l}.5 \mathrm{~km} \text { from Oklo, at the Boyindzi ore deposit. } \\
\text { Sandstone has lower uranium cortent than } \\
\text { Boy.33.FC. Contains organic globules } 2-5 \\
\text { mm in diameter. Euhedral quartz, yellow } \\
\text { minerals, and white veins are visible. }\end{array}$ \\
\hline LN-12.... & $\begin{array}{l}.25 \mathrm{~km} \text { from Oklo, in the district of Mounana. } \\
\text { Black, shiny, and brittle organic matter } \\
\text { shows conchoidal fractures and contains no } \\
\text { visible mincral inclusions. Probrbly a vein } \\
\text { traversed by the drill core. }\end{array}$ \\
\hline $\begin{array}{r}\text { FB black } \\
\text { shale... }\end{array}$ & $\begin{array}{l}.50 \mathrm{~km} \text { from Oklo, near Franceville. } \\
\text { Kerogen-rich siltstone contains cuartz, clay } \\
\text { minerals, and pyrite. }\end{array}$ \\
\hline
\end{tabular}

\section{REFERENCES CITED}

Gauthier-Lafaye, F., 1986, Les gisements d'uranium du Gabon et les réacteurs d'Oklo, Modele métallogéniqu ıe de gites a fortes teneurs du Protérozoique inférieur: Mérmoire Sciences Géologiques, v. 78, p. 206.

Leventhal, J.S., Grauch, R.I., Threlkeld, C.N., Lichte, F.E., and Harper, C.T., 1987, Unusual organic matter a-sociated with uranium from the Claude deposit, Cluff Lake, Canada: Economic Geology, v. 82, p. 1169-1176.

Nagy, B., 1989, Some evolutionary pathways of metalliferous black shales and other fine-grained sediments-Uraniferous kerogens at Witwatersrand, South Africa, Elliot Lake, Canada, and Oklo, Gabon, in Grauch, R.I., and Leventhal, J.S., eds., Metalliferous black shales and related ore deposits-Program and abstracts: U.S. Geological Survey Circular 1037, p. 5-7.

Naudet, R., 1978, Etude paramétrique de la criticité des réacteurs naturels, in Natural fission reactors: International Atomic Energy Agency, Vienna, p. 589-600. 


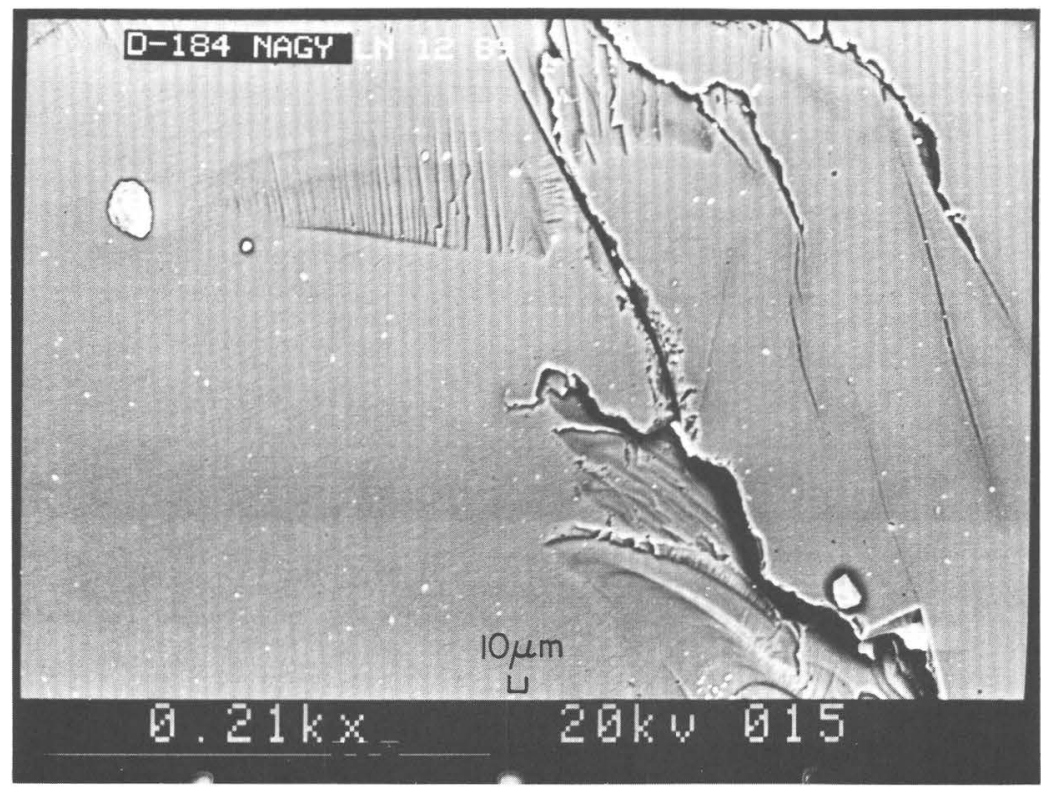

Figure 1. Backscattered scanning electron micrograph of sample LN-12 showing conchoidal fractures in the brittle organic matter. Sample is from a drill core and is probably part of a vein. Photograph from D.H. Krinsley, Department of Geology, Arizona State University, Tempe, Arizona.

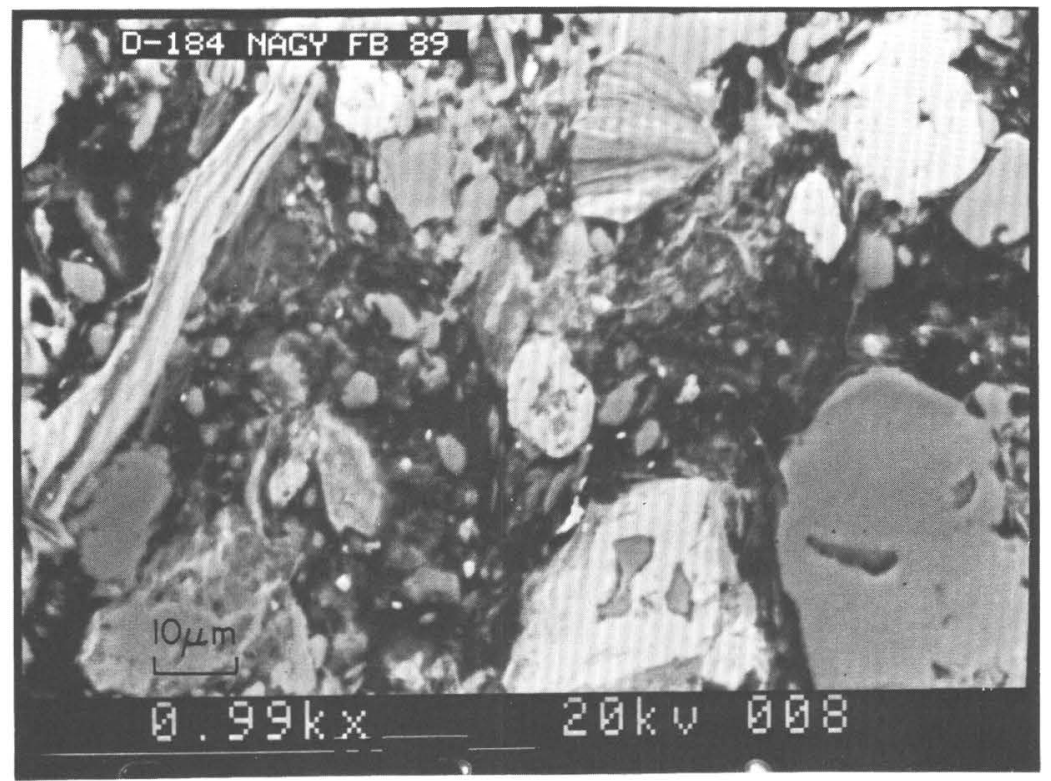

Figure 2. Backscattered scanning electron micrograph of the FB black shale sample. Quartz is gray in color, pyrite is white, and kerogen is black. Note clay minerals at the upper left part of the electron micrograph. Photograph from D.H. Krinsley, Department of Geology, Arizona State University, Tempe, Arizona. 


\title{
Midcontinent Virgilian (Upper Pennsylvanian) Black Shales in Eastern Kansas
}

\author{
By R.B. Schultz ${ }^{1}$ and J.B. Maynard ${ }^{1}$
}

\begin{abstract}
Black shales, commonly metal rich, are distinct members of repetitive sequences of strata, referred to as megacyclothems, in the Midcontinent Virgilian. Four black shale members are present in the Shawnee Group and one black shale member is present in the Wabaunsee Group in eastern Kansas. Based on geochemical parameters including pyrite iron, pyrite sulfur content, acid-extractable iron content, percent total sulfur, and degree of pyritization (DOP), two types of black shales are present in the eastern Kansas Virgilian.

Heebner-type black shales include the prototype Heebner Shale Member of the Oread Limestone, Queen Hill Shale Member of the Lecomption Limestone, and Larsh Shale and Burroak Shale Members of the Deer Creek Limestone. Shanghai Creek-type black shales include the prototype Shanghai Creek Shale Member of the Howard Limestone and Holt Shale Member of the Topeka Limestone.

Geochemically, Heebner-type black shales contain more total sulfur (mean $=0.75$ percent) than the Shanghai Creek-type (mean $=0.10$ percent). The degree of pyritization is greater in the Heebner-type units (0.55) than in the Shanghai Creek-type (0.15). Additionally, Heebner-type black shales contain more acid-extractable iron.

Previously proposed black shale categories can also be related to depositional setting. Using $\mathrm{DOP}=0.45$ as a boundary between aerobic and restricted conditions and $\mathrm{DOP}=0.75$ as the distinction between restricted and inhospitable conditions, Heebner-type black shales are interpreted to have formed under restricted conditions and Shanghai Creek-type black shales under aerobic conditions.
\end{abstract}

\section{INTRODUCTION}

Upper Pennsylvanian black shales of the Midcontinent, which are commonly metalliferous, are present in carbonate-dominated Virgilian Series cyclic sequences

\footnotetext{
${ }^{1}$ University of Cincinnati, Department of Geology, Cincinnati, Ohio 45221-0013.
}

(fig. 1). These black shale units can be traced many miles in outcrops and in subsurface cores (Merriam, 1963). Characterized by prominent phosphate nodule development near the base of the unit, the black shales contain quartz, feldspars, calcite, dolomite, hematite, chlorite, kaolinite, illite, and various mixed-layer assemblages in various percentages (Schultz, 1987). Mixed terrestrial and marine organic matter make up as much as 30 percent of the units (Coveney and Glascock, 1989).

Stratigraphically, the black shales make up part of the most stable and recurring elements of cyclic sequences and represent the transgressive phase of development. Heckel (1977) offered a model for deposition of the black shales that envisions water becoming deep enough to develop a thermocline strong enough to prevent bottom oxygenation by wind-driven vertical circulation. Heckel's model for black shale deposition obviates the difficulty of explaining, in shallow tropical water, the combination of nonskeletal phosphate production and widespread uniformity of a quiet anoxic environment between two marine limestone units. A useful parameter in the discussion of black shale bottom conditions is the degree of pyritization (DOP), which has been advocated as a paleoenvironmental indicator of bottom-water oxygenation (Raiswell and others, 1988). The utilization of DOP forms the basis for this study of the bottom-water conditions of Upper Pennsylvanian black shales of the Midcontinent.

\section{Geologic Setting}

Throughout the Late Pennsylvanian, Kansas was covered by a shallow, subequatorial, epeiric sea (Heckel, 1972). Sediment was deposited in broad north-trending synclinal structures (Cubitt, 1975). Local and external tectonic events affected the sedimentary succession and provided an influx of sediment. Structurally high areas (fig. 2) limited the areal extent of the epeiric sea and included the Amarillo, Arbuckle, and Wichita uplifts to the south, the Ancestral Rockies to the west, and the Ozark dome to the east (Merriam, 1986). 


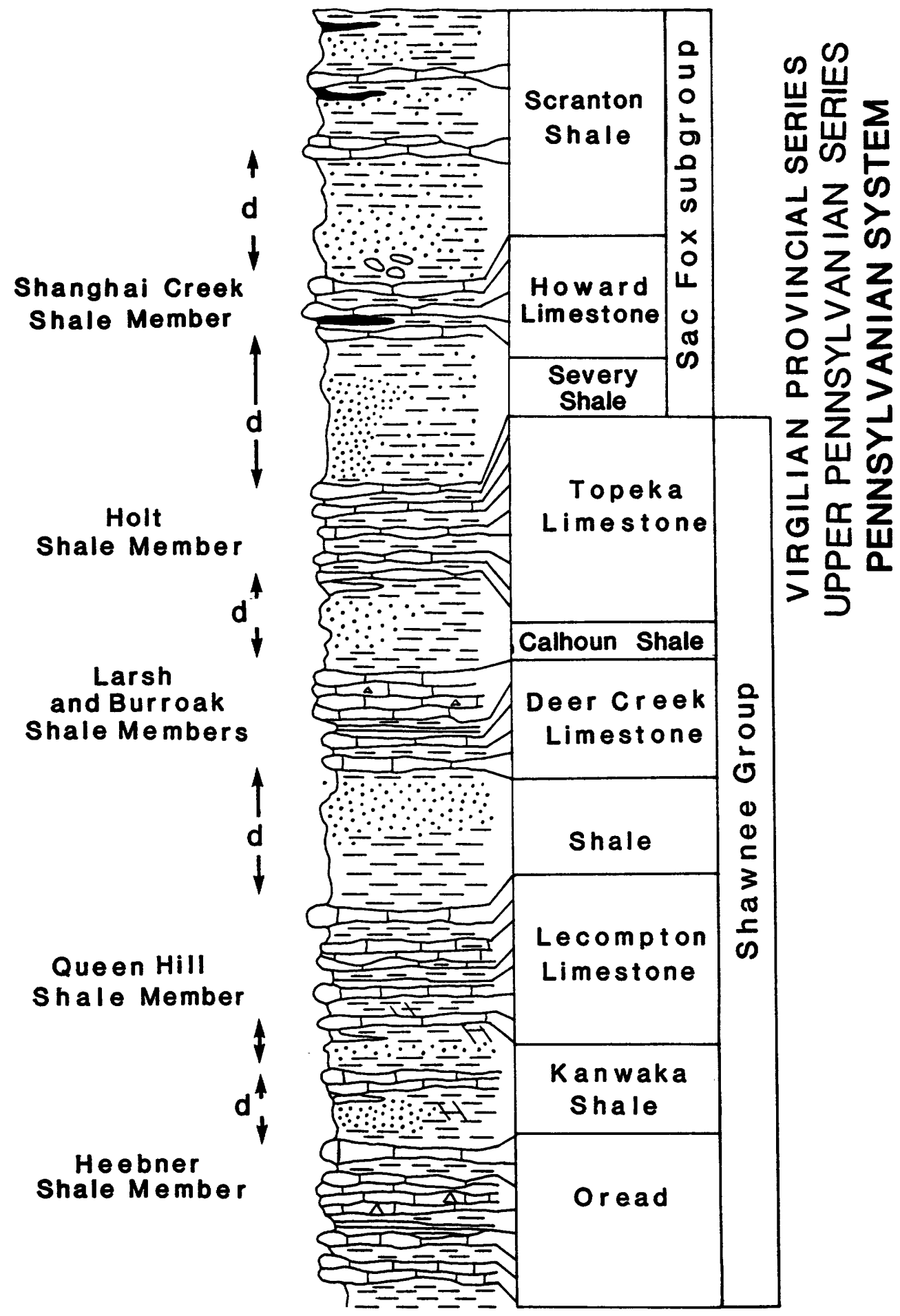

Figure 1. Generalized stratigraphic column of Virgilian rocks in Kansas. Black shale members are depicted on the left; $d$ denotes deltaic complex. Modified from Zeller (1968).

The Ancestral Rockies developed in response to orogenic fluctuations during the Late Devonian to Early Pennsylvanian (Cubitt, 1975). Clastic sediments were shed into adjacent basins during the Late Pennsylvanian (Cubitt, 1975). The Amarillo, Arbuckle, and Wichita uplifts, structurally associated with the Ouachita Mountains, may represent a continent-arc collision (Walper and Fowett, 1973) that occurred early during the subsequent opening of the proto-Atlantic Ocean (Cubitt, 1975). Erosion of Amarillo, Arbuckle, and Wichita Mountain chains during the Pennsylvanian produced clastic materials that were deposited in the vicinity of the Kansas sea. The Ozarl dome 


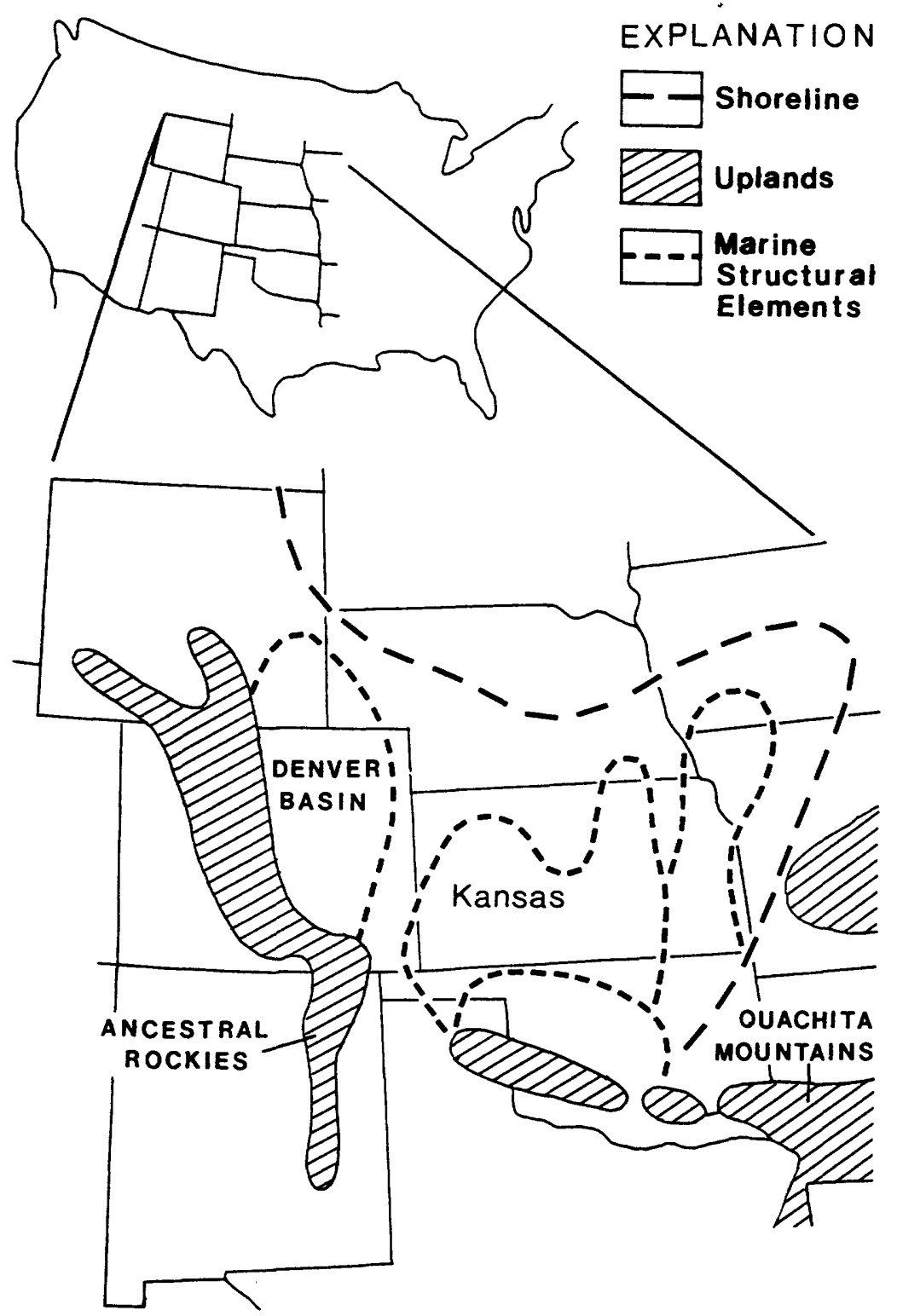

Figure 2. Tectonic features of the U.S. Midcontinent during Virgilian time. Modified from Cubitt (1979).

of east-central Missouri was a complex uplifted block of Precambrian crystalline igneous and Paleozoic sedimentary rocks. Channel sandstone deposits in the eastern Kansas Virgilian reflect the mineralogy of the Ozark region and are composed primarily of clay and silt (Cubitt, 1975).

Thus, it is postulated that during the Late Pennsylvanian in eastern Kansas, the rise of the Ouachita Mountains resulted in deposition of a thick clastic sequence, and during rapid uplifts clastic wedges built onto the shelf region of Kansas. Sedimentary deposits formed in the Kansas epeiric sea during the Virgilian consist of limestone alternating with thin, calcareous marine shales (gray marine shales and black shales) (Heckel, 1972). These mainly marine packages are interlayed with thick clastic units deposited from deltaic complexes from the Ouachita region and the lowlands north and east of Kansas (Heckel, 1972). Figure 1 depicts the shale and limestone sequences.

Shaw (1964) proposed that such epeiric seas rarely are deeper than $800 \mathrm{~m}$ and may have only been $130 \mathrm{~m}$ deep. Slopes would have been less than $1 \mathrm{~m}$ per kilometer at the time of deposition. The epeiric sea was subjected to global changes in sea level (Vail and others, 1977), and minor fluctuations of sea level were superimposed on the overall sea level trend. According to Wanless (1972), at least 25 separate transgressions and regressions are recignized in the Virgilian. Pennsylvanian paleogeography, based on the presence of coals, evaporites, and dune-sand deposits in the ancient trade wind belt, and paleomagnetic data imply that 
the Kansas sea was approximately $10^{\circ}$ north of the paleoequator (Heckel, 1979).

\section{Sampling and Analytical Methodology}

Outcrop samples were collected from vertical channels along strike in eastern Kansas (fig. 3). The samples, representing the least weathered rock available, were collected on the basis of lateral and vertical changes in color, fauna, grain size, bedding, and other visible structures and characteristics. Subsurface cores from western and central Kansas (fig. 3), which provide a revealing look at unweathered black shale units, were sampled at appropriate intervals based on the characteristics previously mentioned. The subsurface core samples allow comparison of fresh outcrop samples with unweathered core samples of the same units and thus provide an indication of the amount and nature of weathering. The subsurface core samples also permit examination of the western lateral equivalents of the Forest City Basin sedimentary rocks (fig. 3).
Analytical techniques used in this study include ${ }^{\prime}$-ray fluorescence for major elements and several trace elerronts, analysis of amount of total organic carbon (TOC), and colorimetric determination of acid-soluble iron to provide the DOP parameter. Degree of pyritization provides a quick and reliable quantitative method of characterizing bo+tomwater oxygenation conditions during deposition but, according to Raiswell and others (1988), has several constraints.

1. Appreciable organic carbon must be present ( $>0.15$ percent).

2. Only fresh samples or subsurface core sarples can be used because loss of pyritic sulfur may occur as the result of oxidation reactions.

3. Sufficient clastic materials (that is, iron containing) must be present in the samples. Less than 65 percent skeletal debris is suggested by Raiswell and Borner (1985).

4. Sediments that possess late diagenetic iror-rich concretionary carbonate material should be avoided. Iron migration adds to acid-extractable iron content.
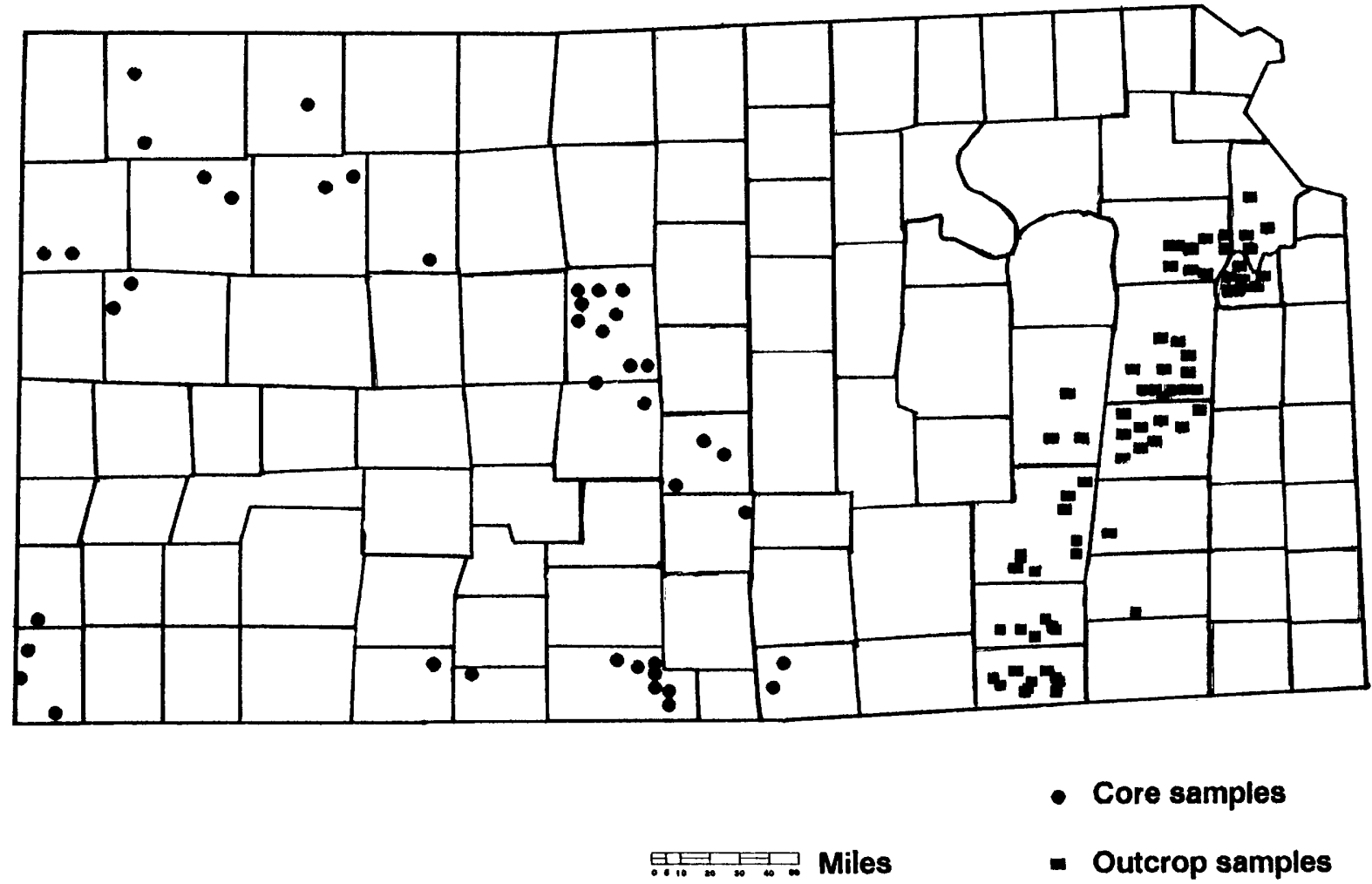

- Core samples

- Outcrop samples

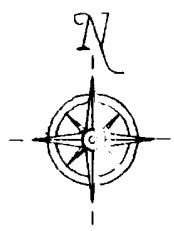

Figure 3. Outcrop (circles) and core (squares) sample localities, Kansas. 
Table 1. Major-element analyses of black shales from the Virgilian of Kansas

[All values in weight percent except $\mathrm{Zn}$, which is in parts per million. Samples designated HB, QH, and LB are Heebner type, those designated SH and HO are Shanghai Creek type. Tr indicates trace]

\begin{tabular}{|c|c|c|c|c|c|c|c|c|c|c|c|c|}
\hline Sample & $\mathrm{SiO}_{2}$ & $\mathrm{TiO}_{2}$ & $\mathrm{Al}_{2} \mathrm{O}_{3}$ & $\mathrm{Fe}_{2} \mathrm{O}_{3}$ & $\mathrm{MnO}_{2}$ & $\mathrm{MgO}$ & $\mathrm{CaO}$ & $\mathrm{Na}_{2} \mathrm{O}$ & $\mathrm{K}_{2} \mathrm{O}$ & $\mathrm{P}_{2} \mathrm{O}_{5}$ & $S$ & $\mathrm{Zn}_{2} \mathrm{O}_{3}$ \\
\hline \multicolumn{13}{|c|}{ OUTCROPSAMPLES } \\
\hline HB1 & 47.58 & 0.72 & 14.44 & 5.70 & 0.032 & 2.21 & 4.09 & 0.72 & 3.38 & 0.87 & 1.19 & 70 \\
\hline HB2 & 55.43 & 0.90 & 16.70 & 6.08 & 0.039 & 2.24 & 0.77 & 0.91 & 3.45 & 0.27 & 0.02 & 68 \\
\hline HB3 & 52.54 & 0.84 & 18.53 & 5.40 & 0.030 & 2.15 & 1.27 & 0.83 & 3.34 & 0.14 & 0.95 & 1,292 \\
\hline HB4 & 50.55 & 0.75 & 18.38 & 4.69 & 0.037 & 1.88 & 4.01 & 0.58 & 3.22 & 0.19 & 0.21 & 883 \\
\hline QH1 & 46.26 & 0.64 & 12.46 & 5.08 & 0.029 & 2.40 & 2.59 & 0.57 & 3.21 & 0.80 & 1.62 & 3,714 \\
\hline $\mathrm{QH} 2$ & 55.01 & 0.88 & 18.02 & 5.31 & 0.029 & 2.39 & 0.67 & 0.92 & 3.74 & 0.16 & 0.01 & 644 \\
\hline QH3 & 45.99 & 0.68 & 12.98 & 4.86 & 0.026 & 1.96 & 3.95 & 0.66 & 3.10 & 0.77 & 0.86 & 1,116 \\
\hline QH4 & 46.31 & 0.70 & 14.43 & 4.99 & 0.031 & 2.56 & 4.77 & 0.80 & 3.25 & 0.56 & 0.78 & 1,035 \\
\hline QH5 & 50.46 & 0.85 & 21.19 & 6.43 & 0.028 & 2.16 & 1.06 & 0.46 & 3.89 & 0.13 & $\mathrm{Tr}$ & 106 \\
\hline QH6 & 52.51 & 0.87 & 18.02 & 5.87 & 0.035 & 2.06 & 1.14 & 0.84 & 3.19 & 0.46 & 0.05 & 2,109 \\
\hline LB1 & 46.16 & 0.81 & 14.83 & 6.40 & 0.027 & 1.94 & 1.68 & 0.56 & 3.50 & 0.39 & 0.88 & 1,196 \\
\hline LB2 & 56.24 & 0.95 & 17.75 & 5.75 & 0.040 & 2.08 & 0.69 & 0.95 & 3.13 & 0.28 & $\operatorname{Tr}$ & 88 \\
\hline LB3 & 44.87 & 0.78 & 14.84 & 6.08 & 0.029 & 2.27 & 1.81 & 0.70 & 3.81 & 0.40 & 1.06 & 1,606 \\
\hline LB4 & 44.21 & 0.78 & 13.98 & 6.87 & 0.025 & 1.99 & 2.00 & 0.62 & 3.35 & 0.28 & 0.69 & 4,393 \\
\hline $\mathrm{HO} 1$ & 50.15 & 0.75 & 16.78 & 5.22 & 0.026 & 2.36 & 3.51 & 1.01 & 3.57 & 0.59 & 0.04 & 789 \\
\hline SH1 & 49.29 & 0.84 & 18.67 & 6.13 & 0.033 & 2.35 & 1.54 & 0.77 & 3.66 & 0.26 & 1.44 & 94 \\
\hline $\mathrm{SH} 2$ & 50.03 & 0.90 & 19.17 & 6.10 & 0.025 & 2.32 & 1.25 & 0.75 & 3.62 & 0.18 & 0.05 & 330 \\
\hline SH3 & 50.59 & 0.90 & 18.69 & 6.54 & 0.049 & 2.37 & 1.50 & 1.17 & 3.34 & 0.47 & 0.03 & 2,155 \\
\hline SH4 & 46.87 & 0.67 & 15.37 & 4.44 & 0.069 & 2.21 & 9.17 & 0.84 & 2.96 & 0.22 & 0.47 & 239 \\
\hline Average & 49.53 & 0.80 & 16.59 & 5.68 & 0.034 & 2.21 & 2.45 & 0.77 & 3.41 & 0.39 & 0.54 & 1154 \\
\hline
\end{tabular}


Table 1. Continued

\begin{tabular}{|c|c|c|c|c|c|c|c|c|c|c|c|c|}
\hline Sample & $\mathrm{SiO}_{2}$ & $\mathrm{TiO}_{2}$ & $\mathrm{Al}_{2} \mathrm{O}_{3}$ & $\mathrm{Fe}_{2} \mathrm{O}_{3}$ & $\mathrm{MnO}_{2}$ & $\mathrm{MgO}$ & $\mathrm{CaO}$ & $\mathrm{Na}_{2} \mathrm{O}$ & $\mathrm{K}_{2} \mathrm{O}$ & $\mathrm{P}_{2} \mathrm{O}_{5}$ & $S$ & $\overline{\mathrm{Zn}_{2} \mathrm{O}_{3}}$ \\
\hline \multicolumn{13}{|c|}{ CORE SAMPLES } \\
\hline$\overline{\mathrm{HBC}-1}$ & 26.86 & 0.16 & 4.37 & 0.65 & 0.022 & 2.46 & 45.77 & 0.61 & 1.76 & 1.00 & 0.20 & 217 \\
\hline HBC-2 & 27.96 & 0.19 & 4.86 & 0.81 & 0.024 & 2.40 & 51.48 & 0.61 & 1.88 & 1.42 & 0.25 & 189 \\
\hline HBC-3 & 25.13 & 0.16 & 4.60 & 0.79 & 0.024 & 2.65 & 39.86 & 0.71 & 1.83 & 1.40 & 0.24 & 173 \\
\hline HBC-4 & 44.18 & 0.42 & 12.01 & 1.93 & 0.020 & 3.37 & 15.76 & 1.06 & 3.65 & 0.32 & 0.16 & 297 \\
\hline HBC-5 & 44.24 & 0.46 & 12.79 & 1.99 & 0.020 & 3.37 & 15.00 & 1.10 & 3.87 & 0.20 & 0.12 & 232 \\
\hline HBC-6 & 33.62 & 0.25 & 8.00 & 1.49 & 0.021 & 2.32 & 23.03 & 0.77 & 2.78 & 0.17 & 0.75 & 279 \\
\hline HBC-7 & 19.91 & 0.12 & 3.60 & 0.52 & 0.019 & 1.29 & 28.49 & 0.34 & 1.58 & 0.14 & 0.16 & $\mathrm{Tr}$ \\
\hline $\mathrm{QHC}-1$ & 49.40 & 0.62 & 14.04 & 4.44 & 0.026 & 3.70 & 5.32 & 1.30 & 3.87 & 0.18 & 1.91 & 91 \\
\hline QHC-2 & 49.18 & 0.64 & 14.22 & 4.68 & 0.026 & 3.72 & 5.35 & 1.28 & 3.92 & 0.16 & 1.99 & 116 \\
\hline QHC-3 & 49.29 & 0.65 & 14.35 & 3.27 & 0.024 & 4.16 & 6.78 & 1.33 & 4.12 & 0.23 & 0.85 & 62 \\
\hline $\mathrm{QHC}-4$ & 46.80 & 0.57 & 13.89 & 2.71 & 0.019 & 4.26 & 5.00 & 1.35 & 4.15 & 0.46 & 0.53 & 62 \\
\hline QHC-5 & 27.19 & 0.21 & 6.07 & 1.74 & 0.032 & 9.76 & 21.34 & 0.96 & 1.83 & 0.30 & 1.64 & 4 \\
\hline QHC-6 & 37.09 & 0.49 & 11.25 & 3.51 & 0.034 & 7.22 & 12.40 & 2.01 & 3.02 & 1.84 & 2.57 & 32 \\
\hline QHC-7 & 43.29 & 0.60 & 12.29 & 3.21 & 0.032 & 6.87 & 9.65 & 1.38 & 3.08 & 0.36 & 1.53 & 48 \\
\hline QHC-8 & 45.27 & 0.66 & 13.35 & 3.50 & 0.030 & 7.51 & 7.63 & 1.56 & 3.19 & 0.49 & 1.76 & 52 \\
\hline QHC-9 & 37.87 & 0.59 & 11.00 & 5.27 & 0.030 & 6.97 & 10.08 & 1.48 & 2.95 & 0.41 & 4.33 & 37 \\
\hline SHC-1 & 39.44 & 0.42 & 11.17 & 2.43 & 0.037 & 2.39 & 18.02 & 1.04 & 2.94 & 0.15 & 0.82 & 22 \\
\hline SHC-2 & 41.65 & 0.48 & 12.36 & 3.08 & 0.048 & 2.93 & 15.07 & 1.07 & 3.14 & 0.17 & 0.65 & 37 \\
\hline SHC-3 & 43.65 & 0.53 & 13.41 & 3.07 & 0.036 & 2.68 & 13.56 & 1.15 & 3.37 & 0.16 & 0.85 & 40 \\
\hline Average & 38.53 & 0.43 & 10.40 & 2.58 & 0.030 & 4.21 & 18.40 & 1.11 & 3.00 & 0.50 & 1.11 & 93 \\
\hline \multicolumn{13}{|c|}{ STANDARDS } \\
\hline$\overline{\text { SDO-1 }}$ & 49.80 & 0.72 & 12.62 & 9.33 & 0.046 & 1.55 & 1.04 & 0.42 & 3.30 & 0.12 & 5.31 & 72 \\
\hline MAG-1 & 51.19 & 0.75 & 16.46 & 6.98 & 0.100 & 3.13 & 1.38 & 3.91 & 3.72 & 0.18 & 0.43 & 135 \\
\hline $\mathrm{SCo}-1$ & 63.39 & 0.62 & 13.70 & 5.22 & 0.050 & 2.76 & 2.64 & 0.95 & 2.82 & 0.22 & 0.07 & 105 \\
\hline SGR-1 & 28.30 & 0.24 & 6.49 & 2.98 & 0.032 & 4.57 & 8.32 & 3.02 & 1.63 & 0.29 & 1.56 & 81 \\
\hline ST -10 & 59.66 & 0.54 & 10.15 & 7.50 & 0.037 & 1.25 & 0.84 & 0.34 & 2.65 & 0.09 & 4.27 & 61 \\
\hline ST-11 & 68.97 & 0.41 & 7.80 & 5.77 & 0.028 & 0.96 & 0.64 & 0.26 & 2.04 & 0.07 & 3.28 & 51 \\
\hline ST -12 & 79.26 & 0.28 & 5.21 & 3.85 & 0.019 & 0.64 & 0.43 & 0.17 & 1.36 & 0.05 & 2.19 & 41 \\
\hline $\mathrm{ST}-13$ & 89.73 & 0.14 & 2.59 & 1.91 & 0.009 & 0.32 & 0.21 & 0.09 & 0.68 & 0.02 & 1.09 & 31 \\
\hline
\end{tabular}


Table 2. Iron, sulfur, and carbon in black shales from the Virgilian of Kansas

[Samples designated HB, QH, and LB are Heebner type, those designated SH and HO are Shanghai Creek type. Sorg (organic sulfur), TOC (total organic carbon), Fe2sol (ferrous iron), FeTsol (ferric iron), FePY (pyrite iron); Spy, pyrite sulfur or nonorganic sulfur. Tr indicates trace]

\begin{tabular}{|c|c|c|c|c|c|c|c|c|c|c|c|c|}
\hline $\begin{array}{l}\text { Sample } \\
\text { number }\end{array}$ & $\% \mathrm{Fe}$ & $\% \mathrm{~S}$ & $\%$ Sorg & $\%$ TOC & $\mathrm{Fe} 2 \mathrm{sol}$ & FeTsol & FePY & Spy & DOP & $\begin{array}{l}\text { Fe2sol } \\
\text { FeTsol }\end{array}$ & $\frac{\mathrm{FeTsol}+\mathrm{FePY}}{\% \mathrm{Fe}}$ & Spy/TOC \\
\hline \multicolumn{13}{|c|}{ OUTCROP SAMPLES } \\
\hline $\mathrm{QH} 1$ & 5.04 & 1.61 & 0.11 & 15.00 & 0.49 & 0.73 & 1.31 & 1.51 & 0.64 & 0.66 & 0.41 & 0.100 \\
\hline $\mathrm{SH} 1$ & 6.13 & 1.44 & 0.03 & 4.74 & 0.98 & 1.45 & 1.23 & 1.41 & 0.46 & 0.67 & 0.44 & 0.297 \\
\hline HB1 & 5.70 & 1.19 & 0.06 & 8.80 & 0.70 & 1.44 & 0.98 & 1.13 & 0.41 & 0.49 & 0.43 & 0.128 \\
\hline LB3 & 6.08 & 1.06 & 0.11 & 16.12 & 0.69 & 1.28 & 0.83 & 0.95 & 0.39 & 0.54 & 0.36 & 0.059 \\
\hline HB3 & 5.40 & 0.95 & 0.02 & 2.18 & 0.78 & 1.32 & 0.81 & 0.93 & 0.38 & 0.59 & 0.40 & 0.429 \\
\hline QH3 & 4.86 & 0.86 & 0.11 & 16.37 & 0.64 & 1.18 & 0.65 & 0.75 & 0.36 & 0.54 & 0.40 & 0.046 \\
\hline $\mathrm{QH} 4$ & 4.99 & 0.78 & 0.08 & 11.19 & 0.87 & 1.30 & 0.61 & 0.70 & 0.32 & 0.67 & 0.39 & 0.063 \\
\hline LB1 & 6.40 & 0.88 & 0.11 & 15.23 & 0.81 & 1.75 & 0.67 & 0.77 & 0.28 & 0.46 & 0.39 & 0.051 \\
\hline $\mathrm{SH} 4$ & 4.44 & 0.47 & 0.01 & 1.40 & 1.03 & 1.58 & 0.40 & 0.46 & 0.20 & 0.65 & 0.45 & 0.329 \\
\hline LB4 & 6.87 & 0.67 & 0.13 & 18.41 & 0.89 & 2.09 & 0.47 & 0.54 & 0.18 & 0.43 & 0.39 & 0.030 \\
\hline HB4 & 4.69 & 0.21 & 0.03 & 3.58 & 0.71 & 1.56 & 0.16 & 0.18 & 0.09 & 0.45 & 0.38 & 0.052 \\
\hline QH6 & 5.87 & 0.05 & 0.02 & 2.28 & 1.22 & 2.59 & 0.03 & 0.03 & 0.01 & 0.47 & 0.46 & 0.015 \\
\hline HO1 & 5.22 & 0.04 & 0.01 & 2.06 & 0.44 & 1.96 & 0.02 & 0.03 & 0.01 & 0.23 & 0.39 & 0.012 \\
\hline $\mathrm{SH} 2$ & 6.10 & 0.05 & 0.03 & 3.72 & 0.55 & 1.93 & 0.02 & 0.02 & 0.01 & 0.29 & 0.33 & 0.006 \\
\hline SH3 & 6.54 & 0.03 & 0.02 & 2.52 & 0.96 & 2.47 & 0.01 & 0.01 & 0.00 & 0.39 & 0.39 & 0.005 \\
\hline $\mathrm{QH} 2$ & 5.31 & 0.01 & 0.01 & 1.00 & 0.81 & 1.57 & 0 & 0 & 0 & 0.52 & 0.30 & 0.003 \\
\hline QH5 & 6.43 & $\operatorname{Tr}$ & 0.00 & 0.27 & 0.25 & 2.49 & 0 & 0 & 0 & 0.10 & 0.39 & 0 \\
\hline LB2 & 5.75 & $\mathrm{Tr}$ & 0.00 & 0.06 & 0.19 & 2.61 & 0 & 0 & 0 & 0.07 & 0.61 & 0 \\
\hline Average & 5.68 & 0.54 & 0.05 & 6.62 & 0.70 & 1.70 & 0.43 & 0.49 & 0.20 & 0.41 & 0.40 & 0.075 \\
\hline
\end{tabular}


Table 2. Continued

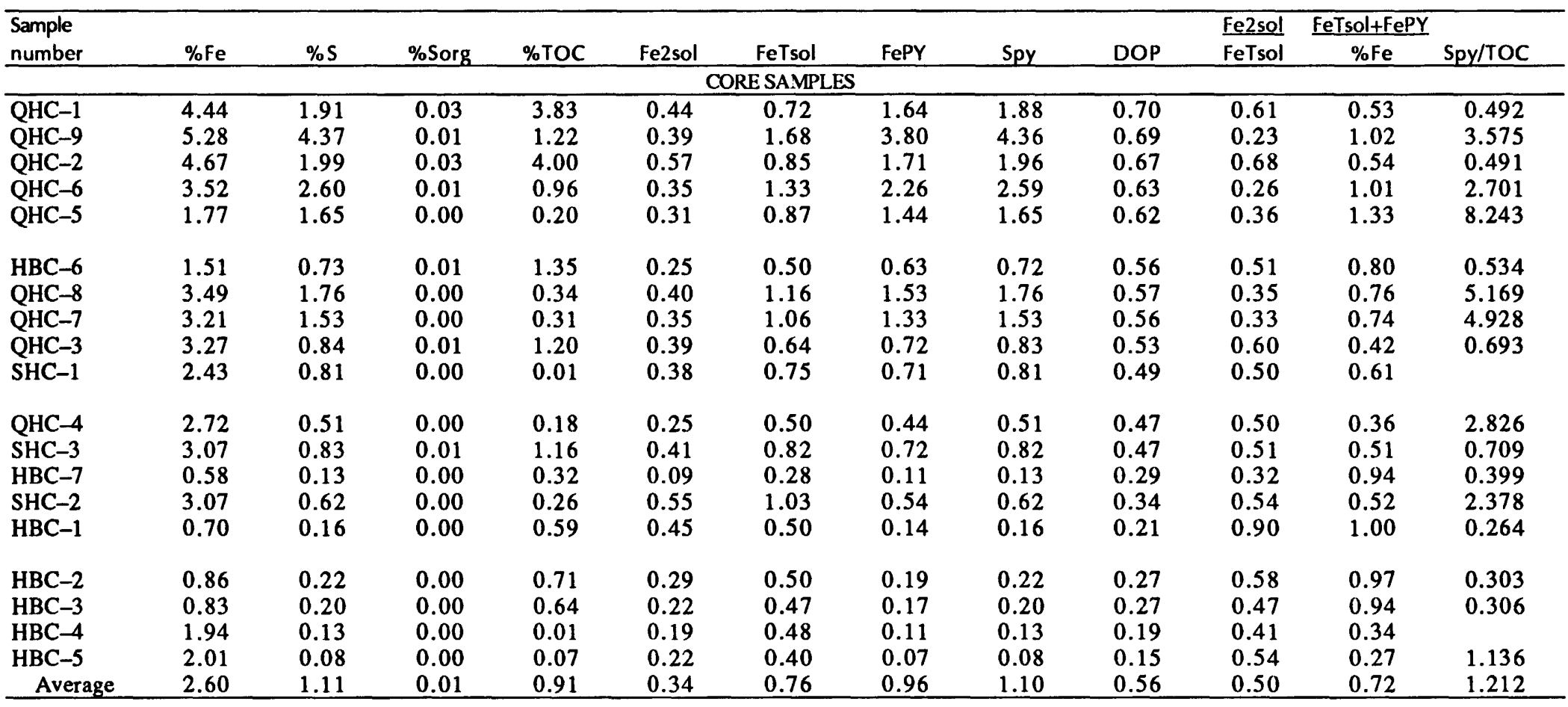




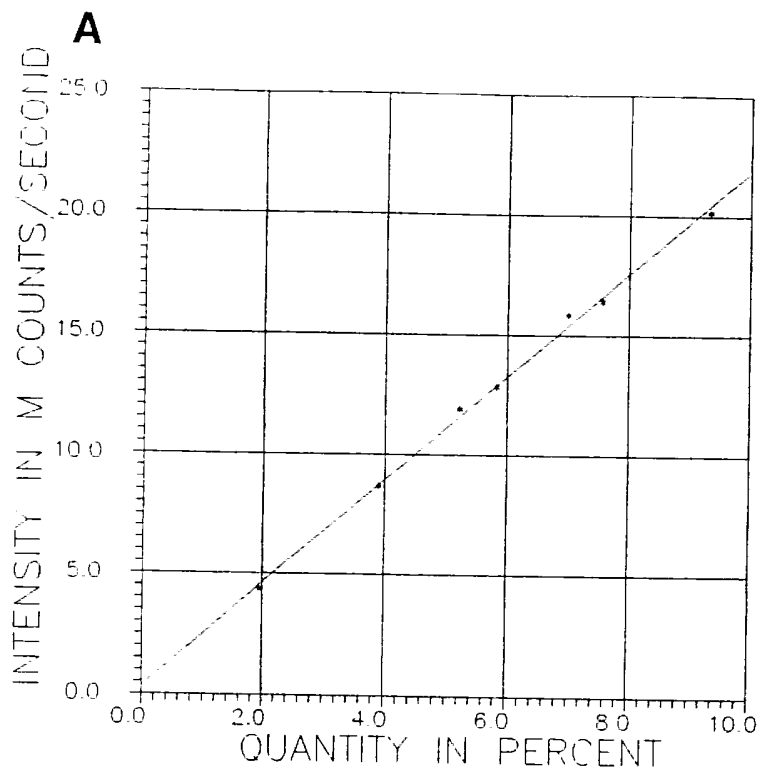

Calibration curve for XRF regression analysis of iron standards

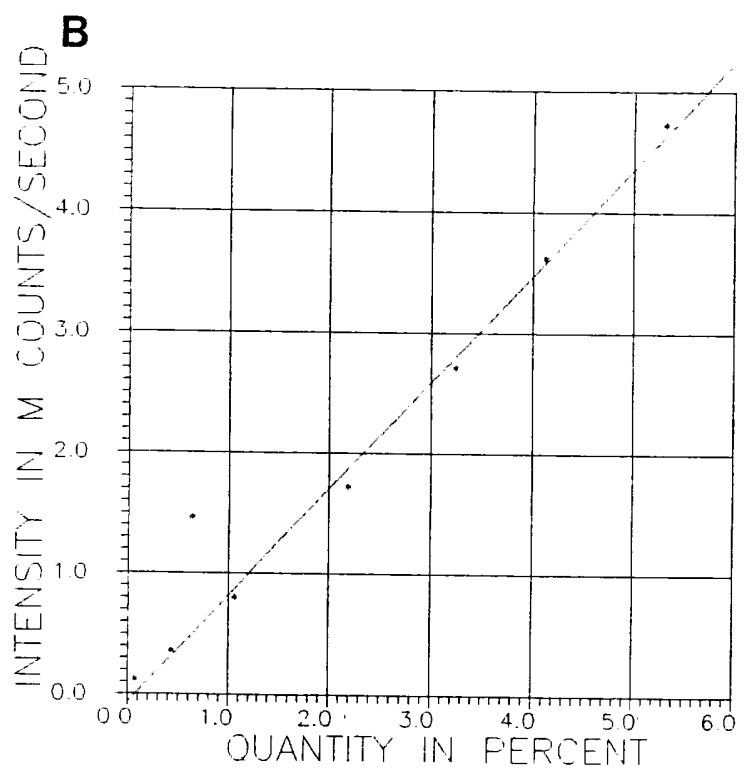

Calibration curve for XRF regression analysis of sulfur standards.

Figure 4. Calibration curves for XRF regression analyses. $A$, Iron standards. $B$, Sulfur standards.

\section{Analytical Techniques}

The equipment employed for the X-ray fluorescence analysis consisted of a wavelength-dispersive Rigaku System $3070 \mathrm{X}$-ray spectrometer. Samples were initially ground in a shatterbox for 5-7 minutes (or until approximately $400 \mathrm{mesh}$ ). Samples were not sieved in order to avoid preferential mineralogical effects. The resulting powder was then pressed into a pellet usin 20 tons of pressure. The base of the pellets consists of mi-rocrystalline cellulose, which allows for ease of handling and chemical stability and provides a nonreactive, seminonporous medium. Sample analyses were repeated three times each on the Rigaku System for major element oxide weight percent. It was essential that iron and sulfur analyses $h \cdot 9$ accurate in order for the DOP determinations to be precire.

Each sample in this study was analyzed for $\mathrm{Si}, \mathrm{Ti}, \mathrm{Al}$, $\mathrm{Fe}, \mathrm{Mn}, \mathrm{Mg}, \mathrm{Ca}, \mathrm{Na}, \mathrm{K}, \mathrm{P}$, and $\mathrm{S}$ (table 1). Calibration curves for each element were generated using several geochemical standards including MQSB-1, SDO-1, MAG-1, SCo-1, and SGR-1. The calibration curves for iron and sulfur are depicted on figure 4.

Analysis of total organic carbon (TOC was accomplished by using a Perkin-Elmer Model 240 Elemental Analyzer and SDO-1 as a standard. Samples were crushed and analyzed for total carbon, then treated with concentrated $\mathrm{HCl}$ to remove carbonate carbon. Residue from the acid treatment was analyzed for total organic cerbon content (TOC).

In addition to the analysis for TOC, a colorimetric determination for acid-soluble iron was conducted on powder samples to satisfy the equation for DOP (Raiswell and Berner, 1985):

$$
\mathrm{DOP}=\mathrm{Pyrite} \text { iron/(HCl-extractable iron+pyrite iron) }
$$

Acid-extractable iron was obtained by boiling each sample in concentrated $\mathrm{HCl}$ for precisely 1 minute on a hot plate (Berner, 1970). This treatment extracts the most reactive iron compounds and is readily reproducible. Dissolved iron was determined by the 1,10 phenanthroline colorimetric method using a Beckman Model DU-2 spectrophotometer (Liu, 1988). Both total and ferrous acidsoluble iron were measured.

The colorimetric method is based on the principle that "reactive" iron is dissolved into solution by boiling with $\mathrm{HCl}$ and then complexed with 1,10 phenantr oline at $\mathrm{pH}$ values of 3.2-3.3. The orange-red complex that results obeys Beer's Law where its intensity is indep?ndent of $\mathrm{pH}$ (3-9) and is stable for a substantial amount of time. The phenanthroline reacts only with ferrous iron; ferric iron is determined by reduction using hydroxylamine hydrochloride followed by the phenanthroline recction. Pyrite iron was estimated by assuming that all sulfur is present as pyrite or organic sulfur. Organic sulfur was estimated from organic carbon by using ratios determined by' Kaplan and others (1963) for Santa Barbara Basin sediments. Because some sulfur may also be present as sulfate, th is procedure provides a maximum value for pyrite iron and thus for DOP. 


\section{RESULTS AND TYPES OF BLACK SHALES IN THE KANSAS SECTION}

Based on geochemical parameters, including pyrite iron, total sulfur content, acid-extractable iron, and DOP, two types of black shales are present in the Virgilian of Kansas (table 2). Results for outcrop samples differ slightly from results for core samples. Core samples generally contain less total iron and more calcium and sulfur.

Maximum DOP was calculated using equation (1) and by assuming stoichiometric iron in pyrite calculated from total sulfur content corrected for organic sulfur. Raiswell and others (1988) defined depositional environmental conditions based on DOP values and concluded that DOP values of less than 0.45 indicate aerobic bottom-water conditions, values between 0.45 and 0.75 define restricted bottom-water conditions, and values greater than 0.75 reflect inhospitable bottom-water conditions. Based on this classification scheme, Heebner-type units and Shanghai Creek-type units of the Kansas Virgilian differ dramatically.

\section{Heebner-Type Black Shales}

Heebner-type black shales, as coined by Coveney (1985), include the Heebner Shale Member of the Oread Limestone, Queen Hill Shale Member of the Lecompton Limestone, and Larsh Shale and Burroak Shale Members of the Deer Creek Limestone (fig. 1). From a geochemical perspective, the Heebner types contain more total sulfur (mean $=0.75$ percent) than the Shanghai Creek types (mean=0.10 percent), undoubtedly the result of differing depositional settings for the two units. DOP values (mean=0.55) are also greater for the Heebner-type restricted conditions.

\section{Shanghai Creek-Type Black Shales}

Shanghai Creek-type black shales, named for the Shanghai Creek Shale Member of Merriam (1989) include the prototype Shanghai Creek Shale Member of the Howard Limestone and the Holt Shale Member of the Topeka Limestone (fig. 1). Characterized by their lower total sulfur content, acid-extractable iron content, and DOP values, the Shanghai-type black shales were probably deposited in shallower water than the Heebner-type rocks and thus could accommodate organic material not associated with the Heebner-type rocks. DOP values are considerably lower (mean $=0.15$ ) and are consistent with aerobic conditions as defined by Raiswell and others (1988).

\section{CONCLUSIONS}

Black shales, commonly metal rich, make up distinct members of repetitive sequences in the Virgilian of Kansas.
Five black shale members were analyzed for various geochemical parameters including acid-extractable iron content and major-element contents. Based on these and other geochemical and sedimentological characteristics, two types of black shales are present in the Virgilian of Kansas: the Heebner and the Shanghai Creek. Degree of pyritization (DOP) was used to infer bottom-water oxygenation conditions during deposition. DOP values for Heebner-type deposits are, on average, 0.55 (restricted conditions), whereas DOP values for Shanghai Creek-type units are 0.10 (aerobic conditions).

Acknowledgments.-The author would like to thank Dr. D.F. Merriam for offering helpful suggestions, ed iting the manuscript, and stimulating interest in the project. Additionally, thanks go to Dr. R.M. Coveney and Dr. H.L.O. Huyck for their helpful suggestions. Numerous discussions with Dr. Huyck greatly improved the manuscript. Core samples were provided with the help of Dr. W.L. Watney and the Kansas Geological Surver in Lawrence, Kansas. This project represents research for part of a doctoral thesis funded in part by a Grant-in-Aid from Sigma Xi and a Research Grant from the Geological Scciety of America (4547-90).

\section{REFERENCES CITED}

Berner, R.A., 1970, Sedimentary pyrite formation: American Journal of Science, v. 268, p. 1-23.

Coveney, R.M., Jr., 1985, Temporal and spatial variations in Pennsylvanian black shale geochemistry, in Watney, W.L., Kaesler, R.L., and Newell, K.D., eds., Proceedings Fecent Interpretations of Late Paleozoic cyclothems: Law:ence, Kansas, Kansas Geological Survey, p. 247-266.

Coveney, R.M., Jr., and Glascock, M.D., 1989, A review of the origins and metal-rich Pennsylvanian black shales, central U.S.A., with an inferred role for basinal brines: Applied Geochemistry, v. 4, no. 4, p. 342-367.

Cubitt, J.M., 1975, A computer analysis of the geochemistry and mineralogy together with the petrology of the Upper Pennsylvanian and Lower Permian shales of Kansas, U.S.A.: England, University of Leicester, Ph.D. thesis, $366 \mathrm{p}$.

1979, The geochemistry, mineralogy, and petrolory of Upper Paleozoic shales of Kansas: Kansas Geological Survey Bulletin Number 217, 117 p.

Heckel, P.H., 1972, Pennsylvanian stratigraphic reefs in Kansas, some modern comparisons and implications: Geologische Rundschau, v. 61, no. 2, p. 584-598.

1977, Origin of phosphatic black shale facies in Pennsylvanian cyclothems of Mid-Continent North America: American Association Petroleum Geolology Bulletin, v. 61, no. 4, p. 1045-1068.

Heckel, P.H., and others, 1979, Field guide to Pennsylvanian cyclic deposits of Kansas and Nebraska: Kansas Geol ?gical Survey Guidebook Series 4, p. 4-60.

Kaplan, I.R., Emery, K.O., and Rittenberg, S.C., 1963. The distribution and isotopic abundance of sulphur in recent 
marine sediments off southern California: Geochimica et Cosmochimica Acta, v. 27, p. 297-331.

Liu, T., 1988, C-S-Fe correlation of shales hosting sedimentary manganese deposits: Ohio, University of Cincinnati, Ph.D. thesis, $300 \mathrm{p}$.

Merriam, D.F., 1963, The geologic history of Kansas: Kansas Geological Survey Bulletin 162, 317 p.

1986, Geology of the Shawnee Group (Virgilian Stage, Upper Pennsylvanian) in eastern Kansas and its relation to the cyclothem theory, in Merriam, D.F., ed., Stratigraphic, sedimentologic, and cyclic relationships of the Shawnee Group (Virgilian, Pennsylvanian) in eastern Kansas: Kansas Geological Society Annual Field Conference, 38th, Guidebook, p. 1-52.

1989, The Wauneta Limestone, a new member of the Howard Limestone (Wabaunsee Group, Upper Pennsylvanian) in eastern Kansas: Kansas Academy of Science Transactions, v. 92, nos. 1-2, p. 107-112.

Raiswell, R., and Berner, R.A., 1985, Pyrite formation in euxinic and semi-euxinic sediments: American Journal of Science, v. 285 , p. $710-724$.

Raiswell, R., Buckley, F., Berner, R.A., and Anderson, T.F., 1988, Degree of pyritization of iron as a paloeonvironmental indicator of bottom-water oxygenation: Jorırnal of Sedimentary Petrology, v. 58, no. 5, p. 812-819.

Schultz, R.B., 1987, Mineral determination of the Heebner Shale Member (Shawnee Group, Upper Pennsylvanian) in southeastern Kansas X-ray diffraction techniques: The Compass, v. 64 , no. 3 , p. $149-159$.

Shaw, A.B., 1964, Time in stratigraphy: New York, McGraw-Hill, $365 \mathrm{p}$.

Vail, P.R., Mitchum, R.M., and Thompson, S., III, 1977, Seismic stratigraphy and global changes of sea level, pt. 4-Global cycles of relative changes of sea level, in Pa!'ton, C.E., ed., Seismic stratigraphy to hydrocarbon deposition: American Association of Petroleum Geology Memoir 26, p. 83-98.

Walper, J.L., and Rowett, C.L., 1973, Plate tectonic and origin of Carribean Sea and Gulf of Mexico: Oklahoma Geologic Notes, v. 33, no. 1, p. 21-22.

Wanless, H. R., 1972, Eustatic shifts in sea level during the deposition of Late Paleozoic sediments in the Central United States, in Elam, J.G., and Chuber, S.P . eds., Cyclic sedimentation in the Permian Basin: West Teras Geological Society, p. 41-54.

Zeller, D.E., ed., 1968, The stratigraphic succession in Kansas: Kansas Geological Survey Bulletin 189, 81 p. 


\section{MEMBERSHIP OF THE U.S. WORKING GROUP OF INTERNATIONAL GEOLOGICAL CORRELATION PROGRAM PROJECT 254}

Roger Ames

AMOCO

P.O. Box 3385

Tulsa, Oklahoma 74101

Belinda Arbogast

U.S. Geological Survey

MS 973 Denver Federal Center

P.O. Box 25046

Denver, Colorado 80225

Michael A. Arthur

University of Rhode Island, Graduate School of Oceanography, Narragansett Bay Campus

Narragansett, Rhode Island 02882-1197

Lance S. Barron

Kentucky Energy Cahinet Laboratory

P.O. Box 13015 Iron Works Pike

Lexington, Kentucky 40512-3015

Joy Beier

Biogeochemical Laboratories

Indiana University

Bloomington, Indiana 47401

Pieter Berendsen

Kansas Geological Survey

University of Kansas, Campus West

Lawrence, Kansas 66045

Merwin Berstein

Berstein Y Thomson Ltda.

Casilla 13806

Santiago, Chile 2228807
William B.N. Berry

University of California, Berkeley

Department of Paleontology, Marine Sciences Group

Berkeley, California 94720

Robert Blair

Couer d'Alene Mines

P.O. Box 2066

Couer d'Alene, Idaho 83814

Edward Bloomstein

Santa Fe Pacific Mining Corporation

6200 Uptown Blvd. NE, Suite 400

Box 27019

Albuquerque, New Mexico 87125-7019

George N. Breit

U.S. Geological Survey

MS 913 Denver Federal Center

P.O. Box 25046

Denver, Colorado 80225

Alex Brown

Department de Genie Mineral

Ecole Polytechnique

P.O. Box 6079, Sta. "A"

Montreal, Quebec H3C 3A7 Canada

William F. Cannon

U.S. Geological Survey

MS 954 National Center

Reston, Virginia 22092 
Chen-Lin Chou

Illinois State Geological Survey

Natural Resources Building

615 E. Peabody Drive

Champaign, Illinois 61820

Sandra H.B. Clark

U.S. Geological Survey

MS 954 National Center

Reston, Virginia 22092

George P. Cole

Cominco American Resources Inc.

831 E. Glendale Avenue

Sparks, Nevada 89431

Raymond M. Coveney

University of Missouri-Kansas City

Department of Geosciences

Kansas City, Missouri 64110-2499

Jeremy Dahl

University of California, Los Angeles

Department of Earth Sciences

Los Angeles, Califoria 90024

Walter E. Dean, Jr.

U.S. Geological Survey

MS 939 Denver Federal Center

P.O. Box 25046

Denver, Colorado 80225

George Desborough

U.S. Geological Survey

MS 905 Denver Federal Center

P.O. Box 25046

Denver, Colorado 80225

Albert B. Dickas

University of Wisconsin-Superior

Grants and Special Programs

Superior, Wisconsin 54880

Clinton S. Ferris, Jr.

Reserve Industries Corp.

9555 Ralston Rd.

Arvada, Colorado 80002
Eric R. Force

U.S. Geological Survey

2255 North Gemini Drive

Flagstaff, Arizona 86001

John D. Forrester

Phelps Dodge Corp.

Western Exploration Office

P.O. Box 50427

Tucson, Arizona 85703-1427

Cary Foulk

808-D Wilshire Blvd.

Metairie, Louisiana 70005

Robert N. Ginsburg

University of Miami

Fisher Island

Miami Beach, Florida 33139

Thomas H. Giordano

New Mexico State University

Department of Earth Sciences

Box $3 \mathrm{AB}$

Las Cruces, New Mexico 88003

Holly J. Glaser

Department of Geological Sciences

Case Western Reserve University

University Circle

Cleveland, Ohio 44118

Robert W. Gloyn

Department of Natural Resources

Utah Geological and Mineral Survey

606 Black Hawk Way

Salt Lake City, Utah 84108-1280

Martin B. Goldhaber

U.S. Geological Survey

MS 973 Denver Federal Center

P.O. Box 25046

Denver, Colorado 80225

Pamela Gore

DeKalb College

Science Department

555 North Indian Creek Drive

Clarkston, Georgia 30021 
Richard I. Grauch

U.S. Geological Survey

MS 973 Denver Federal Center

P.O. Box 25046

Denver, Colorado 80225

Milton C. Graves

Cuesta Research Ltd.

154 Victoria Road

Dartmouth, Nova Scotia B3A 1V8 Canada

Gayanta Guha

Sciences de la Terra

University of Quebec

Chicoutimi, Quebec G7H 2B1 Canada

Richard Hagni

University of Missouri-Rolla

Department of Geology

Rolla, Missouri 65401

Dick Hammond

South Dakota Geological Survey

U.S.D. Science Center

Vermillion, South Dakota 57069

P.E. Hare

Geophysical Laboratory

2801 Upton Street NW

Washington, DC 20008

Joe Hatch

U.S. Geological Survey

MS 977 Denver Federal Center

P.O. Box 25046

Denver, Colorado 80225

Eileen S. Ho

Department of Geological Sciences

University of Michigan

Ann Arbor, Michigan 48109-1063

Rudolf Holl

Institut fur Allgemeine und Angewandte

Geologie der Universitat

Luisenstrasse 37

D-8000 Munchen 2 Federal Republic of Germany
Heinrich D. Holland

Department of Earth and Planetary Sciences

Harvard University

24 Oxford Street

Cambridge, MA 02138

Holly L.O. Huyck

University of Cincinnati

Department of Geology

Mail Location 13

Cincinnati, Ohio 45221

E. Craig Jowett

University of Waterloo

Department of Earth Sciences

Waterloo, Ontario N2L 3G1 Canada

Gale Knutsen

Geology Department

Newmont Gold Co.

P.O. Box 669

Carlin, Nevada 89822

Mike Lambert

Kansas Geological Survey

1930 Constant Ave. Campus West

University of Kansas

Lawrence, Kansas 66046

Joel Leventhal

U.S. Geological Survey

MS 973 Denver Federal Center

P.O. Box 25046

Denver, Colorado 80225

Michael D. Lewan

AMOCO Production Co.

Research Center

P.O. Box 3386

Tulsa, Oklahoma 74102

David A. Lindsey

U.S. Geological Survey

MS 905 Denver Federal Center

P.O. Box 25046

Denver, Colorado 80225

Timothy W. Lyons

Yale University

Department of Geology and Geophysics

P.O. Box 6666

New Haven, Connecticut 06511 
Edwin K. Maughn

U.S. Geological Survey

MS 973 Denver Federal Center

P.O. Box 25046

Denver, Colorado 80225

\section{J. Barry Maynard}

Department of Geology

University of Cincinnati

Cincinnati, Ohio 45221-0013

Phillip A. Meyers

University of Michigan

Dept. of Atmospheric and Oceanic Sciences

Ann Arbor, Michigan 48109

James Murowchick

University of Missouri-Kansas City

Department of Geosciences

Kansas City, Missouri 64110-2499

Bartholomew S. Nagy

University of Arizona

Department of Geosciences

520 Gould-Simpson Building

Tucson, Arizona 85721

Carl E. Nelson

7500 E. Quincy C-203

Denver, Colorado 80237

Laurence M. Nuelle

Missouri Department of Natural Resources

Div. of Geology and Land Survey

P.O. Box 250

Rolla, Missouri 65401-0250

Suzanne O'Connell

Ocean Drilling Program

Texas A\&M University Research Park

1000 Discovery Drive

College Station, Texas 77840

Patrick M. Okita

U.S. Geological Survey

MS 954 National Center

12201 Sunrise Valley Drive

Reston, Virginia 22052
Robert H. Parker

Coastal Eco Systems Management, Inc.

120 N. Rupert Street

Fort Worth, Texas 76107

F.G. Poole

U.S. Geological Survey

MS 905 Denver Federal Center

P.O. Box 25046

Denver, Colorado 80225

Mary S. Quinby-Hunt

University of California, Berkeley

Department of Paleontology

Marine Sciences Group

Berkeley, California 94720

Thomas L. Robl

Kentucky Energy Cabinet Laboratory

P.O. Box 13015

Iron Works Pike

Lexington, Kentucky 40512-3015

Robert B. Sanders

Sanders Resource Associates, Inc.

11661 Rockridge Drive

Anchorage, Alaska 99516

Jeanine Schmidt

U.S. Geological Survey

4200 University Drive

Anchorage, Alaska 99508

Aloysio A. de Senna Filho

PETROMISA

Av. Presidente Vargas 583/s-1909

20071 Rio de Janeiro RJ Brazil

Nelson R. Shaffer

Indiana Geological Survey

611 North Walnut Grove

Bloomington, Indiana 47401

Patricia Sheahan

Konsult International Inc.

44 Gemini Road

Willowdale, Ontario M2K 2G6 Canada 
Kevin Shelton

University of Missouri-Columbia

Department of Geology

Columbia, Missouri 65211

D.A. Spears

University of Sheffield

Department of Geology

Mappin Street

Sheffield S1 3JD England

Nur Iskandar Taib

Indiana University

Department of Geology

Bloomington, Indiana 47405

John Trammell

2040 Barberry Ave.

Grand Junction, Colorado 81506

Franklyn B. Van Houten

Princeton University

Department of Geological and Geophysical Sciences

Guyot Hall

Princeton, New Jersey 08544

Kenneth C. Watts

U.S. Geological Survey

MS 973 Denver Federal Center

P.O. Box 25046

Denver, Colorado 80225
Gene C. Whitney

U.S. Geological Survey

MS 904 Denver Federal Center

P.O. Box 25046

Denver, Colorado 80225

Pat Wilde

University of California, Berkeley

Department of Paleontology

Marine Sciences Group

Berkeley, California 94720

John C. Wilson

Applied Resources Ltd.

P.O. Box 10894

Denver, Colorado 80210

Sherwood W. Wise Jr.

Florida State University

Departments of Geology and Oceanography

Tallahassee, Florida 32306

Elizabeth Brenner Younggren

P.O. Box 470

Dillon, Montana 59725

Marcos Zentilli

Department of Geology

Dalhousie University

Halifax, Nova Scotia B3H 3J5 Canada 



\section{AUTHOR INDEX}

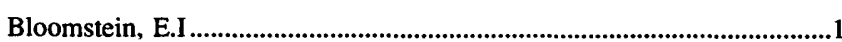

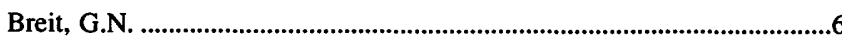

Chen Nansheng.......................................................................................9

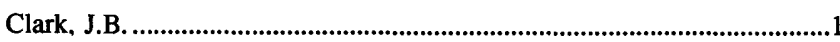

Coveney, R.M., Jr..............................................................................9

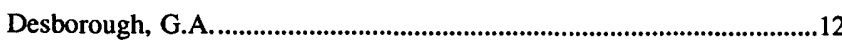

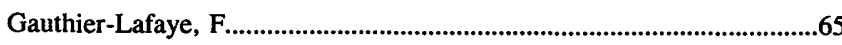

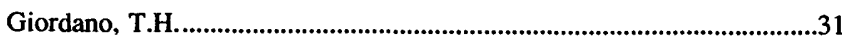

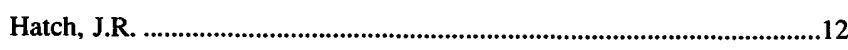

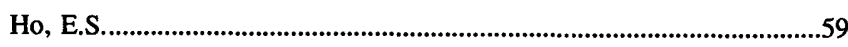

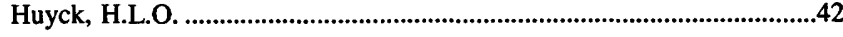

Leventhal, J.S..............................................................................12, 65

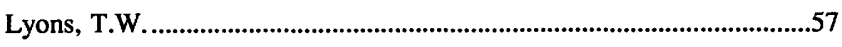

Mauk, J.L..............................................................................................5

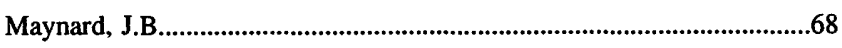

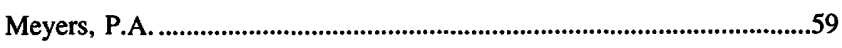

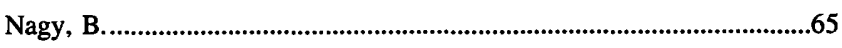

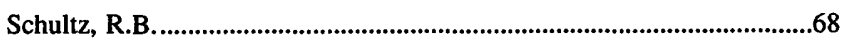

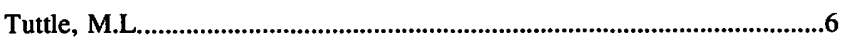

Wanty, R.B. 





\section{SELECTED SERIES OF U.S. GEOLOGICAL SURVEY PUBLICATIONS}

\section{Periodicals}

Earthquakes \& Volcanoes (issued bimonthly).

Prellminary Determination of Epicenters (issued monthly).

\section{Technical Books and Reports}

Professional Papers are mainly comprehensive scientific reports of wide and lasting interest and importance to professional scientists and engineers. Included are reports on the results of resource studies and of topographic, hydrologic, and geologic investigations. They also include collections of related papers addressing different aspects of a single scientific topic.

Bulletins contain significant data and interpretations that are of lasting scientific interest but are generally more limited in scope or geographic coverage than Professional Papers. They include the results of resource studies and of geologic and topographic investigations; as well as collections of short papers related to a specific topic.

Water-Supply Papers are comprehensive reports that present significant interpretive results of hydrologic investigations of wide interest to professional geologists, hydrologists, and engineers. The series covers investigations in all phases of hydrology, including hydrogeology, availability of water, quality of water, and use of water.

Circulars present administrative information or important scientific information of wide popular interest in a format designed for distribution at no cost to the public. Information is usually of short-term interest.

Water-Resources Investigations Reports are papers of an interpretive nature made available to the public outside the formal USGS publications series. Copies are reproduced on request unlike formal USGS publications, and they are also available for public inspection at depositories indicated in USGS catalogs.

Open-File Reports include unpublished manuscript reports, maps, and other material that are made available for public consultation at depositories. They are a nonpermanent form of publication that may be cited in other publications as sources of information.

\section{Maps}

Geologlc Quadrangle Maps are multicolor geologic maps on topographic bases in $71 / 2$ - or 15-minute quadrangle formats (scales mainly 1:24,000 or 1:62,500) showing bedrock, surficial, or engineering geology. Maps generally include brief texts; some maps include structure and columnar sections only.

Geophysical Investigations Maps are on topographic or planimetric bases at various scales; they show results of surveys using geophysical techniques, such as gravity, magnetic, seismic, or radioactivity, which reflect subsurface structures that are of economic or geologic significance. Many maps include correlations with the geology.

Miscellaneous Investigations Series Maps are on planimetric or topographic bases of regular and irregular areas at various scales; they present a wide variety of format and subject matter. The series also includes $71 / 2$-minute quadrangle photogeologic maps on planimetric bases which show geology as interpreted from aerial photographs. Series also includes maps of Mars and the Moon.
Coal Investigations Maps are geologic maps on tonographic or planimetric bases at various scales showing bedrock or s'rficial geology, stratigraphy, and structural relations in certain coal-re-nurce areas.

Oil and Gas Investigations Charts show stratigraphic information for certain oil and gas fields and other areas having petrole ' $m$ potential.

Miscellaneous Field Studies Maps are multicolor or black-andwhite maps on topographic or planimetric bases on quartrangle or irregular areas at various scales. Pre-1971 maps show bed-xck geology in relation to specific mining or mineral-deposit problems: post-1971 maps are primarily black-and-white maps on various sut jects such as environmental studies or wildemess mineral investigation $\varsigma$.

Hydrologic Investigations Atlases are multicolored or black-andwhite maps on topographic or planimetric bases presenting a wide range of geohydrologic data of both regular and irregular areas; p incipal scale is $1: 24,000$ and regional studies are at $1: 250,000$ scale or smaller.

\section{Catalogs}

Permanent catalogs, as well as some others, giving comprehensive listings of U.S. Geological Survey publications are av ilable under the conditions indicated below from the U.S. Geological Survey, Books and Open-File Reports Section, Federal Center, Box 25125, Denver, CO 80225. (See latest Price and Availability List.)

"Publications of the Geological Survey, 1879- 1961" may be purchased by mail and over the counter in paperback book $f r m$ and as a set of microfiche.

"Publications of the Geological Survey, 1962- 1970" may be purchased by mail and over the counter in paperback book f $\sim \mathrm{rm}$ and as a set of microfiche.

"Publications of the U.S. Geological Survey, 1971- 1981" may be purchased by mail and over the counter in paperback bock form (two volumes, publications listing and index) and as a set of mi rofiche.

Supplements for 1982, 1983, 1984, 1985, 1986, and fo- subsequent years since the last permanent catalog may be purchased by mail and over the counter in paperback book form.

State catalogs, "List of U.S. Geological Survey Geologic and Water-Supply Reports and Maps For (State)," may be purch ased by mail and over the counter in paperback booklet form only

"Price and Avallability List of U.S. Geological Survyy Publicatlons," issued annually, is available free of charge in paperback booklet form only.

Selected coples of a monthly catalog "New Publications of the U.S. Geological Survey" av ailable free of charge by mail or may be obtained over the counter in paperback booklet form only. Those wishing a free subscription to the monthly catalog "New Publications of the U.S. Geological Survey" should write to the U.S. Geological Survey, 582 National Center, Reston, VA 22092.

Note.-Prices of Government publications listed in older catalogs, announcements, and publications may be incorrect. Th orefore, the prices charged may differ from the prices in catalogs, annenncements, and publications. 
